\title{
U.PORTO
}

INSTITUTO DE CIÊNCIAS BIOMÉDICAS ABEL SALAZAR

\section{STRUCTURAL AND EXPRESSION CHANGES OF SEPTINS IN MYELOID NEOPLASIA}

\author{
NUNO CERVEIRA
}

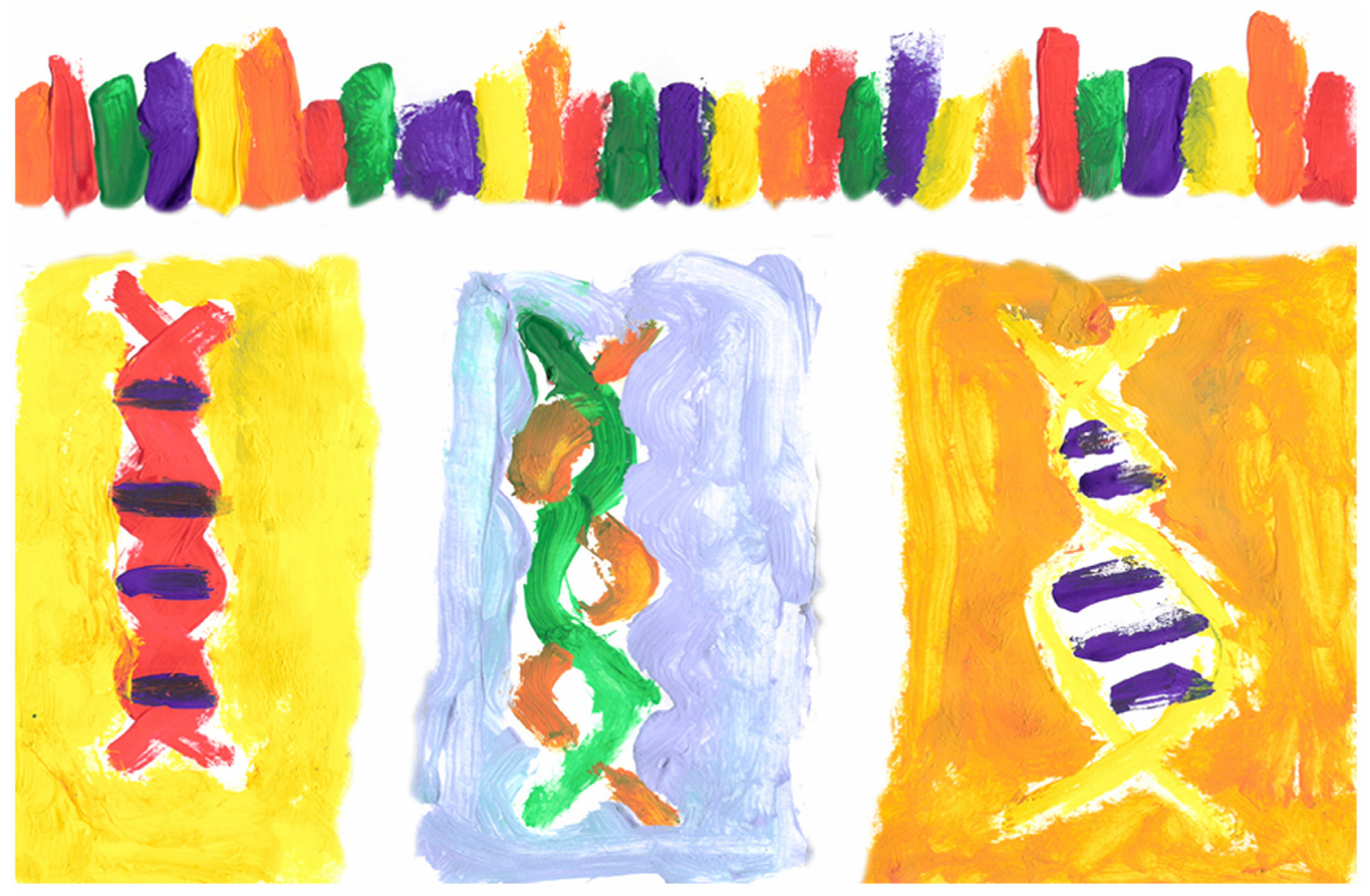

Dissertação de Doutoramento em Ciências Biomédicas 
NUNO MANUEL BOTELHO GONÇALVES SAMPAIO CERVEIRA

STRUCTURAL AND EXPRESSION CHANGES OF SEPTINS IN MYELOID NEOPLASIA

Dissertação de Candidatura ao grau de Doutor em Ciências Biomédicas submetida ao Instituto de Ciências Biomédicas de Abel Salazar da Universidade do Porto 

"Is all that we see or seem but a dream within a dream?"

Edgar Allan Poe

"Imagination will often carry us to worlds that never were. But without it we go nowhere."

Carl Sagan

"Somewhere, something incredible is waiting to be known."

Carl Sagan

This Thesis is dedicated to Sofia and Diogo for all their love and fondness, and for all that they teach me every day.

In the vastness of space and the immensity of time, it is a joy and a pleasure to share a planet and an epoch with you. 



\section{TABLE OF CONTENTS}

$\begin{array}{lr}\text { PREFÁCIO } & 7\end{array}$

LIST OF PUBLICATIONS

LIST OF ABBREVIATIONS

$\begin{array}{ll}\text { INTRODUCTION } & 19\end{array}$

1. History 21

2. Acute myeloid leukaemia: definition and classification 23

2.1. The French-American-British classification system 24

2.2. The World Health Organization classification system 25

3. Epidemiology 28

4. Aetiology 30

4.1. Environmental factors $\quad 30$

4.2. Acquired diseases 31

4.3. Predisposing diseases 31

5. Pathogenesis 32

5.1. Chromosomal rearrangements in AML 32

5.2. Gene mutations in AML 35

5.3. The two-hit model of leukaemogenesis $\quad 37$

5.4. The MLL family of chromosomal rearrangements 39

5.4.1. Incidence and clinical relevance of $M L L$ rearrangements in leukaemia 41

5.4.2. MLL structure and function 42

5.4.3. Structure and function of MLL fusion proteins 44

5.4.4. MLL fusion partners in leukaemia 47

6. References 55

RATIONALE AND AIMS

MATERIAL AND METHODS, RESULTS AND DISCUSSION 79

1. Septins as $M L L$ fusion partners in myeloid neoplasia 81

Paper \#1: SEPT2 is a new fusion partner of MLL in acute myeloid leukaemia with $\mathrm{t}(2 ; 11)(\mathrm{q} 37 ; \mathrm{q} 23)$

Paper \#2: A novel MLL-SEPT2 fusion variant in therapy-related $\begin{array}{ll}\text { myelodysplastic syndrome } & 91\end{array}$

Paper \#3: Molecular characterisation of the MLL-SEPT6 fusion gene in acute myeloid leukaemia: identification of novel fusion transcripts and cloning of genomic breakpoint junctions 
Paper \#4: Coexistence of alternative MLL-SEPT9 fusion transcripts in an acute myeloid leukemia with $t(11 ; 17)(q 23 ; q 25)$

2. Septin gene expression changes in myeloid neoplasia 117

Paper \#5: Both SEPT2 and MLL are down-regulated in MLL-SEPT2 therapy-related myeloid neoplasia

Paper \#6: Expression pattern of the septin gene family in acute myeloid leukemias with and without MLL-SEPT fusion genes

GLOBAL DISCUSSION, CONCLUSIONS

AND FUTURE PERSPECTIVES

Paper \#7: Structural and expression changes of septin genes

in myeloid neoplasia

SUMMARY - RESUMO - RÉSUMÉ

Summary

179

Resumo

181

Résumé 
PREFACE

PREFÁCIO 
PREFACE

Nuno Cerveira, Doctoral Thesis 


\section{PREFÁCIO}

Na minha opinião uma tese corresponde sempre a um instantâneo de um período na nossa história pessoal, não só um ponto de chegada mas também, e fundamentalmente, um ponto de partida para novas viagens. A investigação, entendida como uma procura de significado para nós e para o mundo, tem sempre vários objectivos (ou desejos), que podem ou não ser concretizados. Sabemos aproximadamente de onde partimos mas não sabemos de todo qual o trajecto a percorrer e menos ainda onde, e quando, vamos chegar. Esta ignorância está claramente reflectida na estrutura que optei por dar a esta tese, entendida como uma narrativa de um percurso. A introdução, apesar de estruturada de forma clássica, pretende levar-nos simplesmente ao início do trajecto sugerindo mais do que realmente revelando. Seguem-se os objectivos e um pequeno resumo dos materiais e das metodologias utilizadas. Em seguida, na secção de resultados e discussão, são apresentados os 6 artigos originais publicados em revistas científicas da especialidade. Finalmente, na última secção, denominada discussão final, conclusões e perspectivas futuras, inclui um artigo de revisão que pretende integrar todos os resultados obtidos numa perspectiva abrangente, e lançar novas pistas para caminhos futuros.

A presente dissertação está escrita em inglês na sua quase totalidade, exceptuando este pequeno prefácio, os agradecimentos e a tradução do sumário. Este facto é a consequência lógica de todos os resultados terem sido publicados em revistas científicas internacionais, o que traduz a realidade indesmentível de a "língua da ciência" ser claramente o inglês. Na verdade, a "verdade" dos resultados científicos, por mais transitória que esta possa ser, é (deve ser) sempre o resultado da validação externa por peritos na área. No entanto, e em aparente contradição, a totalidade dos trabalhos conducentes à elaboração desta tese foram exclusivamente desenvolvidos no Serviço de Genética, do Instituto Português de Oncologia do Porto, apesar de muitas das amostras terem a sua origem em vários pontos do globo. Penso que as vantagens e limitações deste facto irão ficar bem patentes ao longo da narrativa.

Uma tese de doutoramento nunca é um trabalho individual. Assim, no final desta etapa, gostaria de agradecer sinceramente a todos aqueles que, de uma forma ou outra, contribuíram para que este fragmento da minha história pudesse ser escrito. 
Ao Prof. Manuel Teixeira, orientador "não oficial" deste trabalho, agradeço todo o entusiasmo, incentivo e apoio que me deu (e ainda alguns "travões" nas alturas certas), fazendo-me acreditar que, apesar das dificuldades, era possível chegar a bom porto.

Um agradecimento especial à Joana Santos, primeiro minha aluna de Mestrado e agora minha parceira de investigação e colega no grupo de Hemato-Oncologia Molecular. Grande parte do trabalho de investigação incluído nesta tese é também teu. $E$ isto diz quase tudo...

À Susana Bizarro, minha colega do grupo de Hemato-Oncologia Molecular, obrigado por todo o apoio, fundamental para que esta tese pudesse ver a luz do dia.

Ao grupo de Citogenética, particularmente à Cecília Correia, Lurdes Torres e Susana Lisboa, que colaboraram de forma mais próxima neste trabalho, o meu agradecimento especial por todos aqueles casos "interessantes" e/ou "estranhos" com que me foram aliciando. Ao fim de todos estes anos tenho, não com muito custo, de admitir que a Citogenética foi (é) quase sempre o meu ponto de partida.

Aos co-autores das publicações incluídas nesta dissertação agradeço a sua colaboração e disponibilidade.

A todos os restantes colegas do Serviço de Genética do IPO, o meu obrigado.

À "Associação Portuguesa Contra a Leucemia" e à "Comissão de Fomento da Investigação em Cuidados de Saúde", o meu agradecimento pelo financiamento dos trabalhos conducentes a esta tese.

Finalmente, mas sempre em primeiro lugar, gostaria de agradecer à minha família, e muito em especial aos meus pais por tudo o que sempre me proporcionaram. Pai, o teu apoio incondicional ficará comigo para sempre. Esta tese também é tua...

Obrigado Diogo pelo fantástico desenho da capa!

Porto, 12 de Fevereiro de 2010

Nuno Manuel Botelho Gonçalves Sampaio Cerveira 
LIST OF PUBLICATIONS

\section{LIST OF PUBLICATIONS}


LIST OF PUBLICATIONS 


\section{LIST OF PUBLICATIONS}

The following manuscripts were prepared and published as part of this Doctoral Thesis:

Paper \#1: Cerveira N, Correia C, Bizarro S, Pinto C, Lisboa S, Mariz JM, Marques M, Teixeira MR. SEPT2 is a new fusion partner of MLL in acute myeloid leukaemia with t(2;11)(q37;q23). Oncogene 2006, 25:6147-6152.

Paper \#2: Cerveira N, Santos J, Pinheiro M, Snijder S, van der Lelie H, Mellink C, Teixeira MR. A novel MLL-SEPT2 fusion variant in therapy-related myelodysplastic syndrome. Cancer Genet Cytogenet 2008, 185:62-64.

Paper \#3: Cerveira N, Micci F, Santos J, Pinheiro M, Correia C, Lisboa S, Bizarro S, Norton L, Glomstein A, Åsberg AE, Heim S, Teixeira MR. Molecular characterisation of the MLL-SEPT6 fusion gene in acute myeloid leukaemia: identification of novel fusion transcripts and cloning of genomic breakpoint junctions. Haematologica 2008, 93:1076-1080.

Paper \#4: Santos J, Cerveira N, Correia C, Lisboa S, Pinheiro M, Torres L, Bizarro S, Vieira J, Viterbo L, Mariz JM, Teixeira MR. Coexistence of alternative MLLSEPT9 fusion transcripts in an acute myeloid leukemia with t(11;17)(q23;q25). Cancer Genet Cytogenet 2010, 197:60-64.

Paper \#5: Cerveira C, Santos J, Bizarro S, Ribeiro FR, Lisboa S, Correia C, Torres L, Vieira J, Snijder S, Mariz JM, Norton L, van der Lelie H, Mellink CHM, Buijs A, Teixeira MR. Both SEPT2 and MLL are down-regulated in MLL-SEPT2 therapy-related myeloid neoplasia. BMC Cancer 2009, 9:147.

Paper \#6: Santos J, Cerveira N, Bizarro S, Ribeiro FR, Correia C, Torres L, Lisboa S, Vieira J, Mariz JM, Norton L, Snijder S, Mellink CH, Buijs A, Shih L-Y, Strehl S, Micci F, Heim S, Teixeira MR. Expression pattern of the septin gene family in acute myeloid leukemias with and without MLL-SEPT fusion genes. Leukemia Res 2010, 34:615-621. 
Paper \#7: Cerveira N, Santos J, Teixeira MR. Structural and expression changes of septin in myeloid neoplasia. Crit Rev Oncog 2009, 15:91-115.

All publications are reprinted in this Thesis in accordance with the respective "Copyright Transfer Agreements" 


\section{LIST OF ABBREVIATIONS}


LIST OF ABBREVIATIONS 


\section{LIST OF ABBREVIATIONS}

The following abbreviations, listed here in alphabetical order, were used throughout the text:

\begin{tabular}{ll} 
ALL & acute lymphoblastic leukaemia \\
AML & acute myeloid leukaemia \\
APL & acute promyelocytic leukaemia \\
BAC & bacterial artificial chromosome \\
BCR & breakpoint cluster region \\
CBF & core-binding factor \\
CML & chronic myeloid leukaemia \\
CN & cytogenetically normal \\
DMT & DNA methyltransferase homology domain \\
FAB & French-American-British \\
HDAC & histone deacetylase \\
HN-PCR & hemi-nested polymerase chain reaction \\
HOX & class I homeobox genes \\
LR-PCR & long-range polymerase chain reaction \\
PCR & polymerase chain reaction \\
PHD & plant homology domain \\
PTD & partial tandem duplication \\
qMSP & quantitative methylation-specific polymerase chain reaction \\
QR-PCR & quantitative real-time polymerase chain reaction \\
RT-PCR & reverse-transcription polymerase chain reaction \\
SNL & speckled nuclear localization site \\
SET & su(var), enchancer-of-zeste, trithorax \\
WHO & World Health Organization \\
\hline
\end{tabular}


LIST OF ABBREVIATIONS 
INTRODUCTION

\section{INTRODUCTION}


INTRODUCTION 


\section{INTRODUCTION}

\section{History}

Though vague descriptions of leukaemia appeared in the medical literature in 1825, for example when Armand Velpeau (1795-1867), a French anatomist and surgeon, described a 63-year-old Parisian lemonade salesman who was noted at post-mortem examination to have an enormous spleen and blood resembling 'thick pus', the first remarkably accurate clinical and pathological descriptions appeared in the 1840s, initially in the contemporary French literature and thereafter in the English and German literature (Henderson, 1996; Piller, 2001). In 1845, John Hughes Bennett (1812-1875) (Figure 1), an English physician, physiologist and pathologist at the Royal Infirmary in Edinburgh, Scotland, described the case of a 28-year-old roof tiler who presented with massive enlargement of his liver, spleen and lymph nodes (Bennet, 1845; Thomas, 2006).
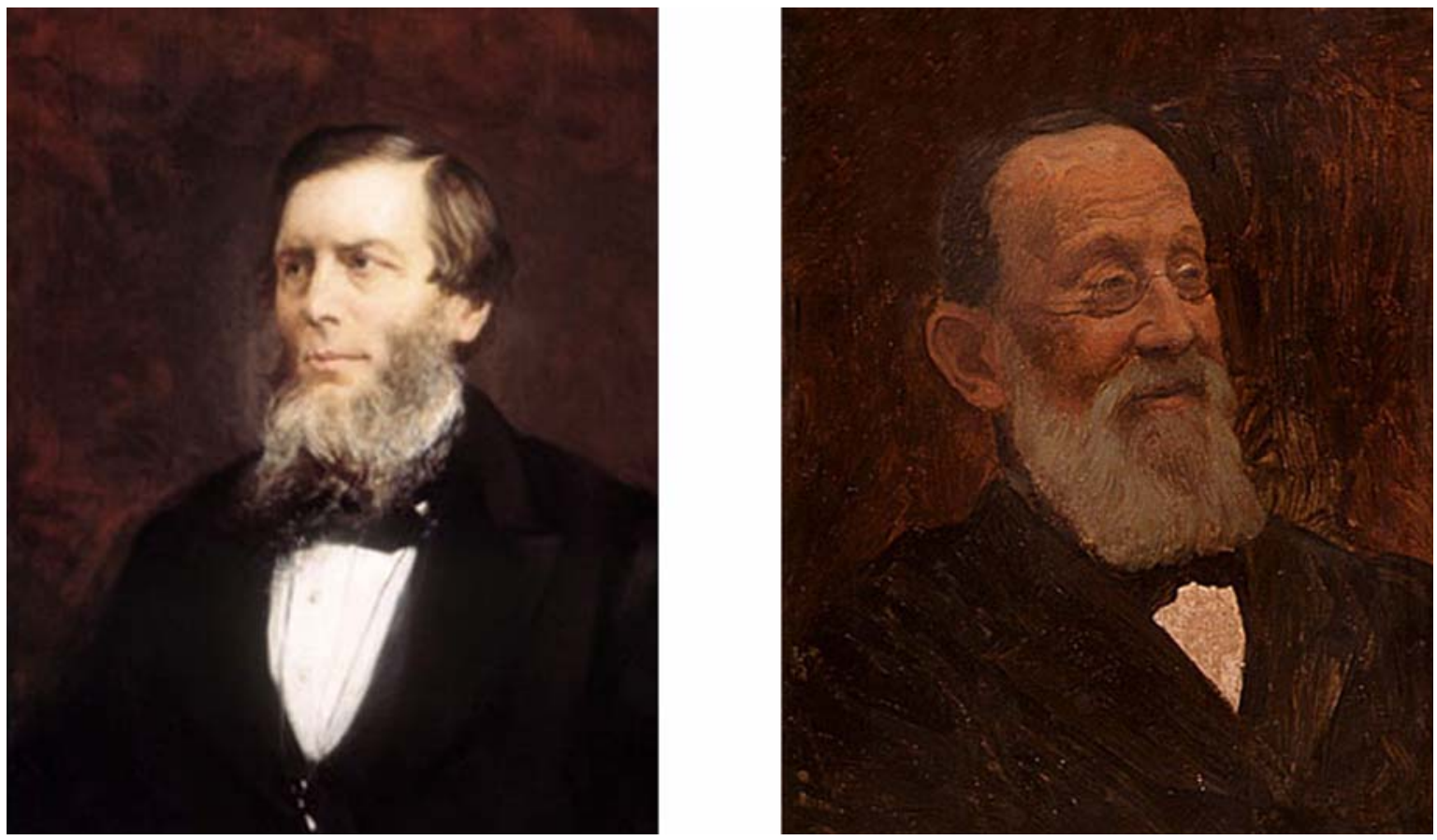

Figure 1. The discovery of leukaemia. John Hughes Bennett (1812-1875) (left) gave leukaemia its first published recognition as a clinical entity in October 1845. This first description was followed two weeks later by the report of a second case of leukaemia by Rudolph Virchow (1821-1902) (right).

Two weeks following this description, the German pathologist, anthropologist, public health activist, pre-historian, biologist and politician Rudolph Virchow (1821-1902) (Figure 1) described in Berlin the case of a 50-year-old lady, a cook, with a huge spleen 
(Virchow, 1845). Virchow wanted to name the newly described entity as "Leukhemia", a term he coined in 1847, which translated literally means "white blood" (Greek leukos

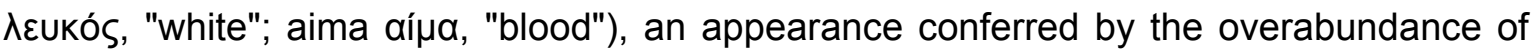
cells of the leukaemic clone, while Bennet argued that "leucocythaemia" was a more appropriate term (Tefferi, 2008). In the end, Virchow ceded priority to Bennett regarding the first description of the new disease (Piller, 2001).

Virchow recognized different types of leukaemia and distinguished between 'lymphatic' (lymphocytic) and 'splenic' (granulocytic) variants. The first well-documented case of acute leukaemia is attributed to Nikolaus Friedreich (1825-1882), a German pathologist and neurologist at Wurzburg (Friedreich, 1857), but Wilhelm Ebstein (18361912), a German physician, was the first to introduce the term "acute leukaemia" in 1889 to differentiate rapidly progressive and fatal leukaemias from the more indolent chronic leukaemias (Ebstein, 1889; Thomas, 2006). A vital discovery came in 1868 when Ernst Christian Neumann (1834-1918), professor of Pathological Anatomy at Königsberg, proposed the concept that blood cells are formed in the bone marrow, and that some cases of splenic leukaemia originated in the bone marrow, instead of the spleen, and used the term myelogene (myelogenous) leukaemia (Neumann, 1869; Neumann, 1870; Thomas, 2006). The next advance in the understanding of leukaemia pathophysiology came in 1877 as a result of the work of Paul Ehrlich (1854-1915), a German scientist who won the 1908 Nobel Prize in Physiology and Medicine. Ehrlich developed a triacid stain and introduced the names acidophil (later changed to eosinophil), basophil and neutrophil for the three different granulocyte types, and initiated the morphological era of haematology (Ehrlich, 1880). These discoveries lead to a simplified classification of leukaemia into myeloid and lymphoid subgroups. Ehrlich also developed the concept of the stem cell (Ehrlich, 1887). In 1900, the Swiss haematologist Otto Naegeli (1871-1938) described a new cell in the myeloid cell line, which he named the myeloblast, as an ancestor of granulocyte cells (Naegeli, 1900; Thomas, 2006). He also showed that the lymphoblast was the ancestor of lymphocytes. The presence of myeloblasts or lymphoblasts in the circulating blood formed a classic diagnosis of acute leukaemia (Ehrlich, 1887; Thomas, 2006). These scientific advances, complemented with the work of many other researchers, laid the foundation for our current understanding of the disease.

Today, the genetic basis of leukaemia is well documented, but when in 1914, Theodor Boveri (1862-1915), a German biologist, proposed that chromosomal abnormalities could have a critical role in cancer development, there were no means how to prove it. It was only much later, in the 1950s, when a series of technical developments allowed a more detailed examination of cancer cells chromosomes that his theories could be supported (Thomas, 2006). The precise number of human chromosomes was 
definitively established in 1956 (Tjio and Levan, 1956), and the first paper which showed that the chromosome pattern might be abnormal in acute leukaemias appeared in 1958 (Ford et al., 1958). In 1960, Peter Nowell discovered that exposure of human peripheral blood cells to phytohaemaglutinin stimulated the T lymphocytes to divide within 48 to 72 hours, and in this way transformed cytogenetic analysis into an accessible technique for the routine study of patients (Nowell, 1960). In the same year, working in collaboration with Hungerford, he identified a "minute" chromosome, the Philadelphia chromosome, in about $90 \%$ of patients with chronic myeloid leukaemia (CML) (Nowell and Hungerford, 1960). This was a major discovery because this small chromosome, called in honour of the city in which it was discovered, was the first consistent chromosome abnormality in any malignant disease. This finding was followed by the development of chromosomebanding techniques (Q-banding, G-banding, and R-banding) from 1969 to 1971, and initiated an era of leukaemia study based not solely on the appearance of the cells under the microscope (phenotype) but also by their chromosomal or genetic abnormalities (genotype) (Thomas, 2006). The use of Q-banding led in 1972 to the identification of the first consistent translocation involving chromosomes 8 and 21 - t(8;21)(q22;q22) - in acute myeloid leukaemia (AML) (Lindgren and Rowley, 1977). In 1973, Janet Rowley, from University of Chicago, was able to show that the Philadelphia chromosome was a reciprocal translocation between chromosomes 9 and 22 (Rowley, 1973) and, in the 1980 s, the $B C R-A B L$ chimeric gene and protein formed as a result of the $t(9 ; 22)(q 34 ; q 11)$ translocation was characterized and its central role in the pathogenesis of CML was established (De Klein et al., 1982). The finding that some chromosome translocations were also specifically associated with certain AML subtypes, such as the $t(15 ; 17)(q 22 ; q 21)$, characteristic of acute promyelocytic leukaemia (APL), in conjunction with the development and evolution of molecular based techniques, such as nucleotide sequencing (Sanger and Coulson, 1975) and the polymerase chain reaction (PCR) (Mullis et al., 1986), spurred the search for cancer gene involvement at or near chromosome breakpoints and led to the identification of new fusion genes. All these advances permitted a more precise understanding of the molecular pathology of specific leukaemia subtypes, the improvement of diagnostic and prognostic methods for the study of leukaemia, and the identification of molecular targets for therapy.

\section{Acute myeloid leukaemia: definition and classification}

AML is a heterogeneous group of clonal disorders of haematopoietic progenitor cells, which lose the ability to differentiate normally and to respond to normal regulators of proliferation. This loss leads to fatal infection, bleeding, or organ infiltration within 1 year of diagnosis, in the absence of treatment. 


\subsection{The French-American-British classification system}

The first reliable and systematic attempt of a uniform system for classification and nomenclature of $A M L$ was provided by the French-American-British (FAB) classification (Bennett et al., 1976; Bennett et al., 1985). This classification method was based on the morphology and histochemical properties of the leukaemic blasts, and divides leukaemia into acute versus chronic and lymphoid versus myeloid. In chronic leukaemia, a relatively mature phenotype is typical of leukaemic cells, whereas in acute leukaemia an overabundance of immature blood forming cells or blasts predominates (Bennett et al., 1985). Lymphoid and myeloid leukaemias are further subdivided by the predominant lineage and stage of differentiation of the leukaemic blasts. In this way, acute lymphoblastic leukaemia (ALL) is classified as L1, L2, and L3, and AML can be classified as M0 through M7, based primarily on morphology and cytochemistry with minimal immunophenotyping (Table 1) (Bennett et al., 1976; Bennett et al., 1985).

Table 1. Morphologic (modified FAB) description of acute myeloid leukaemia

\begin{tabular}{cl}
\hline M0 & AML with no Romanowsky or cytochemical evidence of differentiation \\
M1 & Myeloblastic leukaemia with little maturation \\
M2 & Myeloblastic leukaemia with maturation \\
M3 & Acute promyelocytic leukaemia \\
M3h & Acute promyelocytic leukaemia, hypergranular variant \\
M3v & Acute promyelocytic leukaemia, microgranular variant \\
M4 & Acute myelomonocytic leukaemia \\
M4eo & Acute myelomonocytic leukaemia with dysplastic marrow eosinophils \\
M5 & Acute monoblastic leukaemia \\
M5a & Acute monoblastic leukaemia, poorly differentiated \\
M5b & Acute monoblastic leukaemia, differentiated \\
M6 & "Erythroleukaemia" * \\
M6a & AML with erythroid dysplasia \\
M6b & Erythroleukaemia \\
M7 & Acute megakaryoblastic leukaemia \\
\hline
\end{tabular}

*Most M6 is M6a, not erythroleukaemia but acute myeloid leukaemia (AML) with erythroid dysplasia. M6b, true erythroleukaemia, is rare. Adapted from Bennett et al., 1976; Bennet et al., 1985. 


\subsection{The World Health Organization classification system}

Although remaining a useful shorthand description of myeloblast morphology, the FAB classification should not be used alone as classification of AML. Recurring, nonrandom cytogenetic abnormalities are common in haematological malignancies, and their recognition has paved the way for the identification and therapeutic exploitation of the clonal molecular lesions that are uniquely associated with specific subtypes of AML. Appreciation of the prognostic importance of these cytogenetic and molecular genetic abnormalities has provided the major thrust for the emergence of new genetically based leukaemia classifications. In this way, and to the extent that the molecular pathogenesis of AML has been clarified, patients are characterized by one of a series of recurring genetic abnormalities with prognostic implications (Grimwade et al., 1998; Slovak et al., 2000; Sahin et al. 2007; Paschka, 2008) (Table 2), which were incorporated in the most recent World Health Organization (WHO) classification of leukaemia (Harris et al., 1999; WHO, 2008; Tefferi et al., 2009; Vardiman et al., 2009) (Table 3).

Table 2. Examples of common genetic abnormalities in acute myeloid leukaemia by risk group

\begin{tabular}{|c|c|c|}
\hline Favourable & Intermediate & Adverse \\
\hline & Normal karyotype & $-5,5 q-$ \\
\hline & $+8,+6$ & $-7,7 q-$ \\
\hline $\mathrm{t}(8 ; 21)(\mathrm{q} 22 ; \mathrm{q} 22)$ & +21 & \\
\hline $\mathrm{t}(15 ; 17)(\mathrm{q} 22 ; \mathrm{q} 21)$ & +22 & Abnormal 3q \\
\hline $\begin{array}{c}\operatorname{inv}(16)(p 13 q 22) \\
t(16 ; 16)(p 13 ; q 22), 16 q-\end{array}$ & $-Y$ & Abnormal 9q \\
\hline \multirow[t]{7}{*}{ NPM1 mutation (FLT3-) } & $12 p-$ & 11q23 abnormalities \\
\hline & NPM1 mutation (FLT3+) & $\mathrm{t}(9 ; 22)(\mathrm{q} 34 ; \mathrm{q} 11)$ \\
\hline & CEBPA mutation & $20 q-$ \\
\hline & $\begin{array}{l}\text { Other noncomplex structural } \\
\text { or numerical abnormalities }\end{array}$ & $21 q-$ \\
\hline & & $17 p$ abnormality \\
\hline & & $\mathrm{t}(6 ; 9)(p 23 ; q 34)$ \\
\hline & & $\begin{array}{c}\text { Complex karyotype ( } \geq 3 \text { unrelated } \\
\text { abnormalities) }\end{array}$ \\
\hline \multicolumn{3}{|c|}{$\begin{array}{l}\text { It must be noted that risk group is dependent on treatment; e.g., acute promyelocytic leukaemi } \\
\text { (APL) risk group may change if ATRA (all-trans-retinoic acid) or aggressive anthracycline are no } \\
\text { used for treatment. Gene symbols presented according with the Human Gene Nomenclatur } \\
\text { Committee (HUGO). }\end{array}$} \\
\hline
\end{tabular}


This classification system is based on the systematic delineation of distinct clinical pathologic entities following a sequential process of first determining lineage and then stage of maturation of lymphoid and myeloid disorders, taking in account both cell surface and cytogenetic and/or molecular markers, and leading to the identification, in the case of AML, of several molecular categories as distinct disease entities (Harris et al., 1999; WHO, 2008; Tefferi et al., 2009; Vardiman et al., 2009) (Table 3).

Evolving systems of classification reflect an improved understanding of the molecular pathophysiology of leukaemia, which links pathways of hematopoietic development to the molecular (genetic) origin of specific leukaemias. In this way, gene expression profiling, although in its infancy, may prove in the future to be more specific and informative than current methods as methodologies for leukaemia classification (Bullinger et al., 2004; Valk et al., 2004a). 
Table 3. The World Health Organization (WHO) classification of acute myeloid leukaemia

Acute myeloid leukaemia with recurrent genetic abnormalities

AML with balanced translocations/inversions

Acute myeloid leukaemia with $\mathrm{t}(8 ; 21)(\mathrm{q} 22 ; \mathrm{q} 22) ;$ RUNX1-RUNXT1 (AML1-ETO)

Acute myeloid leukaemia with inv(16)(p13q22) or t(16;16)(p13;q22); CBFB-MYH11

Acute promyelocytic leukaemia with $\mathrm{t}(15 ; 17)(q 22 ; \mathrm{q} 21) ; P M L-R A R A$

Acute myeloid leukaemia with $\mathrm{t}(9 ; 11)(\mathrm{p} 22 ; \mathrm{q} 23) ;$ MLL-MLLT3 (MLL-AF9)

Acute myeloid leukaemia with $\mathrm{t}(6 ; 9)(\mathrm{p} 23 ; \mathrm{q} 34)$; DEK-NUP124

Acute myeloid leukaemia with inv(3)(q21q26.2) or $\mathrm{t}(3 ; 3)(\mathrm{q} 21 ; \mathrm{q} 26.2) ;$ RPN1-EVI1

Acute myeloid leukaemia (megakaryoblastic) with $\mathrm{t}(1 ; 22)(\mathrm{p} 13 ; \mathrm{q} 13) ; R B M 15-M K L 1$

AML with gene mutations

Mutations affecting FLT3, NPM1, CEBPA, KIT, MLL, WT1, NRAS, and KRAS

\section{Acute myeloid leukaemia with myelodisplasia-related changes}

Acute leukaemia with $20 \%$ or more peripheral blood or bone marrow blasts with morphological features of myelodysplasia or a prior history of a myelodysplastic syndrome (MDS) or myelodysplastic/myeloproliferative neoplasm (MDS/MPN), or MDSrelated cytogenetic abnormalities, and absence of the specific genetic abnormalities of AML with recurrent genetic abnormalities.

\section{Therapy-related myeloid neoplasms}

Therapy-related acute myeloid leukaemia (t-AML), myelodysplastic syndrome (t-MDS) and myelodysplastic/myeloproliferative neoplasms (t-MDS/MPN) occurring as late complications of cytotoxic chemotherapy and/or radiation therapy administered for a prior neoplastic or non-neoplastic disorder.

\section{Acute myeloid leukaemia, not otherwise specified}

Acute myeloid leukaemia with minimal differentiation

Acute myeloid leukaemia without maturation

Acute myeloid leukaemia with maturation

Acute myelomonocytic leukaemia

Acute monoblastic and monocytic leukaemia

Acute erythroid leukaemia

Acute megakaryoblastic leukaemia

Acute basophilic leukaemia

Acute panmyelosis with myelofibrosis

\section{Myeloid sarcoma}

Tumour mass consisting of myeloid blasts with or without maturation, occurring at an anatomical site other than the bone marrow.

\section{Myeloid proliferations related to Down syndrome}

Transient abnormal myelopoiesis

Myeloid leukaemia associated with Down syndrome

\section{Blastic plasmacytoid dendritic cell neoplasm}

Clinically aggressive tumour derived from the precursors of plasmacytoid dendritic cells, with a high frequency of cutaneous and bone marrow involvement and leukaemic dissemination.

Adapted from the WHO classification of tumours of haematopoietic and lymphoid tissues (2008). Gene symbols presented according with the Human Gene Nomenclature Committee (HUGO). 


\section{Epidemiology}

The reported frequency of leukaemia increased in the first half of the twentieth century, began slowing in its rate of acceleration in the 1940s, and has stabilized for the last 30 or so years (Espey et al., 2007). Leukaemia is one the ten most common malignancies in developed countries, accounting for $2.6 \%$ (44.800 cases) of all cancers diagnosed in Europe each year (3,1\% in the case of the USA) (Figure 2A), and for $3.1 \%$ (29.300 cases) of all cancer deaths (3.8\% in the USA) (Figure 2B) (Ferlay et al., 2007; Jemal et al., 2008).

For Portugal, the most recent data is from 2002, with reported age-standardized incidence rates of $8.8 / 10^{6}$ (587 new cases) and $6.1 / 10^{6}$ (473 new cases) and mortality of $5.0 / 10^{6}$ (370 deaths) and $3.4 / 10^{6}$ (313 deaths), in males and females, respectively (rates are per 100.000 population and age-adjusted to the world standard population) (Pinheiro et al., 2003; Ferlay et al., 2004). Although it is often thought of as primarily a childhood disease, leukaemia is diagnosed 10 times more often in adults than in children (Garcia et al., 2007; ACS, 2008). Nevertheless, leukaemia, and particularly ALL, is the most common cancer in children (aged 0 to 14 years) (ACS, 2008). Despite the significant improvements in leukaemia 5-year relative survival rate, particularly in children but also in adults, leukaemia is the leading cause of cancer death among females and males under 20 and 40 years of age, respectively (Ferlay et al. 2007; ACS, 2008).

Regarding AML, it is the predominant form of leukaemia during the neonatal period but represents a small proportion of cases during childhood and adolescence (Garcia et al., 2007; ACS, 2008). The incidence of AML remains generally constant through childhood and the early adult years and then begins to exponentially increase in frequency from about the age of 30 years (Garcia et al., 2007; ACS, 2008). AML accounts for 15 to 20 percent of acute leukaemia in children and 80 percent of acute leukaemia in adults, and it is slightly more common in males than in females (Espey et al., 2007; Garcia et al., 2007; ACS, 2008; Jemal et al., 2008). In adults, the median age at presentation is about 70 years, with three men affected for every two women (Estey et al., 2006). Approximately 13.000 new cases of $A M L$ occur annually, representing near $30 \%$ of all new cases of leukaemia in the USA, which result in almost 9.000 deaths (ACS, 2008). For Portugal, and regarding 2001, 243 new AML cases were registered, corresponding to nearly $34 \%$ of all new cases of leukaemia reported (RORENO, 2008). 
A

Europe (number of cases, both sexes, in thousands)

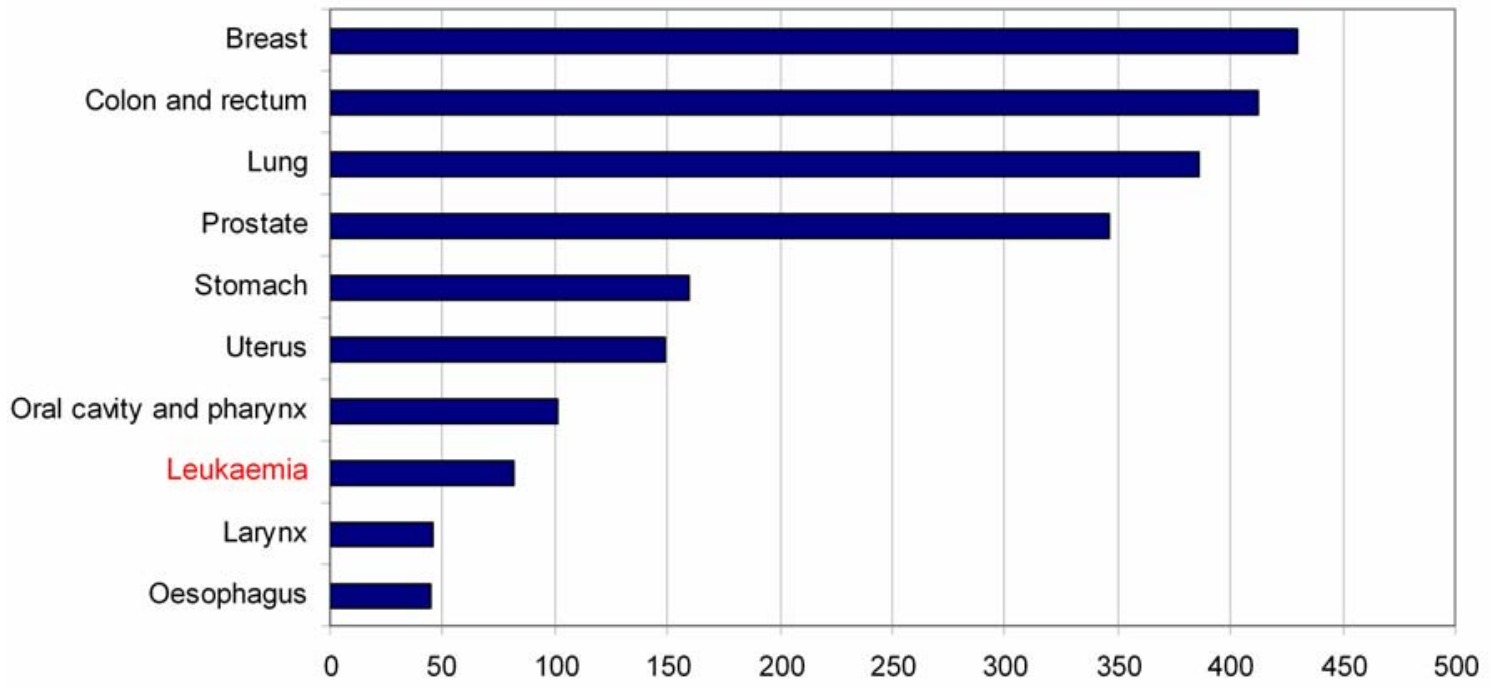

B

Europe (number of cases, both sexes, in thousands)

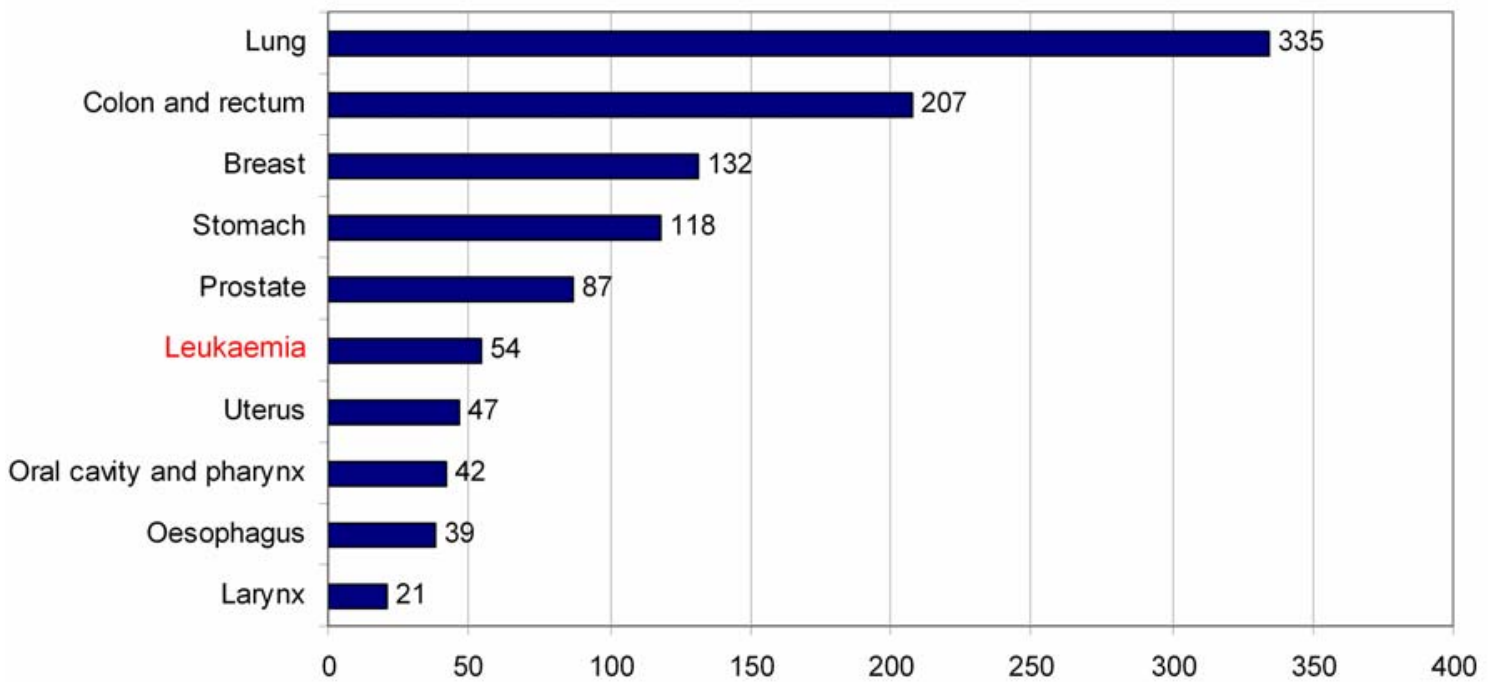

Figure 2. Estimated incidence (A) and mortality (B) due to cancer in Europe. Data compiled from Ferlay et al., 2007. 


\section{Aetiology}

\subsection{Environmental factors}

The number of people exposed to environmental causes of AML probably far exceeds the number of patients that develops the disease. Only three well-documented environmental factors are established as AML causal agents: high-dose external radiation exposure (Kato and Schull, 1982; Moloney, 1987), chemotherapeutic agents (Levine and Bloomfield, 1992; Thirman and Larson, 1996; van Leeuwen, 1996; Pui and Relling, 2000; Leone et al., 2007), and chronic benzene exposure (Snyder and Kalf, 1994; Savitz and Andrews, 1997; Snyder, 2002). The earliest evidence linking leukaemia to ionizing radiation comes from occupational exposures, including among radiologists and radium dial painters in the early years of the twentieth century (Moloney, 1987). The strongest evidence linking radiation to leukaemia can be found in survivors of the atomic bombings of Hiroshima and Nagasaki in 1945 (Kato and Schull, 1982). People who have survived atomic bombs are at high risk of AML, and abnormalities of chromosomes 5 and 7 are much more common in such patients than in patients born before 1945 without bomb exposure (Nakanish et al., 1999). Leukaemia is also common in workers in the nuclear industry, but not in people living near nuclear power plants (Cardis et al., 1995; von Muehlendahl, 1998). In addition, therapy-related acute myeloid leukaemia (t-AML) and myelodysplastic syndrome (t-MDS) are an increasingly recognized treatment complication in patients treated with radiotherapy and chemotherapy for previous haematological malignancies or solid tumours, and account for $10-20 \%$ of all cases of AML (Levine and Bloomfield, 1992; Thirman and Larson, 1996; van Leeuwen, 1996; Pui and Relling, 2000; Leone et al., 2007). There are two main types of therapy-related AML that depend on the type of chemotherapy agent employed (alkylating agent versus topoisomerase II inhibitor) (Levine and Bloomfield, 1992; Thirman and Larson, 1996; van Leeuwen, 1996; Pui and Relling, 2000; Leone et al., 2007). The commonest is seen 5-10 years after exposure to alkylating agents and is characterised by monosomies or deletions of the long arms of chromosomes 5 or 7 (Smith et al., 2003). The second type of therapy-related AML is seen 1-5 years after treatment with drugs such as doxorubicin and etoposide, which interact with DNA topoisomerase II and can be distinguished from other therapy-related leukaemia by its genetic signature: balanced translocations involving chromosome 11q23, that result in abnormalities in the MLL gene (Pui and Relling, 2000; Leone et al., 2007), and balanced translocations between chromosomes 15 and 17, $t(15 ; 17)$, which are characteristic of APL, and between chromosomes 8 and 21, t(8;21) (Cardis et al., 1995).

Benzene is the only non-therapeutic chemical agent for which there is persuasive evidence that it is a cause of leukaemia (Snyder and Kalf, 1994; Savitz and Andrews, 1997; Snyder, 2002). The association with leukaemogenesis is strongest for AML, but 
there is also a correlation between benzene exposure and development of ALL and MDS (Snyder and Kalf, 1994; Savitz and Andrews, 1997; Snyder, 2002). The evidence draws on numerous anecdotal reports, first observed in the Italian rotogravure and shoe industries in the 1920s and 1930s, as well as systematic occupational surveys, and the latency period between benzene exposure and development of leukaemia can range from 2 to 20 or more years (Snyder and Kalf, 1994; Savitz and Andrews, 1997; Snyder, 2002). AML associated with benzene exposure and cytotoxic chemotherapy are characterised by aberrations of chromosome 5 or 7 or both (Estey and Döhner, 2006). Cigarette smoking is the most common source of benzene exposure, and most, but not all, studies suggest an association between cigarette smoking and $\mathrm{AML}$, with the greatest risk occurring in current smokers (Brownson et al., 1993; Sandler et al., 1993; Kane et al., 1999). Cigarette-induced AML seems only variably associated with abnormalities in chromosomes 5 and 7 and is also accompanied by trisomy of chromosome 8 and, particularly, by a balanced translocation between chromosomes 8 and 21 or its morphological signature, FAB subtype M2 (Sandler et al., 1993; Davico et al., 1998; Moorman et al., 2002; Pogoda et al., 2002). The -5/-7 abnormalities associated with radiation, benzene exposure, and alkylating agents are identical to those observed in nontherapy-related AML (Fröhling et al., 2005; Estey et al., 2006). There is also evidence that maternal alcohol consumption during pregnancy increases the risk of infant leukaemia, especially AML, suggesting that in utero exposure to alcohol may contribute to leukaemogenesis involving myeloid cells (Shu et al., 1996).

\subsection{Acquired diseases}

AML may have its origin in the progression of other clonal disorders of the multipotent haematopoietic stem cell pool, such as chronic myeloid leukaemia, polycythemia vera, idiopathic myelofibrosis, primary trombocythemia, and clonal sideroblastic anaemia or oligoblastic myelogenous leukaemia (Fröhling et al., 2005; Rubnitz et al., 2008). Clonal progression seems to occur spontaneously, although with different probability in each disorder (Fröhling et al., 2005; Rubnitz et al., 2008). However, the frequency of clonal progression can be enhanced by radiation or chemotherapy in patients with polycythemia vera or essential trombocythemia (Najean et al., 1997; Sterkers et al., 1998).

\subsection{Predisposing diseases}

There are several conditions of non-myeloid origin that may predispose to $A M L$, such as anaplastic anaemia (polyclonal T-cell disorder) and myeloma (monoclonal B cell disorder) (Wiernik, 1997; Luca and Almanaseer, 2003). In addition, a number of inherited 
diseases seem to carry an increased risk of AML. Constitutional chromosomal abnormalities, such as trisomy 21 (Down syndrome) and trisomy 8 (Creutzig et al., 1996; Hasle, 2001; Zwaan et al., 2008; Beyer et al., 2005), DNA repair disorders such as Bloom syndrome and Fanconi's anaemia (Poppe et al., 2001; Tischkowitz and Dokal, 2004), tumour suppressor gene syndromes such as neurofibromatosis type I (Largaespada et al., 1996; Kratz et al., 2003), and congenital cytopenias such as Diamond-Blackfan syndrome, are some examples of inherited conditions that carry an additional risk of AML development (Vlachos et al., 2001).

\section{Pathogenesis}

Acute myeloid leukaemia is a heterogeneous group of leukaemias that arise in precursors of myeloid, erythroid, megakaryocytic, and monocytic cell lineages. These leukaemias result from the acquisition of chromosomal rearrangements and multiple gene mutations in either a hematopoietic multipotent cell or, more occasionally, a more differentiated, lineage-restricted progenitor cell, that is transformed in a so-called leukaemic stem cell, which keeps the ability to self-renewal.

\subsection{Chromosomal rearrangements in $A M L$}

Acute myeloid leukaemia is one of the most comprehensively studied neoplastic diseases. In this neoplasia, somatic mutations usually results from recurrent balanced rearrangements, most often a chromosomal translocation, that originates a rearrangement of a critical region of a proto-oncogene, but also from deletions of single chromosomes, such as 5q- or 7q-; gain or loss of whole chromosomes (+8 or -7); or chromosome inversions, such as inv(3), inv(16), or inv(8) (Table 4) (Mitelman et al., 2007). In addition, it appears that certain genomic loci are associated with specific subtypes of leukaemia. For example, more than 60 different recurring translocations target the $M L L$ gene locus on chromosome 11q23 and are generally associated with a myelomonocytic or monocytic AML phenotype (FAB M4 or M5) (Meyer et al., 2006; Meyer et al., 2009). As another example, five different translocations target the retinoic acid receptor locus (RARA), including the $t(15 ; 17)(q 22 ; q 21)$, which is the commonest, with all being associated with APL phenotype (FAB M3) (Lo-Coco et al., 2008). 
Table 4. Common chromosome abnormalities in acute myeloid leukaemia

\begin{tabular}{|c|c|c|c|}
\hline & Genes & $\begin{array}{l}\text { Morphological } \\
\text { association }\end{array}$ & Incidence \\
\hline \multicolumn{4}{|l|}{ Translocations/inversions } \\
\hline $\mathrm{t}(8 ; 21)(\mathrm{q} 22 ; \mathrm{q} 22)$ & $\begin{array}{c}R U N X 1-R U N X 1 T 1 \\
(A M L 1-E T O)\end{array}$ & M2 with Auer rods & $6 \%$ \\
\hline $\operatorname{inv}(16)(p 13 q 22)$ or $t(16 ; 16)(p 13 ; q 22)$ & CBFB-MYH11 & M4Eo & $7 \%$ \\
\hline $\mathrm{t}(15 ; 17)(\mathrm{q} 22 ; \mathrm{q} 21)$ & $P M L-R A R A$ & M3/M3v & $7 \%$ \\
\hline $\mathrm{t}(9 ; 11)(\mathrm{p} 22 ; \mathrm{q} 23)$ & $\begin{array}{c}M L L-M L L T 3 \\
(M L L-A F 9)\end{array}$ & M5 & $2 \%$ \\
\hline $\mathrm{t}(6 ; 11)(\mathrm{q} 27 ; \mathrm{q} 23)$ & $\begin{array}{c}M L L-M L L T 4 \\
(M L L-A F 6)\end{array}$ & M4 and M5 & $\sim 1 \%$ \\
\hline $\operatorname{inv}(3)(q 21 q 26)$ or $t(3 ; 3)(q 21 ; q 26)$ & EVI1-PSMD2 & M1, M4, M6, M7? & $\sim 1 \%$ \\
\hline $\mathrm{t}(6 ; 9)(p 23 ; q 34)$ & DEK-NUP214 & M2, M4 & $\sim 1 \%$ \\
\hline
\end{tabular}

Chromosomal imbalances

\begin{tabular}{cccc}
\hline+8 & - & M2, M4 and M5 & $9 \%$ \\
$-7 / 7 q-$ & - & No FAB preference & $7 \%$ \\
$-5 / 5 q-$ & - & No FAB preference & $7 \%$ \\
$-17 / 17 p-$ & TP53 & No FAB preference & $5 \%$ \\
$-20 / 20 q-$ & - & No FAB preference & $3 \%$ \\
$9 q-$ & - & No FAB preference & $3 \%$ \\
+22 & - & M4, M4Eo & $3 \%$ \\
+21 & - & No FAB preference & $2 \%$ \\
+13 & - & M0, M1 & $2 \%$ \\
+11 & $M L L^{*}$ & M1, M2 & $2 \%$ \\
Complex karyotype & - & & $10 \%$ \\
Normal karyotype & - & & $44 \%$ \\
\hline
\end{tabular}

*Partial tandem duplication of the MLL gene. ${ }^{* *}$ Three or more chromosomal aberrations in the absence of $t(8 ; 21)$, inv(16)/t(16;16), $t(15 ; 17)$, or $t(9 ; 11)$. Adapted from Byrd et al. (2002). Gene symbols presented according with the Human Gene Nomenclature Committee (HUGO). 
Of the more than 267 balanced chromosome aberrations identified in leukaemia, the majority result in the formation of fusion genes (Mitelman et al., 2007). Fusion of portions of two genes usually does not prevent the process of transcription and translation, thus the fusion gene encodes a fusion protein that, because of its abnormal structure, can disrupt normal cell pathways and predispose to malignant transformation. The mutant protein product is often a transcription factor or a key element in the transcription machinery that disrupts the regulatory sequences controlling growth rate, survival, differentiation and maturation of blood cell progenitors (Downing, 2003; Renneville et al., 2008). For instance, translocations that target the core-binding factor (CBF), a heterodimeric transcriptional complex essential for haematopoiesis, result in expression of dominant negative inhibitors of normal CBF function, such as the RUNX1RUNX1T1 (AML1-ETO) fusion protein, leading to impaired hematopoietic differentiation (Mrózek et al., 2008).

Most of these abnormalities have prognostic implications, allowing the stratification of patients by risk group (Table 5) and, as already discussed, are the basis of the WHO classification of leukaemia. 
Table 5. Risk group assignments of younger adults with acute myeloid leukaemia

\section{Favourable-Risk Group}

Balanced structural rearrangements:

$\mathrm{t}(15 ; 17)(\mathrm{q} 22 ; \mathrm{q} 21)$

$\mathrm{t}(8 ; 21)(\mathrm{q} 22 ; \mathrm{q} 22)$

$\operatorname{inv}(16)(p 13 q 22) / t(16 ; 16)(p 13 ; q 22)$

\section{Intermediate-Risk Group}

Normal karyotype

$46, X X / 46, X Y$

Balanced structural rearrangement:

$\mathrm{t}(9 ; 11)(\mathrm{p} 22 ; \mathrm{q} 23)$

Unbalanced structural rearrangements:

$$
\begin{gathered}
\operatorname{del}(7 q) \\
\operatorname{del}(9 q) \\
\operatorname{del}(11 q) \\
\operatorname{del}(20 q) \\
-Y \\
+8 \\
+11 \\
+13 \\
+21
\end{gathered}
$$

Numerical abnormalities: $\quad-Y$

\section{Unfavourable-Risk Group}

Complex karyotype

Balanced structural rearrangements:

Unbalanced structural rearrangement:

Numerical abnormalities: $\geq 3$ changes

$\operatorname{inv}(3)(q 21 q 26) / t(3 ; 3)(q 21 ; q 26)$

$\mathrm{t}(6 ; 9)(\mathrm{p} 23 ; \mathrm{q} 34)$

$\mathrm{t}(6 ; 11)(\mathrm{q} 27 ; \mathrm{q} 23)$

$\mathrm{t}(11 ; 19)(q 23 ; p 13.1)$

$\operatorname{del}(5 q)$

$-5$

$-7$

Adapted from Mrózek and Bloomfield, 2006.

\subsection{Gene mutations in AML}

Although gene rearrangements as a result of chromosomal translocations are key events in leukaemogenesis, they are usually not sufficient to cause AML. Additional genetic abnormalities, including mutations that affect genes that contribute to cell proliferation such as $F L T 3, K I T$, and RAS, mutations affecting other genes involved in myeloid differentiation, such as CEBPA, and mutations affecting genes implicated in cell cycle regulation or apoptosis such as TP53 and NPM1, also constitute major events in AML pathogenesis with relevant prognostic implications (Mrósek et al., 2007; Renneville et al., 2008) (Table 6). 
Table 6. Some examples of genes whose mutations or changes in expression have clinical prognostic significance in acute myeloid leukaemia

\begin{tabular}{|c|c|c|c|c|}
\hline Gene & Gene name & $\begin{array}{c}\text { Chromosomal } \\
\text { location }\end{array}$ & Change & Prognosis \\
\hline FLT3 & Fms-related tyrosine kinase 3 & $13 q 12$ & Mutation & Unfavourable \\
\hline NPM1 & $\begin{array}{c}\text { Nucleophosmin (nucleolar } \\
\text { phosphoprotein B23, numatrin) }\end{array}$ & $5 q 35$ & Mutation & Favourable \\
\hline$M L L$ & $\begin{array}{l}\text { Myeloid/lymphoid or mixed- } \\
\text { lineage leukaemia (trithorax) }\end{array}$ & $11 q 23$ & $\begin{array}{c}\text { Tandem } \\
\text { duplication }\end{array}$ & Unfavourable \\
\hline$B A A L C$ & $\begin{array}{c}\text { Brain and acute leukaemia, } \\
\text { cytoplasmatic }\end{array}$ & $8 q 22.3$ & Overexpression & Unfavourable \\
\hline CEBPA & $\begin{array}{l}\text { CCAAT/enhancer binding protein } \\
\qquad(\mathrm{C} / \mathrm{EBP}) \text {, alpha }\end{array}$ & $19 q 13.1$ & Mutation & Favourable \\
\hline$E R G$ & $\begin{array}{l}\text { v-ets erythroblastosis virus E26 } \\
\text { oncogene homolog (avian) }\end{array}$ & $21 q 22.3$ & Overexpression & Unfavourable \\
\hline
\end{tabular}

Gene symbols presented according with the Human Gene Nomenclature Committee (HUGO).

For instance, mutations of the FLT3 gene, including both point mutations within the kinase domain and internal tandem duplications (ITDs), are among the most common genetic changes seen in AML, occurring in 25 to 45 percent of cases and, in the case of FLT3-ITD mutations, are associated with a poor prognosis, particularly in those cases with loss of the remaining wild-type FLT3 allele (Mrósek et al., 2007; Renneville et al., 2008). Mutations of NPM1, which is also a fusion partner in gene fusions generated by recurrent chromosome translocations such as the $\mathrm{t}(2 ; 5)(\mathrm{p} 23 ; \mathrm{q} 35)$ in anaplastic large-cell lymphoma, the $t(3 ; 5)(q 25 ; q 35)$ in AML, and the $t(5 ; 17)(q 35 ; q 21)$ in APL (Morris et al., 1994; YonedaKato et al., 1996; Redner et al., 1996), have been found nearly exclusively in de novo AML, with an incidence of approximately $30 \%$ in adults (and $2-6 \%$ in children), thus becoming the most frequent genetic lesions in adult de novo AML (Renneville et al., 2008). NPM1 mutations occur predominantly in cytogenetically normal (CN) patients, and are associated with a significantly improved outcome in the absence of FLT3-ITD mutation (Mrósek et al., 2007; Renneville et al., 2008). An improved outcome is also associated with CEBPA mutations, which are also particularly common in AML cases with a normal karyotype, since they are associated with significantly better event-free survival, diseasefree survival and overall survival (Preudhomme et al., 2002; Barjesteh et al., 2003). In opposition, the partial tandem duplication of the MLL gene (MLL-PTD), the first gene mutation shown to affect prognosis in AML, particularly in CN patients, was shown to be associated with significantly shorter complete remission duration (Döhner et al., 2002), 
and the same seems to be true for the BAALC and ERG genes, whose overexpression is associated in both cases with an adverse prognosis, particularly in CN AML (Marcucci et al., 2005; Baldus et al., 2006).

\subsection{The two-hit model of leukaemogenesis}

As already said, as a result of a series of genomic lesions AML stem cells presents abnormalities in proliferation, cell death and haematopoietic differentiation. These oncogenic events can be divided in two classes according to the two-hit model of leukaemogenesis (Kelly and Gilliland, 2002; Speck and Gilliland, 2002) (Figure 3). In this model, there is a cooperation between gene rearrangements and mutations that confer a proliferative and/or survival advantage and those that impair hematopoietic differentiation (Kelly and Gilliland, 2002; Fröhling et al., 2005; Kosmider and Moreau-Gachelin, 2006; Moreau-Gachelin, 2006; Renneville et al., 2008). Although this model might be an oversimplification, class I mutations (exemplified by activating mutations of cell-surface receptors such as RAS, or tyrosine kinases such as $F L T 3$, result in enhanced proliferative and/or survival advantage for hematopoietic progenitors, leading to clonal expansion of the affected haematopoietic progenitors (Fröhling et al., 2005; Kosmider and MoreauGachelin, 2006; Moreau-Gachelin, 2006; Renneville et al., 2008).

The second type of lesion, class II mutations (exemplified by core-binding-factor gene rearrangements, resulting from the $\mathrm{t}(8 ; 21)$, inv(16), or $\mathrm{t}(16 ; 16)$, or by the $P M L-R A R A$ and $M L L$ gene rearrangements) are associated with impaired hematopoietic differentiation (Fröhling et al., 2005; Kosmider and Moreau-Gachelin, 2006; Moreau-Gachelin, 2006; Renneville et al., 2008).

The two-hit model of leukemogenesis, combining an activating lesion of tyrosine kinase pathways with an event blocking myeloid differentiation, is very interesting not only to model in vitro leukemogenesis, but also to screen molecular events in AML patients. It is attractive in explaining the origin of $t(8 ; 21)$ and $\operatorname{inv}(16) A M L$, each of which is often accompanied by KIT mutations (Dash and Gilliland, 2001; Care et al., 2003; Valk et al., 2004b; Cammenga et al., 2005; Cairoli et al., 2006; Schnittger et al., 2006), and t(15;17) AML characterised by FLT3 aberrations (Yokota et al., 1997; Yamamoto et al. 2001; Bowen et al., 2005). 


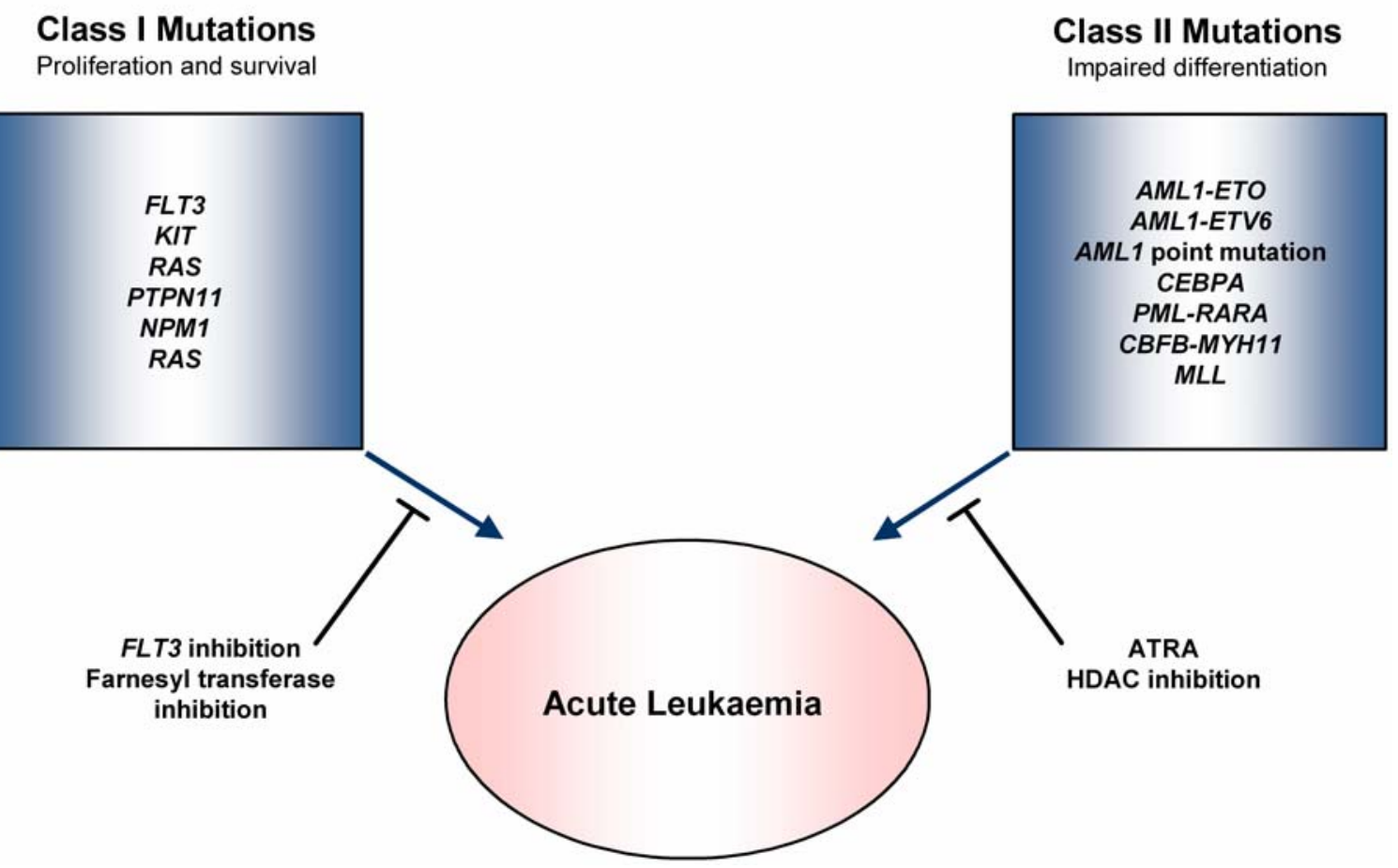

Figure 3. The two-hit model of leukaemogenesis. Model for cooperation between gene rearrangements and mutations that confer a proliferative and/or survival advantage to leukaemia cells, and those that impair haematopoietic differentiation. Class I mutations, exemplified by mutations in the tyrosine kinase $F L T 3$, result in enhanced proliferative and survival advantage for haematopoietic progenitors, and can be molecularly targeted with FLT3-specific inhibitors. Class II mutations, exemplified by the $P M L-R A R A$ gene rearrangement, are associated with impaired haematopoietic differentiation, and can be targeted by compounds that restore normal haematopoietic differentiation, such as ATRA (all-tans-retinoic acid).

Support for this model comes from the studies in mouse showing that class I and II mutations by themselves can only produce a myeloproliferative disorder but do not cause AML (Renneville et al., 2008). Only when both classes of mutations are present, i.e. cooperating, can AML develop. Additional support for the two-hit model comes from demonstration that class 1 and class 2 lesions occur together more commonly than do two class 1 or two class 2 lesions (Dash and Gilliland, 2001; Care et al., 2003; Downing, 2003; Valk et al., 2004b; Cammenga et al., 2005; Cairoli et al., 2006; Schnittger et al., 2006; Renneville et al., 2008). This model, however, cannot easily explain the $-5 /-7$ AML but could be modified to account for the role of epigenetic factors (Egger et al., 2004). Specifically, various putative tumour suppressor genes are hypermethylated and thus silenced in AML, and because hypermethylation, once present, is permanent, it is functionally equivalent to a genetic mutation (Toyota et al., 2001). Many of the identified gene mutations that affect proliferation or differentiation pathways represent potential 
targets for the development of new drugs (Figure 3). Class I mutations can be molecularly targeted with FLT3-specific inhibitors, or with farnesyltransferase inhibitors, which preclude localization of RAS to the plasma membrane. Class II mutations might be targeted by compounds that restore normal haematopoietic differentiation, as in the use of all-trans-retinoic acid (ATRA) for the treatment of acute promyelocytic leukaemia that is associated with the PML-RARA fusion, and potentially by histone deacetylase (HDAC) inhibitors (Renneville et al., 2008).

\subsection{The MLL family of chromosomal rearrangements}

Among cancer-related chromosomal aberrations that are shedding new light on the origins of $A M L$, the family of rearrangements involving the Myeloid/Lymphoid Leukaemia or Mixed Lineage Leukaemia gene (MLL, also known as HRX, ALL-1, and HTRX1) on chromosome 11, band q23 is proving to be a fertile area of investigation. The MLL gene is the mammalian homolog of Drosophila trithorax $(\operatorname{trx})$, the founding member of trithorax group proteins. As noted earlier, the MLL locus is involved in more than 60 different chromosomal translocations with a remarkably diverse group of fusion partners (Meyer et al., 2006; Meyer et al., 2009), and is associated mostly with the FAB subtype M4 or M5. $M L L$ rearrangements include chromosomal translocations, gene internal duplications, chromosome $11 \mathrm{q}$ deletions or inversions, and $M L L$ gene insertions into other chromosomes, or vice versa (Biondi et al., 2000; Meyer et al., 2006) (Figure 4). Leukaemias that bear translocations involving the $M L L$ gene possess unique clinical and biological characteristics. 


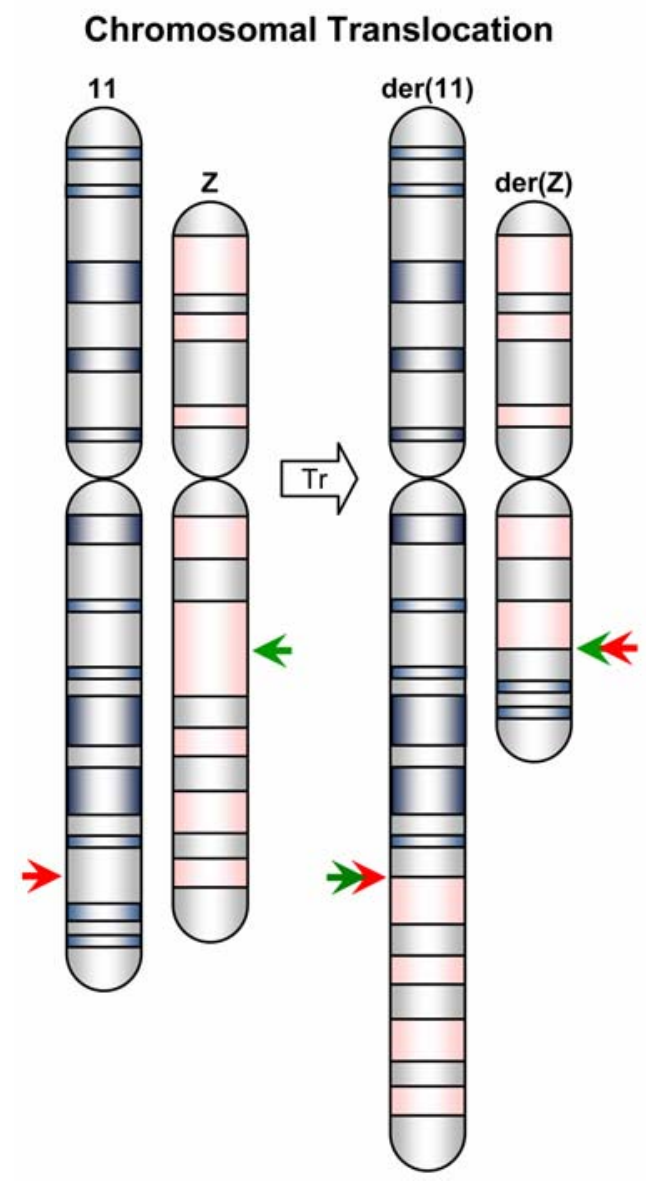

MLL Gene Duplication
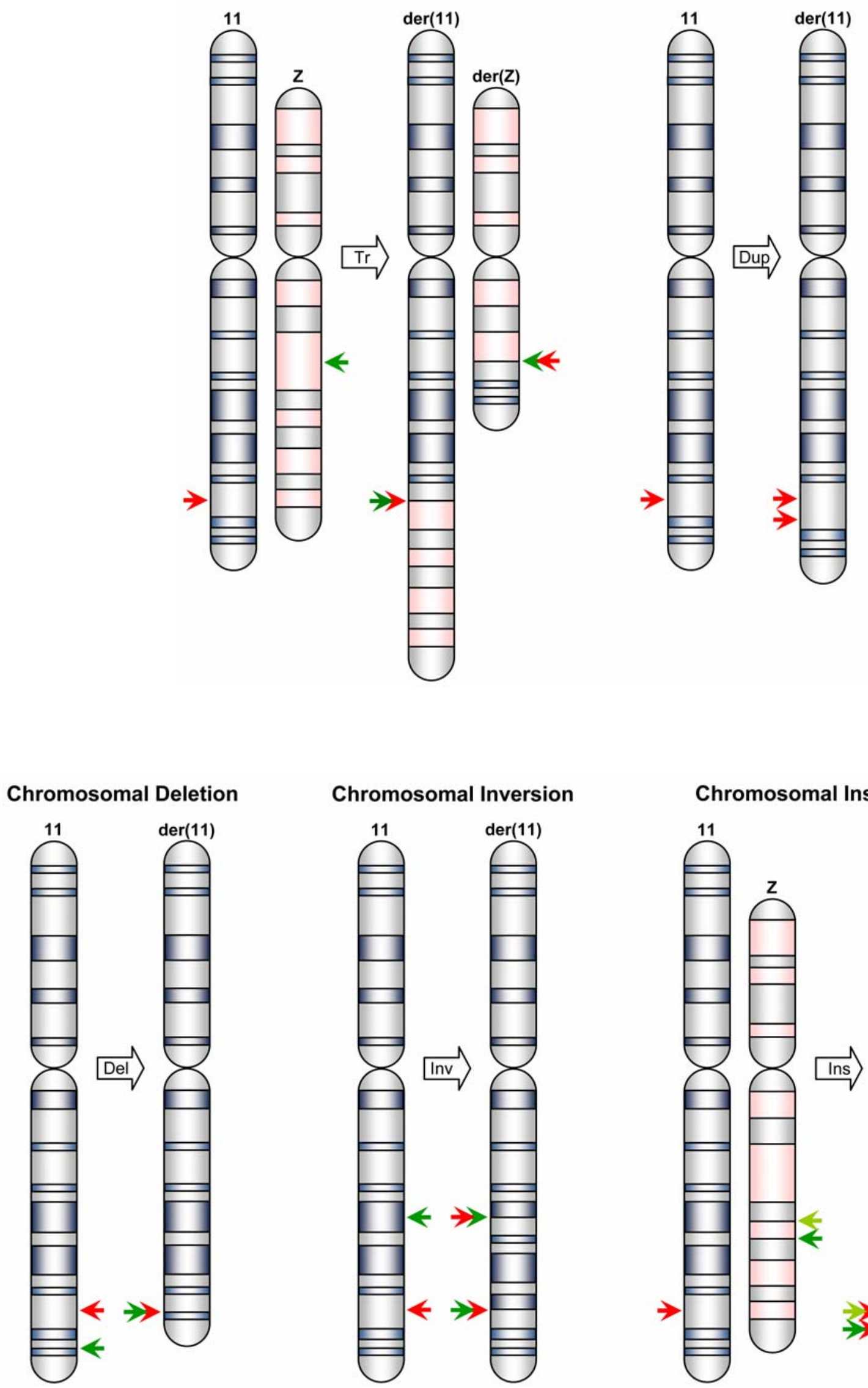

Chromosomal Inversion

Chromosomal Insertion
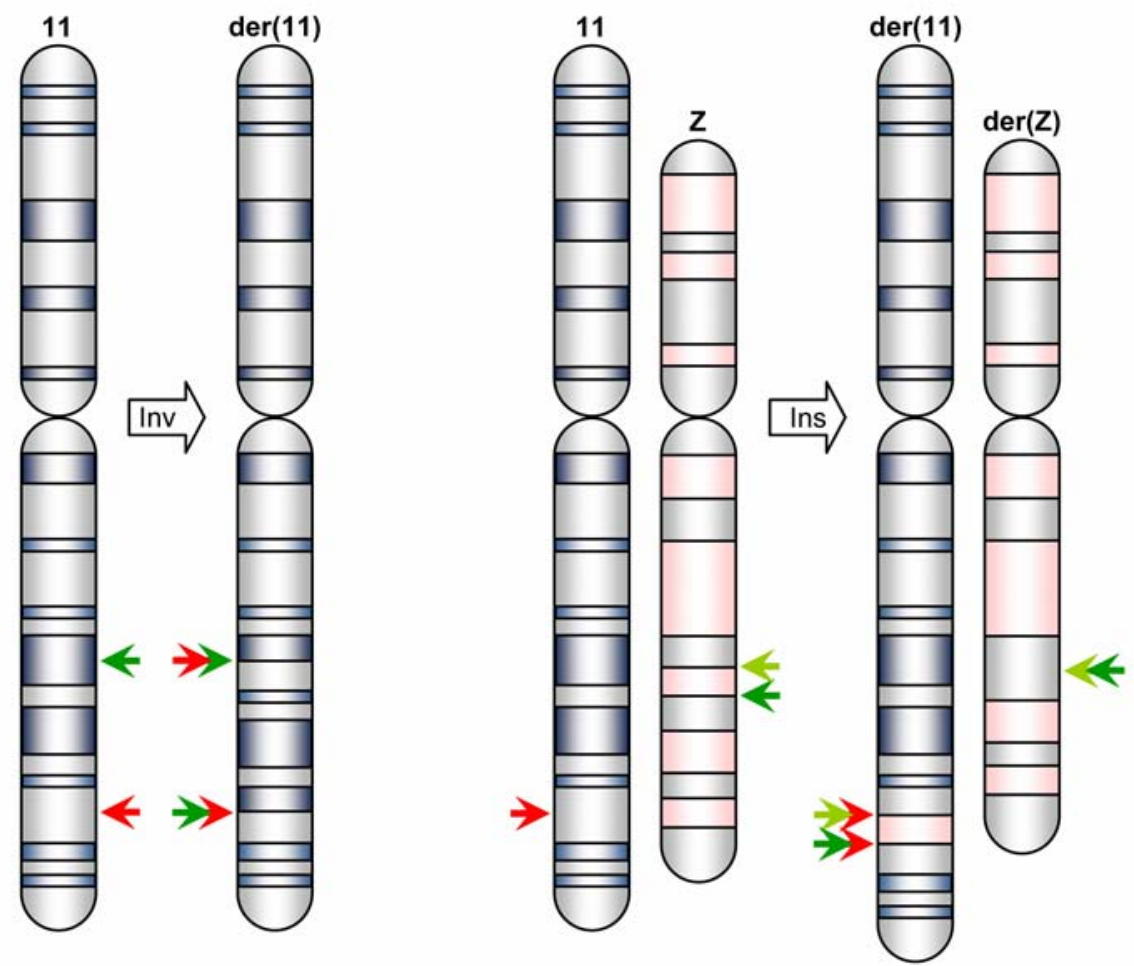
Figure 4. Several possibilities to generate $M L L$ rearrangements. $M L L$ rearrangements include chromosomal translocations, $M L L$ gene internal duplications ( $M L L$ introns 2-9, 2-11, 4-9, $4-11$ or 3-8), chromosome 11q deletions or inversions (deletions are caused by fusion of $M L L$ with a telomer-located gene and inversions are created by turning around a chromosome 11 fragment), and $M L L$ gene insertions into other chromosomes, or vice versa, the insertion of chromatin material into MLL. The MLL gene is shown as a red arrowhead, whereas potential translocation partner genes are shown as a green arrowhead.

\subsubsection{Incidence and clinical relevance of MLL rearrangements in leukaemia}

Overall, leukaemias that bear $M L L$ rearrangements are found in approximately $10 \%$ of human leukaemias (Huret et al., 2001). MLL rearrangements are found in $>70 \%$ of infant leukaemias, whether the immunophenotype is more consistent with ALL or AML, but are less frequent in leukaemias from older children (Biondi et al., 2000; Daser and Rabbitts, 2005). MLL translocations are also found in approximately $10 \%$ of adult AML, and can also be found in a proportion of patients with therapy-related leukaemia after treatment for other malignancies with topoisomerase II inhibitors, such as anthracyclines (e.g. doxorubicin and epirubicin) and epipodophyllotoxins (e.g. etoposide and tenoposide) (Biondi et al., 2000; Huret et al., 2001; Daser and Rabbitts, 2005; Krivtsov and Armstrong, 2007). The strong clinical and morphological heterogeneity within the leukaemia classes, is reflected at the molecular level in specific gene expression profiles (Armstrong et al., 2002; Yeoh et al., 2002; Ferrando and Look, 2003; Rozovskaia et al., 2003). Independent of their association with other high-risk features at presentation, 11q23 rearrangements are strongly predictive of poor clinical outcome (Biondi et al., 2000). Patients with MLLrearranged ALL have a particularly poor outcome compared with children with other forms of ALL, and $M L L$-rearranged leukaemias that occur after treatment with topoisomerase II inhibitors have a similarly poor prognosis (Chen et al., 1993; Krivtsov and Armstrong, 2007). Interestingly, MLL-MLLT3 (MLL-AF9) rearranged AML has an intermediate survival and one that is superior to AML with other 11q23 translocations (Felix et al., 1995; Mrózek et al., 1997; Rubnitz et al., 2002), showing that, at least in some cases, the fusion partner is relevant to the phenotype of $M L L$-rearranged AML. The association of $M L L$ translocations with a young age at diagnosis, the presence of $M L L$ translocations in both $A L L$ and AML, and the poor clinical outcome of patients with MLL fusions have generated much interest in the biology of $M L L$-translocation-associated leukaemias. 


\subsubsection{MLL structure and function}

The MLL gene is approximately $89 \mathrm{~kb}$ long, consists of 37 exons, and encodes a 3,969 amino acid nuclear multi-domain protein with a complex domain structure, that is ubiquitously expressed in haematopoietic cells including stem and progenitor populations (Figure 5) (Ayton and Cleary, 2001; Popovic and Zeleznik-Le, 2005).

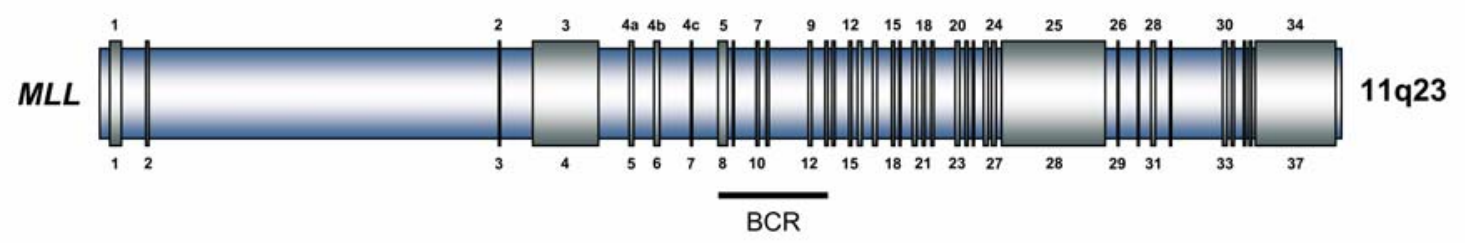

Figure 5. Schematic representation of the $M L L$ gene structure. $M L L$, the mammalian homolog of Drosophila trithorax (trx), maps to $11 \mathrm{q} 23$, is approximately $89 \mathrm{~kb}$ long and consists of 37 exons. The two MLL exon nomenclatures are depicted. Balanced translocations involving $M L L$ cluster between exons 8 and 13 (or exons 5 and 10, depending of the published exon nomenclature used), in the $8.3 \mathrm{~Kb}$ breakpoint cluster region (BCR).

The wild-type MLL protein structure has been intensively studied in the last years (Figure 6) (Meyer et al., 2006; Krivtsov and Armstrong, 2007; Meyer et al., 2009). The 500 $\mathrm{kDa}$ full length MLL precursor undergoes evolutionarily conserved site-specific proteolysis to generate a mature MLL heterodimer (Liu et al., 2008). The mature MLL protein (3968 amino acids) consists of two non-covalently associated subunits [MLLN (300 kDa) and MLLC (180 kDa)] produced by cleavage of nascent MLL by taspase 1 after amino acid residues 2,666 [cleavage site 1 (CS1)] and 2,718 (CS2) (Huret et al., 2001). The fragments translocate into the nucleus where they remain non-covalently associated, appearing as punctate sub-nuclear spots (Yano et al., 1997; Nakamura et al., 2002; Yokoyama et al., 2002; Hsieh et al., 2003a; Hsieh et al., 2003b). The N-terminus contains three short AT-hook motifs (ATH1-3), which are thought to mediate binding to the minor groove of AT-rich genomic DNA sequences (Huret et al., 2001). There are two speckled nuclear localization (SNL) sites (SNL1 and SNL2) immediately C-terminal to the AT-hooks that are followed by a transcriptional repression domain (TRD) consisting of two functional subunits, RD1 and RD2. RD1 contains a DNA methyltransferase (DMT) homology domain that includes a cysteine-rich $\mathrm{CxxC}$ zinc-finger motif that may recruit proteins such as HPC2 and the transcriptional co-repressor CtBP. RD2 recruits histone deacetylases HDAC1 and HDAC2 (Huret et al., 2001; Krivtsov and Armstrong, 2007). The plant 
homology domain (PHD) zinc-finger motifs may mediate binding of the cyclophilin, CYP33, and potentially other proteins (Fair et al., 2001).

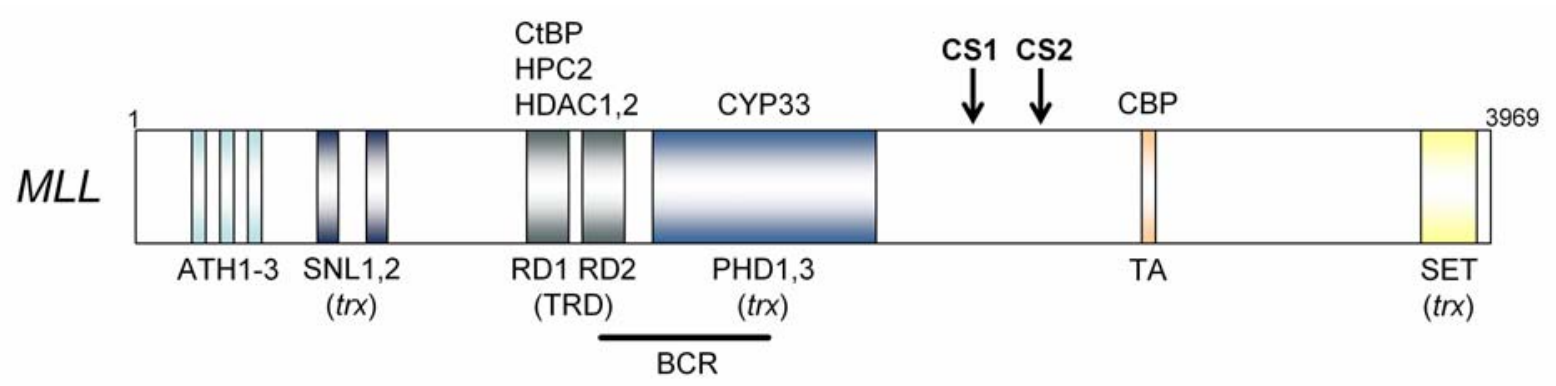

Figure 6. Schematic representation of the structure of the wild-type MLL protein. ATH1-3 (AT-hook motifs), SNL1-2 (speckled nuclear localization sites), TRD (transcriptional repression domain), PHD 1-3 (plant homology domain zinc-finger motifs), TA (transcriptional activation domain), SET [Su(var), enchancer-of-zeste, trithorax domain], BCR (breakpoint cluster region).

The transcriptional activation (TA) domain recruits the transcriptional co-activator CREBBP (CREB-binding protein) and precedes a C-terminal SET [Su(var), enchancer-ofzeste, trithorax] domain that possesses histone $\mathrm{H} 3$ lysine 4 (H3K4) methyltransferase activity and is, as SNL1-2 and PHD 1-3, structurally homologous to Drosophila melanogaster trithorax (trx) (Briggs et al., 2001; Ernst et al., 2001; Milne et al., 2002; ).

Under normal circumstances, $M L L$ encodes a histone methyltransferase that, like other methyltransferases, has been reported to assemble a supercomplex of proteins of varied function involved in transcriptional regulation (Nakamura et al., 2002; Yokoyama et al., 2004; Dou et al., 2005). Although not completely elucidated, current evidence suggests that MLL binds DNA in a non-sequence-specific manner through the AT-hook domains and the domain homologous to DMT, and is a major regulator of class I homeobox $(H O X)$ gene expression, directly interacting with HOX promoter regions (Ayton and Cleary, 2001; Popovic and Zeleznik-Le, 2005). HOX genes are transcription factors involved in the specification of cell fate during development, playing a key role in the regulation of hematopoietic development (Jude et al., 2007; McMahon et al., 2007), and it seems plausible that deregulation of MLL protein activity might result in abnormal patterns of HOX gene expression in hematopoietic stem cells or progenitors (Huret et al., 2001; Li et al., 2005; Slany et al., 2005; Krivtsov and Armstrong, 2007). Normally, during haematopoiesis HOX genes are expressed in lineage- and stage-specific combinations; however, cell commitment to myeloid or erythroid lineages is accompanied by global downregulation of HOX gene expression (Pineault et al., 2002; Grier et al., 2005). A 
failure to downregulate $\mathrm{HOX}$ expression can inhibit hematopoietic maturation and can lead to leukaemia (Grier et al., 2005). As HOX genes are the best characterized MLL targets, the significance of their deregulation in $M L L$ leukaemias has been extensively studied (Ayton and Cleary, 2003; Kumar et al., 2004; So et al., 2004; Caslini et al., 2007). However, HOX deregulation does not seem to be required in all cases of $M L L$ fusions. For instance, HOXA7 and HOXA9 upregulation is a prerequisite for MLL-MLLT1 (MLL-ENL) initiated leukaemia (Zeisig et al., 2004), but are dispensable for leukaemias induced by MLL-MLLT3 (MLL-AF9) and MLL-GAS7 (Kumar et al., 2004; So et al., 2004). Therefore, it is likely that deregulation of critical pathways other than HOX genes plays an instrumental role in $M L L$ leukaemias. Indeed, gene expression analyses suggest the existence of a number of other potentially important target genes in $M L L$-rearranged leukaemias (Popovic and Zeleznik-Le, 2005).

\subsubsection{Structure and function of MLL fusion proteins}

$M L L$ translocations, as many other translocations found in leukaemia, are probably the result a failure of appropriate DNA double strand break repair in developing haematopoietic cells (Richardson and Jasin, 2000). Balanced translocations involving the $M L L$ cluster between exons 8 and 13 (or exons 5 and 10, depending of the published exon nomenclature used), in the $8.3 \mathrm{~Kb}$ breakpoint cluster region (BCR) resulting in loss of the PHD and distal domains and fusion to one of many different translocation partners (Figures 5, 6 and 7, Table 8). Presumably, the breaks are limited to this region because not only the BCR contains topoisomerase II cleavage sites along with nuclear matrix attachment regions that are likely to contribute to the mechanism by which translocations occur (Strissel et al., 1998), but also because more proximal or distal breaks are not compatible with transformation (Hess, 2004). Indeed, the presence of the PHD fingers in the MLL fusion protein MLL-MLLT3 (MLL-AF9) can block immortalization of hematopoietic progenitors, leading to reduced association with the HOXA9 locus and suppressing HOXA9 upregulation in hematopoietic progenitors, providing an explanation for why $M L L$ translocation breakpoints exclude the PHD fingers and suggesting a possible role for these domains in the regulation of the function of the wild-type MLL protein (Muntean et al., 2008). In addition, all identified $M L L$ fusions contain the first 8-13 exons of $M L L$ and a variable number of exons from a fusion partner gene. Accordingly, the fusion genes encode chimeric proteins harbouring the $\mathrm{NH}_{2}$-terminal amino acids of $\mathrm{MLL}$ and the $\mathrm{COOH}$-terminal amino acids of the partner protein, with the rearrangements always occurring such that an in-frame chimeric protein is produced (Huret et al., 2001; Krivtsov and Armstrong, 2007). 


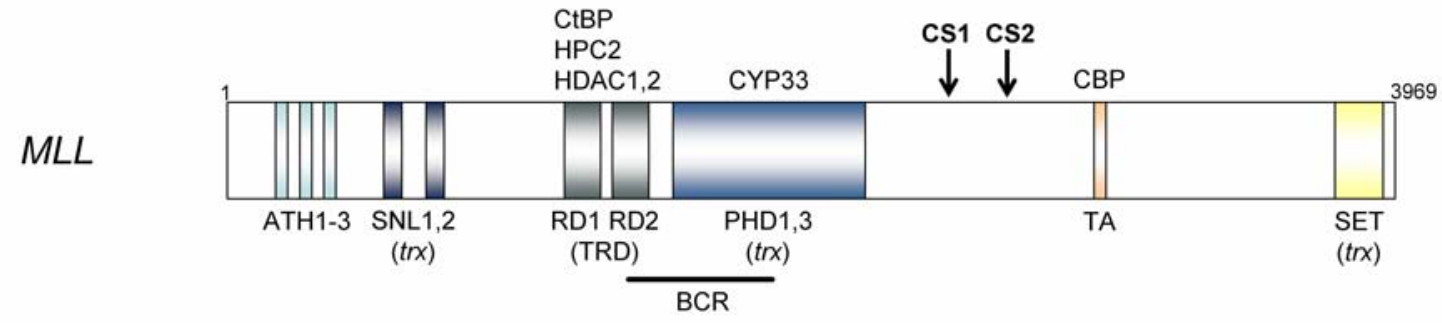

$M L L-F P G$

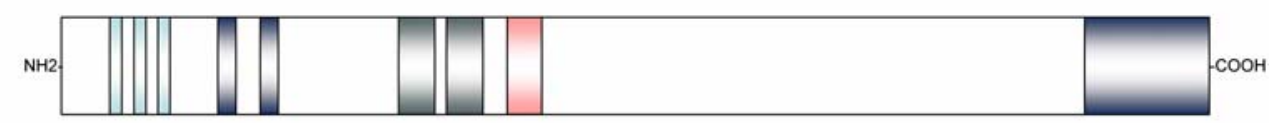

FPG

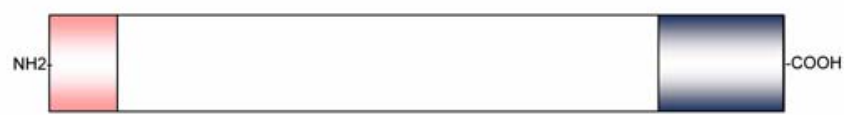

Figure 7. Schematic representation of the structure of MLL fusion proteins generated by $M L L$ translocations. A typical MLL fusion protein contains the $\mathrm{N}$-terminus of MLL encoded by the first 8 to 13 exons and the C-terminus of one of the known 64 fusion partner genes identified to date. BCR (breakpoint cluster region), FPG (fusion partner gene), ATH1-3 (AThook motifs), SNL1-2 (speckled nuclear localization sites), TRD (transcriptional repression domain), PHD 1-3 (plant homology domain zinc-finger motifs), TA (transcriptional activation domain), SET [Su(var), enchancer-of-zeste, trithorax domain].

$M L L$ can be fused with a wide variety of nuclear and cytoplasmatic proteins, and it undergoes oncogenic activation by multiple mechanisms, including acquisition of transcriptional effector domains (following fusion with nuclear transcription factors, cofactors, or chromatin remodelling proteins) and dimerization (Krivtsov and Armstrong, 2007). The major contribution of the fusion partners investigated so far seems to be to convert the rearranged MLL protein to a potent transcriptional activator, and it is usually accepted that deregulation of the MLL protein function is the key event in MLL-mediated leukaemogenesis (Krivtsov and Armstrong, 2007). Despite similarities between some of the more common $M L L$ translocations, many $M L L$ fusion partners are not transcription factors (Meyer et al., 2006, Krivtsov and Armstrong, 2007; Meyer et al., 2009). The finding of self-association motifs among these MLL fusion proteins suggests that, in these cases, the dimerization of MLL is the mechanism responsible for transformation (So et al., 2003; So and Cleary, 2003). Although the mechanisms by which the dimerization of truncated MLL makes it transforming have not been elucidated, it is known that dimerization of 
truncated MLL converts it into an extremely potent transcriptional transactivator that has increased binding affinity for HOX gene promoters (So et al., 2003a). In this way, it may be that all that is necessary for MLL fusions to be oncogenic is the ability of the fusion partner to direct oligomerization of the fusion protein. However, there is increasing evidence supporting the hypothesis that $M L L$ fusion partners are not randomly chosen, but rather functionally selected (So et al., 2003; So and Cleary, 2003). For instance, the most frequent MLL fusion partners AFF1 (AF4), MLLT3 (AF9), MLLT1 (ENL) and MLLT10 (AF10) have been shown to belong to the same nuclear protein network (Meyer et al., 2006; Meyer et al., 2009). Furthermore, the carboxyl-terminal domain of ELL and MLLT10 (AF10) was shown to be required for the leukaemic transformation associated with the MLL-ELL and MLL-MLLT10 (MLL-AF10) fusion proteins, respectively (DiMartino et al., 2000, 2002). This suggests that AFF1 (AF4), MLLT3 (AF9), MLLT10 (AF10), MLLT1 $(E N L), E L L$ and presumably other fusion partners possess activity beyond simple oligomerization.

Another type of $M L L$ rearrangement, $M L L-P T D$, is a result of internal tandem duplication of a varied number of exons 5 to 12 (or exons 3 to 9 , depending of the published exon nomenclature used) duplicated and inserted before exon 11 or 12 (Schichman et al.,1994; Caligiuri et al., 1996; Löchner et al., 1996) (Figure 8). MLL-PTD somewhat resemble dimerized $M L L$ translocations, because the same domains are affected by the intra-chromosomal duplication (Basecke et al., 2006).

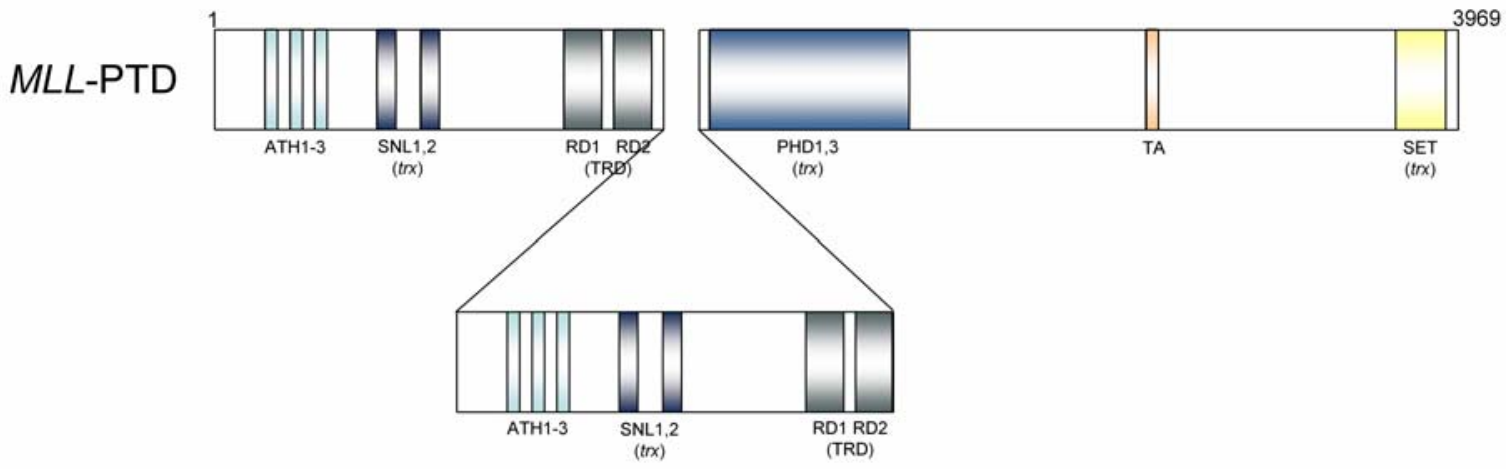

Figure 8. Schematic representation of the structure of the MLL partial tandem duplication (MLL-PTD). The MLL-PTD contains a variable number of exons 5 to 12 (or exons 3 to 9 , depending of the published exon nomenclature used) duplicated and inserted before exon 11 or 12. ATH1-3 (AT-hook motifs), SNL1-2 (speckled nuclear localization sites), TRD (transcriptional repression domain), PHD 1-3 (plant homology domain zinc-finger motifs), TA (transcriptional activation domain), SET [Su(var), enchancer-of-zeste, trithorax domain]. 
These findings imply that the duplication of a set of relevant domains by internal tandem duplication may induce the same effect as functional multiplication of these regions by dimerization, in which the translocation partner has no transactivation potential (Ayton and Cleary, 2001; So et al., 2003; Strehl et al., 2003; So and Cleary, 2004).

The duplicated N-terminal portion of MLL is devoid of the transactivation and SET domain, but contains the potential DNA-binding AT hooks and DNA methyltransferase homology region (Schnittger et al., 1998; 2000; Daser and Rabbitts, 2005). So an increased affinity and aberrant recruitment of coactivators or prevention of corepressor binding would lead to an inappropriate maintenance of target gene expression (e.g. the HOX gene family), a gain of function instead of a dominant negative effect (Hsu and Look, 2003; Martin et al., 2003; So et al., 2003; So and Cleary, 2004).

\subsubsection{MLL fusion partners in leukaemia}

One of the most notable features of $M L L$ is the extraordinary diversity of its fusion partners. To date, of the at least 71 genetic loci shown by conventional and molecular cytogenetic analysis to be involved in rearrangements with $11 \mathrm{q} 23$, where the $M L L$ gene is located, 64 could be molecularly characterized and the respective fusion partner cloned (Table 7) (Meyer et al., 2006; Meyer et al., 2009; Park et al., 2009). 
Table 7. Identified $M L L$ fusion partners

\begin{tabular}{|c|c|c|c|c|}
\hline No. & Cytogenetic abnormality & Breakpoint & Partner gene & Leukaemia type \\
\hline 1 & $\mathrm{t}(1 ; 11)(\mathrm{p} 32 ; \mathrm{q} 23)$ & $1 \mathrm{p} 32$ & EPS15/AF1P & ALL, AML, CML \\
\hline 2 & $t(1 ; 11)(q 21 ; q 23)$ & $1 q 21$ & $M L L T 11 / A F 1 Q$ & AML \\
\hline 3 & $\mathrm{t}(2 ; 11)(\mathrm{q} 11.2 \sim q 12 ; q 23)$ & $2 q 11.2 \sim q 12$ & AFF3/LAF4 & ALL \\
\hline 4 & $t(3 ; 11)(p 21 ; q 23)$ & $3 p 21$ & NCKIPSDIAF3P21 & $\mathrm{t}-\mathrm{AML}$ \\
\hline 5 & $\mathrm{t}(3 ; 11)(\mathrm{p} 21.3 ; \mathrm{q} 23)$ & $3 p 21.3$ & $D C P 1 A$ & ALL \\
\hline 6 & $\mathrm{t}(3 ; 11)(\mathrm{q} 21.3 ; \mathrm{q} 23)$ & $3 q 21.3$ & EEFSEC/SELB & ALL \\
\hline 7 & $\mathrm{t}(3 ; 11)(\mathrm{q} 24 ; \mathrm{q} 23)$ & $3 q 24$ & GMPS & $\mathrm{t}-\mathrm{AML}$ \\
\hline 8 & $\mathrm{t}(3 ; 11)(\mathrm{q} 27 \sim q 28 ; q 23)$ & $3 q 27 \sim q 28$ & $L P P$ & $\mathrm{t}-\mathrm{AML}$ \\
\hline 9 & $\mathrm{t}(4 ; 11)(\mathrm{p} 12 ; \mathrm{q} 23)$ & $4 p 12$ & FRYL & t-ALL, t-AML \\
\hline 10 & $\mathrm{t}(4 ; 11)(\mathrm{q} 21.1 ; \mathrm{q} 23)$ & $4 q 21.1$ & SEPT11/FLJ10849 & $\mathrm{CML}$ \\
\hline 11 & $\mathrm{t}(4 ; 11)(\mathrm{q} 21 ; \mathrm{q} 23)$ & $4 q 21$ & AFF1/AF4 & ALL, t-ALL, AML \\
\hline 12 & $\mathrm{t}(4 ; 11)(\mathrm{q} 35.1 ; \mathrm{q} 23)$ & $4 q 35.1$ & SORBS2/ARGBP2 & AML \\
\hline 13 & complex abnormalities & $5 q 12.3$ & CENPKIFKSG14 & AML \\
\hline 14 & ins $(5 ; 11)(q 31 ; q 13 q 23)$ & $5 q 31$ & AFF4/AF5Q31 & ALL \\
\hline 15 & $\mathrm{t}(5 ; 11)(\mathrm{q} 31 ; \mathrm{q} 23)$ & $5 q 31$ & ARHGAP26/GRAF & JMML \\
\hline 16 & $\mathrm{t}(6 ; 11)(\mathrm{q} 12 \sim 13 ; q 23)$ & $6 q 12 \sim q 13$ & SMAP1 & AML \\
\hline 17 & $\mathrm{t}(6 ; 11)(\mathrm{q} 15 ; \mathrm{q} 23)$ & $6 q 15$ & CASP8AP2 & AML \\
\hline 18 & $t(6 ; 11)(q 21 ; q 23)$ & $6 q 21$ & FOXO3/AF6Q21 & $\mathrm{t}-\mathrm{AML}$ \\
\hline 19 & $\mathrm{t}(6 ; 11)(\mathrm{q} 27 ; \mathrm{q} 23)$ & $6 q 27$ & MLLT4/AF6 & AML, t-AML, ALL \\
\hline 20 & $\mathrm{t}(7 ; 11)(\mathrm{p} 22.1 ; \mathrm{q} 23)$ & $7 p 22.1$ & TNRC18/KIAA1856 & ALL \\
\hline 21 & $\mathrm{t}(9 ; 11)(p 22 ; q 23)$ & $9 p 22$ & MLLT3/AF9 & AML, t-AML, ALL \\
\hline 22 & $\mathrm{t}(9 ; 11)(\mathrm{q} 33.1 \sim \mathrm{q} 33.3 ; \mathrm{q} 23)$ & $9 q 33.1 \sim q 33.3$ & DAB2IPIAF9Q34 & AML \\
\hline 23 & $\operatorname{ins}(11 ; 9)(q 23 ; q 34) \operatorname{inv}(11)(q 13 q 23)$ & $9 q 34$ & FNBP1/FBP17 & AML \\
\hline 24 & $\mathrm{t}(9 ; 11)(q 31 \sim q 34 ; q 23)$ & $9 q 31 \sim q 34$ & LAMC3 & $\mathrm{t}-\mathrm{AML}$ \\
\hline 25 & $\mathrm{t}(10 ; 11)(\mathrm{p} 11.2 ; \mathrm{q} 23)$ & $10 \mathrm{p} 11.2$ & $A B \mid 1$ & AML \\
\hline 26 & $\operatorname{ins}(10 ; 11)(p 12 ; q 23 q 13)$ & 10p12 & MLLT10/AF10 & AML, t-AML, ALL \\
\hline 27 & ins(10;11)(p12;q23) & $10 \mathrm{p} 12$ & $N E B L$ & AML \\
\hline 28 & $\mathrm{t}(10 ; 11)(\mathrm{q} 21 ; \mathrm{q} 23)$ & $10 q 21$ & TET1/LCX & AML \\
\hline 29 & $\operatorname{inv}(11)(p 15.3 q 23)$ & $11 \mathrm{p} 15.3$ & NRIP3 & AML \\
\hline 30 & $\mathrm{t}(11 ; 11)(\mathrm{q} 13.4 ; \mathrm{q} 23)$ & $11 q 13.4$ & ARHGEF17 & AML \\
\hline 31 & $\operatorname{inv}(11)(q 13.4 q 23)$ & $11 \mathrm{q} 13.4$ & C2CD3/DKFZP586P0123 & AML \\
\hline 32 & $\operatorname{inv}(11)(q 14 q 23)$ & $11 q 14$ & PICALMICALM & AML \\
\hline 33 & $\operatorname{inv(11)(q21q23)~}$ & $11 q 21$ & MAML2 & t-T-ALL, t-AML \\
\hline 34 & $\mathrm{t}(11 ; 15)(\mathrm{q} 23 \mathrm{q} ; \mathrm{q} 21) \operatorname{inv}(11)(\mathrm{q} 23 \mathrm{q} 23)$ & $11 \mathrm{q} 23$ & UBE $4 A$ & MDS \\
\hline 35 & $\operatorname{del}(11)(q 23 q 23.3)$ & $11 \mathrm{q} 23.3$ & ARHGEF12/LARG & AML \\
\hline 36 & $\operatorname{del}(11)(q 23 q 23.3)$ & $11 \mathrm{q} 23.3$ & $C B L$ & AML \\
\hline 37 & $\operatorname{del}(11)(q 23 q 23.3)$ & $11 \mathrm{q} 23.3$ & $B C L 9 L$ & ALL \\
\hline 38 & $\operatorname{del}(11)(q 23 q 24.2)$ & $11 q 24.2$ & TIRAP & AML \\
\hline 39 & $\operatorname{del}(11)(q 23 q 24.2)$ & $11 \mathrm{q} 24.2$ & $D C P S$ & AML \\
\hline 40 & $\mathrm{t}(11 ; 12)(\mathrm{q} 23 ; \mathrm{q} 13.2)$ & $12 q 13.2$ & CIP29 & AML \\
\hline 41 & $\mathrm{t}(11 ; 14)(\mathrm{q} 23.3 ; \mathrm{q} 23.3)$ & $14 q 23.3$ & GPHN & AML, t-AML \\
\hline 42 & $\mathrm{t}(11 ; 14)(\mathrm{q} 32.33 ; q 32.33)$ & $14 q 32.33$ & KIAA0284 & AML \\
\hline 43 & $\mathrm{t}(11 ; 15)(q 23 ; q 14)$ & $15 q 14$ & CASC5/AF15Q14 & AML, ALL \\
\hline 44 & $t(11 ; 15)(q 23 ; q 14)$ & $15 q 14$ & ZFYVE19/MPFYVE & AML \\
\hline 45 & $t(11 ; 16)(q 23 ; p 13.3)$ & $16 \mathrm{p} 13.3$ & CREBBP/CBP & t-MDS, t-AML, t-ALL \\
\hline
\end{tabular}




$\begin{array}{cccc}\mathrm{t}(11 ; 17)(\mathrm{q} 23 ; \mathrm{p} 13.1) & 17 \mathrm{p} 13.1 & \text { GAS7 } & \mathrm{t}-\mathrm{AML} \\ \mathrm{ins}(11 ; 17)(\mathrm{q} 23 ; \mathrm{q} 21) & 17 \mathrm{q} 21 & \text { ACACA } & \mathrm{AML} \\ \mathrm{t}(11 ; 17)(\mathrm{q} 23 ; \mathrm{q} 21) & 17 \mathrm{q} 21 & \text { MLLT6/AF17 } & \mathrm{AML} \\ \mathrm{t}(11 ; 17)(\mathrm{q} 23 ; \mathrm{q} 11 \sim \mathrm{q} 21.3) & 17 \mathrm{q} 11 \sim \mathrm{q} 21.3 & \text { LASP1 } & \mathrm{AML} \\ \mathrm{t}(11 ; 17)(\mathrm{q} 23 ; \mathrm{q} 25) & 17 \mathrm{q} 25 & \text { SEPT9/AF17Q25 } & \mathrm{t}-\mathrm{AML}, \mathrm{AML} \\ \mathrm{t}(11 ; 19)(\mathrm{q} 23 ; \mathrm{p} 13.1) & 19 \mathrm{p} 13.1 & \text { ELL } & \mathrm{AML}, \mathrm{t}-\mathrm{AML} \\ \mathrm{t}(11 ; 19)(\mathrm{q} 23 ; \mathrm{p} 13) & 19 \mathrm{p} 13.3 & \text { SH3GL1/EEN } & \mathrm{AML} \\ \mathrm{ins}(11 ; 19)(\mathrm{q} 23 ; \mathrm{p} 13.2) & 19 \mathrm{p} 13.2 & \text { VAV1 } & \mathrm{AML} \\ \mathrm{t}(11 ; 19)(\mathrm{q} 23 ; \mathrm{p} 13.3) & 19 \mathrm{p} 13.3 & \text { MLLT1/ENL } & \mathrm{ALL}, \mathrm{AML}, \mathrm{t}-\mathrm{AL} \\ \mathrm{t}(11 ; 19)(\mathrm{q} 23 ; \mathrm{p} 13.3) & 19 \mathrm{p} 13.3 & \text { ASAH3/ACER1 } & \mathrm{ALL} \\ \mathrm{t}(2 ; 11 ; 19)(\mathrm{p} 23.3 ; \mathrm{q} 23 ; \mathrm{p} 13.3) & 19 \mathrm{p} 13.3 & \text { LOC100128568 } & \mathrm{AML} \\ \mathrm{t}(11 ; 19)(\mathrm{q} 23 ; \mathrm{p} 13.3 \sim \mathrm{p} 13.2) & 19 \mathrm{p} 13.3 \sim \mathrm{p} 13.2 & \text { MYO1F } & \mathrm{AML} \\ \mathrm{t}(11 ; 19)(\mathrm{q} 23 ; \mathrm{q} 13) & 19 \mathrm{q} 13 & \text { ACTN4 } & \mathrm{ALL} \\ \mathrm{t}(11 ; 20)(\mathrm{q} 23 ; \mathrm{q} 11) & 20 \mathrm{q} 11 & \text { MAPRE1 } & \mathrm{ALL} \\ \mathrm{t}(11 ; 22)(\mathrm{q} 23 ; \mathrm{q} 11.21) & 22 \mathrm{q} 11.21 & \text { SEPT5/CDCREL } & \mathrm{AML}, \mathrm{T}-\mathrm{ALL} \\ \mathrm{t}(11 ; 22)(\mathrm{q} 23 ; \mathrm{q} 13.2) & 22 \mathrm{q} 13.2 & \text { EP3OO/P300 } & \mathrm{t}-\mathrm{AML} \\ \mathrm{t}(\mathrm{X} ; 11)(\mathrm{q} 13.1 ; \mathrm{q} 23) & \mathrm{Xq13.1} & \text { FOXO4/AFX } & \mathrm{ALL}, \mathrm{AML} \\ \mathrm{ins}(\mathrm{X} ; 11)(\mathrm{q} 24 ; \mathrm{q} 23) & \mathrm{Xq24} & \text { SEPT6 } & \mathrm{AML} \\ \operatorname{ins}(11 ; \mathrm{X})(\mathrm{q} 23 ; \mathrm{q} 28 \mathrm{q} 13.1) & \mathrm{Xq28} & \text { FLNA } & \mathrm{AML}\end{array}$

Gene symbols presented according with the Human Gene Nomenclature Committee (HUGO). AML (acute myeloid leukaemia), CML (chronic myeloid leukaemia), t-AML (therapy-related acute myeloid leukaemia), ALL (acute lymphoblastic leukaemia), MDS (myelodysplastic syndrome), JMML (juvenile myelomonocytic leukaemia), t-ALL (therapy-related acute lymphoblastic leukaemia), t-CML (therapy-related chronic myeloid leukaemia), t-AL (therapy-related acute leukaemia). Gene symbols presented according with the Human Gene Nomenclature Committee (HUGO).

The most frequent rearrangements, accounting for about $85 \%$ of all $M L L-$ rearranged cases, are $\mathrm{t}(4 ; 11)(\mathrm{q} 21 ; \mathrm{q} 23)$ involving the $A F F 1(A F 4)$ gene, $\mathrm{t}(9 ; 11)(\mathrm{p} 22 ; \mathrm{q} 23)$ involving the MLLT3 (AF9) gene, $\mathrm{t}(11 ; 19)(\mathrm{q} 23 ; \mathrm{p} 13.3)$ involving the MLLT1 (ENL) gene, $\mathrm{t}(10 ; 11)(\mathrm{p} 12 ; \mathrm{q} 23)$ involving the $M L L T 10(A F 10)$ gene and $\mathrm{t}(6 ; 11)(\mathrm{q} 27 ; \mathrm{q} 23)$ involving the MLLT4 (AF6) gene, respectively (Figure 9) (Meyer et al., 2006; Meyer et al., 2009). Of these, the most frequent both in paediatric and adult leukaemia patients is the chromosomal translocation $\mathrm{t}(4 ; 11)(\mathrm{q} 21 ; \mathrm{q} 23)$ (Meyer et al., 2006; Meyer et al., 2009). The $\mathrm{t}(4 ; 11)$ chromosomal translocation is particularly interesting since it has been found both in utero and in neonatal blood (Ford et al., 1993). 

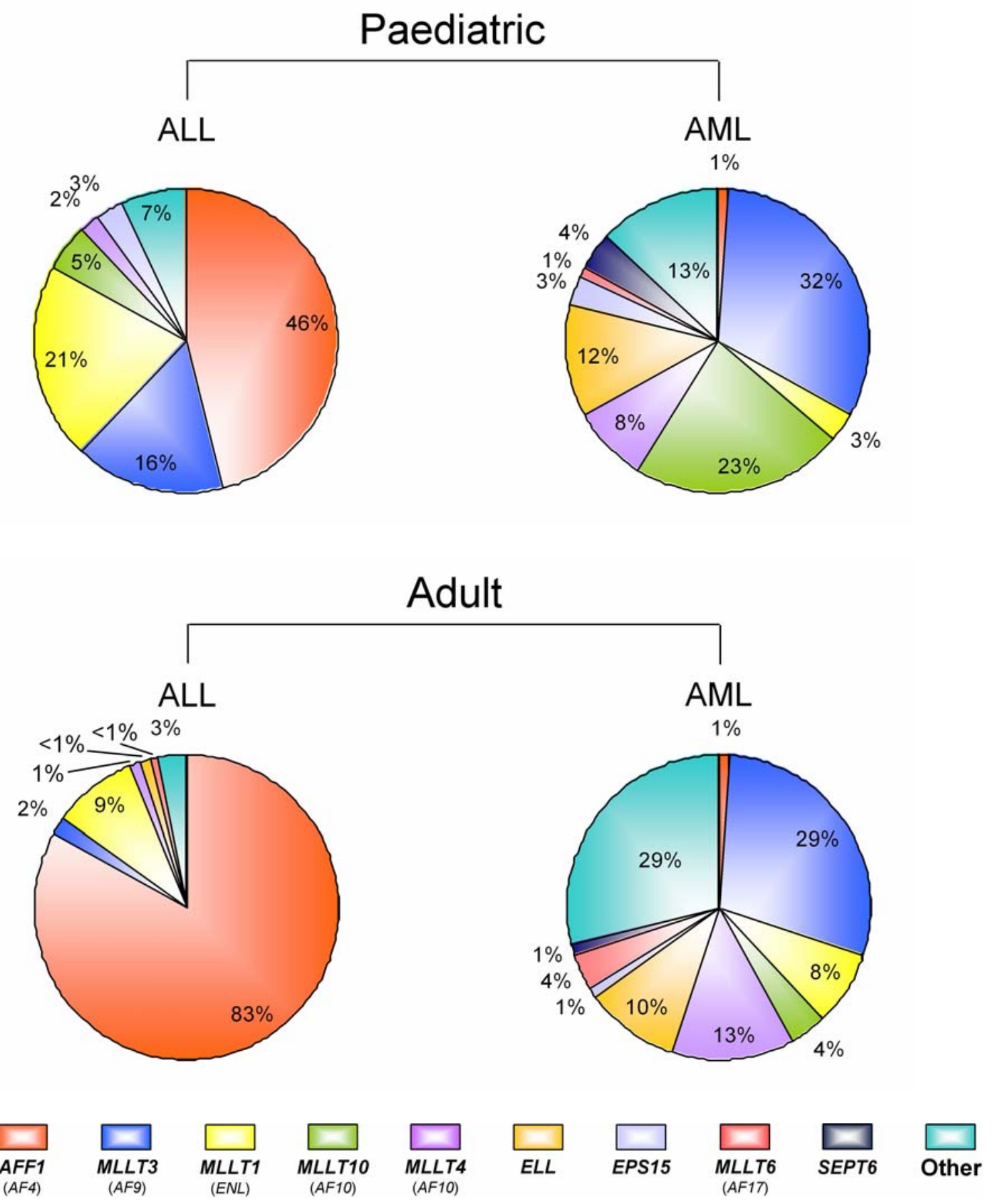

Figure 9. Distribution of the most frequent $M L L$ fusion partner genes in de novo childhood and adult leukaemias. Data compiled from Meyer et al., 2006; Krivtsov and Armstrong, 2007, Meyer et al., 2009. 
Moreover, in studies of mono-zygotic twins with concordant leukaemia, the identical chromosomal fusions were present prenatally, at birth and at the time of leukaemia presentation (Ford et al., 1993; Greaves et al., 2003). These twin studies are informative in terms of (i) prenatal origin, (ii) the initiating role of the chromosomal translocation, (iii) the need of secondary events, due to variable latency and heterogeneity of acquired secondary genetic alterations and (iv) impact and penetrance of the initiating genomic lesion. As infant ALL has a very fast onset, it can be assumed that the MLLAFF1 (MLL-AF4) translocation has a strong tumourigenic effect and may be sufficient for infant ALL.

MLL fusion partners can be classified into five distinct categories (Table 8). The first category, which accounts for most of $M L L$-rearranged leukaemias, includes fusions with nuclear proteins [(e.g. AFF1 (AF4), MLLT3 (AF9), MLLT10 (AF10), and MLLT1 (ENL)] (Meyer et al., 2006; Meyer et al., 2009). A second group comprises fusions with cytoplasmatic proteins such as GAS7, SH3GL1, EPS15, MLLT4 (AF6) and FOXO4, which may possess coiled-coil oligomerization domains that are important for their transformation potential (So et al., 2003; So and Cleary, 2003). A third group includes fusions with five of the fourteen known septin family members (SEPT2, SEPT5, SEPT6, SEPT9 and SEPT11; see below) involved in rearrangements with the MLL gene, making the septins the protein family most frequently involved in $M L L$-related leukaemia (Megonigal et al., 1998; Osaka et al., 1999; Taki et al., 1999; Ono et al., 2002; Kojima et al., 2004; Cerveira et al., 2006). 
Table 8. Classification of $M L L$ fusion partner genes

\begin{tabular}{|c|c|c|c|}
\hline Group & Putative function & $\begin{array}{l}\text { Fusion } \\
\text { partner }\end{array}$ & Frequency \\
\hline \multirow[t]{5}{*}{1} & Nuclear, putative DNA-binding proteins & $A F F 1(A F 4)$ & $\begin{array}{l}>80 \% \text { of } M L L- \\
\text { associated leukaemias }\end{array}$ \\
\hline & & MLLT3 (AF9) & \\
\hline & & $M L L T 1(E N L)$ & \\
\hline & & MLLT10 (AF10) & \\
\hline & & $E L L$ & \\
\hline \multirow[t]{5}{*}{2} & $\begin{array}{l}\text { Cytoplasm, presence of coiled-coil } \\
\text { oligomerization domain }\end{array}$ & EPS15 & $>10 \%$ \\
\hline & & GAS7 & \\
\hline & & SH3GL1 & \\
\hline & & MLLT4 (AF6) & \\
\hline & & FOXO4 & \\
\hline \multirow[t]{5}{*}{3} & $\begin{array}{l}\text { Cytoplasm, septin family, interact with } \\
\text { cytoskeletal filaments, have a role in mitosis }\end{array}$ & SEPT2 & $>1 \%$ \\
\hline & & SEPT5 & \\
\hline & & SEPT6 & \\
\hline & & SEPT9 & \\
\hline & & SEPT11 & \\
\hline \multirow[t]{2}{*}{4} & Nuclear, histone acetyltransferases & CREBBP & $>1 \%$ \\
\hline & & P300 & \\
\hline 5 & $\begin{array}{l}\text { MLL partial tandem duplication of } \\
\text { exons } 5-11(M L L-P T D)\end{array}$ & - & $\begin{array}{l}4-7 \% \text { of all AML with } \\
\text { normal karyotype }\end{array}$ \\
\hline
\end{tabular}

Adapted from Krivtsov and Armstrong (2007). Gene symbols presented according with the Human Gene Nomenclature Committee (HUGO).

Although the precise functions of septins remain unclear, current data suggest that they coordinate changes in cytoskeletal and membrane organization by acting as 
scaffolds that recruit factors to precise sites in a cell and/or as barriers that segregate membrane areas into discrete domains (Gladfelter and Montagna, 2007; Weirich et al., 2008). A fourth group includes the histone acetyltransferases EP300 (Ida et al., 1997) and CREBBP (Taki et al., 1997). MLL fusions with these proteins retain histone acetyltransferase activity of either CREBBP or EP300 (Krivtsov and Armstrong, 2007). Finally, the fifth type of rearrangements involving the $M L L$ gene is the partial tandem duplication of exons 5-12 (see above).

Significant progress has been made toward a detailed knowledge of the MLL recombinome in the last 16 years since the initial $M L L$ chromosomal breakpoints were cloned. During this period, of the at least 71 genetic loci known to be involved in rearrangements with 11q23, 64 were cloned and molecularly characterized. However, at least $32 \mathrm{MLL}$ fusion partners affected by chromosomal translocations remain to be identified (Table 9). Their identification and functional analysis may contribute to a better understanding of $M L L$-mediated leukaemogenesis and, at the end, may help to classify the large variety of different $M L L$ translocations into different risk groups, allowing a better stratification and treatment of patients with this type of leukaemia. 
Table 9. Cytogenetic localization of not yet identified $M L L$ fusion partners

\section{No. Cytogenetic abnormality Fusion partner Breakpoint Leukaemia type}

\begin{tabular}{|c|c|c|c|}
\hline 1 & $t(1 ; 11)(p 36 ; q 23)$ & $1 p 36$ & AML \\
\hline 2 & $\mathrm{t}(1 ; 11)(\mathrm{q} 31 ; \mathrm{q} 23)$ & $1 q 31$ & AML \\
\hline 3 & $\mathrm{t}(1 ; 11)(\mathrm{q} 32 ; \mathrm{q} 23)$ & $1 q 32$ & t-AML, AML \\
\hline 4 & $\mathrm{t}(2 ; 11)(\mathrm{p} 21 ; \mathrm{q} 23)$ & $2 \mathrm{p} 21$ & AML, ALL, MDS \\
\hline 5 & $\mathrm{t}(3 ; 11)(\mathrm{p} 13 ; q 23)$ & $3 p 13$ & AML \\
\hline 6 & $\mathrm{t}(4 ; 11)(\mathrm{p} 11 ; \mathrm{q} 23)$ & $4 p 11$ & t-AML \\
\hline 7 & $\mathrm{t}(6 ; 11)(\mathrm{q} 13 ; \mathrm{q} 23)$ & $6 q 13$ & AML \\
\hline 8 & $\mathrm{t}(7 ; 11)(\mathrm{p} 15 ; \mathrm{q} 23)$ & $7 p 15$ & CML, AML \\
\hline 9 & $\mathrm{t}(7 ; 11)(\mathrm{q} 22 ; \mathrm{q} 23)$ & $7 q 22$ & ALL, AML \\
\hline 10 & $\mathrm{t}(7 ; 11)(\mathrm{q} 32 ; \mathrm{q} 23)$ & $7 q 32$ & Not characterized \\
\hline 11 & $\mathrm{t}(8 ; 11)(\mathrm{q} 11 ; \mathrm{q} 23)$ & $8 q 11$ & Not characterized \\
\hline 12 & $\mathrm{t}(8 ; 11)(\mathrm{q} 21 ; \mathrm{q} 23)$ & $8 q 21$ & $\mathrm{AL}$ \\
\hline 13 & $\mathrm{t}(8 ; 11)(\mathrm{q} 24 ; \mathrm{q} 23)$ & $8 q 24$ & AML \\
\hline 14 & $\mathrm{t}(9 ; 11)(\mathrm{p} 11 ; \mathrm{q} 23)$ & $9 p 11$ & ALL \\
\hline 15 & $\mathrm{t}(10 ; 11)(q 25 ; q 23)$ & $10 q 25$ & AML \\
\hline 16 & $\mathrm{t}(11 ; 11)(\mathrm{q11;q23)}$ & $11 q 11$ & ALL, CLL \\
\hline 17 & $t(11 ; 12)(q 23 ; p 13)$ & $12 \mathrm{p} 13$ & t-AML, AML, ALL \\
\hline 18 & $\mathrm{t}(11 ; 12)(q 23 ; q 13)$ & $12 q 13$ & AML, CLL \\
\hline 19 & $\mathrm{t}(11 ; 12)(\mathrm{q} 23 ; \mathrm{q} 24)$ & $12 q 24$ & AML \\
\hline 20 & $\mathrm{t}(4 ; 13 ; 11)(\mathrm{q} 21 ; \mathrm{q} 34 ; \mathrm{q} 23)$ & $13 q 34$ & ALL, AML \\
\hline 21 & $\mathrm{t}(11 ; 14)(q 23 ; q 11)$ & $14 q 11$ & ALL \\
\hline 22 & $t(11 ; 15) q 23 ; q 15)$ & $15 q 15$ & AML \\
\hline 23 & $\mathrm{t}(11 ; 17)(q 23 ; q 11)$ & $17 q 11$ & AML \\
\hline 24 & $\mathrm{t}(11 ; 17)(\mathrm{q} 23 ; \mathrm{q} 23)$ & $17 q 23$ & AML \\
\hline 25 & $\mathrm{t}(11 ; 18)(q 23 ; q 12)$ & $18 q 12$ & $\mathrm{AML}, \mathrm{CML}$ \\
\hline 26 & $\mathrm{t}(11 ; 18)(\mathrm{q} 23 ; \mathrm{q} 23)$ & $18 q 23$ & AML, t-AML \\
\hline 27 & $\mathrm{t}(11 ; 20)(q 23 ; q 13)$ & $20 q 13$ & ALL, AML \\
\hline 28 & $\mathrm{t}(11 ; 21)(q 23 ; q 11)$ & $21 q 11$ & MDS, ALL \\
\hline 29 & $\mathrm{t}(\mathrm{Y} ; 11)(\mathrm{p} 11 ; \mathrm{q} 23)$ & Yp11 & AML \\
\hline 30 & $\mathrm{t}(X ; 11)(\mathrm{q} 22 ; \mathrm{q} 23)$ & Xq22 & AML \\
\hline 31 & ins $(11 ; X)(q 23 ; q 28)$ & Xq28) & AML \\
\hline 32 & $\operatorname{ins}(X ; 11)(q 26.3 ; q 23)$ & Xq26.3 & $\mathrm{AL}$ \\
\hline
\end{tabular}

Gene symbols presented according with the Human Gene Nomenclature Committee (HUGO). AML (acute myeloid leukaemia), t-AML (therapy-related acute myeloid leukaemia), ALL (acute lymphoblastic leukaemia), MDS (myelodysplastic syndrome), CML (chronic myeloid leukaemia), AL (acute leukaemia), CLL (chronic lymphocytic leukaemia). 


\section{References}

ACS (American Cancer Society). Cancer Facts \& Figures 2008. American Cancer Society: Atlanta, USA, 2008.

Armstrong SA, Staunton JE, Silverman LB, Pieters R, den Boer ML, Minden MD, Sallan SE, Lander ES, Golub TR, Korsmeyer SJ. MLL translocations specify a distinct gene expression profile that distinguishes a unique leukemia. Nat Genet 2002; 30:41-47.

Ayton PM, Cleary ML. Molecular mechanisms of leukemogenesis mediated by MLL fusion proteins. Oncogene 2001; 20:5695-5707.

Ayton PM, Cleary ML. Transformation of myeloid progenitors by MLL oncoproteins is dependent on Hoxa7 and Hoxa9. Genes Dev 2003; 17:2298-2307.

Baldus CD, Thiede C, Soucek S, Bloomfield CD, Thiel E, Ehninger G. BAALC expression and FLT3 internal tandem duplication mutations in acute myeloid leukemia patients with normal cytogenetics: prognostic implications. J Clin Oncol 2006; 24:790-797.

Barjesteh van Waalwijk van Doorn-Khosrovani S, Erpelinck C, Meijer J, et al. Biallelic mutations in the CEBPA gene and low CEBPA expression levels as prognostic markers in intermediate-risk AML. Hematol J 2003; 4:31-40.

Basecke J, Whelan JT, Griesinger F, Bertrand FE. The MLL partial tandem duplication in acute myeloid leukaemia. $\mathrm{Br} J$ Haematol 2006; 135:438-449.

Bennett $\mathrm{JH}$. Case of hypertrophy of the spleen and liver in which death took place from suppuration of the blood. Edinb Med Surg J 1845; 64: 413-423.

Bennett JM, Catovsky D, Daniel MT, Flandrin G, Galton DA, Gralnick HR, Sultan C. Proposals for the classification of the acute leukaemias. French-American-British (FAB) co-operative group. Br J Haematol 1976; 33:451-458.

Bennett JM, Catovsky D, Daniel MT, Flandrin G, Galton DA, Gralnick HR, Sultan C. Proposed revised criteria for the classification of acute myeloid leukemia. A report of the French-American-British Cooperative Group. Ann Intern Med 1985; 103:620-625. 
Beyer V, Mühlematter D, Parlier V, Cabrol C, Bougeon-Mamin S, Solenthaler M, Tobler A, Pugin P, Gregor M, Hitz F, Hess U, Chapuis B, Laurencet F, Schanz U, Schmidt PM, van Melle G, Jotterand M. Polysomy 8 defines a clinico-cytogenetic entity representing a subset of myeloid hematologic malignancies associated with a poor prognosis: report on a cohort of 12 patients and review of 105 published cases. Cancer Genet Cytogenet 2005; 160:97-119.

Biondi, A., Cimino, G., Pieters, R. \& Pui, C. H. Biological and therapeutic aspects of infant leukemia. Blood 2000; 96:24-33.

Bowen DT, Frew ME, Hills R, Gale RE, Wheatley K, Groves MJ, Langabeer SE, Kottaridis PD, Moorman AV, Burnett AK, Linch DC. RAS mutation in acute myeloid leukemia is associated with distinct cytogenetic subgroups but does not influence outcome in patients <60 yrs. Blood 2005; 106:2113-2119.

Briggs SD, Bryk M, Strahl BD, Cheung WL, Davie JK, Dent SY, Winston F, Allis CD. Histone $\mathrm{H} 3$ lysine 4 methylation is mediated by Set1 and required for cell growth and DNA silencing in Saccharomyces cerevisiae. Genes Dev 2001; 15:3286-3295.

Brownson RC, Novotny TE, Perry MC. Cigarette smoking and adult leukemia. A metaanalysis. Arch Intern Med 1993; 153:469-475.

Bullinger L, Döhner K, Bair E, Fröhling S, Schlenk RF, Tibshirani R, Döhner H, Pollack JR. Use of gene-expression profiling to identify prognostic subclasses in adult acute myeloid leukemia. N Engl J Med 2004; 350:1605-1616.

Byrd JC, Mrózek K, Dodge RK, Carroll AJ, Edwards CG, Arthur DC, Pettenati MJ, Patil SR, Rao KW, Watson MS, Koduru PR, Moore JO, Stone RM, Mayer RJ, Feldman EJ, Davey FR, Schiffer CA, Larson RA, Bloomfield CD. Pretreatment cytogenetic abnormalities are predictive of induction success, cumulative incidence of relapse, and overall survival in adult patients with de novo acute myeloid leukemia: results from Cancer and Leukemia Group B (CALGB 8461). Blood 2002; 100:4325-4336. 
Caligiuri MA, Strout MP, Schichman SA, Mrózek K, Arthur DC, Herzig GP, Baer MR, Schiffer CA, Heinonen K, Knuutila S, Nousiainen T, Ruutu T, Block AW, Schulman P, Pedersen-Bjergaard J, Croce CM, Bloomfield CD. Partial tandem duplication of ALL1 as a recurrent molecular defect in acute myeloid leukemia with trisomy 11. Cancer Res 1996; 56:1418-1425.

Cairoli R, Beghini A, Grillo G, Nadali G, Elice F, Ripamonti CB, Colapietro P, Nichelatti M, Pezzetti L, Lunghi M, Cuneo A, Viola A, Ferrara F, Lazzarino M, Rodeghiero F, Pizzolo G, Larizza L, Morra E. Prognostic impact of c-KIT mutations in core binding factor leukemias: an Italian retrospective study. Blood 2006; 107:3463-3468.

Cammenga J, Horn S, Bergholz U, Sommer G, Besmer P, Fiedler W, Stocking C. Extracellular KIT receptor mutants, commonly found in core binding factor AML, are constitutively active and respond to imatinib mesylate. Blood 2005; 106:3958-3961.

Cardis E, Gilbert FS, Carpenter L, Howe G, Kato I, Armstrong BK, Beral V, Cowper G, Douglas A, Fix J, Fry SA, Kaldor J, Lave C, Salmon L, Smith PG, Voelz GL, Wiggs LD. Effects of low doses and low dose rates of external ionizing radiation: cancer mortality among nuclear industry workers in three countries, Radiat Res 1995; 142:117-132.

Care RS, Valk PJ, Goodeve AC, Abu-Duhier FM, Geertsma-Kleinekoort WM, Wilson GA, Gari MA, Peake IR, Löwenberg B, Reilly JT. Incidence and prognosis of C-KIT and FLT3 mutations in core-binding factor (CBF) acute myeloid leukaemias. Br J Haematol 2003; 121:775-777.

Caslini C, Yang Z, El-Osta M, Milne TA, Slany RK, Hess JL. Interaction of MLL amino terminal sequences with menin is required for transformation. Cancer Res 2007; 67:7275-7283.

Cerveira N, Correia C, Bizarro S, Pinto C, Lisboa S, Mariz JM, Marques M, Teixeira MR. SEPT2 is a new fusion partner of MLL in acute myeloid leukemia with $t(2 ; 11)(q 37 ; q 23)$. Oncogene 2006; 25:6147-6152.

Chen CS, Sorensen PH, Domer PH, Reaman GH, Korsmeyer SJ, Heerema NA, Hammond GD, Kersey JH. Molecular rearrangements on chromosome 11q23 predominate in infant acute lymphoblastic leukemia and are associated with specific biologic variables and poor outcome. Blood 1993; 81:2386-2393. 
Creutzig U, Ritter J, Vormoor J, Ludwig WD, Niemeyer C, Reinisch I, Stollmann-Gibbels B, Zimmermann M, Harbott J. Myelodysplasia and acute myelogenous leukemia in Down's syndrome. A report of 40 children of the AML-BFM Study Group. Leukemia 1996; 10:1677-1686.

Daser A, Rabbitts TH. The versatile mixed lineage leukaemia gene MLL and its many associations in leukaemogenesis. Semin Cancer Biol 2005; 15:175-188.

Dash A, Gilliland DG. Molecular genetics of acute myeloid leukaemia. Best Pract Res Clin Haematol 2001; 14:49-64.

Davico L, Sacerdote C, Ciccone G, Pegoraro L, Kerim S, Ponzio G, Vineis P. Chromosme 8, occupational exposures, smoking, and acute nonlymphocytic leukemias: a popultionbased study. Cancer Epidemiol Biomarkers Prev 1998; 7:1123-1125.

De Klein A, van Kessel AG, Grosveld G et al. A cellular oncogene is translocated to the Philadelphia chromosome in chronic myelocytic leukemia. Nature 1982; 300:765-767.

DiMartino JF, Miller T, Ayton PM, Landewe T, Hess JL, Clearly ML, Shilatifard A. A carboxy-terminal domain of ELL is required and sufficient for immortalization of myeloid progenitors by MLL-ELL. Blood 2000; 96:3887-3893.

DiMartino JF, Ayton PM, Chen EH, Naftzger CC, Young BD, Clearly ML. The AF10 leucine zipper is required for leukemic transformation of myeloid progenitors by MLLAF10. Blood 2002; 99:3780-3785.

Dou Y, Milne TA, Tackett AJ, Smith ER, Fukuda A, Wysocka J, Allis CD, Chait BT, Hess $\mathrm{JL}$, Roeder RG. Physical association and coordinate function of the H3 K4 methyltransferase MLL1 and the H4 K16 acetyltransferase MOF. Cell 2005; 121:873885.

Downing JR. The core-binding factor leukemias: lessons learned from murine models. Curr Opin Genet Dev 2003; 13:48-54.

Ebstein W: Über die acute Leukämie und Pseudoleukämie. Dtsch Arch Klin Med 1889; 44:343. 
Egger G, Liang G, Aparicio A, Jones PA. Epigenetics in human disease and prospects for epigenetic therapy. Nature 2004; 429:457-463.

Ehrlich P. Methodologische beitrage zur physiologie und pathologie der verschisdenen formen der leukocyten. Zeitschrift Klin Med 1880; 1:553-558.

Ehrlich P. Uber die bedeutung der neutrophilen kornung. Charite Annales 1887; 12:288295.

Ernst P, Wang J, Huang M, Goodman RH, Korsmeyer SJ. MLL and CREB bind cooperatively to the nuclear coactivator CREB-binding protein. Mol Cell Biol 2001; 21:2249-2258.

Espey DK, Wu XC, Swan J, Wiggins C, Jim MA, Ward E, Wingo PA, Howe HL, Ries LA, Miller BA, Jemal A, Ahmed F, Cobb N, Kaur JS, Edwards BK. Annual report to the nation on the status of cancer, 1975-2004, featuring cancer in American Indians and Alaska Natives. Cancer 2007; 110:2119-2152.

Estey E, Döhner H. Acute myeloid leukaemia. Lancet 2006; 368:1894-1907.

Fair K, Anderson M, Bulanova E, Mi H, Tropschug M, Diaz MO. Protein interactions of the MLL PHD fingers modulate MLL target gene regulation in human cells. Mol Cell Biol $2001 ; 21: 3589-3597$.

Felix CA, Hosler MR, Winick NJ, Masterson M, Wilson AE, Lange BJ. ALL-1 gene rearrangements in DNA topoisomerase II inhibitor-related leukemia in children. Blood $1995 ; 85: 3250-3256$.

Ferlay J, Autier P, Boniol M, Heanue M, Colombet M, Boyle P. Estimates of the cancer incidence and mortality in Europe in 2006. Ann Oncol 2007; 18:581-592.

Ferlay J, Bray F, Pisani P, Parkin DM. GLOBOCAN 2002 - Cancer incidence, mortality and prevalence worldwide. IARC Cancer Base N 5, Version 2. IARC Press: Lyon 2004.

Ferrando AA, Look AT. Gene expression profiling in T-cell acute lymphoblastic leukemia. Semin Hematol 2003; 40:274-280. 
Ford AM, Ridge SA, Cabrera ME, Mahmoud H, Steel CM, Chan LC, Greaves M. In utero rearrangements in the trithorax-related oncogene in infant leukaemias. Nature 1993; 27:358-360.

Ford CE, Jacobs PA, Lajtha LG. Human somatic chromosomes. Nature 1958; 181:15651568.

Friedreich N. Ein neuer fall von Leukämie. Virchows Arch Path Anat 1857; 12:37-58.

Fröhling S, Scholl C, Gilliland DG, Levine RL. Genetics of myeloid malignancies: pathogenetic and clinical implications. J Clin Oncol 2005; 23:6285-6295.

Garcia M, Jemal A, Ward EM, Center MM, Hao Y, Siegel RL, Thun MJ. Global Cancer Facts \& Figures 2007. American Cancer Society: Atlanta 2007.

Gladfelter AS, Montagna C. Seeking truth on Monte Verita. Workshop on the molecular biology and biochemistry of septins and septin function. EMBO Rep 2007; 8:1120-1126.

Greaves MF, Maia AT, Wiemels JL, Ford AM. Leukemia in twins: lessons in natural history. Blood 2003; 102:2321-2333.

Grier DG, Thompson A, Kwasniewska A, McGonigle GJ, Halliday HL, Lappin TR. The pathophysiology of HOX genes and their role in cancer. J Pathol 2005; 205:154-171.

Grimwade D, Walker H, Oliver F, Wheatley K, Harrison C, Harrison G, Rees J, Hann I, Stevens R, Burnett A, Goldstone A. The importance of diagnostic cytogenetics on outcome in AML: analysis of 1,612 patients entered into the MRC AML 10 trial. The Medical Research Council Adult and Children's Leukaemia Working Parties. Blood 1998; 92:2322-2333.

Harris NL, Jaffe ES, Diebold J, Flandrin G, Muller-Hermelink HK, Vardiman J, Lister TA, Bloomfield CD. The World Health Organization classification of neoplastic diseases of the hematopoietic and lymphoid tissues. Report of the Clinical Advisory Committee meeting, Airlie House, Virginia, November, 1997. Ann Oncol 1999; 10:1419-1432.

Hasle $\mathrm{H}$. Pattern of malignant disorders in individuals with Down's syndrome. Lancet Oncol 2001; 2:429-436. 
Henderson ES. History of leukemia. In: Henderson ES, Lister TA, Greaves MF, editors. Leukemia. WB Saunders: Philadelphia, USA, 1996.

Hess JL. MLL: a histone methyltransferase disrupted in leukemia. Trends Mol Med 2004; 10:500-507.

Hsieh JJ, Cheng EH, Korsmeyer SJ. Taspase1: a threonine aspartase required for cleavage of MLL and proper HOX gene expression. Cell 2003a; 115 :293-303.

Hsieh JJ, Ernst P, Erdjument-Bromage H, Tempst P, Korsmeyer SJ. Proteolytic cleavage of MLL generates a complex of $\mathrm{N}$ - and C-terminal fragments that confers protein stability and subnuclear localization. Mol Cell Biol 2003b; 23:186-194.

Hsu K, Look AT. Turning on a dimer: new insights into MLL chimeras. Cancer Cell 2003; 4:81-83

Huret JL, Dessen P, Bernheim A. An atlas of chromosomes in hematological malignancies. Example: 11q23 and MLL partners. Leukemia 2001; 15:987-989.

Ida K, Kitabayashi I, Taki T, Taniwaki M, Noro K, Yamamoto M, Ohki M, Hayashi Y. Adenoviral $\mathrm{E} 1 \mathrm{~A}$-associated protein $\mathrm{p} 300$ is involved in acute myeloid leukemia with $\mathrm{t}(11 ; 22)(\mathrm{q} 23 ; \mathrm{q} 13)$. Blood 1997; 90:4699-4704.

Jemal A, Siegel R, Ward E, Hao Y, Xu J, Murray T, Thun MJ. Cancer statistics, 2008. CA Cancer J Clin 2008; 58:71-96.

Jude C, Climer L, Xu D, Artinger E, Fisher J, Ernst P. Unique and independent roles for MLL in adult hematopoietic stem cells and progenitors. Cell Stem Cell 2007; 1:324-337.

Kane EV, Roman E, Cartwright R, Parker J, Morgan G. Tobacco and the risk of acute leukaemia in adults. Br J Cancer 1999; 81:1228-1233.

Kato H, Schull WJ. Studies of the mortality of A-bomb survivors. 7. Mortality, 1950-1978: Part I. Cancer mortality. Radiat Res 1982; 90:395-432.

Kelly LM, Gilliland DG. Genetics of myeloid leukemias. Annu Rev Genomics Hum Genet 2002; 3:179-198. 
Kojima K, Sakai I, Hasegawa A, Niiya H, Azuma T, Matsuo Y, Fuji N, Tanimoto M, Fujita S. FLJ10849, a septin family gene, fuses $M L L$ in a novel leukemia cell line CNLBC1 derived from chronic neutrophilic leukemia in transformation with $t(4 ; 11)(q 21 ; q 23)$. Leukemia 2004; 18:998-1005.

Kosmider O, Moreau-Gachelin F. From mice to human: the "two-hit model" of leukemogenesis. Cell Cycle 2006; 5:569-570.

Kratz CP, Antonietti L, Shannon KM, Dole MG, Friebert SE. Acute myeloid leukemia associated with $\mathrm{t}(8 ; 21)$ or trisomy 8 in children with neurofibromatosis, type 1. J Pediatr Hematol Oncol 2003; 25:343.

Krivtsov AV, Armstrong SA. MLL translocations, histone modifications and leukaemia stem-cell development. Nat Rev Cancer 2007; 7:823-833.

Kumar AR, Hudson WA, Chen W, Nishiuchi R, Yao Q, Kersey JH. Hoxa9 influences the phenotype but not the incidence of Mll-AF9 fusion gene leukemia. Blood 2004; 103:1823-1828.

Largaespada DA, Brannan Cl, Shaughnessy JD, Jenkins NA, Copeland NG. The neurofibromatosis type 1 (NF1) tumor suppressor gene and myeloid leukemia. Curr Top Microbiol Immunol 1996; 211:233-239.

Leone G, Pagano L, Ben-Yehuda D, Voso MT. Therapy-related leukemia and myelodysplasia: susceptibility and incidence. Haematologica 2007; 92:1389-1398.

Levine EG, Bloomfield CD. Leukemias and myelodysplastic syndromes secondary to drug, radiation, and environmental exposure. Semin Oncol 1992; 19:47-84.

Li ZY, Liu DP, Liang CC. New insight into the molecular mechanisms of MLL-associated leukemia. Leukemia 2005; 19:183-190.

Lindgren V, Rowley JD. Comparable complex rearrangements involving 8;21 and 9;22 translocations in leukaemia. Nature 1977; 266:744-745.

Liu H, Takeda S, Cheng EH, Hsieh JJ. Biphasic MLL takes helm at cell cycle control: implications in human mixed lineage leukemia. Cell Cycle 2008; 7:428-435. 
Lo-Coco F, Ammatuna E, Montesinos P, Sanz MA. Acute promyelocytic leukemia: recent advances in diagnosis and management. Semin Oncol 2008; 35:401-409.

Löchner K, Siegler G, Führer M, Greil J, Beck JD, Fey GH, Marschalek R.. A specific deletion in the breakpoint cluster region of the ALL1 gene is associated with acute lymphoblastic T-cell leukemias. Cancer Res 1996; 56:2171-2177.

Luca DC, Almanaseer IY. Simultaneous presentation of multiple myeloma and acute monocytic leukemia. Arch Pathol Lab Med 2003; 127:1506-1508.

Marcucci G, Baldus CD, Ruppert AS, Radmacher MD, Mrózek K, Whitman SP, Kolitz JE, Edwards CG, Vardiman JW, Powell BL, Baer MR, Moore JO, Perrotti D, Caligiuri MA, Carroll AJ, Larson RA, de la Chapelle A, Bloomfield CD. Overexpression of the ETSrelated gene, ERG, predicts a worse outcome in acute myeloid leukaemia with normal karyotype: a Cancer and Leukemia Group B study. J Clin Oncol 2005; 23:9234-9242.

Martin ME, Milne TA, Bloyer S, Galoian K, Shen W, Gibbs D, Brock HW, Slany R, Hess JL. Dimerization of MLL fusion proteins immortalizes hematopoietic cells. Cancer Cell 2003; 4:197-207.

McMahon KA, Samantha Y.-L. Hiew, Hadjur S, Veiga-Fernandes H, Menzel U, Price AJ, Kioussis D, Williams O, Brady HJM. MLL has a critical role in fetal and adult hematopoietic stem cell self-renewal. Cell Stem Cell 2007; 1:338-345.

Megonigal MD, Rappaport EF, Jones DH, Williams TM, Lovett BD, Kelly KM, Lerou PH, Moulton T, Budarf ML, Felix CA. t(11;22)(q23;q11.2) in acute myeloid leukemia of infant twins fuses MLL with hCDCrel, a cell division cycle gene in the genomic region of deletion in DiGeorge and velocardiofacial syndromes. Proc Natl Acad Sci USA 1998; 95:6413-6418.

Meyer C, Schneider B, Jakob S, Strehl S, Attarbaschi A, Schnittger S, Schoch C, Jansen MW, van Dongen JJ, den Boer ML, Pieters R, Ennas MG, Angelucci E, Koehl U, Greil J, Griesinger F, Zur Stadt U, Eckert C, Szczepański T, Niggli FK, Schäfer BW, Kempski H, Brady HJ, Zuna J, Trka J, Nigro LL, Biondi A, Delabesse E, Macintyre E, Stanulla M, Schrappe M, Haas OA, Burmeister T, Dingermann T, Klingebiel T, Marschalek R. The MLL recombinome of acute leukemias. Leukemia 2006; 20:777-784. 
Meyer C, Kowarz E, Hofmann J, Renneville A, Zuna J, Trka J, Ben Abdelali R, Macintyre E, De Braekeleer E, De Braekeleer M, Delabesse E, de Oliveira MP, Cavé H, Clappier E, van Dongen JJ, Balgobind BV, van den Heuvel-Eibrink MM, Beverloo HB, PanzerGrümayer R, Teigler-Schlegel A, Harbott J, Kjeldsen E, Schnittger S, Koehl U, Gruhn B, Heidenreich O, Chan LC, Yip SF, Krzywinski M, Eckert C, Möricke A, Schrappe M, Alonso CN, Schäfer BW, Krauter J, Lee DA, Zur Stadt U, Te Kronnie G, Sutton R, Izraeli S, Trakhtenbrot L, Lo Nigro L, Tsaur G, Fechina L, Szczepanski T, Strehl S, llencikova D, Molkentin M, Burmeister T, Dingermann T, Klingebiel T, Marschalek R. New insights to the MLL recombinome of acute leukemias. Leukemia 2009; 23:1490-1499.

Milne TA, Briggs SD, Brock HW, Martin ME, Gibbs D, Allis CD, Hess JL. MLL targets SET domain methyltransferase activity to Hox gene promoters. Mol Cell 2002; 10:1107-1117.

Mitelman F, Johansson B, Mertens F. The impact of translocations and gene fusions on cancer causation. Nat Rev Cancer 2007; 7:233-245.

Moloney WC. Radiogenic leukemia revisited. Blood 1987; 70:905-908.

Moorman AV, Roman E, Cartwright RA, Morgan GJ. Smoking and the risk of acute myeloid leukaemia in cytogenetic subgroups. Br J Cancer 2002; 86:60-62.

Moreau-Gachelin F. Lessons from models of murine erythroleukemia to acute myeloid leukemia (AML): proof-of-principle of co-operativity in AML. Haematologica 2006; 91:1644-1652.

Morris SW, Kirstein MN, Valentine MB, Dittmer KG, Shapiro DN, Saltman DL, Look AT.. Fusion of a kinase gene, ALK, to a nucleolar protein gene, NPM, in non-Hodgkin's lymphoma. Science 1994; 263:1281-1284.

Mrózek K, Bloomfield CD. Chromosome aberrations, gene mutations and expression changes, and prognosis in adult acute myeloid leukemia. Hematology Am Soc Hematol Educ Program 2006: 169-77.

Mrózek K, Heinonen K, Lawrence D, Carroll AJ, Koduru PR, Rao KW, Strout MP, Hutchison RE, Moore JO, Mayer RJ, Schiffer CA, Bloomfield CD. Adult patients with de novo acute myeloid leukemia and $t(9 ; 11)(p 22 ; q 23)$ have a superior outcome to patients 
with other translocations involving band 11q23: a cancer and leukemia group B study. Blood 1997; 90:4532-4538.

Mrózek K, Marcucci G, Paschka P, Bloomfield CD. Advances in molecular genetics and treatment of core-binding factor acute myeloid leukemia. Curr Opin Oncol 2008; 20:711718.

Mrózek K, Marcucci G, Paschka P, Whitman SP, Bloomfield CD. Clinical relevance of mutations and gene-expression changes in adult acute myeloid leukemia with normal cytogenetics: are we ready for a prognostically prioritized molecular classification? Blood 2007; 109:431-448.

Mullis K, Faloona F, Scharf S, Saiki R, Horn G, Erlich H. Specific enzymatic amplification of DNA in vitro: The polymerase chain reaction. Cold Spring Harb Symp Quant Biol 1986; 51:263-273.

Muntean AG, Giannola D, Udager AM, Hess JL. The PHD fingers of MLL block MLL fusion protein-mediated transformation. Blood 2008; 112:4690-4693.

Naegeli O. Uber rothes knockenmark und myeloblasten. Dtsch Med Wschr 1900; 18:287290.

Najean Y, Rain JD. Treatment of polycythemia vera: use of 32P alone or in combination with maintenance therapy using hydroxyurea in 461 patients greater than 65 years of age. The French Polycythemia Study Group. Blood 1997: 89:2319-2327.

Nakamura T, Mori T, Tada S, Krajewski W, Rozovskaia T, Wassell R, Dubois G, Mazo A, Croce CM, Canaani E. ALL-1 is a histone methyltransferase that assembles a supercomplex of proteins involved in transcriptional regulation. Mol Cell 2002; 10:11191128.

Nakanishi M, Tanaka K, Shintani T, Takahashi T, Kamada N. Chromosomal instability in acute myelocytic leukemia and myelodysplastic syndrome patients among atomic bomb survivors. J Radiat Res 1999; 40:159-167.

Neumann E. Ueber die bedeutung des knockenmarkes fur die blutbilding. Ein beitrag zur entwicklungsgeschichte der blutkorperchen. Arch Heilk 1869; 10:68-102. 
Neumann E. Ein fall von Leukamie mit erkrankung des knochenmarks. Arch Heilk 1870; 11:1.

Nowell PC. Phytohemagglutinin: An initiator of mitosis in cultures of normal human leukocytes. Cancer Res 1960; 20:462-466.

Nowell PC, Hungerford DA. A minute chromosome in human granulocytic leukemia. Science 1960; 132:1497.

Ono R, Taki T, Taketani T, Kawaguchi H, Taniwaki M, Okamura T, Kawa K, Hanada R, Kobayashi M, Hayashi Y. SEPTIN6, a human homologue to mouse Septin6, is fused to $M L L$ in infant acute myeloid leukemia with complex chromosomal abnormalities involving 11q23 and Xq24. Cancer Res 2002; 62:333-337.

Osaka M, Rowley JD, Zeleznik-Le NJ. MSF (MLL septin-like fusion), a fusion partner gene of MLL, in a therapy-related acute myeloid leukemia with a $t(11 ; 17)(q 23 ; q 25)$. Proc Natl Acad Sci USA 1999; 96:6428-6433.

Park TS, Lee SG, Song J, Lee KA, Kim J, Choi JR, Lee ST, Marschalek R, Meyer C. CASP8AP2 is a novel partner gene of MLL rearrangement with $t(6 ; 11)(q 15 ; q 23)$ in acute myeloid leukemia. Cancer Genet Cytogenet 2009; 195:94-95.

Paschka P. Core binding factor acute myeloid leukemia. Semin Oncol 2008; 35:410-417.

Piller G. Leukaemia: a brief historical review from ancient times to 1950. Br J Haematol 2001; 112:282-292.

Pineault N, Helgason CD, Lawrence HJ, Humphries RK. Differential expression of Hox, Meis1, and $\mathrm{Pbx} 1$ genes in primitive cells throughout murine hematopoietic ontogeny. Exp Hematol 2002; 30:49-57.

Pinheiro PS, Tyczyński JE, Bray F, Amado J, Matos E, Parkin DM. Cancer incidence and mortality in Portugal. Eur J Cancer 2003; 39:2507-2520.

Pogoda JM, Preston-Martin S, Nichols PW, Ross RK. Smoking and the risk of acute myeloid leukemia: results from a Los Angeles County case-control study, Am J Epidemiol 2002; 155:646-653. 
Popovic R, Zeleznik-Le NJ. MLL: how complex does it get? J Cell Biochem 2005; 95:234242.

Poppe B, Van Limbergen H, Van Roy N, Vandecruys E, De Paepe A, Benoit Y, Speleman F. Chromosomal aberrations in Bloom syndrome patients with myeloid malignancies. Cancer Genet Cytogenet 2001; 128:39-42.

Preudhomme C, Sagot C, Boissel N, et al. Favorable prognostic significance of CEBPA mutations in patients with de novo acute myeloid leukemia: a study from the Acute Leukemia French Association (ALFA). Blood 2002; 100:2717-2723.

Pui $\mathrm{CH}$, Relling MV. Topoisomerase II inhibitor-related acute myeloid leukaemia. $\mathrm{Br} \mathrm{J}$ Haematol 2000; 109:13-23.

Redner RL, Rush EA, Faas S, Rudert WA, Corey SJ. The $t(5 ; 17)$ variant of acute promyelocytic leukaemia expresses a nucleophosmin-retinoic acid receptor fusion. Blood 1996; 87:882-886.

Renneville A, Roumier C, Biggio V, Nibourel O, Boissel N, Fenaux P, Preudhomme C. Cooperating gene mutations in acute myeloid leukemia: a review of the literature. Leukemia 2008; 22:915-931.

Richardson C, Jasin M. Frequent chromosomal translocations induced by DNA doublestrand breaks. Nature 2000; 405:697-700.

RORENO (Registo Oncológico Regional do Norte). Registo Oncológico Nacional 2001. Instituto Português de Oncologia do Porto FG, Portugal, 2008.

Rozovskaia T, Ravid-Amir O, Tillib S, Getz G, Feinstein E, Agrawal H, Nagler A, Rappaport EF, Issaeva I, Matsuo Y, Kees UR, Lapidot T, Lo Coco F, Foa R, Mazo A, Nakamura T, Croce CM, Cimino G, Domany E, Canaani E. Expression profiles of acute lymphoblastic and myeloblastic leukemias with ALL-1 rearrangements. Proc Natl Acad Sci USA 2003; 100:7853-7858.

Rowley JD. A new consistent chromosome abnormality in chronic myelogenous leukemia identified by quinacrine fluorescence and Giemsa staining. Nature 1973; 243:290-293. 
Rubnitz JE, Gibson B, Smith FO. Acute myeloid leukemia. Pediatr Clin North Am 2008; $55: 21-51$.

Rubnitz JE, Raimondi SC, Tong X, Srivastava DK, Razzouk BI, Shurtleff SA, Downing JR, Pui $\mathrm{CH}$, Ribeiro RC, Behm FG. Favorable impact of the $t(9 ; 11)$ in childhood acute myeloid leukemia. J Clin Oncol 2002; 20:2302-2309.

Sandler DP, Shore DL, Anderson JR, Davey FR, Arthur D, Mayer RJ, Silver RT, Weiss RB, Moore JO, Schiffer CA. Cigarette smoking and the risk of acute leukemia: associations with morphology and cytogenetic abnormalities in bone marrow. $\mathrm{J}$ Natl Cancer Inst 1993: 85:1994-2003.

Sahin FI, Kizilkilic E, Bulakbasi T, Yilmaz Z, Boga C, Ozalp O, Karakus S, Ozdogu H. Cytogenetic findings and clinical outcomes of adult acute myeloid leukaemia patients. Clin Exp Med 2007; 7:102-107.

Sanger F, Coulson AR. A rapid method for determining sequences in DNA by primed synthesis with DNA polymerase. J Mol Biol 1975; 94:441-448.

Savitz DA, Andrews KW. Review of epidemiologic evidence on benzene and lymphatic and hematopoietic cancers. Am J Ind Med 1997; 31:287-95.

Schichman SA, Caligiuri MA, Gu Y, Strout MP, Canaani E, Bloomfield CD, Croce CM.. ALL1 partial duplication in acute leukemia. Proc Natl Acad Sci USA 1994; 91:62366239.

Schnittger S, Kohl TM, Haferlach T, Kern W, Hiddemann W, Spiekermann K, Schoch C. KIT-D816 mutations in AML1-ETO positive AML are associated with impaired event-free and overall survival. Blood 2006; 107:1791-1799.

Schnittger S, Wörmann B, Hiddemann W, Griesinger F. Partial tandem duplications of the MLL gene are detectable in peripheral blood and bone marrow of nearly all healthy donors. Blood 1998; 92:1728-1734.

Shu XO, Ross JA, Pendergrass TW, Reaman GH, Lampkin B, Robison LL. Parental alcohol consumption, cigarette smoking, and risk of infant leukemia: a Childrens Cancer Group study. J Natl Cancer Inst 1996; 88:24-31. 
Slany RK. When epigenetics kills: MLL fusion proteins in leukemia. Hematol Oncol 2005; 23:1-9.

Slovak ML, Kopecky KJ, Cassileth PA, Harrington DH, Theil KS, Mohamed A, Paietta E, Willman CL, Head DR, Rowe JM, Forman SJ, Appelbaum FR. Karyotypic analysis predicts outcome of preremission and postremission therapy in adult acute myeloid leukemia: a Southwest Oncology Group/Eastern Cooperative Oncology Group Study. Blood 2000; 96:4075-4083.

Smith SM, Le Beau MM, Huo D, Karrison T, Sobecks RM, Anastasi J, Vardiman JW, Rowley JD, Larson RA. Clinical-cytogenetic associations in 306 patients with therapyrelated myelodysplasia and myeloid leukemia: the University of Chicago series. Blood 2003; 102:43-52.

Snyder R. Benzene and leukemia. Crit Rev Toxicol 2002; 32:155-210.

Snyder R, Kalf GF. A perspective on benzene leukemogenesis. Crit Rev Toxicol 1994; 24:177-209.

So CW, Cleary ML. Common mechanism for oncogenic activation of MLL by forkhead family proteins. Blood 2003; 101:633-639.

So CW, Cleary ML. Dimerization: a versatile switch for oncogenesis. Blood 2004; 104:919-922.

So CW, Karsunky H, Wong P, Weissman IL, Cleary ML. Leukemic transformation of hematopoietic progenitors by MLL-GAS7 in the absence of Hoxa7 or Hoxa9. Blood 2004; 103:3192-3199.

So CW, Lin M, Ayton PM, Chen EH, Cleary ML. Dimerization contributes to oncogenic activation of MLL chimeras in acute leukemias. Cancer Cell 2003; 4:99-110.

Speck NA, Gilliland DG. Core-binding factors in haematopoiesis and leukaemia. Nat Rev Cancer 2002; 2:502-513.

Sterkers Y, Preudhomme C, Laï JL, Demory JL, Caulier MT, Wattel E, Bordessoule D, Bauters F, Fenaux P. Acute myeloid leukemia and myelodysplastic syndromes following 


\section{INTRODUCTION}

essential thrombocythemia treated with hydroxyurea: high proportion of cases with $17 p$ deletion. Blood 1998; 91:616-622.

Strehl S, Borkhardt A, Slany R, Fuchs UE, König M, Haas OA. The human LASP1 gene is fused to MLL in an acute myeloid leukemia with $t(11 ; 17)(q 23 ; q 21)$. Oncogene 2003; 22:157-160.

Strissel PL, Strick R, Rowley JD, Zeleznik-Le NJ. An in vivo topoisomerase II cleavage site and a DNase I hypersensitive site colocalize near exon 9 in the MLL breakpoint cluster region. Blood 1998; 92:3793-3803.

Taki T, Ohnishi H, Shinohara K, Sako M, Bessho F, Yanagisawa M, Hayashi Y. AF17q25, a putative septin family gene, fuses the MLL gene in acute myeloid leukemia with t(11;17)(q23;q25). Cancer Res 1999; 59:4261-4265.

Taki T, Sako M, Tsuchida M, Hayashi $Y$. The $t(11 ; 16)(q 23 ; p 13)$ translocation in myelodysplastic syndrome fuses the MLL gene to the CBP gene. Blood 1997; 89:39453950.

Tefferi A. The history of myeloproliferative disorders: before and after Dameshek. Leukemia 2008; 22:3-13.

Tefferi A, Thiele J, Vardiman JW. The 2008 World Health Organization classification system for myeloproliferative neoplasms: order out of chaos. Cancer 2009; 115:38423847.

Thirman MJ, Larson RA. Therapy-related myeloid leukemia. Hematol Oncol Clin North Am 1996; 10:293-320.

Thomas X. Highlights in the history of leukaemia - a historical review from the beginnings to current therapeutic developments. Haema 2006; 9:191-211

Tischkowitz M, Dokal I. Fanconi anaemia and leukaemia - clinical and molecular aspects. Br J Haematol 2004; 26:176-191.

Tjio JH, Levan A. The chromosome number in man. Hereditas 1956; 42:1-6. 
Toyota M, Kopecky KJ, Toyota MO, Jair KW, Willman CL, Issa JP. Methylation profi ling and acute myeloid leukemia. Blood 2001; 97:2823-2829.

Valk PJ, Bowen DT, Frew ME, Goodeve AC, Lowenberg B, Reilly JT. Second hit mutations in the RTK/RAS signaling pathway in acute myeloid leukemia with inv(16). Haematologica 2004b; 89:106.

Valk PJ, Verhaak RG, Beijen MA, Erpelinck CA, Barjesteh van Waalwijk van DoornKhosrovani S, Boer JM, Beverloo HB, Moorhouse MJ, van der Spek PJ, Löwenberg B, Delwel R. Prognostically useful gene-expression profiles in acute myeloid leukemia. $N$ Engl J Med 2004a; 350:1617-1628.

van Leeuwen FE. Risk of acute myelogenous leukaemia and myelodysplasia following cancer treatment. Baillieres Clin Haematol 1996; 9:57-85.

Vardiman JW, Thiele J, Arber DA, Brunning RD, Borowitz MJ, Porwit A, Harris NL, Le Beau MM, Hellstrom-Lindberg E, Tefferi A, Bloomfield CD. The 2008 revision of the WHO classification of myeloid neoplasms and acute leukemia: rationale and important changes. Blood 2009; 114:937-951.

Virchow R. Weisses Blut. Froriep's Notzien 1845; 36:151-156.

Vlachos A, Klein GW, Lipton JM. The Diamond Blackfan Anemia Registry: tool for investigating the epidemiology and biology of Diamond-Blackfan anemia. $J$ Pediatr Hematol Oncol 2001; 23:377-382.

von Muehlendahl KE. Chernobyl fallout, nuclear plants and leukaemia: review of recent literature. Eur J Pediatr 1998; 157:602-604.

Weirich CS, Erzberger JP, Barral Y. The septin family of GTPases: architecture and dynamics. Nat Rev Mol Cell Biol 2008; 9:478-489.

WHO classification of tumours of haematopoietic and lymphoid tissues. Swerdlow $\mathrm{SH}$, Campo E, Harris NL, Jaffe ES, Pileri SA, Stein H, Thiele J, Vardiman JW, editors. IARC Press: Lyon 2008. 
Wiernik PH. Leukemias and plasma cell myeloma. Cancer Chemother Biol Response Modif 1997; 17:390-407.

Yamamoto Y, Kiyoi H, Nakano Y, Suzuki R, Kodera Y, Miyawaki S, Asou N, Kuriyama K, Yagasaki F, Shimazaki C, Akiyama H, Saito K, Nishimura M, Motoji T, Shinagawa K, Takeshita A, Saito H, Ueda R, Ohno R, Naoe T. Activating mutation of D835 within the activation loop of FLT3 in human hematologic malignancies. Blood 2001; 97:24342439.

Yano T, Nakamura T, Blechman J, Sorio C, Dang CV, Geiger B, Canaani E. Nuclear punctate distribution of ALL-1 is conferred by distinct elements at the $\mathrm{N}$ terminus of the protein. Proc Natl Acad Sci USA 1997; 94:7286-7291.

Yeoh EJ, Ross ME, Shurtleff SA, Williams WK, Patel D, Mahfouz R, Behm FG, Raimondi SC, Relling MV, Patel A, Cheng C, Campana D, Wilkins D, Zhou X, Li J, Liu H, Pui CH, Evans WE, Naeve C, Wong L, Downing JR. Classification, subtype discovery, and prediction of outcome in pediatric acute lymphoblastic leukemia by gene expression profiling. Cancer Cell 2002; 1:133-143.

Yokota S, Kiyoi H, Nakao M, Iwai T, Misawa S, Okuda T, Sonoda Y, Abe T, Kahsima K, Matsuo Y, Naoe T. Internal tandem duplication of the FLT3 gene is preferentially seen in acute myeloid leukemia and myelodysplastic syndrome among various haematological malignancies.: a study on a large series of patients and cell lines. Leukemia 1997; 10:1605-1609.

Yokoyama A, Kitabayashi I, Ayton PM, Cleary ML, Ohki M. Leukemia proto-oncoprotein MLL is proteolytically processed into two fragments with opposite transcriptional properties. Blood 2002; 100:3710-3718.

Yokoyama A, Wang Z, Wysocka J, Sanyal M, Aufiero DJ, Kitabayashi I, Herr W, Cleary ML. Leukemia proto-oncoprotein MLL forms a SET1-like histone methyltransferase complex with menin to regulate Hox gene expression. Mol Cell Biol 2004 ; 24:56395649 .

Yoneda-Kato N, Look AT, Kirstein MN, Valentine MB, Raimondi SC, Cohen KJ, Carroll AJ, Morris SW.. The $\mathrm{t}(3 ; 5)(\mathrm{q} 25.1 ; \mathrm{q} 34)$ of myelodysplastic syndrome and acute myeloid leukemia produces a novel fusion gene, NPM-MLF1. Oncogene 1996; 12:265-275. 
Zeisig BB, Milne T, García-Cuéllar MP, Schreiner S, Martin ME, Fuchs U, Borkhardt A, Chanda SK, Walker J, Soden R, Hess JL, Slany RK. Hoxa9 and Meis1 are key targets for MLL-ENL-mediated cellular immortalization. Mol Cell Biol 2004; 24:617-628.

Zwaan MC, Reinhardt D, Hitzler J, Vyas P. Acute leukemias in children with Down syndrome. Pediatr Clin North Am 2008; 55:53-70. 
INTRODUCTION 
RATIONALE AND AIMS

RATIONALE AND AIMS 
RATIONALE AND AIMS 


\section{RATIONALE AND AIMS}

The work that led to this Thesis started as a research project entitled "Identification and characterisation of $M L L$ fusion partner genes in acute leukaemia patients", founded by the Associação Portuguesa Contra a Leucemia and by the Comissão de Fomento da Investigação em Cuidados de Saúde. At the time, the aims of this project were those discriminated below. However, as frequently occurs in a research setting, the path taken was influenced by the first results and by the new questions raised by them.

1. To identify novel $M L L$ fusion partners/variants in acute myeloid neoplasia cases where previous cytogenetic, fluorescent in situ hybridization (FISH), and/or molecular studies suggested the existence of not yet characterized $M L L$ rearrangements.

2. To perform a detailed molecular characterization at the RNA (exon) level of all the new MLL rearrangements/variants to identify all possible fusion and splice variants.

3. To perform, whenever possible, a detailed genomic breakpoint junction characterization of all novel $M L L$ rearrangements using bioinformatic approaches, aiming the identification of repetitive DNA sequence elements and motifs known to be associated with site specific recombination, cleavage, and gene rearrangement.

4. To identify possible shared characteristics between novel and known MLL fusion partners that can contribute to a better understanding of their role in $M L L$-mediated leukemogenesis.

5. To evaluate the deregulation of the mRNA expression levels of both $M L L$ and respective fusion partner as a mechanism relevant for the leukaemogenic process in MLL-related myeloid neoplasia.

6. To correlate the genetic findings with the clinical profile of the patients, aiming the identification of potential associations between certain molecular markers and patient characteristics. 
RATIONALE AND AIMS 


\section{MATERIAL AND METHODS, RESULTS AND DISCUSSION}


MATERIAL AND METHODS, RESULTS AND DISCUSSION 
MATERIAL AND METHODS, RESULTS AND DISCUSSION

1. Septins as MLL fusion partners in myeloid neoplasia 
MATERIAL AND METHODS, RESULTS AND DISCUSSION 
PAPER \#1

Nuno Cerveira, Cecília Correia, Susana Bizarro, Carla Pinto, Susana Lisboa, José M. Mariz, Margarida Marques, Manuel R. Teixeira

\section{SEPT2 IS A NEW FUSION PARTNER OF MLL IN ACUTE MYELOID LEUKAEMIA WITH t(2;11)(q37;q23)}

Oncogene, 25: 6147-6152, 2006 
MATERIAL AND METHODS, RESULTS AND DISCUSSION 
Oncogene (2006), 1-6

(c) 2006 Nature Publishing Group All rights reserved 0950-9232/06 $\$ 30.00$

www nature com/onc

\title{
ONCOGENOMICS
}

\section{$S E P T 2$ is a new fusion partner of $M L L$ in acute myeloid leukemia with $\mathrm{t}(2 ; 11)(\mathbf{q} 37 ; \mathbf{q} 23)$}

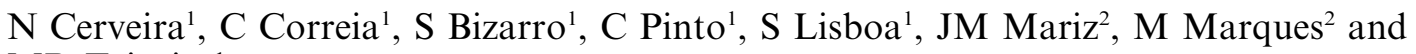 \\ MR Teixeira ${ }^{1}$
}

${ }^{1}$ Department of Genetics, Portuguese Oncology Institute, Porto, Portugal and ${ }^{2}$ Department of Onco-Hematology, Portuguese Oncology Institute, Porto, Portugal

\begin{abstract}
We have identified a new mixed lineage leukemia $(M L L)$ gene fusion partner in a patient with treatment-related acute myeloid leukemia (AML) presenting a $\mathbf{t}(2 ; 11)(\mathbf{q} 37 ; \mathbf{q} 23)$ as the only cytogenetic abnormality. Fluorescence in situ hybridization demonstrated a rearrangement of the $M L L$ gene and molecular genetic analyses identified a septin family gene, $S E P T 2$, located on chromosome $2 \mathrm{q} 37$, as the fusion partner of $M L L$. RNA and DNA analyses showed the existence of an in-frame fusion of $M L L$ exon 7 with $S E P T 2$ exon 3, with the genomic breakpoints located in intron 7 and 2 of $M L L$ and SEPT2, respectively. Search for DNA sequence motifs revealed the existence of two sequences with 94.4\% homology with the topoisomerase II consensus cleavage site in $M L L$ intron 7 and SEPT2 intron 2. $S E P T 2$ is the fifth septin family gene fused with $M L L$, making this gene family the most frequently involved in $M L L$-related AML (about $10 \%$ of all known fusion partners). The protein encoded by $S E P T 2$ is highly homologous to septins 1,4 and 5 and is involved in the coordination of several key steps of mitosis. Further studies are warranted to understand why the septin protein family is particularly involved in the pathogenesis of $M L L$-associated leukemia.
\end{abstract}

Oncogene advance online publication, 8 May 2006; doi:10.1038/sj.onc. 1209626

Keywords: $M L L-S E P T 2$; fusion oncogenes; $\mathrm{t}(2 ; 11)$ (q37;q23); therapy-related AML

The mixed lineage leukemia $(M L L)$ gene codes for a multi-domain molecule that is a major regulator of class I homeobox $(H O X)$ gene expression, directly interacting with HOX promoter regions (Milne et al., 2002; Nakamura et al., 2002). As $H O X$ genes play a key role in the regulation of hematopoietic development, it seems plausible that deregulation of $M L L$ activity might result in abnormal patterns of $H O X$ gene expression in

Correspondence: Dr MR Teixeira, Department of Genetics, Portuguese Oncology Institute, Rua Dr António Bernardino de Almeida, Porto 4200-072, Portugal.

E-mail: mteixeir@ipoporto.min-saude.pt

Received 3 January 2006; revised 7 March 2006; accepted 16 March 2006 hematopoietic stem cells or progenitors (Daser and Rabbitts, 2005; Li et al., 2005; Slany, 2005). Normally, $H O X$ expression is high in hematopoietic stem cells and becomes gradually extinguished during differentiation (Grier et al., 2005). A failure to downregulate $H O X$ expression inhibits hematopoietic maturation and can lead to leukemia (Grier et al., 2005).

Abnormalities of $11 \mathrm{q} 23$ involving the $M L L$ gene are found in several hematological malignancies, including acute lymphoblastic leukemia (ALL) and acute myeloid leukemia (AML) (Huret, 2005). The overall incidence of $M L L$-associated leukemia is around 3 and $8-10 \%$ for AML and ALL, respectively (Daser and Rabbitts, 2005). Rearrangements of $M L L$ can also be found in a proportion of patients with therapy-related leukemia after treatment with topoisomerase II inhibitors, such as anthracyclines (e.g. doxorubicin and epirubicin) and epipodophyllotoxins (e.g. etoposide and tenoposide) (Pui and Relling, 2000). The presence of an $M L L$ gene abnormality ( $M L L$ gene fusion or exon duplication) is associated with poor prognosis in ALL and is an intermediate prognostic factor in AML (Pui and Relling, 2000; Daser and Rabbitts, 2005; Li et al., 2005; Popovic and Zeleznik-Le, 2005; Slany, 2005).

One of the most notable features of $M L L$ is the extraordinary diversity of the fusion partners. To date, 71 different chromosome bands have been described to be rearranged with $11 \mathrm{q} 23$ and about 50 fusion genes have been cloned (Huret, 2005). The most common $M L L$ fusion partners are $A F 4$ (4q21), $A F 6$ (6q27), $A F 9$ (9p23), AF10 (10p12), ELL (19p13.1) and $E N L$ (19p13.3) (Nakamura et al., 2002; Daser and Rabbitts, 2005). The fusion genes encode chimeric proteins harboring the $\mathrm{NH}_{2}$-terminal amino acids of MLL and the COOH-terminal amino acids of the partner protein (Daser and Rabbitts, 2005; Li et al., 2005; Slany, 2005). The major contribution of the fusion partners investigated so far seems to be to convert the rearranged MLL protein to a potent transcriptional activator (Daser and Rabbitts, 2005). However, several $M L L$ fusion partners affected by chromosomal translocations have not yet been identified (Huret, 2005). In the present study, we have identified the $S E P T 2$ gene as a novel fusion partner of $M L L$ in a patient with treatment-related AML presenting a $\mathrm{t}(2 ; 11)(\mathrm{q} 37 ; \mathrm{q} 23)$ as the only cytogenetic abnormality. 
A 54-year-old female was diagnosed with a breast adenocarcinoma in 1987 (T2N0M0; treated with radical mastectomy) and with a contralateral breast adeno-
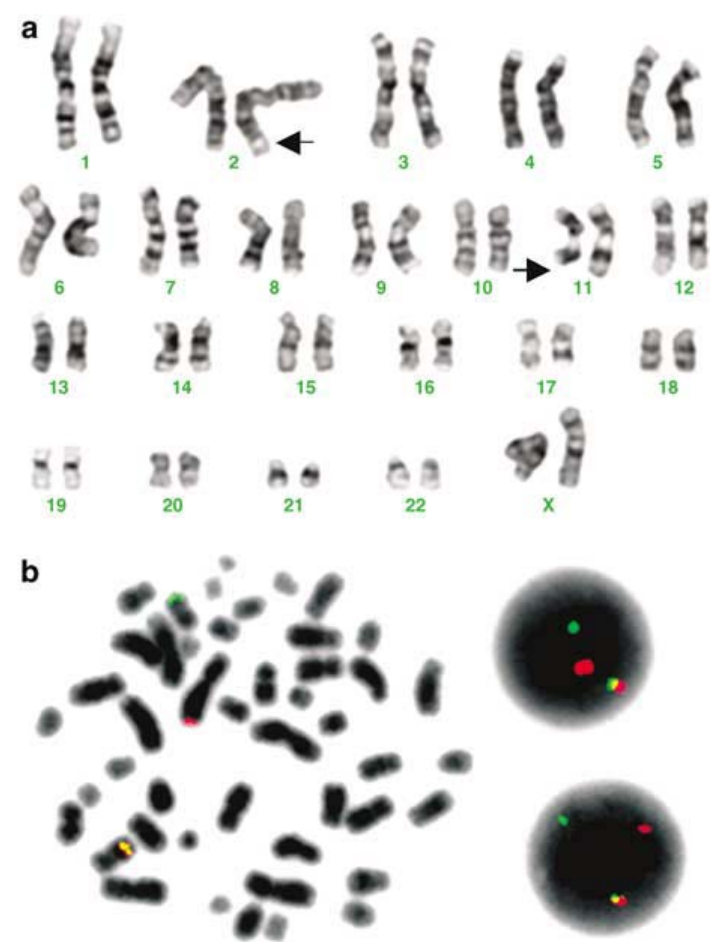

Figure 1 Cytogenetic and fluorescence in situ hybridization studies of the acute myeloid leukemia (AML) patient. (a) The diagnostic bone marrow sample showed a $t(2 ; 11)(\mathrm{q} 37 ; \mathrm{q} 23)$ as the sole chromosome abnormality, suggesting the involvement of the $M L L$ gene located at 11q23. Derivative chromosomes 2 and 11 are marked with arrows. The bone marrow sample was cultured for $24 \mathrm{~h}$ in RPMI 1640 medium with GlutaMAX-I (Invitrogen, London, UK) supplemented with $20 \%$ fetal bovine serum (Invitrogen, London, UK). Chromosome preparations were made by standard methods and banded by trypsin-Leishman. The karyotype was described according to the ISCN (1995) guidelines. (b) Fluorescence in situ hybridization demonstrated a split signal localized in the $\operatorname{der}(2)$ and $\operatorname{der}(11)$ chromosomes, confirming the break of the $M L L$ gene in the leukemic cells. Fluorescence in situ hybridization analysis was performed with LSI MLL dual-color, break-apart probe (Vysis, Downers Grove, IL, USA), according to the manufacturer's instructions. carcinoma in 2001 (T1N0M0; treated with radical mastectomy, followed by six courses of chemotherapy with 5-fluorouracil, epirubicin and cyclophosphamide). In 2004, this patient developed pancytopenia and the diagnosis of therapy-related AML was established (AML-M4 according to the French-American-British classification). Blood count was hemoglobin $8.4 \mathrm{~g} / \mathrm{dl}$, platelets $34 \times 10^{9} / 1$, and leukocytes $4.18 \times 10^{9} / 1$ with $2 \%$ circulating blasts. Bone marrow was infiltrated with $66.5 \%$ blasts. She was treated with two courses of chemotherapy (cytarabine, daunorubicin and cyclosporin), followed by an additional course of high-dose cytarabine and allogeneic bone marrow transplantation (BMT). The patient has no evidence of disease at the time of writing.

The bone marrow showed a $\mathrm{t}(2 ; 11)(\mathrm{q} 37 ; \mathrm{q} 23)$ as the only cytogenetic abnormality (Figure 1a), which suggested the involvement of the $M L L$ gene located in 11q23. Fluorescence in situ hybridization (FISH) analysis on bone marrow metaphases demonstrated the rearrangement of $M L L$, with the telomeric part of the gene being translocated to the der(2) (Figure 1b) Subsequent karyotype and FISH studies performed with 1-3 months intervals were normal, both before and after BMT.

The previous identification of four septin genes involved in rearrangements with the $M L L$ gene (Megonigal et al., 1998; Osaka et al., 1999; Taki et al., 1999a; Ono et al., 2002; Kojima et al., 2004), combined with a GenBank search of putatively expressed genes on chromosomal band $2 \mathrm{q} 37$, prompted us to hypothesize that the MLL fusion partner on 2q37 was SEPT2. Reverse transcription-polymerase chain reaction (RTPCR) with an antisense primer located on SEPT2 exon 9 and three MLL sense primers located on exons 5, 6 and 7 (Table 1) showed the presence of PCR fragments of 1233,956 , and $885 \mathrm{bp}$, respectively, suggestive of an $M L L-S E P T 2$ rearrangement resulting from fusion of $M L L$ exon 7 with $S E P T 2$ exon 3 (Figure 2a). Additional RT-PCR analysis with sense primers located on $M L L$ exons 7 and 8 and antisense primers located on SEPT2 exons 3 and 4 gave additional support to this hypothesis, as expected amplification fragments of 241 and $275 \mathrm{bp}$ were observed with the $M L L$ exon 7 primer and the SEPT2 antisense primers, but no amplification was detected with the $M L L$ exon 8 primer (Figure 2b).

Table 1 Sequence of the primers used for the RNA and DNA analyses

\begin{tabular}{|c|c|c|}
\hline Primer & Sequence & Position \\
\hline$M L L-E x 6 \mathrm{~S}$ & $5^{\prime}$-GCAAACAGAAAAAAGTGGCTCCCCG-3' & $4048-4072$ \\
\hline$M L L$-Ex8S & 5'-GCAGAAAATGTGTGGGAGATGGGAG-3' & $4254-4278$ \\
\hline SEPT2-Ex3AS & 5'-CCACCATCAGTGTGAACTCAAAAC-3' & $525-548$ \\
\hline$S E P T 2-\mathrm{Ex} 4 \mathrm{AS}$ & 5'-ATGAGAGTCGATTTTCCTAGACCTG-3' & $558-582$ \\
\hline SEPT2-EX9AS & $5^{\prime}$-GAGGCGGCCTCTGACCTTCT-3' & $1173-1192$ \\
\hline$S E P T 2-I n t 2 A S-2$ & 5'-CCCAGGTATTAGGTGCAATGC-3' & $1292-1312$ (SEPT2 intron 2) \\
\hline
\end{tabular}

Abbreviations: Ex, exon; Int, intron; S, sense; AS, antisense. 

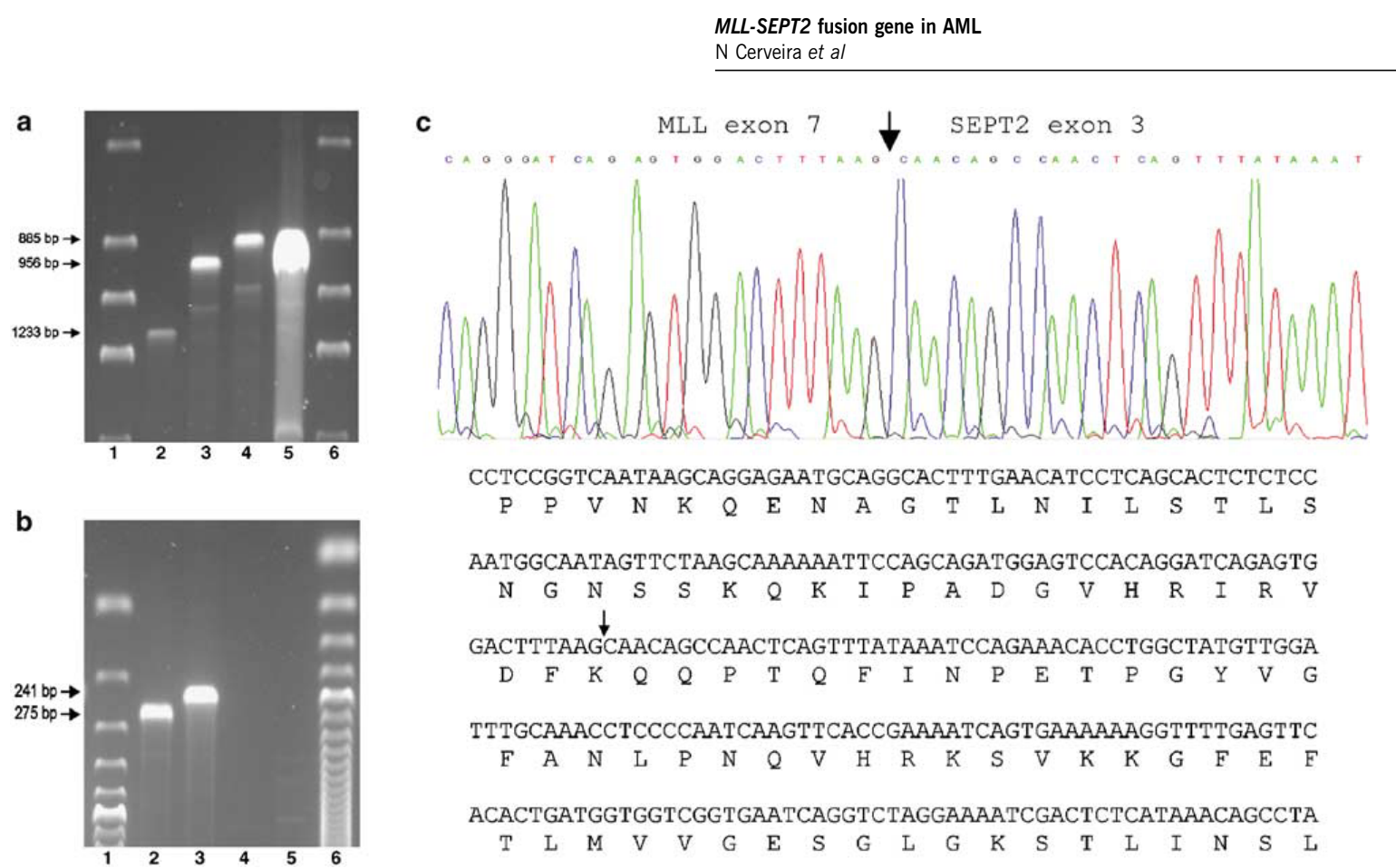

Figure 2 Detection and analysis of the $M L L-S E P T 2$ fusion transcript. (a) Reverse transcription-polymerase chain reaction (RTPCR) analysis with a SEPT2 antisense primer located in $S E P T 2$ exon 9 and three $M L L$ sense primers located in exons 5,6 and 7 (lanes $2-4$, respectively). Lane 5 shows re-amplification of lane 2 product with primers $M L L$-Ex7S and SEPT2-Ex9AS. Lanes 1 and $6-$ molecular marker. (b) RT-PCR analysis with two $M L L$ sense primers located in $M L L$ exons 7 (lanes 2 and 3 ) and 8 (lanes 4 and 5) and two SEPT2 antisense primers located in SEPT2 exons 3 (lanes 3 and 5) and 4 (lanes 2 and 4). No amplification is observed with the $M L L$ exon 8 primer. Lanes 1 and 6 - molecular marker. Forward primers for $M L L$ exons 5, 6, 7 and 8 (GenBank Accession no. NM_005933) were previously described (Table 1; Yamamoto et al., 1994; Poirel et al., 1996). Reverse primers for SEPT2 exons 3, 4 and 9 were derived from the published sequence of SEPT2 mRNA with GenBank Accession no. NM_001008491 (Table 1). (c) Sequence analysis directly performed on the amplified RT-PCR product with the BigDye Terminator Cycle Sequencing Chemistry (Applied Biosystems, Foster City, USA) on a automated sequencer ABI Prism 310 Genetic Analyzer (Applied BioSystems, Foster City, USA), revealed an in-frame fusion between $M L L$ exon 7 and SEPT2 exon 3 (arrow).

Sequencing of the amplification products followed by a BLAST search confirmed that $M L L$ exon 7 was fused in-frame with nucleotide 431 of the SEPT2 transcript (GenBank Accession no. NM_001008491) (Figure 2c). No mutation or deletion was detected in the $M L L$ SEPT2 breakpoint region. This fusion is expected to give rise to a chimeric fusion protein where the $\mathrm{N}$-terminus of MLL is fused to almost the entire openreading frame of SEPT2, except for the first three amino acids. The putative MLL-SEPT2 fusion protein of 1764 amino acids contains 1406 amino acids from the $\mathrm{NH}_{2}$-terminal part of MLL and 358 amino acids from the COOH-terminal part of SEPT2.

For the identification of the genomic MLL-SEPT2 fusion, the $S E P T$-Int2AS-2 antisense primer was used in combination with the $M L L$-Ex7S and $M L L$-Int7S sense primers, giving rise to amplification products of 1240 and $1047 \mathrm{bp}$, respectively (Figure 3a). No amplification products were observed when primers $M L L$ Ex7S and $M L L$-Int7S were used with the antisense primer SEPT2-Int2AS-1 (Figure 3a). The results suggested that the genomic DNA breakpoint was located $3^{\prime}$ of $M L L$-Int7S and $5^{\prime}$ of SEPT2-Int2AS-1. Partial sequencing of the amplification products showed that the breakpoints were located $252 \mathrm{bp}$ downstream of
$M L L$ exon 7 and 447 bp downstream of SEPT2 exon 2 (Figure $3 b$ and $c$ ).

As our patient had been treated with epirubicin, a known topoisomerase II inhibitor, we searched for topoisomerase II consensus cleavages sites (Abeysinghe et al., 2003) near the vicinity of the breakpoint region. Using SeqTools (Rasmussen, 2004), we found two sequences with $94.4 \%$ homology with the topoisomerase II consensus cleavage site (one mismatch): one located in $M L L$ intron 7 (ATTAGCAGGTGGGTTTAG, nucleotide position $125-141$ bp downstream of $M L L$ exon 7) and the other in SEPT2 intron 2 (GTCACCAGGCTG GAGTGC, nucleotide position 184-201 bp downstream of SEPT2 exon 2). We also searched the breakpoint junction ( $15 \mathrm{bp}$ either side) for repetitive DNA sequence elements and motifs known to be associated with sitespecific recombination, cleavage and gene rearrangement (Abeysinghe et al., 2003; Chuzhanova et al., 2003), but we could not find any evidence of their presence. Finally, using RepeatMasker (Smit et al., 2004), we also searched both MLL intron 7 and SEPT2 intron 2 for low complexity DNA sequences and interspersed repeats. We found a $296 \mathrm{bp}$ Alu repeat in SEPT2 intron 2 located at nucleotides 148-309 downstream of SEPT2 exon 2. 


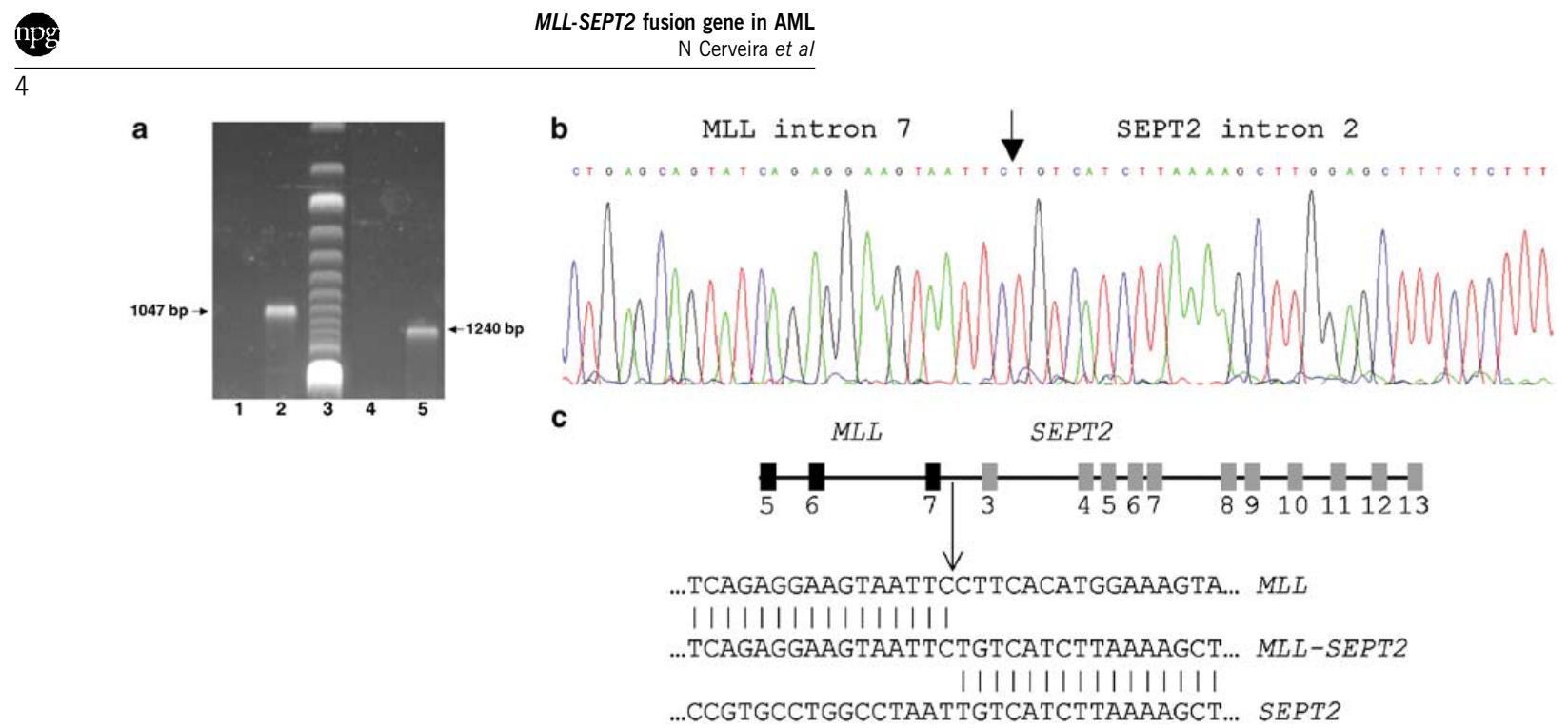

Figure 3 Detection and analysis of the $M L L-S E P T 2$ genomic breakpoint. (a) Amplification products of 1240 and 1047 bp were detected when the SEPT2-Int2AS-2 antisense primer was used in combination with $M L L$-Ex7S and $M L L$-Int7S sense primers, respectively (lanes 5 and 2). No amplification products were observed when primers $M L L$-Ex7S and $M L L$-Int7S were used with the antisense primer SEPT2-Int2AS-1 (lanes 1 and 4). These results suggest that the genomic DNA breakpoint was located $3^{\prime}$ of $M L L-$ Int7S and $5^{\prime}$ of SEPT2-Int2AS-2. Lane 3 - molecular marker. For primer localizations see Table 1. (b) Partial genomic sequence of $M L L-S E P T 2$ with the arrow showing the fusion between $M L L$ intron 7 and SEPT2 intron 2. (c) Schematic representation of the genomic breakpoint (arrow) and nucleotide sequence of the genomic breakpoints of the translocation $t(2 ; 11)$ and corresponding normal chromosomes 11 and 2 .

Identical translocations to the one we present have previously been reported in three patients with leukemia (DeLozier-Blanchet et al., 1985; Winick et al., 1993; Fischer et al., 1997), but no molecular genetic investigation of this chromosomal rearrangement had so far been described. The $M L L$ fusion partner we have identified, SEPT2, belongs to an evolutionarily conserved family of genes that encode a P loop-based GTP-binding domain flanked by a polybasic domain and (usually) a coiled-coil region (Hall and Russell, 2004; Russell and Hall, 2005). The SEPT2 protein possesses all the three domains and shares a very high homology with septins 1, 4 and 5 (Hall and Russell, 2004). Recently, it has been shown that there are at least 13 human septin genes (Russell and Hall, 2005). Four of them (SEPT5, SEPT6, SEPT9 and SEPT11) have already been cloned as $M L L$ fusion partners (Megonigal et al., 1998; Osaka et al., 1999; Taki et al., 1999a; Ono et al., 2002; Kojima et al., 2004), with the N-terminal moiety of $M L L$ fused to almost the entire open-reading frame of the partner septin gene (Russell and Hall, 2005). This is the fifth septin family gene fused with the $M L L$ gene described so far, making the septins the protein family most frequently involved in rearrangements with the $M L L$ gene. Septins constitute now nearly $10 \%$ of all fusion partners identified to date, suggesting that the involvement of this protein family in $M L L$-related leukemia is not a chance event. This hypothesis is supported by the fact that all the reported $M L L$-septin fusions are in frame and the breakpoints are found at the very 5 -end of known septin open-reading frames (Megonigal et al., 1998; Osaka et al., 1999; Taki et al., 1999a; Ono et al., 2002; Kojima et al., 2004).
We postulate that other septins may be involved in rearrangements with the $M L L$ gene. For instance, several reports (Berger et al., 1987; Marosi et al., 1992; Harrison et al., 1998; Satake et al., 1999) have shown the existence of a molecular rearrangement of the $M L L$ gene with a not yet identified fusion partner gene in 17q23, where the SEPT4 gene is located (Table 2). Furthermore, the existence of known $M L L$ partner genes in chromosomal bands where septin genes are mapped (Table 2 ) does not exclude the possibility that they also may be rearranged with $M L L$. In fact, several $M L L$ partner genes share the same chromosomal locations, like $A F 4$ and $S E P T 11$ (4q21) (Gu et al., 1992; Kojima et al., 2004), AF5q31 and GRAF (5q31) (Taki et al., 1999b; Borkhardt et al., 2000), FBP17 and AF9Q34 (9q34) (Fuchs et al., 2001; von Bergh et al., 2004), CBL and $L A R G$ (11q23) (Savage et al., 1991; Kourlas et al., 2000), AF15Q14 and MPFYVE (15q14) (Hayette et al., 2000; Chinwalla et al., 2003), LASP1 and AF17 (17q21) (Prasad et al., 1994; Strehl et al., 2003) and EEN and ENL (19p13.3) (Tkachuk et al., 1992; So et al., 1997). These data suggest that detailed molecular analysis is essential for the identification of other rearrangements involving the $M L L$ gene.

Although $M L L$ is a remarkably promiscuous leukemia-associated gene, current data suggest that these fusion partners fall into two distinct categories: those with a potent transactivation domain and nuclear localization and those that are located in the cytoplasm and possess potential oligomerization motifs (Nakamura et al., 2002; Daser and Rabbitts, 2005; Li et al., 2005). The septins do not possess an activation domain and there is no currently available evidence that they have 
MLL-SEPT2 fusion gene in AML

$\mathrm{N}$ Cerveira et al

Table 2 The human septin family of genes, their respective chromosomal location, and the genes at those locations known to be involved in rearrangements with the $M L L$ gene

\begin{tabular}{|c|c|c|c|c|}
\hline Name & Chromosomal location & $M L L-S E P T I N$ & $M L L$-other & References \\
\hline SEPT1 & $16 \mathrm{p} 11.1$ & NR & NR & - \\
\hline SEPT2 & $2 q 37.3$ & $M L L-S E P T 2$ & - & Present study \\
\hline SEPT3 & $22 q 13.2$ & NR & $M L L-E P 300$ & Ida et al. (1997) \\
\hline SEPT4 & $17 \mathrm{q} 23$ & $M L L-S E P T 4 ?$ & NR & $\begin{array}{l}\text { Berger et al. (1987); Marosi et al. (1992); } \\
\text { Harrison et al. (1998); Satake et al. (1999) }\end{array}$ \\
\hline SEPT5 & $22 \mathrm{q} 11.2$ & $M L L-S E P T 5$ & NR & Megonigal et al. (1998) \\
\hline SEPT6 & Xq24 & $M L L-S E P T 6$ & NR & Ono et al. (2002) \\
\hline SEPT7 & $7 \mathrm{p} 14.2$ & NR & NR & - \\
\hline SEPT8 & $5 q 31$ & NR & $M L L-A F 5 q 31, M L L-G R A F$ & Taki et al. (1999b); Borkhardt et al. (2000) \\
\hline SEPT9 & $17 \mathrm{q} 25.3$ & $M L L-S E P T 9$ & NR & Taki et al. (1999a); Osaka et al. (1999) \\
\hline SEPT10 & $2 q 13$ & NR & NR & - \\
\hline SEPT11 & $4 q 21$ & $M L L-S E P T 11$ & $M L L-A F 4$ & Gu et al. (1992); Kojima et al. (2004) \\
\hline SEPT12 & $16 \mathrm{p} 13.3$ & NR & $M L L-C R E B B P$ & Sobulo et al. (1997); Taki et al. (1997) \\
\hline SEPT13 & 7 p13 & NR & NR & - \\
\hline
\end{tabular}

Abbreviation: NR - not reported

other than a cytoplasmatic localization, but they are believed to oligomerize via their coiled-coil domain. Oligomerization of MLL-fused septins could then facilitate deregulated activity of MLL with recruitment of transcriptional activators. One exception is SEPT9, which lacks the coiled-coil domain present in other $M L L$-fused septins (Russell and Hall, 2005) and presumably has an alternative domain involved in the formation of oligomers. A recent report showed that oligomerization of MLL-SEPT6 is essential to immortalize hematopoietic progenitors in vitro and that the GTP-binding domain may have a role in the formation of dimers (Ono et al., 2005).

Although the presently available data suggest that the involvement of septins in $M L L$-related leukemia is only related to their capacity to oligomerize, the possibility that they have oncogenic activity of their own cannot be completely ruled out. Septins have roles in cytokinesis, vesicle traffic, polarity determination, microtubule and actin dynamics, and can form membrane diffusion barriers (Russell and Hall, 2005). For instance, SEPT2, the first human septin to be systematically studied, was shown to be required for cytokinesis and to bind actin and associate with focal adhesions (Kinoshita et al., 1997; Surka et al., 2002). Additionally, recent data support the idea that mammalian septins can form a novel scaffold at the midplane of the mitotic spindle that coordinates several key steps of mitosis, suggesting that SEPT2 can have a role in chromosome congression and segregation, and that altered expression of SEPT2 might lead to disordered chromosomal dynamics and underlie the development of aneuploidy (Spiliotis et al., 2005). However, the question of whether and how the normal function of SEPT2 is altered by its fusion to MLL remains to be elucidated.

\section{References}

Abeysinghe SS, Chuzhanova N, Krawczak M, Ball EV, Cooper DN. (2003). Hum Mutat 22: 229-244.
Topoisomerase II inhibitor-related AML can be distinguished from other therapy-related leukemia by its genetic signature: balanced translocations involving the MLL gene (Pui and Relling, 2000). The identification of two sequences with $94.4 \%$ homology with the topoisomerase II consensus cleavage site in our patient, one located in $M L L$ intron 7 and the other in SEPT2 intron 2 , provides support to a link between topoisomerase II inhibitor therapy and the origin of the MLL-SEPT2 fusion gene in this particular case. Nevertheless, one must be cautious in interpreting this finding, as topoisomerase II consensus cleavages sites are either short, highly redundant or both, so their chance occurrence at breakpoint junctions is unlikely to be infrequent. Therefore, their presence at a given translocation breakpoint should not be automatically taken to imply that they are directly involved in the mechanisms of rearrangement (Abeysinghe et al., 2003). In addition, the presence of a 296 bp Alu repeat in SEPT2 intron 2 can, in theory, be related with the $M L L-S E P T 2$ formation, as Alu sequences found in the vicinity of breakpoint regions can mediate the corresponding rearrangement by nonhomologous recombination (Rudiger et al., 1995).

In summary, we have identified SEPT2 as the $M L L$ fusion partner in therapy-related AML with a $\mathrm{t}(2 ; 11)(\mathrm{q} 37 ; \mathrm{q} 23)$. This is the fifth septin that has been found fused with $M L L$ in acute leukemia, but the precise role played by this family of genes in this disease remains incompletely known. A more detailed characterization of the functions of septins may contribute to a better understanding of MLL-mediated leukemogenesis.

\section{Acknowledgements}

This research was supported by Liga Portuguesa Contra o Cancro - Núcleo Regional do Norte.

Berger R, Flandrin G, Bernheim A, Le Coniat M, Vecchione D, Pacot A et al. (1987). Cancer Genet Cytogenet 29: 9-21. 
Borkhardt A, Bojesen S, Haas OA, Fuchs U, Bartelheimer D Loncarevic IF et al. (2000). Proc Natl Acad Sci USA 97: 9168-9173.

Chinwalla V, Chien A, Odero M, Neilly MB, Zeleznik-Le NJ, Rowley JD. (2003). Oncogene 22: 1400-1410.

Chuzhanova N, Abeysinghe SS, Krawczak M, Cooper DN. (2003). Hum Mutat 22: 245-251.

Daser A, Rabbitts TH. (2005). Semin Cancer Biol 15: 175-188.

DeLozier-Blanchet CD, Cabrol C, Werner-Favre C, Beris P, Engel E. (1985). Cancer Genet Cytogenet 16: 95-102.

Fischer K, Frohling S, Scherer SW, McAllister Brown J, Scholl C, Stilgenbauer S et al. (1997). Blood 89: 2036-2041.

Fuchs U, Rehkamp G, Haas OA, Slany R, Konig M, Bojesen S et al. (2001). Proc Natl Acad Sci USA 98: 8756-8761.

Grier DG, Thompson A, Kwasniewska A, McGonigle GJ, Halliday HL, Lappin TR. (2005). J Pathol 205: 154-171.

Gu Y, Nakamura T, Alder H, Prasad R, Canaani O, Cimino G et al. (1992). Cell 71: 701-708.

Hall PA, Russell SE. (2004). J Pathol 204: 489-505.

Harrison CJ, Cuneo A, Clark R, Johansson B, LafagePochitaloff M, Mugneret F et al. (1998). Leukemia 12 811-822.

Hayette S, Tigaud I, Vanier A, Martel S, Corbo L, Charrin C et al. (2000). Oncogene 19: 4446-4450.

Huret JL. (2005). Atlas of Genetics and Cytogenetics in Oncology and Haematology http://www.infobiogen.fr/ services/chromcancer/Genes/MLL.html.

Ida K, Kitabayashi I, Taki T, Taniwaki M, Noro K, Yamamoto M et al. (1997). Blood 90: 4699-4704.

ISCN (1995). An International System for Human Cytogenetic Nomenclature. Karger: Basel.

Kinoshita M, Kumar S, Mizoguchi A, Ide C, Kinoshita A, Haraguchi T et al. (1997). Genes Dev 11: 1535-1547.

Kojima K, Sakai I, Hasegawa A, Niiya H, Azuma T, Matsuo Y et al. (2004). Leukemia 18: 998-1005.

Kourlas PJ, Strout MP, Becknell B, Veronese ML, Croce CM, Theil KS et al. (2000). Proc Natl Acad Sci USA 97: 2145-2150.

Li ZY, Liu DP, Liang CC. (2005). Leukemia 19: 183-190.

Marosi C, Koller U, Koller-Weber E, Schwarzinger I, Schneider B, Jager U et al. (1992). Cancer Genet Cytogenet 61: $14-25$.

Megonigal MD, Rappaport EF, Jones DH, Williams TM Lovett BD, Kelly KM et al. (1998). Proc Natl Acad Sci USA 95: 6413-6418.

Milne TA, Briggs SD, Brock HW, Martin ME, Gibbs D, Allis CD et al. (2002). Mol Cell 10: 1107-1117.

Nakamura T, Mori T, Tada S, Krajewski W, Rozovskaia T, Wassell R et al. (2002). Mol Cell 10: 1119-1128.

Ono R, Nakajima H, Ozaki K, Kumagai H, Kawashima T, Taki T et al. (2005). J Clin Invest 115: 919-929.

Ono R, Taki T, Taketani T, Kawaguchi H, Taniwaki M, Okamura T et al. (2002). Cancer Res 62: 333-337.

Osaka M, Rowley JD, Zeleznik-Le NJ. (1999). Proc Natl Acad Sci USA 96: 6428-6433.

Poirel H, Rack K, Delabesse E, Radford-Weiss I, Troussard X, Debert C et al. (1996). Blood 87: 2496-2505.

Popovic R, Zeleznik-Le NJ. (2005). J Cell Biochem 95 234-242.

Prasad R, Leshkowitz D, Gu Y, Alder H, Nakamura T, Saito H et al. (1994). Proc Natl Acad Sci USA 91: 8107-8111.

Pui CH, Relling MV. (2000). Br J Haematol 109: 13-23.

Rasmussen SW. (2004). SEQ Tools Version 8.2 - Build 101 http://www.seqtools.dk.

Rudiger NS, Gregersen N, Kielland-Brandt MC. (1995). Nucleic Acids Res 23: 256-260.

Russell SE, Hall PA. (2005). Br J Cancer 93: 499-503.

Satake N, Maseki N, Nishiyama M, Kobayashi H, Sakurai M, Inaba H et al. (1999). Leukemia 13: 1013-1017.

Savage PD, Shapiro M, Langdon WY, Geurts van Kessel AD, Seuanez HN, Akao Y et al. (1991). Cytogenet Cell Genet 56: $112-115$

Slany RK. (2005). Hematol Oncol 23: 1-9.

Smit AFA, Hubley R, Green P. (2004). RepeatMasker Open3.0 http://www.repeatmasker.org.

So CW, Caldas C, Liu MM, Chen SJ, Huang QH, Gu LJ et al. (1997). Proc Natl Acad Sci USA 94: 2563-2568.

Sobulo OM, Borrow J, Tomek R, Reshmi S, Harden A, Schlegelberger B et al. (1997). Proc Natl Acad Sci USA 94 8732-8737.

Spiliotis ET, Kinoshita M, Nelson WJ. (2005). Science 307: 1781-1785.

Strehl S, Borkhardt A, Slany R, Fuchs UE, Konig M, Haas OA. (2003). Oncogene 22: 157-160.

Surka MC, Tsang CW, Trimble WS. (2002). Mol Biol Cell 13 353235-353245.

Taki T, Kano H, Taniwaki M, Sako M, Yanagisawa M, Hayashi Y. (1999b). Proc Natl Acad Sci USA 96 $14535-14540$

Taki T, Ohnishi H, Shinohara K, Sako M, Bessho F, Yanagisawa M et al. (1999a). Cancer Res 59: 4261-4265.

Taki T, Sako M, Tsuchida M, Hayashi Y. (1997). Blood 89 3945-3950.

Tkachuk DC, Kohler S, Cleary ML. (1992). Cell 71: 691-700.

von Bergh AR, Wijers PM, Groot AJ, van Zelderen-Bhola S, Falkenburg JH, Kluin PM et al. (2004). Genes Chromosomes Cancer 39: 324-334.

Winick NJ, McKenna RW, Shuster JJ, Schneider NR, Borowitz MJ, Bowman WP et al. (1993). J Clin Oncol 11: 209-217.

Yamamoto K, Seto M, Iida S, Komatsu H, Kamada N, Kojima S et al. (1994). Blood 83: 2912-2921. 


\title{
PAPER \#2
}

Nuno Cerveira, Joana Santos, Manuela Pinheiro, Simone Snijder, Hans van der Lelie, Clemens $H$ Mellink, Manuel $R$. Teixeira

\section{A NOVEL MLL-SEPT2 FUSION VARIANT IN THERAPY-RELATED MYELODYSPLASTIC SYNDROME}

\author{
Cancer Genet Cytogenet, 185: 62-64, 2008
}


MATERIAL AND METHODS, RESULTS AND DISCUSSION 


\section{A novel $M L L-S E P T 2$ fusion variant in therapy-related myelodysplastic syndrome}

Recurring chromosomal abnormalities are common in hematopoietic malignancies and typically result in the formation of oncogenic fusion genes. For instance, more than 50 genes have already been cloned as $M L L$ fusion partners, and the resulting chimeric proteins are associated with acute lymphoblastic leukemia (ALL), acute myeloid leukemia (AML), as well as with therapy-related acute leukemia or myelodysplastic syndrome [1].
Our group has established the $M L L-S E P T 2$ gene fusion as the molecular abnormality subjacent to the $t(2 ; 11)(\mathrm{q} 37 ; \mathrm{q} 23)$ in a case of therapy-related acute myeloid leukemia (t-AML) of the M4 FAB subtype [2]. The molecular characterization of the fusion transcript showed a fusion of $M L L$ exon 7 with SEPT2 exon 3 (type I fusion transcript) [2]. van Binsbergen et al. [3] subsequently identified a second $M L L-S E P T 2 \mathrm{fu}-$ sion variant involving $M L L$ exon 6 with SEPT2 exon 6 (type

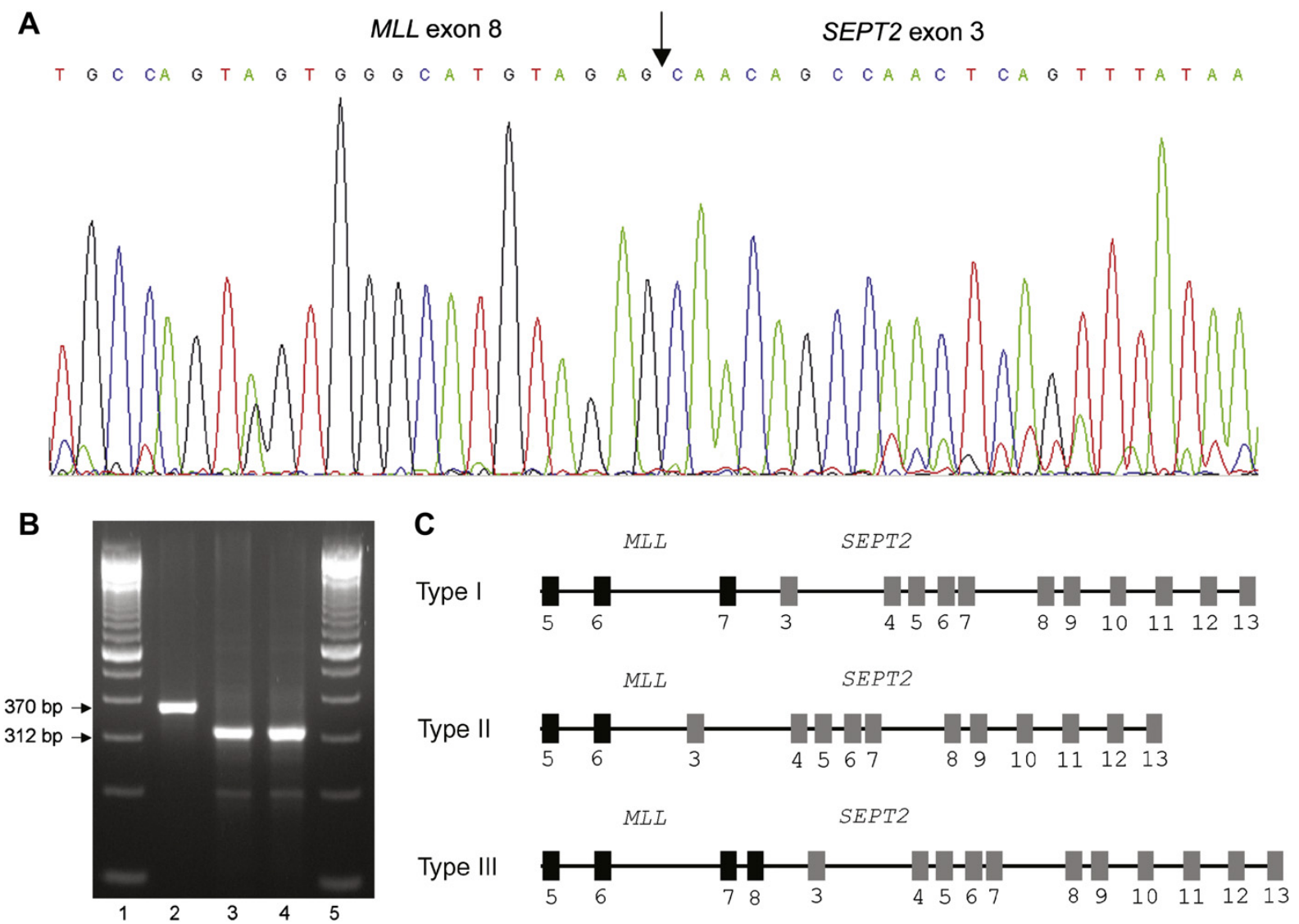

Figure 1. Molecular characterization of the MLL-SEPT2 fusion. (A) Lanes 3 and 4: RT-PCR analysis showing the variant $M L L-S E P T 2$ transcript. Lane 2: RNA integrity check (B2 $M$ gene) showing clear amplification. Lanes 1 and 5: 100-bp molecular marker. (B) Sequence analysis performed on the amplified RT-PCR product revealed an in-frame fusion between $M L L$ exon 8 and SEPT2 exon 3 (arrow). (C) Structure of the three MLL-SEPT2 variant forms identified to date: type I was identified by Cerveira et al. [2], type II by van Binsbergen et al. [3], and type III is reported here.

0165-4608/08/\$ - see front matter (C) 2008 Elsevier Inc. All rights reserved. doi:10.1016/j.cancergencyto.2008.05.002 
II fusion transcript) in a patient with t-AML of the M2 FAB subtype [3].

In a recent issue of this journal, Snijder et al. [4] reported the characterization by conventional cytogenetics and fluorescent in situ hybridization (FISH) of another case of $\mathrm{t}(2 ; 11)(\mathrm{q} 37 ; \mathrm{q} 23)$ in a patient with therapy-related myelodysplastic syndrome (t-MDS) after treatment for acute promyelocytic leukemia. The detection by FISH of an $M L L$ rearrangement during follow-up, associated with the identification of $\mathrm{t}(2 ; 11)(\mathrm{q} 37 ; \mathrm{q} 23)$, suggested the presence of an MLL-SEPT2 fusion gene. As part of an international collaboration to study the relevance of septins in leukemogenesis, we have analyzed a t-MDS sample of this patient by reverese-transcription polymerase chain reaction (RTPCR) with previously published primers for $M L L$ exon 8 and SEPT2 exon 3 [2]. The detection of a 312-base pair (bp) polymerase chain reaction fragment suggested a novel $M L L-S E P T 2$ rearrangement resulting from fusion of $M L L$ exon 8 with SEPT2 exon 3 (Fig. 1A), which was confirmed by sequencing the amplification product (Fig. 1B). This novel $M L L-S E P T 2$ fusion variant, which we call type III after the two previously identified fusion types (Fig. 1C), is expected to give rise to a chimeric fusion protein where the $\mathrm{N}$ terminus of MLL is fused to almost the entire open reading frame of SEPT2, except for the first three amino acids $[2,3]$. Although patients with different subtypes of $M L L$ fusion transcripts are not believed to differ significantly regarding biological and clinical parameters, their identification and detailed characterization is essential for accurate molecular subtyping at diagnosis.

All three cases with the MLL-SEPT2 gene fusion are adults (age range between 54 and 68 years old) with t-MDS/t-AML after treatment of previous neoplasias with topoisomerase II inhibitor chemotherapy [2-4]. Interestingly, all 13 patients identified so far with a gene fusion between $M L L$ and another septin family gene (SEPT6) are children (age range between 0 and 29 months) with AML (the French-American-British typed ones included one M1, five M2, four M4, and one M5) [5]. Despite the different age distribution (MLL-SEPT2 case are adults and $M L L-S E P T 6$ cases are children), it is tempting to speculate that the cause of the MLL-SEPT gene fusions in both groups might be exposition to topoisomerase II inhibitors. In agreement with this hypothesis are some studies that suggest a causal relationship between infant leukemia induced in utero and maternal exposure to dietary compounds that can act as topoisomerase II poisons [6-8] and the observation that all $M L L-S E P T 2$ cases are the result of treatment with chemotherapy containing topoisomerase II inhibitors [2-4]. Further studies with higher number of cases will be necessary to confirm or refute this relationship.

\section{Acknowledgments}

The authors thank Ingrid Lommerse from Sanquin Diagnostics Services for providing cDNA material. This research was supported by grants from the "Associação Portuguesa Contra a Leucemia" (2006-30.2.AP/MJ) and the "Comissão de Fomento da Investigação em Cuidados de Saúde" (P.I. 26/2007).

Nuno Cerveira

Joana Santos

Manuela Pinheiro

Department of Genetics

Portuguese Oncology Institute

Rua Dr. António Bernardino de Almeida 4200-072 Porto, Portugal

Simone Snijder

Department of Clinical Genetics Academic Medical Center Meibergdreef, 15

1105 Amsterdam, The Netherlands

Hans van der Lelie Department of Internal Medicine Division of Hematology Meibergdreef, 15, Academic Medical Center 1105 Amsterdam, The Netherlands

Clemens H.M. Mellink Department of Clinical Genetics Meibergdreef, 15, Academic Medical Center Amsterdam, The Netherlands

Manuel R. Teixeira Department of Genetics Portuguese Oncology Institute Rua Dr. António Bernardino de Almeida 4200-072 Porto, Portugal

Abel Salazar Biomedical Sciences Institute (ICBAS) Porto, Portugal

\section{References}

[1] Meyer C, Schneider B, Jakob S, Strehl S, Attarbaschi A, Schnittger S, Schoch C, Jansen MW, van Dongen JJ, den Boer ML, Pieters R, Ennas MG, Angelucci E, Koehl U, Greil J, Griesinger F, Zur Stadt U, Eckert C, Szczepański T, Niggli FK, Schäfer BW, Kempski H, Brady HJ, Zuna J, Trka J, Nigro LL, Biondi A, Delabesse E, Macintyre E, Stanulla M, Schrappe M, Haas OA Burmeister T, Dingermann T, Klingebiel T, Marschalek R. The MLL recombinome of acute leukemias. Leukemia 2006;20:777-84.

[2] Cerveira N, Correia C, Bizarro S, Pinto C, Lisboa S, Mariz JM, Marques M, Teixeira MR. SEPT2 is a new fusion partner of MLL in acute myeloid leukemia with $\mathrm{t}(2 ; 11)(\mathrm{q} 37 ; \mathrm{q} 23)$. Oncogene 2006;25:6147-52.

[3] van Binsbergen E, de Weerdt O, Buijs A. A new subtype of MLLSEPT2 fusion transcript in therapy-related acute myeloid leukemia with $\mathrm{t}(2 ; 11)(\mathrm{q} 37 ; \mathrm{q} 23)$ : a case report and literature review. Cancer Genet Cytogenet 2007;176:72-5

[4] Snijder S, Mellink CH, van der Lelie H. Translocation $(2 ; 11)(\mathrm{q} 37$; q23) in therapy-related myelodysplastic syndrome after treatment for acute promyelocytic leukemia. Cancer Genet Cytogenet 2008; 180:149-52. 
MATERIAL AND METHODS, RESULTS AND DISCUSSION

[5] Cerveira N, Micci F, Santos J, Pinheiro M, Correia C, Lisboa S, Bizarro S, Norton L, Glomstein A, Åsberg AE, Heim S, Teixeira MR. Molecular characterisation of the MLL-SEPT6 fusion gene in acute myeloid leukaemia: identification of novel fusion transcripts and cloning of genomic breakpoint junctions. Haematologica; Epub May 19, 2008, doi 10.3324/haematol.12594.

[6] Strick R, Strissel PL, Borgers S, Smith SL, Rowley JD. Dietary bioflavonoids induce cleavage in the MLL gene and may contribute to infant leukemia. Proc Natl Acad Sci USA 2000;97:4790-5.
[7] Alexander FE, Patheal SL, Biondi A, Brandalise S, Cabrera ME, Chan LC, Chen Z, Cimino G, Cordoba JC, Gu LJ, Hussein H, Ishii E, Kamel AM, Labra S, Magalhães IQ, Mizutani S, Petridou E, de Oliveira MP, Yuen P, Wiemels JL, Greaves MF. Transplacental chemical exposure and risk of infant leukemia with MLL gene fusion. Cancer Res 2001;61:2542-6.

[8] McDonald TA, Holland NT, Skibola C, Duramad P, Smith MT. Hypothesis: phenol and hydroquinone derived mainly from diet and gastrointestinal flora activity are causal factors in leukemia. Leukemia 2001;15:10-20. 
MATERIAL AND METHODS, RESULTS AND DISCUSSION 


\section{PAPER \#3}

Nuno Cerveira, Francesca Micci, Joana Santos, Manuela Pinheiro, Cecília Correia, Susana Lisboa, Susana Bizarro, Lucília Norton, Anders Glomstein, Ann E. Åsberg, Sverre Heim, Manuel R. Teixeira

\section{MOLECULAR CHARACTERISATION OF THE MLL-SEPT6 FUSION GENE IN ACUTE MYELOID LEUKAEMIA: IDENTIFICATION OF NOVEL FUSION TRANSCRIPTS AND CLONING OF GENOMIC BREAKPOINT JUNCTIONS}


MATERIAL AND METHODS, RESULTS AND DISCUSSION 


\title{
Molecular characterization of the MLL-SEPT6 fusion gene in acute myeloid leukemia: identification of novel fusion transcripts and cloning of genomic breakpoint junctions
}

\author{
Nuno Cerveira, ${ }^{1}$ Francesca Micci, ${ }^{2}$ Joana Santos, ${ }^{1}$ Manuela Pinheiro, ${ }^{1}$ Cecília Correia,${ }^{1}$ \\ Susana Lisboa, ${ }^{1}$ Susana Bizarro, ${ }^{1}$ Lucília Norton, ${ }^{3}$ Anders Glomstein, ${ }^{4}$ Ann E. Åsberg, ${ }^{5}$ \\ Sverre Heim, ${ }^{2,6}$ and Manuel R. Teixeira ${ }^{1,7}$ \\ ${ }^{1}$ Department of Genetics, Portuguese Oncology Institute, Porto, Portugal; ${ }^{2}$ Section for Cancer Cytogenetics, \\ Department of Medical Genetics, Radiumhospitalet-Rikshospitalet Medical Center, Oslo, Norway; ${ }^{3}$ Department of \\ Pediatrics, Portuguese Oncology Institute, Porto, Portugal; ${ }^{4}$ Department of Pediatrics, Radiumhospitalet- \\ Rikshospitalet Medical Center, Oslo, Norway; ${ }^{5}$ Department of Pediatrics, St Olav University Hospital, Trondheim, \\ Norway; ${ }^{6}$ Faculty Division, The Norwegian Radium Hospital, Medical Faculty, University of Oslo, Norway and \\ ${ }^{7}$ Biomedical Sciences Institute (ICBAS), University of Porto, Porto, Portugal
}

\begin{tabular}{|c|c|}
\hline \multicolumn{2}{|c|}{ ABSTRACT } \\
\hline \multicolumn{2}{|c|}{$\begin{array}{l}\text { One of the MLL fusion partners in leukemia is the SEPT6 gene, which belongs to the evolutionarily conserved family of genes of septins. } \\
\text { In this work we aimed to characterize at both the RNA and DNA levels three acute myeloid leukemias with cytogenetic evidence of a } \\
\text { rearrangement between } 11 \mathrm{q} 23 \text { and Xq24. Molecular analysis led to the identification of several MLL-SEPT6 fusion transcripts in all cases, } \\
\text { including a novel MLL-SEPT6 rearrangement (MLL exon } 6 \text { fused with SEPT6 exon 2). Genomic DNA breakpoints were found inside or near } \\
\text { Alu or LINE repeats in the MLL breakpoint cluster region, whereas the breakpoint junctions in the SEPT6 intron } 1 \text { mapped to the vicinity } \\
\text { of GC-rich low-complexity repeats, Alu repeats, and a topoisomerase II consensus cleavage site. These data suggest that a non-homolo- } \\
\text { gous end-joining repair mechanism may be involved in the generation of MLL-SEPT6 rearrangements in acute myeloid leukemia. }\end{array}$} \\
\hline \multicolumn{2}{|c|}{ Key words: MLL-SEPT6, fusion oncogene, fusion transcript, genomic breakpoint, acute myeloid leukemia. } \\
\hline \multicolumn{2}{|c|}{$\begin{array}{l}\text { Citation: Cerveira N, Micci F, Santos J, Pinheiro M, Correia C, Lisboa S, Bizarro S, Norton L, Glomstein A, Åsberg AE, Heim S, and Teixeira } \\
\text { MR. Molecular characterization of the MLL-SEPT6 fusion gene in acute myeloid leukemia: identification of novel fusion transcripts and } \\
\text { cloning of genomic breakpoint junctions. Haematologica 2008; 93:1076-1080. doi: 10.3324/haematol.12594 }\end{array}$} \\
\hline (C)2008 Ferrata Storti Foundation. This is an open access paper. & \\
\hline $\begin{array}{l}\text { ntroduction } \\
\text { Abnormalities of } 11 \mathrm{q} 23 \text {, resulting in fusion of the mixed } \\
\text { ineage leukemia (MLL) gene with numerous translocation } \\
\text { artners, are found in primary acute lymphoblastic leukemia } \\
\text { ALL) and acute myeloid leukemia (AML), as well as in sec- } \\
\text { ndary, topoisomerase II inhibitor-related leukemia. }{ }^{1} \text { The } \\
\text { MLL gene codes for a multi-domain protein that is a major } \\
\text { egulator of class I homeobox (HOX) gene expression. }{ }^{2} H O X \\
\text { enes play a key role in the regulation of hematopoietic } \\
\text { levelopment and altered patterns of MLL activity might } \\
\text { ause abnormal HOX gene expression in hematopoietic stem } \\
\text { ells, resulting in blockage of hematopoietic maturation and, } \\
\text { ventually, leukemia. } \\
\text { To date, more than } 50 M L L \text { fusion partners have been } \\
\text { loned. }{ }^{4} \text { Five of these, SEPT2, SEPT5, SEPT6, SEPT9, and }\end{array}$ & $\begin{array}{l}\text { SEPT11, code for septins } \text { s., }^{4,5} \text { and belong to an evolutionarily } \\
\text { conserved family of genes with } 13 \text { members identified so } \\
\text { far. }{ }^{6} \text { As a consequence, the septins are the protein family } \\
\text { most frequently involved in rearrangements with } M L L \text {, sug- } \\
\text { gesting that their involvement in MLL-related leukemia is } \\
\text { anything but a chance event., Septins are conserved GTP- } \\
\text { binding proteins that assemble into homo- and hetero- } \\
\text { oligomers and filaments with key roles in cell division } \\
\text { cytoskeletal dynamics and secretion. } \\
\text { To our knowledge, the fusion between } M L L \text { and SEPT6 } \\
\text { has so far only been described in } 10 \text { AML patients.-13 } \\
\text { However, the genomic breakpoint junction was only charac- } \\
\text { terized in } 2 \text { patients. }{ }^{9,10} \text { We present a detailed RNA and DNA } \\
\text { analysis in } 3 \text { new AML patients with the MLL-SEPT6 } \\
\text { rearrangement, one of them showing a novel in-frame fusion } \\
\text { transcript. }\end{array}$ \\
\hline
\end{tabular}

Funding: this research was supported by grants from the "Associação Portuguesa Contra a Leucemia" (2006-30.2.AP/MJ) and the "Comissão de Fomento da Investigação em Cuidados de Saúde" (P.I. 26/2007).

Manuscript received December 6, 2007. Revised version arrived on February 11, 2008. Manuscript accepted Feburary 13, 2008.

Correspondence: Manuel R. Teixeira, Department of Genetics, Portuguese Oncology Institute, Rua Dr. António Bernardino de Almeida, 4200-072 Porto,

Portugal. E-mail: mteixein@ipoporto.min-saude.pt

The online version of this article contains a supplementary appendix. 


\section{Design and Methods}

The study comprised three cases of childhood AML in which Xq24 and 11q23 rearrangements were detected by karyotyping and/or molecular cytogenetic analyses of the leukemic cells. Molecular studies involved RT-PCR, LD-PCR, HN-PCR, sequencing, and bioinformatic analyses. For detailed information on patients, methods and results see Online Supplementary Appendix.

\section{Results and Discussion}

\section{Karyotyping and molecular cytogenetics}

The 3 AML patients showed cytogenetic evidence of a rearrangement involving the long arm of chromosome 11 (11q23), the first with additional material of unknown origin in 11q23 and Xp11 (patient 1), the second as a translocation between $11 \mathrm{q} 23$ and $\mathrm{Xq} 24$, and the third as an insertion of 11q13q23 into Xq24 (Table 1, Figure 1). FISH analysis on leukemic metaphases was performed, demonstrating in all cases a break in $M L L$ (Figure 1) and the presence of $M L L$ sequences in Xq (cytogenetically cryptic in case 1). The known localization of SEPT6 in Xq24 prompted further analysis with BACs mapped to this band in patients 2 and 3 . In patient 2, the breakpoint was mapped to clone CTD2334F19, suggesting a breakpoint in or near the $5^{\prime}$ region of the SEPT6 gene. In patient 3 , the breakpoint was mapped to the overlapping region of the two BAC clones RP11-379J1 and CTD-2334F19, which suggested that the break occurred in the 5' region of the SEPT6 gene. In patient $1, \mathrm{BAC}$ analysis could not be performed due to lack of material. Rearrangements recombining 11q23 and Xq24 resulting in MLL-SEPT6 fusions are usually complex as a result of the opposite orientation of MLL and SEPT6 on the respective chromosome arms. At least four different types of chromosomal rearrangements have been described that can generate the MLL-SEPT6 in-frame fusion. ${ }^{7-10}$ The combined chromosome banding and molecular cytogenetic investigations of our 3 patients confirm that complex, sometimes cryptic, chromosome rearrangements are common in AML patients with MLL-SEPT6 rearrangements (Table 1).

\section{Characterization of MLL-SEPT6 fusion transcripts}

RT-PCR followed by sequencing analysis led to the identification of MLL-SEPT6 fusion transcripts in all 3 cases. In patient 1 , two major PCR fragments of $719 \mathrm{bp}$ and 605 bp were detected (Online Supplementary Figure 1A). Sequencing analysis revealed a fusion of $M L L$ exon 7 and $M L L$ exon 8 with SEPT6 exon 2. In addition, a minor band of $541 \mathrm{bp}$ detected in this patient (Online Supplementary Figure S1A) was shown by sequencing analysis to correspond to an out-of-frame fusion between MLL exon 7 and SEPT6 exon 2 with splicing of $74 \mathrm{bp}$ corresponding to $M L L$ exon 6 . RT-PCR analysis of patient 2 revealed one major band of $473 \mathrm{bp}$ and a minor band of $399 \mathrm{bp}$ (Online Supplementary Figure $S 1 B)$. Sequencing analysis revealed the presence of two

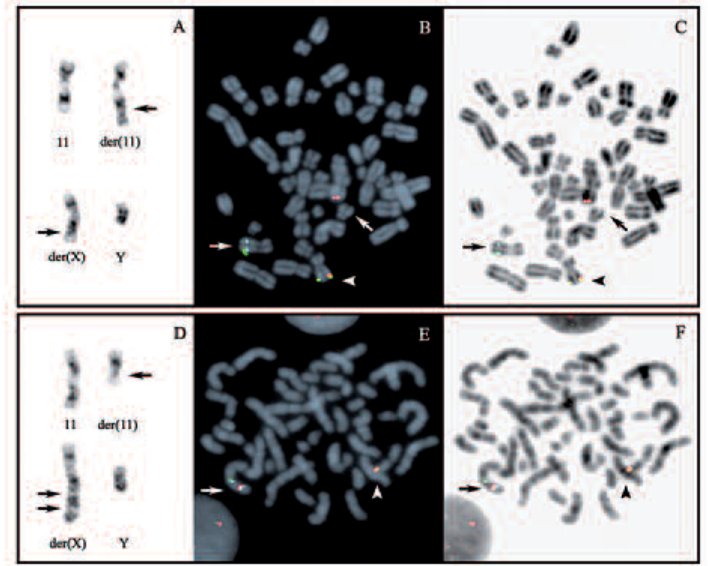

Figure 1. G-banding and FISH analyses of the leukemic cells of Figure 1. G-banding and FISH analyses of the leukemic cells of
patients 2 and 3. (A) Partial karyotype of case 2, with arrows indipatients 2 and 3. (A) Partial karyotype of case 2, with arrows indi-
cating breakpoints of rearranged chromosomes. (B) FISH and (C) cating breakpoints of rearranged chromosomes. (B) FISH and (C)
inverted DAPI images of metaphase plate from case 2. The hybridization was performed using a locus-specific, break-apart probe for MLL (green and red signals) and the BAC clone CTD2334 F19 (blue signal). The blue signal has moved to the derivative chromosome 11, indicating that the breakpoint is in the 5' of the SEPT6 gene. Arrows indicate derivative chromosomes, arrow hea heads are pointing to the normal chromosome 11. (D) Partial karyotype of case 3. (E) FISH and (F) inverted DAPI images of a metaphase plate from case 3 . Hybridization was performed using the MLL probe and the clone CTD-2334F19. The BAC clone (blue colour) splits giving two signals on the rearranged $X$ chromosome, indicating that the breakpoint is inside that clone.

novel MLL-SEPT6 chimeric transcripts: an in-frame fusion between MLL exon 6 and SEPT6 exon 2 and an out-of-frame fusion of $M L L$ exon 5 to SEPT6 exon 2 (Online Supplementary Figure S1D). The novel MLLSEPT6 in-frame fusion variant is expected to give rise to a chimeric fusion protein, where the $\mathrm{N}$ terminus of $M L L$ fused to almost the entire open reading frame of SEPT6, except for the first nine amino acids.

In patient 3, RT-PCR analysis showed the presence of two PCR fragments of $605 \mathrm{bp}$ and $541 \mathrm{bp}$ (Online Supplementary Figure S1C). Sequencing analysis demonstrated fusions between $M L L$ exon 7 and SEPT6 exon 2, with the smaller fragment showing, as in patient 1, an out-of-frame splicing of $M L L$ exon 6 . The 10 cases of MLL-SEPT6 rearrangement described so far showed fusions between SEPT6 exon 2 and $M L L$ exon 7 (3 cases), MLL exon 8 (3 cases), both MLL exons 7 and 8 (3 cases), or $M L L$ exon 9 (one case) ${ }^{8-13}$ The novel MLL-SEPT6 chimeric transcript we here describe between $M L L$ exon 6 and SEPT6 exon 2 may be called type IV, after the three fusion types previously identified (Table 1).

SEPT6 belongs to an evolutionarily conserved family of genes that encode a P loop-based GTP-binding domain flanked by a polybasic domain and, in most cases, a coiled-coil-region. ${ }^{6}$ The SEPT6 protein possesses all the three domains and, as previously reported in cases of gene fusion involving $M L L$ and other septins (MLL-SEPT2, MLL-SEPT5, MLL-SEPT9, and MLL- 
SEPT11), almost the entire open reading frame of SEPT6, containing all the three septin function-defining domains, is fused with the N-terminal moiety of $M L L$. A relevant role of septins in $M L L$-related leukemia, besides activation of the MLL protein by dimerization, is therefore a possibility that should not be ruled out. ${ }^{5,6}$ Additional support for this hypothesis comes from the observation that all 13 patients reported so far with $M L L-S E P T 6$ rearrangement were children (age range; 0 29 months) with AML (the FAB-typed included one M1, five M2, four M4 and one M5; Table 1). Since the majority $(65 \%)$ of pediatric patients with $M L L$ rearrangements have ALL, ${ }^{4}$ we hypothesize that the SEPT6 domains of the MLL-SEPT6 chimeric protein contribute to myeloblastic leukemogenesis in children. In fact, the MLL fusion with the other septins (SEPT2, SEPT5, SEPT9, and SEPT11) is also preferentially associated with myeoloblastic rather than lymphoblastic leukemogenesis. ${ }^{4,5,14}$ In all 3 cases studied we observed the presence of out-of-frame alternative splicing variants, something that has not been previously reported ${ }^{7-}$ ${ }^{13}$ and whose biological relevance is not clear.
Characterization of MLL-SEPT6 genomic breakpoints The genomic breakpoints in all cases occurred in the MLL $8.3 \mathrm{~kb}$ breakpoint cluster region (BCR) and in SEPT6 intron 1 (Online Supplementary Figure 2). In patient 1 , a total of six suggestive HN-PCR fragments were gel extracted and sequenced. Sequencing of the amplification products showed that the breakpoint was located $231 \mathrm{bp}$ downstream of MLL exon 8 and 476 bp downstream of SEPT6 exon 1 (Online Supplementary Figure 2D). The HN-PCR study of case 2 revealed a total of 11 suggestive HN-PCR fragments that were gel extracted and sequenced. Sequencing analysis showed that the genomic breakpoints were located 629634 bp downstream of MLL exon 6 and 14410_14415 bp upstream of SEPT6 exon 2 (Online Supplementary Figures $2 B$ and $2 E$ ). In this case, the exact position of the genomic breakpoint could not be determined due to the presence of an identical 5-bp microhomology sequence (TGGGA) at the MLLSEPT6 genomic junction. In patient 3 , an LD-PCR fragment of $2179 \mathrm{bp}$ was detected (Online Supplementary Figure 2C). Interestingly, partial direct sequencing of the amplification product revealed the

Table 1. Clinical, karyotyping, FISH and RT-PCR data on all known acute myeloid leukemia-patients with MLL-SEPT6, and classification of the fusion variants.

\begin{tabular}{|c|c|c|c|c|c|c|c|c|}
\hline Patient & $\begin{array}{l}\text { Age } \\
\text { (mo.) }\end{array}$ & Sex & Diagnosis & Karyotype & FISH & $\begin{array}{c}\text { RT-PCR } \\
\text { (MLL/SEPT6 fusion) }\end{array}$ & Type & Reference \\
\hline 1 & 17 & $\mathrm{~F}$ & AML-M2 & $47, X, \operatorname{add}(X)(p 11),+6, \operatorname{add}(11)(q 23)[20]$ & MLL & $\begin{array}{l}\text { exon } 7 / \text { exon } 2 \\
\text { exon } 8 / \text { exon } 2 \\
\text { exon } 5-7 / \text { exon } 2\end{array}$ & $\begin{array}{l}\text { Type II } \\
\text { Type I } \\
\text { Out-of-Frame }\end{array}$ & Present study \\
\hline 2 & 12 & M & AML & $46, Y, t(X ; 11)(q 24 ; q 23)[11]) / 46, X Y[9]$ & MLL & $\begin{array}{l}\text { exon 6/exon } 2 \\
\text { exon } 5 / \text { exon } 2\end{array}$ & $\begin{array}{c}\text { Type IV } \\
\text { Out-of-Frame }\end{array}$ & Present study \\
\hline 3 & 0 & M & AML & 46,Y,ins(X;11)(q24;q13q23)[11] & MLL & $\begin{array}{l}\text { exon } 7 / \text { exon } 2 \\
\text { exon } 5-7 / \text { exon } 2\end{array}$ & $\begin{array}{c}\text { Type II } \\
\text { Out-of-Frame }\end{array}$ & Present study \\
\hline 4 & 6 & $\mathrm{~F}$ & AML-M2 & $46, X, \operatorname{ins}(X ; 11)(q 24 ; q 23)$ & MLL & exon 8/exon 2 & Type I & 8 \\
\hline 5 & 20 & $\mathrm{~F}$ & AML-M4 & $\begin{array}{l}\text { 47,X,der(X)t(X;11)(q22;q23)t(3;11)(p21;q12), } \\
\text { der(3)t(3;11)(p21;q23)t(X;11)(q22;q25), } \\
\text { +6,der(11)del(11)(q12?qter) }\end{array}$ & MLL & exon 7/exon 2 & Type II & 9 \\
\hline 6 & 10 & M & AML-M2 & 46,Y,t(X;11)(q22;q23)[25]/46,XY[5] & Not done & exon 8/exon 2 & Type I & 9 \\
\hline 7 & 3 & $\mathrm{~F}$ & AML-M2 & $\begin{array}{l}46, X X, t(5 ; 11)(q 13 ; q 23)[6] / 46, \\
\text { idem,add(X)(q22)[12] }\end{array}$ & MLL & $\begin{array}{l}\text { exon } 7 / \text { exon } 2 \\
\text { exon } 8 / \text { exon } 2\end{array}$ & $\begin{array}{l}\text { Type II } \\
\text { Type I }\end{array}$ & 7 \\
\hline 8 & 7 & M & AML-M2 & $46, X Y[20]$ & MLL & exon 7/exon 2 & Type II & 7 \\
\hline 9 & 6 & $\mathrm{~F}$ & AML-M1 & 46,X,add(X)(q2?),del(11q?)[20] & MLL & $\begin{array}{l}\text { exon } 7 / \text { exon } 2 \\
\text { exon } 8 / \text { exon } 2\end{array}$ & $\begin{array}{l}\text { Type II } \\
\text { Type I }\end{array}$ & 7 \\
\hline 10 & 29 & M & AML-M5 & 46,Y,ins(X;11)(q24;q23q13)[13]/46,XY[7] & MLL & exon 7 /exon 2 & Type II & 11 \\
\hline 11 & 8 & M & AML-M4 & $46, X Y$ & Not done & exon 8/exon 2 & Type I & 10 \\
\hline 12 & 13 & M & AML-M4 & $\begin{array}{l}\text { 46,Y,ins(11;X)(q23;q24q22) } \\
{[14] / 46, \text { idem,i(10)(q10)[6] }}\end{array}$ & MLL & exon 9 / exon 2 & Type III & 12 \\
\hline 13 & 26 & $\mathrm{~F}$ & AML-M4 & 46,XX,t(11;17)(q23;q?25)[20] & MLL & $\begin{array}{l}\text { exon } 7 / \text { exon } 2 \\
\text { exon } 8 / \text { exon } 2\end{array}$ & $\begin{array}{l}\text { Type II } \\
\text { Type I }\end{array}$ & 13 \\
\hline
\end{tabular}


same genomic breakpoint junction as detected in patient 1 , with fusion of nucleotide 231 downstream of $M L L$ exon 8 with nucleotide 476 downstream of SEPT6 exon 1 (Online Supplementary Figure 2D).

We searched for topoisomerase II consensus cleavage sites in the vicinity of the breakpoint regions in MLL introns 6 and 8 and SEPT6 intron 1. We found one sequence with $100 \%$ homology with the topoisomerase II consensus cleavage site located in SEPT6 intron 1 (GTTTTCCTGTTGTTGTTT), nucleotide position 9533_9550 bp downstream of SEPT6 exon 1. We also searched the breakpoint junctions (15 bp either side) for repetitive DNA sequence elements and motifs known to be associated with site specific recombination, cleavage, and gene rearrangement, but none could be found. Translocations may or may not involve gain or loss of genetic material at the genomic breakpoint junctions. Patients 1 and 3 , as well as the two previously reported cases, showed no nucleotide(s) deletion or duplication at the breakpoint junction. ${ }^{9,10}$ In our patient 2 , the exact position of the genomic breakpoint could not be determined due to an identical 5-bp microhomology region at the MLL-SEPT6 genomic junction, so it is unknown whether duplications and/or deletions occurred in this particular patient. The identification of identical microhomologies at genomic junctions suggests that the non-homologous DNA end-joining (NHEJ) pathway may be involved in this rearrangement. ${ }^{15}$ In patients 1 and 3 , the genomic junction mapped near a 484 bp LINE1 repeat in MLL intron 8, whereas the genomic breakpoint in SEPT6 intron 1 mapped near two GC-rich low complexity repeats. In patient 2, the MLL intron 6 genomic breakpoint occurred inside a $298 \mathrm{bp}$ Alu repeat, whereas the breakpoint junction in the SEPT6 intron 1 mapped near a 300 bp Alu repeat. Although repetitive sequences may occur near or spanning breakpoint junctions by chance, it is plausible that introns with a high density of repetitive sequences, such as SEPT6 intron 1, are vulnerable to breaking and non-homologous pairing that can lead to gene fusions such as MLL-SEPT6. Strikingly, although the breakpoints in the large SEPT6 intron 1 seem to be distributed all over the intronic region (our patient 2, and cases 6 and 11 in the literature; Table 1), patients 1 and 3 showed exactly the same genomic breakpoint both in MLL and SEPT6. Since the genomic breakpoint junctions in these 2 patients were cloned by different methods (HN-PCR and LD-PCR), on separate occasions, and taking the strictest anti-contamination measures, these findings can only be explained by the presence of a hot-spot for recombination at the said sites. Supporting this hypothesis, in addition to the above-mentioned high density of repetitive sequences in SEPT6 intron 1, is the detection of a topoisomerase II consensus site-specific cleavage in the same intron. Identical genomic breakpoints or breakpoint clustering within very narrow regions have been reported before, namely in MLL-AF4, ${ }^{16} M L L-A F 9,{ }^{17}$ and TCF3-PBX $1^{18}$ leukemias. Interestingly, the presence of an $M L L$ intron 8 genomic breakpoint in patient 3 does not seem to translate into fusion transcripts that include $M L L$ exon 8 , since the only in-frame fusion transcript detected showed a fusion between MLL exon 7 and SEPT6 exon 2. Splicing of $M L L$ exon 8, which includes the first of the four zinc fingers of the first zinc finger domain of the $M L L$ gene, has been previously described in acute leukemia with $M L L$ rearrangements, both in cases with translocation $\left[(\mathrm{t}(4 ; 11), \mathrm{t}(9 ; 11) \text {, and } \mathrm{t}(11 ; 19)]^{19,20}\right.$ and tandem duplication, ${ }^{21}$ changing the structural and possibly the functional features of the first zinc finger region of the MLL protein.

The MLL genomic breakpoints in MLL-SEPT6 AML patients seem to occur preferentially in the telomeric half (between introns 7 and 11) of the MLL BCR. This is characteristic of infant AML (the MLL-SEPT6 cases with genomic breakpoint characterization have an age at diagnosis from 0 to 17 months) and topoisomerase II inhibitor-related secondary leukemia, and a putative association with in utero exposure to topoisomerase II inhibitors has been hypothesized. ${ }^{22}$ The detection of a topoisomerase II recognition sequence in SEPT6 intron 1 also supports the hypothesis that exposure to topoisomerase II inhibitors, can result in double-strand DNA breaks that trigger the error-prone non-homologous end-joining pathway, which in turn can lead to formation of the MLL-SEPT6 fusion oncogene.

\section{Authorship and Disclosures}

NC designed and performed the research, analyzed the data and wrote the paper. FM and JS performed the research, analyzed the data and wrote the paper. MP, $\mathrm{CC}, \mathrm{SL}$, and SB performed the research and analyzed the data. LN, AG, and AEA clinically assessed the patients. SH and MRT analyzed the data and wrote the paper. The authors reported no potential conflicts of interest.

\section{References}

1. Rowley JD. Chromosome translocations: dangerous liaisons revisited. Nat Rev Cancer 2001;1:245-50.

2. Nakamura T, Mori T, Tada S, Krajewski W, Rozovskaia T, Wassell $\mathrm{R}$, et al. ALL- 1 is a histone methyltransferase that assembles a supercomplex of proteins involved in transcriptional regulation. Mol Cell 2002; 10:1119-28.

3. Daser A, Rabbitts TH. The versatile mixed lineage leukaemia gene MLL and its many associations in leukaemogenesis. Semin Cancer Biol 2005 15:175-88.

4. Meyer C, Schneider B, Jakob S Strehl S, Attarbaschi A, Schnittger S, et al. The MLL recombinome of acute leukemias. Leukemia 2006;20 777-84.

5. Cerveira N, Correia C, Bizarro S, Pinto C, Lisboa S, Mariz JM, et al. SEPT2 is a new fusion partner of MLL in acute myeloid leukemia with $\mathrm{t}(2 ; 11)(\mathrm{q} 37 ; \mathrm{q} 23)$. Oncogene 2006;25:
6147-52

6. Russell SE, Hall PA. Do septins have a role in cancer? Br J Cancer 2005; 93 499-503.

7. Ono R Taki T, Taketani T, Kawaguchi $\mathrm{H}$, Taniwaki $\mathrm{M}$, Okamura $\mathrm{T}$, et al. SEPTIN6, a human homologue to mouse Septin6, is fused to MLL in infant acute myeloid leukemia with complex chromosomal abnormalities involving $11 \mathrm{q} 23$ and Xq24. ties involving 11q23 and
Cancer Res 2002;62:333-7.

8. Borkhardt A, Teigler-Schlegel A Fuchs U, Keller C, König M, Harbott 
J, et al. An ins(X;11)(q24;q23) fuses the MLL and the Septin 6/KIAA0128 gene in an infant with AML-M2. gene in an infant with AML-M2. Gene 82 -8

9. Slater DJ, Hilgenfeld E, Rappaport EF, Shah N, Meek RG, Williams WR, et al. MLL-SEPTIN6 fusion recurs in novel translocation of chromosomes $3, \mathrm{X}$, and 11 in infant acute myelomonocytic leukaemia and in $\mathrm{t}(\mathrm{X} ; 11)$ in infant acute myeloid leukaemia and MLL genomic breakpoint in complex MLL-SEPTIN6 rearrangement is a DNA topoisomerase II cleavage site. Oncogene $2002 ; 21$. cleavage

10. Fu JF, Liang DC, Yang CP, Hsu JJ Shih LY. Molecular analysis o $\mathrm{t}(\mathrm{X} ; 11)(\mathrm{q} 24 ; \mathrm{q} 23)$ in an infant with AML-M4. Gene Chromosomes AML-M4. Gene Chr

11. Kim HJ, Ki CS, Park Q, Koo HH, Yoo KH, Kim EJ, et al MLL/SEPTIN6 chimeric transcrip from inv ins $(X ; 11)(q 24 ; q 23 q 13)$ in acute monocytic leukemia: report of a case and review of the literature. Gene Chromosomes Cancer 2003; 38:8-12.

12. Kadkol SS, Bruno A, Oh S, Schmidt ML, Lindgren V. MLL-SEPT6 fusion transcript with a novel sequence in an infant with acute myeloid leukemia. Cancer Genet Cytogenet 2006;168:162-7

13. Strehl S, König M, Meyer C,
Schneider B, Harbott J, Jäger U, et al. Molecular dissection of $t(11 ; 17)$ in acute myeloid leukemia reveals variety of gene fusions with heterogeneous fusion transcripts and multiple splice variants. Gene Chromosomes Cancer 2006;45:1041-9.

14. van Binsbergen E, de Weerdt $O$ Buijs A. A new subtype of MLLSEPT2 fusion transcript in therapyrelated acute myeloid leukemia with $\mathrm{t}(2 ; 11)(\mathrm{q} 37 ; \mathrm{q} 23)$ : a case report and literature review. Cancer Genet Cytogenet 2007;176:72-5

15. Poirel H, Rack K, Delabesse E Radford-Weiss I, Troussard X, Debert C, et al. Incidence and characterization of MLL gene (11q23) rearrangements in acute myeloid leukemia M1 and M5. Blood 1996; 87:2496-505.

16. Gu Y, Nakamura T, Alder H, Prasad $\mathrm{R}$, Canaani $\mathrm{O}$, Cimino $\mathrm{G}$, et al. The $\mathrm{t}(4 ; 11)$ chromosome translocation of human acute leukemias fuses the ALL-1 gene, related to Drosophila trithorax to the AF-4 gene Cell trithorax, to the

17. Langer T, Metzler M, Reinhardt D Viehmann S, Borkhardt A, Reiche $\mathrm{M}$, et al. Analysis of $\mathrm{t}(9 ; 11)$ chromosomal breakpoint sequences in childhood acute leukemia: almost identical MLL breakpoints in therapy-related AML after treatment without etoposides. Gene Chromosomes Cancer 2003;36:393-401.
18. Paulsson K, Jonson T, Ora I, Olofsson T, Panagopoulos I Johansson B. Characterisation of genomic translocation breakpoints and identification of an alternative TCF3/PBX1 fusion transcript in $\mathrm{t}(1 ; 19)$ (q23;p13)-positive acute lymphoblastic leukaemias. Br J Haematol 2007;138:196-201.

19. Corral J, Forster A, Thompson S Lampert F, Kaneko Y, Slater R, et al. Acute leukemias of different lineages have similar MLL gene fusions encoding related chimeric proteins resulting from chromosomal translocation. Proc Natl Acad Sci USA 1993;90:8538-42.

20. Yamamoto K, Seto M, Komatsu $H$ Iida S, Akao Y, Kojima S, et al. Two distinct portions of LTG19/ENL at $19 \mathrm{p} 13$ are involved in $t(11 ; 19)$ leukemia. Oncogene 1993;8:2617. 25.

21. Yu M, Honoki K, Andersen J, Paietta E, Nam DK, Yunis JJ. MLL tandem duplication and multiple splicing in adult acute myeloid leukemia with normal karyotype. Leukemia 1996; 10:774-80.

22. Cimino G, Rapanotti MC, Biondi A Elia L, Lo Coco F, Price C, et al. Infant acute leukemias show the same biased distribution of ALL1 gene breaks as topoisomerase II related secondary acute leukemias. Cancer Res 1997;57:2879-83. 


\title{
Molecular characterization of the MLL-SEPT6 fusion gene in acute myeloid leukemia: identification of novel fusion transcripts and cloning of genomic breakpoint junctions
}

\author{
Nuno Cerveira, ${ }^{1}$ Francesca Micci, ${ }^{2}$ Joana Santos, ${ }^{1}$ Manuela Pinheiro, ${ }^{1}$ Cecília Correia, ${ }^{1}$ \\ Susana Lisboa, ${ }^{1}$ Susana Bizarro, ${ }^{1}$ Lucília Norton, ${ }^{3}$ Anders Glomstein, ${ }^{4}$ Ann E. Åsberg, ${ }^{5}$ \\ Sverre Heim, ${ }^{2,6}$ and Manuel R. Teixeira ${ }^{1,7}$ \\ ${ }^{1}$ Department of Genetics, Portuguese Oncology Institute, Porto, Portugal; ${ }^{2}$ Section for Cancer Cytogenetics, \\ Department of Medical Genetics, Radiumhospitalet-Rikshospitalet Medical Center, Oslo, Norway; ${ }^{3}$ Department of \\ Pediatrics, Portuguese Oncology Institute, Porto, Portugal; ${ }^{4}$ Department of Pediatrics, Radiumhospitalet- \\ Rikshospitalet Medical Center, Oslo, Norway; ${ }^{5}$ Department of Pediatrics, St Olav University Hospital, Trondheim, \\ Norway; ${ }^{6}$ Faculty Division, The Norwegian Radium Hospital, Medical Faculty, University of Oslo, Norway and \\ ${ }^{7}$ Biomedical Sciences Institute (ICBAS), University of Porto, Porto, Portugal
}

Citation: Cerveira N, Micci F, Santos J, Pinheiro M, Correia C, Lisboa S, Bizarro S, Norton L, Glomstein A, Åsberg AE, Heim S, and Teixeira MR. Molecular characterization of the MLL-SEPT6 fusion gene in acute myeloid leukemia: identification of novel fusion transcripts and cloning of genomic breakpoint junctions. Haematologica 2008; doi: 10.3324/haematol.12594

\section{Design and Methods}

\section{Patients}

The study comprised three cases of AML in which an Xq2411 q23 rearrangement was detected by karyotyping of the leukemic cells. A summary of the clinical, cytogenetic, and molecular genetic data is provided in Online Supplementary Table S1.

\section{Patient 1}

A 17-month-old girl was admitted to the Portuguese Oncology Institute (Porto, Portugal) in September 2006 because of mucosal and cutaneous pallor and right leg pain, with refusal to walk. Peripheral blood analysis revealed leukocytosis, anemia, and thrombocytopenia, with $28 \%$ circulating blasts. The bone marrow was hypercellular containing $82 \%$ blasts mainly positive for CD4, CD11b, CD11c, CD15, CD33, CD64, CD65, HLA-DR, and LIS, and negative for CD2, cCD3, CD13, CD14, CD16, CD34, CD36, CD56, CD79a, CD117, and TdT. A diagnosis of acute myeloblastic leukemia with maturation was established. Cytogenetic analysis showed evidence of a rearrangement involving the long arm of chromosome 11 (11q23), with additional material of unknown origin in $11 \mathrm{q} 23$ and Xp11. She was treated according to the ELAM 02 protocol (aracytine, mitoxantrone and methotrexate) and entered complete remission after induction chemotherapy. In April 2007, she was submitted to allogeneic bone marrow transplantation and has no evidence of disease at the time of writing.

\section{Patient 2}

A previously healthy, 12-month-old boy was admitted to the Rikshospitalet Department of Paediatrics (Oslo, Norway) in March 1997 after a short history of skin bleedings. Peripheral blood analysis revealed leukocytosis $(90 \%$ myeloblasts), anemia and thrombocytopenia. The bone marrow was hypercellular with more than $90 \%$ blasts that were positive for CD45, CD33, CD15, CD13 and HLA-DR and a diagnosis of acute myeloid leukemia was made. Cytogenetic analysis of bone marrow cells revealed a clonal $\mathrm{t}(\mathrm{X} ; 11)(\mathrm{q} 24 ; \mathrm{q} 23)$. The spinal fluid contained $14 \times 10^{9} / \mathrm{L}$ leukocytes, morphologically described as reactive; immunocytochemistry was unsuccessful. The patient was treated according to the Nordic protocol NOPHO-AML $93,{ }^{1}$ and went into complete remission after the first course containing intrathecal methotrexate and intravenous 6-thioguanine, cytarabine, etoposide and doxorubicin. This treatment was discontinued in August 1997 after a total of 6 courses without major complications. In April 2000, he was readmitted with a bone marrow relapse after a few weeks with infections and falling blood values. The leukemic blasts showed the same markers as in 1997.

He was reinduced with the same NOPHO protocol and went into second complete remission after the first course. In September 2000, after two more courses, he underwent bone marrow transplantation from his older, HLA-identical sister donor. There were no procedural complications and at last follow-up, in October 2007, he was still in second complete remission. The boy is active and with no sequelae.

\section{Patient 3}

This patient was a newborn boy, the third child of healthy parents, delivered at term in October 1997 after an uncomplicated pregnancy. The boy was transferred to the Department of Paediatrics, St Olav University Hospital (Trondheim, Norway) on suspicion of congenital leukemia. Initial physical examination revealed widespread, firm, bluish cutaneous nodules, petecchiae and hepatosplenomegaly. The peripheral blood values were $\mathrm{Hb} 16.2 \mathrm{~g} / \mathrm{dL}$, platelets $100 \times 10^{9} / \mathrm{L}$ and $\mathrm{WBC}$ $340 \times 10^{9} / \mathrm{L}$ ( $90 \%$ with monoblastic morphology). The cerebrospinal fluid contained $101 \times 10^{9} / \mathrm{L}$ cells that by flow cytometric analysis were shown to be monoblasts. Immunophenotyping of peripheral blood confirmed a $90 \%$ population of cells expressing CD33, CD13, CD15, CD14 and partly CD24 and HLA-DR. Because of severe tumor lysis syn- 
MATERIAL AND METHODS, RESULTS AND DISCUSSION

Supplementary Table S1. Sequence of the primers used for the RNA and DNA analyses.

\begin{tabular}{|c|c|c|c|}
\hline Primer & Target & Sequence & Position \\
\hline MLL-E5S & MLL exon 5 & 5'-GAGGATCCTGCCCCAAAGAAAAG-3' & 3771_3793 \\
\hline MLL-E6S & $M L L$ exon 6 & 5'-GCAAACAGAAAAAAGTGGCTCCCCG-3' & 4048_4072 \\
\hline MLL-I6S-In & MLL exon6/intron 6 & 5'-AAACCAAAAGAAAAGGTGAGGAGA-3' & 4095_4109/1_9 \\
\hline MLL-E7S-01 & $M L L$ exon 7 & 5'-CCTCCGGTCAATAAGCAGGAGAATG-3' & 4119_4143 \\
\hline MLL-E7S-02 & MLL exon 7 & 5'-TCAGCACTCTCTCCAATGG-3' & 4162_4180 \\
\hline MLL-E8S & MLL exon 8 & 5'-GCAGAAAATGTGTGGGAGATGGGAG-3' & 4254_4278 \\
\hline MLL-E8S-In & MLL exon 8 & 5'-TTCСATAACACCCAGGGTGGT-3' & 4300_4321 \\
\hline MLL-I6-01-0 & $M L L$ intron 6 & 5'-CAAAGCAAAACACTGTCTCCAAAA-3' & 419_442 \\
\hline MLL-16-01-In & $M L L$ intron 6 & 5'-AAAATTAGGCTTGGCAAGGC-3' & $443-463$ \\
\hline MLL-16-02-0 & MLL intron 6 & 5'-GTTCTतCTTGாGCTाTCCC-3' & 1079_1101 \\
\hline MLL-16-02-In & $M L L$ intron 6 & 5'-TGGCCCCACATGாTCTAGC-3' & 1109_1127 \\
\hline MLL-I8-01-0 & MLL intron 8 & 5'AGAAATAAATACATGTGGGTGGCA-3' & 438_462 \\
\hline MLL-I8-01-In & $M L L$ intron 8 & 5'-GAGGTGAAGGGAGGGTGTCTG-3' & 467_487 \\
\hline MLL-18-02-0 & $M L L$ intron 8 & 5'-CAGGCGGATCACAAGGTCA-3' & 878_896 \\
\hline MLL-18-02-In1 & MLL intron 8 & 5'-CACAGTGAAACCCCGTCTCTATT-3' & 921_943 \\
\hline MLL-18-02-In2 & $M L L$ intron 8 & 5'-TCTGGAAGGATTCACACCAAAA-3' & 1331_1352 \\
\hline MLL-18-03-0 & $M L L$ intron 8 & 5'-TGTTGAGCAGTCAGTGAGACACAA-3' & 1970_1993 \\
\hline MLL-18-03-In1 & $M L L$ intron 8 & 5'-CCCTGCCCACTTGCCAT-3' & 2012_2028 \\
\hline MLL-18-03-In2 & MLL intron 8 & 5'-TGCCTGCACTGCACTCCTAA-3' & 2394_2413 \\
\hline MLL-18-04-0 & MLL intron 8 & 5'-GAGAATCGCTTGAACCCAGG-3' & 3113_3132 \\
\hline MLL-18-04-In & $M L L$ intron 8 & 5'-GATCGCACCACTGCACCC-3' & 3156_3173 \\
\hline SEPT6-E2AS-01 & SEPT6 exon 2 & 5'-CCTGGCTGACGGACTTATCACC-3' & $361 \_383$ \\
\hline SEPT6-E2AS-02 & SEPT6 exon 2 & 5'-GCACAGGATGTTGAAGCAGA-3' & $387 \_406$ \\
\hline SEPT6-E2AS-03 & SEPT6 exon 2 & 5'-TGCCCAAАCCTGTCTCTCC-3' & $410 \_429$ \\
\hline SEP06-I2LDAS-01 & SEPT6 intron 1 & 5'-CAGCTATACCATCTCTGAAATGCAGGT-3' & $1657 \_1683$ \\
\hline SEP06-I2LDAS-02 & SEPT6 intron 1 & 5'-GGCCGATCAGTGCCCAGTGAATATGTG-3' & 4987_5013 \\
\hline SEP06-I2LDAS-03 & SEPT6 intron 1 & 5'-ATAGATCGACCTСССТАСGACTCTCTCCC-3' & 7718_7747 \\
\hline SEP06-I2LDAS-04 & SEPT6 intron 1 & 5'-GCAAAGGTAGGAAGGACAGAAGGACAC-3' & 11924_11950 \\
\hline SEP06-I2LDAS-05 & SEPT6 intron 1 & 5’-CCGTCAGCTGGAAATCACAGATTCTT-3' & 17222_17248 \\
\hline SEP06-I2AS-01 & SEPT6 intron 1 & 5'-ATACACACACAGACGCAGTCACAT-3' & 528_551 \\
\hline SEP06-I2AS-02 & SEPT6 intron 1 & 5'-CACACCACAGAGGTGAGCACA-3' & $660 \_680$ \\
\hline SEP06-I2AS-03 & SEPT6 intron 1 & 5'-CACCTACAGGCCAGCCAACT-3' & $751-770$ \\
\hline SEP06-I2AS-04 & SEPT6 intron 1 & 5'-GCATCATCACAGAGAATGTCCC-3' & 1531_1552 \\
\hline SEP06-I2AS-05 & SEPT6 intron 1 & 5'-GGAGAATCGCTTGAACCTGG-3' & $2427 \_2446$ \\
\hline SEP06-I2AS-06 & SEPT6 intron 1 & 5'-CACCATGTTGGCCAGGCT-3' & 3132_3149 \\
\hline SEP06-I2AS-07 & SEPT6 intron 1 & 5'-GGCTTGCCCTGTGCCTI-3' & 3767_3783 \\
\hline SEP06-I2AS-08 & SEPT6 intron 1 & 5'-AGTITGGGAATACCTIITICCAGAG-3' & 5377_5401 \\
\hline SEP06-I2AS-09 & SEPT6 intron 1 & 5'-TCGTATCACCCACTGACCAGC-3' & 6034_6054 \\
\hline SEP06-I2AS-10 & SEPT6 intron 1 & 5'-TGGCTTGATGCTGGTCAGG-3' & $7332 \_7350$ \\
\hline SEP06-I2AS-11 & SEPT6 intron 1 & 5'-GGCAATATCTGAAGGGTTGTTTCT-3' & $7782 \_7805$ \\
\hline SEP06-I2AS-12 & SEPT6 intron 1 & 5'-GAGAATCGCTTGAACGCAGG-3' & 9896_9915 \\
\hline SEP06-I2AS-13 & SEPT6 intron 1 & 5'-TGGGAACTGAGGGTGCATCT-3' & 10267_10286 \\
\hline SEP06-I2AS-14 & SEPT6 intron 1 & 5'-GAGTAGTCGGTATGCTTCCCTATTG-3' & 10812_10836 \\
\hline SEP06-I2AS-15 & SEPT6 intron 1 & 5'-TCAGTCCGCATTGTCAGAGTT-3' & 11957_11978 \\
\hline SEP06-I2AS-16 & SEPT6 intron 1 & 5'-CCACGCCCAGGTAATTाTG-3' & 12695_12714 \\
\hline SEP06-I2AS-17 & SEPT6 intron 1 & 5'-CTAGGAGCAGGAAGACATAGGAGG-3' & 13639_13662 \\
\hline SEP06-I2AS-18 & SEPT6 intron 1 & 5'-AACAAAGTAAGATGCAAGATTCCCA-3' & 14411_14435 \\
\hline SEP06-I2AS-19 & SEPT6 intron 1 & 5'-TGTGGTGAGCATTCAATCAGC-3' & 16021_16041 \\
\hline SEP06-I2AS-20 & SEPT6 intron 1 & 5’-ССТССАСАTCTGCCATCTGA-3' & 17018_17038 \\
\hline
\end{tabular}

E: exon; I: intron; S: sense; AS: antisense; O: outer; In: inner.

drome and respiratory insufficiency, initially no bone marrow sample was taken, but cytogenetic analysis of cells in the peripheral blood revealed an insertion ins(X;11)(q24;q13q23). A diagnosis of acute myeloid leukemia was made and treatment was started according to the NOPHO-AML 93 protocol with a prophase of low-dose cytarabine and intrathecal methotrexate. ${ }^{1}$ Remission was achieved after the first A1 block. Because of prolonged pancytopenia during the treatment period, chemotherapy dosages had to be reduced. CNS-directed therapy was continued for one year. One year after systemic chemotherapy had been stopped, the boy experienced a local bone marrow relapse, confirmed by immunophenotyping. He went into a second complete remission after one course of cytarabine, etoposide, thioguanine and intrathecal methotrexate, and continued treatment according to NOPHO-AML 93 until he received a bone marrow transplantation five months later. Only minor graft-versus-host disease was subsequently observed and he is now, eight years later, doing well but is being evaluated for secondary short stature.

\section{Chromosome banding and molecular cytogenetics}

The diagnostic bone marrow samples (from patient 3 , the diagnostic culture was of peripheral blood blasts) were cultured for 24 hours in RPMI 1640 medium with GlutaMAX-I (Invitrogen, London, UK) supplemented with 20\% fetal bovine serum (Invitrogen, London, UK). Chromosome preparations were made by standard methods and banded by trypsinLeishman. Karyotypes were described according to the International System for Human Cytogenetic Nomenclature. ${ }^{2}$

FISH analysis for possible MLL rearrangement was performed using the LSI MLL Dual-Colour, Break-Apart Probe (Vysis, Downers Grove, USA) according to the manufacturer's instructions. In 2 cases (patients 2 and 3 ), initial characterization of the chromosomal breakpoints in the long arm of the X chromosome was performed using bacterial artificial chromosome (BAC) clones RP11-379J1 (maps to the SEPT6 gene) and CTD-2334F19 (maps to the 5' region of the SEPT6 gene). The clones were retrieved from the RP11 Human BAC library and Cal Tech Human BAC library D (P. de Jong libraries http:/lbacpac.choriorg/home.htm. 
They were cultured in selected media and DNA was isolated following a standard protocol consisting of alkaline lysis, neutralization, and ethanol precipitation.

\section{RNA and DNA extraction}

High molecular weight DNA and RNA were extracted from the bone marrow sample (patient 1) or from fixed cell suspension remaining after completion of the cytogenetic analysis (patients 2 and 3; cells from peripheral blood) using $1 \mathrm{~mL}$ of Tripure isolation reagent (Roche Diagnostics, Indianapolis, USA) according to the manufacturer's instructions.

\section{Reverse-transcription polymerase chain-reaction (RT-PCR)}

RT-PCR for the detection of MLL-SEPT6 fusion transcripts was performed as follows: for cDNA synthesis, $1 \mu \mathrm{g}$ of RNA was subjected to reverse transcription with random hexamers using the Superscript III First-Strand Synthesis System for RTPCR (Invitrogen, Carlsbad, USA) according to the manufacturer's instructions. Forward primers (MLL-E5S, MLL-E6S, MLLE7S-01, MLL-E7S-02, and MLL-E8S) for MLL exons 5, 6, 7, and 8 (GenBank accession no. NM_005933) have been previously described (Online Supplementary Table S1). ${ }^{3,4}$ Reverse primers
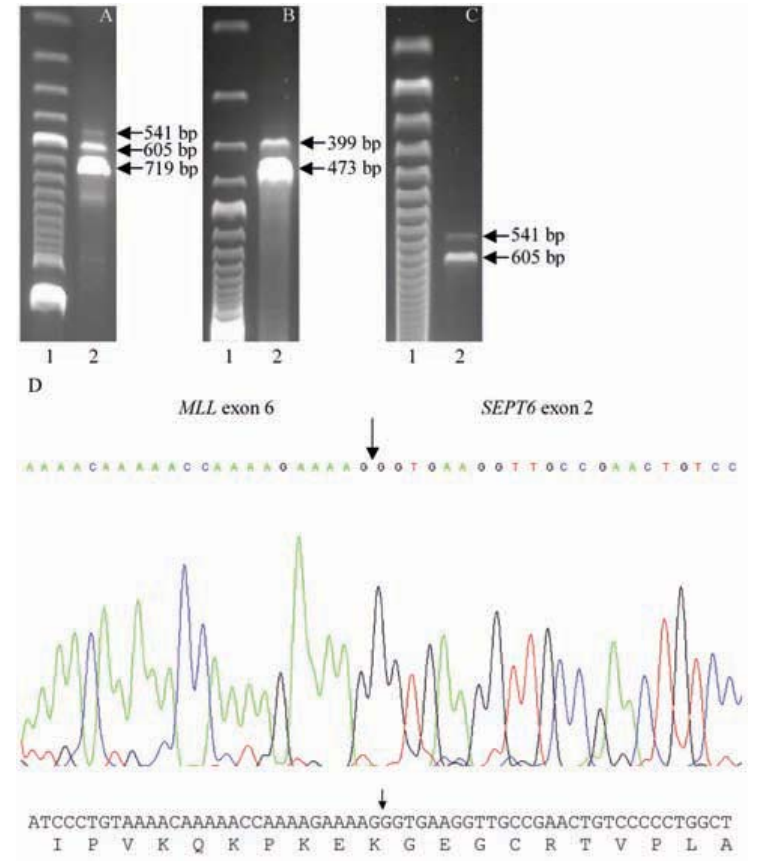

Supplementary Figure S1. MLL-SEPT6 fusion transcript analysis. (A) In case 1, three RT-PCR fragments were detected: a major fragment with $719 \mathrm{bp}$ (MLL exon 8 fused with SEPT6 exon 2), a minor fragment with 605 bp (MLL exon 7 fused with SEPT6 exon 2), and a faint band with 541 bp corresponding to out-of-frame fusion between MLL exon 7 and SEPT6 exon 2, with splicing of $M L L$ exon $6 .{ }^{1} 100$ bp molecular marker. (B) Case 2 RT-PCR analysis showed the presence of one major fragment of 473 bp (MLL exon 6 fused with SEPT6 exon 2) and a minor fragment of $399 \mathrm{bp}$ resulting from an out-of-frame fusion of MLL exon 5 to SEPT6 exon 2 . $^{1} 100 \mathrm{bp}$ molecular marker. (C) In case 3, two RT-PCR fragments of 605 bp and 541 bp were marker. (C) In case 3, two RT-PCR fragments of 605 be fusion between $M L L$ detected. Sequencing analysis revealed in both cases a fusion between 1 and frame splicing of MLL exon $6 .^{1} 50 \mathrm{bp}$ molecular marker. (D) Partial sequence of the junction of the novel MLL-SEPT6 chimeric mRNA (type IV) detected in case 2 , showing the nucleotide sequence of the fusion transcript. The arrow shows the in-frame fusion between MLL exon 6 and SEPT6 exon 2.
(SEPT6-E2AS-01, SEPT6-E2AS-02, and SEPT6-E2AS-03) for SEPT6 exon 2 were derived from the published sequence of SEPT6 mRNA with GenBank accession n. NM_145799 (Online Supplementary Table S1).

PCR reactions were performed in a $50 \mu \mathrm{L}$ reaction volume containing $2 \mu \mathrm{L}$ of synthesized cDNA, $5 \mu \mathrm{L}$ of $10 \times$ GeneAmp PCR buffer II (100 mM Tris- $\mathrm{HCl} \mathrm{pH} 8.3,500 \mathrm{mM} \mathrm{KCl})$ (Applied Biosystems, Foster City, USA), $5 \mu \mathrm{L}$ of $25 \mathrm{mM}$ $\mathrm{MgCl} 2,0.4 \mu \mathrm{L}$ dNTP mix (25 mM each dNTP) (Applied Biosystems, Foster City, USA), $0.4 \mathrm{mM}$ of each primer (Metabion, Martinsried, Germany), and 1 unit of AmpliTaq Gold DNA Polymerase (Applied Biosystems, Foster City, USA).

Reaction tubes were kept on ice at all times to prevent nonspecific amplification and incubated for 5 mins. at $94^{\circ} \mathrm{C}$, followed by 35 cycles of 30 secs. at $95^{\circ} \mathrm{C}, 1 \mathrm{~min}$. at $63^{\circ} \mathrm{C}$, and 1.5 mins. at $72^{\circ} \mathrm{C}$, followed by a final elongation of 10 mins. at $72^{\circ} \mathrm{C}$ on a GeneAmp PCR System 9700 (Applied BioSystems, Foster City, USA). Amplified products were analyzed on a $2 \%$ agarose gel (SeaKem LE Agarose, Rockland, USA) and the results were visualized in an image analyzer ImageMaster VDS (Amersham Biosciences, Little Chalfont, UK).
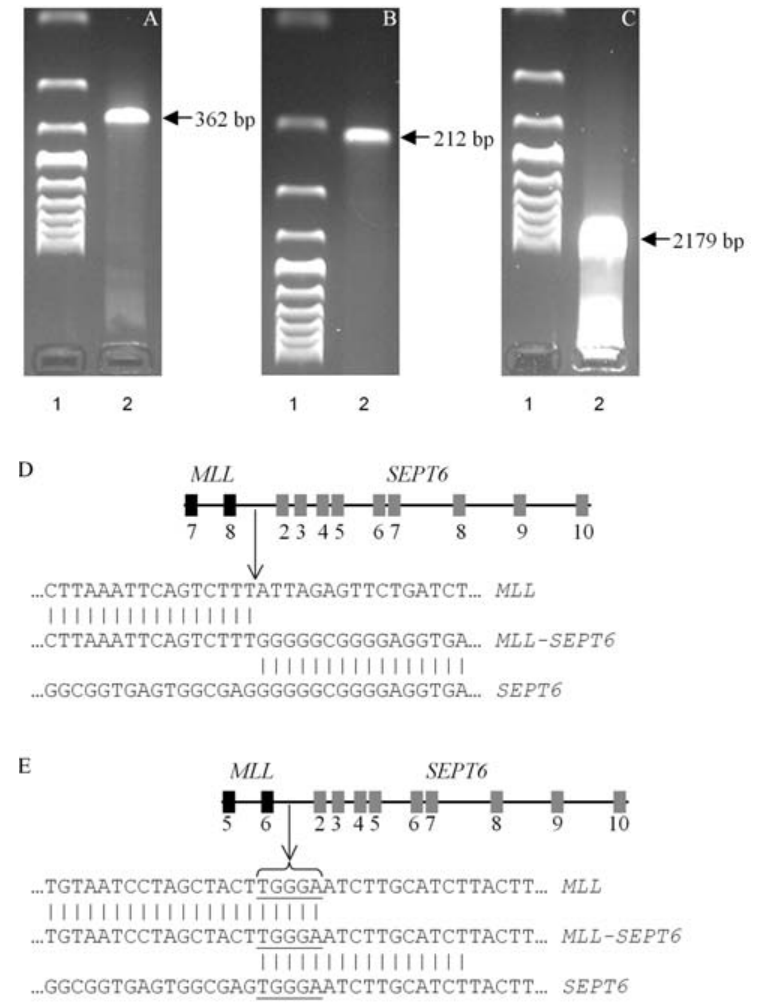

Supplementary Figure S2. MLL-SEPT6 genomic breakpoint analysis. (A) and (B) Detection by HN-PCR of the genomic breakpoints in patients 1 (362 bp fragment) and 2 (212 bp fragment) respectively. (C) LD-PCR detection of the genomic breakpoint in case 3 (2179 bp fragment). In all cases, a 100 bp molecular marker was used. ${ }^{1}$ (D) Schematic representation of the genomic breakpoint (arrow), nucleotide sequence, and corresponding sequences of (E) Schematic ruences of normal $M L L$ and SEPT6 genes in cases 1 and 3. (E) Schematic representathe genomic breakpoint, nucleotide sequence (arrow), and corresponding normal MLL and SEPT6 genes (arrow) in case 2. In this case, because of micro-homology at the genomic junction (underlined), we were not able to determine the origin of these 5 nucleotides. 


\section{Long-range polymerase chain reaction (LR-PCR)}

To characterize the genomic MLL-SEPT6 fusions, we used the $M L L$ exons 5, 6, 7, and 8 primers in combination with five additional primers (SEP06-I2LDAS-01, SEP06-I2LDAS-02, SEP06-I2LDAS-03, SEPO6-I2LDAS-04, and SEPO6-I2LDAS-05) located in the large (over $17 \mathrm{~Kb}$ ) SEPT6 intron 1 (Online Supplementary Table S1). LR-PCR, using the TripleMaster PCR System (Eppendorf, Hamburg, Germany), was performed in a $50 \mu \mathrm{L}$ reaction volume containing $100 \mathrm{ng}$ DNA, $5 \mu \mathrm{L}$ of $10 \mathrm{x}$ Tuning Buffer, $2.5 \mu \mathrm{L}$ dNTP mix (10 mM each dNTP) (GE Healthcare, Little Chalfont, UK), $0.4 \mathrm{mM}$ of each primer (Metabion, Martinsried, Germany), and 2 units of TripleMaster Polymerase Mix. Reaction tubes were kept on ice at all times to prevent non-specific amplification. They were then incubated for 3 mins. at $93^{\circ} \mathrm{C}$, followed by 10 cycles of 15 secs. at $93^{\circ} \mathrm{C}$, 30 secs. at $65^{\circ} \mathrm{C}$, and 10 mins. at $68^{\circ} \mathrm{C}$, followed by 27 cycles of 15 secs. at $93^{\circ} \mathrm{C}, 30$ secs. at $65^{\circ} \mathrm{C}$, and 10 mins. at $68^{\circ} \mathrm{C}$ with an increment of 20 secs. per cycle, on a GeneAmp PCR System 9700 (Applied BioSystems, Foster City, USA).

Amplified products were analyzed on a $0.8 \%$ agarose gel (SeaKem LE Agarose, Rockland, USA) and the results were visualized in an image analyzer ImageMaster VDS (Amersham Biosciences, Little Chalfont, UK).

\section{Hemi-nested polymerase chain reaction (HN-PCR)}

Since it was not possible to characterize the genomic breakpoint junctions in patients 1 and 2 by LR-PCR, an HN-PCR approach was developed. First-round PCR was performed using forward outer primers located in MLL exon/intron 6 (MLL-E6S, MLL-I6-01-O, and MLL-I6-02-O) (patient 2) or exon/intron 8 (MLL-I8-01-O, MLL-I8-02-O, MLL-I8-03-O, MLL-I8-04-O) (patient 1) and reverse primers located in SEPT6 intron 1/exon 2 (SEP06-I2AS-01, SEP06-I2AS-02, SEP06-I2AS03, SEP06-12AS-04, SEP06-12AS-05, SEP06-I2AS-06, SEP06I2AS-07，SEP06-I2AS-08，SEP06-I2AS-09，SEP06-I2AS-10, SEP06-I2AS-11, SEP06-I2AS-12，SEP06-12AS-13，SEPO6-I2AS14, SEP06-12AS-15, SEP06-12AS-16, SEPO6-I2AS-17, SEP06I2AS-18, SEP06-I2AS-19, and SEP06-I2AS-20) (Online Supplementary Table S1). Second-round PCR was performed with forward inner primers MLL-I6S-In, MLL-I6-01-In, and MLL-16-02-In (patient 2), or MLL-I8-01-In, MLL-I8-02-In1, MLL-I8-02-In2, MLL-I8-03-In1, MLL-I8-03-In2, MLL-I8-04-In (patient 1) and the same reverse primers as first-round PCR (Online Supplementary Table S1). PCR reactions were performed in a $50 \mu \mathrm{L}$ reaction volume containing $2 \mu \mathrm{L}$ of first-round PCR product, $5 \mu \mathrm{L}$ of $10 \mathrm{x}$ GeneAmp PCR buffer II (100 mM Tris-HCl pH 8.3, $500 \mathrm{mM} \mathrm{KCl}$ ) (Applied Biosystems, Foster City, USA), $5 \mu \mathrm{L}$ of $25 \mathrm{mM} \mathrm{MgCl2}, 0.4 \mu \mathrm{L}$ dNTP mix (25 mM each dNTP) (Applied Biosystems, Foster City, USA), $0.4 \mathrm{mM}$ of each primer (Metabion, Martinsried, Germany), and 1 unit of AmpliTaq Gold DNA Polymerase (Applied Biosystems, Foster City, USA). Reaction tubes were kept on ice at all times to prevent non-specific reactions and then incubated for $5 \mathrm{mins}$. at $94^{\circ} \mathrm{C}$, followed by 35 cycles of 30 secs. at $95^{\circ} \mathrm{C}, 1 \mathrm{~min}$. at $63^{\circ} \mathrm{C}$, and $1.5 \mathrm{mins}$. at $72^{\circ} \mathrm{C}$, followed by a final elongation of 10 mins. at $72^{\circ} \mathrm{C}$ on a GeneAmp PCR System 9700 (Applied BioSystems, Foster City, USA). Amplified products were analyzed on a $2 \%$ agarose gel (SeaKem LE Agarose, Rockland, USA) and the results were visualized in an image analyzer ImageMaster VDS (Amersham Biosciences, Little Chalfont, UK). Strict measures were taken to avoid problems associated with contamination.

\section{Sequencing}

Sequence analysis was directly performed on the amplified RT-PCR or PCR product by use of the BigDye Terminator Cycle Sequencing Chemistry (Applied Biosystems, Foster City, USA) on an automated sequencer ABI Prism 310 Genetic Analyser (Applied BioSystems, Foster City, USA) according to the manufacturer's instructions. When multiple bands were observed, gel band extraction and purification was performed with the illustra GFX PCR DNA and Gel Band Purification Kit (GE Healthcare, Little Chalfont, UK), again according to the manufacturer's instructions.

\section{Bioinformatic sequence analysis}

The presence of specific recombination-related DNA sequence motifs known to be associated with site-specific recombination, cleavage, and gene rearrangement, ${ }^{5,6}$ such as the topoisomerase II consensus cleavage site, VDJ recombination sequence, translin binding sequence, $\chi$-like sequence, and purine/pyrimidine repeat regions, was investigated with SEO tools and RepeatMasker.,

\section{References}

1. Lie SO, Abrahamsson J, Clausen N, Forestier E, Hasle H, Hovi L, et al. Treatment stratification based on initial in vivo response in acute myeloid leukaemia in children without Down's syndrome: results of NOPHO-AML trials. Brit J Haematol 2003;122:217-25.

2. Shaffer LG, Tommerup N ISCN 2005 An International System for Human Cytogenetic Nomenclature. Basel, Switzerland: Karger 2005.

3. Yamamoto K, Seto M, Iida S, Komatsu H, Kamada N, Kojima S, et al. A reverse transcriptase-polymerase chain reaction detects heterogeneous chimeric mRNAs in leukemias with 11q23 abnormalities. Blood 1994;83:2912-21.

4. Poirel H, Rack K, Delabesse E, Radford-Weiss I, Troussard X, Debert $C$, et al. Incidence and characterization of MLL gene (11q23) rearrangements in acute myeloid leukemia M1 and M5. Blood 1996;83:2496-505.

5. Abeysinghe SS, Chuzhanova N, Krawczak M, Ball EV, Cooper DN Translocation and gross deletion breakpoints in human inherited disease and cancer I: Nucleotide composition and recombinationassociated motifs. Hum Mutat 2003;22:229-44.

6. Chuzhanova N, Abeysinghe SS, Krawczak M, Cooper DN. Translocation and gross deletion breakpoints in human inherited disease and cancer II: Potential involvement of repetitive sequence elements in secondary structure formation between DNA ends. Hum Mutat 2003:22:245-51.

7. Kohany O, Gentles AJ, Hankus L, Jurka J. Annotation, submission and screening of repetitive elements in Repbase: RepbaseSubmitter and Censor. BMC Bioinformatics 2006;25:474

8. Rasmussen SW. SEQtools version 8.4 - build 028 http://www.seqtools.dk 2007. 
MATERIAL AND METHODS, RESULTS AND DISCUSSION 


\section{PAPER \#4}

Joana Santos, Nuno Cerveira, Cecília Correia, Susana Lisboa, Manuela Pinheiro, Lurdes Torres, Susana Bizarro, Joana Vieira, Luísa Viterbo, José $M$. Mariz, Manuel R. Teixeira

\section{COEXISTENCE OF ALTERNATIVE MLL-SEPT9 FUSION} TRANSCRIPTS IN AN ACUTE MYELOID LEUKEMIA WITH $t(11 ; 17)(q 23 ; q 25)$

Cancer Genet Cytogenet, 197: 60-64, 2010 
MATERIAL AND METHODS, RESULTS AND DISCUSSION 


\title{
Coexistence of alternative $M L L-S E P T 9$ fusion transcripts in an acute myeloid leukemia with $\mathrm{t}(11 ; 17)(\mathrm{q} 23 ; \mathrm{q} 25)$
}

\author{
Joana Santos ${ }^{\mathrm{a}}$, Nuno Cerveira ${ }^{\mathrm{a}}$, Cecília Correia ${ }^{\mathrm{a}}$, Susana Lisboa ${ }^{\mathrm{a}}$, Manuela Pinheiro ${ }^{\mathrm{a}}$, \\ Lurdes Torres ${ }^{\mathrm{a}}$, Susana Bizarro ${ }^{\mathrm{a}}$, Joana Vieira ${ }^{\mathrm{a}}$, Luisa Viterbo ${ }^{\mathrm{b}}$, José M. Mariz ${ }^{\mathrm{b}}$, \\ Manuel R. Teixeira ${ }^{\mathrm{a}, \mathrm{c}, *}$ \\ ${ }^{a}$ Department of Genetics, Portuguese Oncology Institute, Rua Dr. António Bernardino de Almeida, 4200-072 Porto, Portugal \\ ${ }^{\mathrm{b}}$ Department of Hemato-Oncology, Portuguese Oncology Institute, Rua Dr. António Bernardino de Almeida, 4200-072 Porto, Portugal \\ cAbel Salazar Biomedical Sciences Institute (ICBAS), Largo Prof. Abel Salazar, 2, 4099-003 Porto, Portugal \\ Received 10 July 2009; received in revised form 17 October 2009; accepted 17 October 2009
}

\begin{abstract}
We present the characterization at the RNA level of an acute myeloid leukemia with a $\mathrm{t}(11 ; 17)(\mathrm{q} 23 ; \mathrm{q} 25)$ and a $M L L$ rearrangement demonstrated by FISH. Molecular analysis led to the identification of two coexistent in-frame $M L L-S E P T 9$ fusion transcripts (variants 1 and 2), presumably resulting from alternative splicing. Real-time quantitative RT-PCR analysis showed that the relative expression of the $M L L-S E P T 9$ fusion variant 2 was 1.88 fold higher than the relative expression of $M L L-S E P T 9$ fusion variant 1. This is the first description of a MLL-SEPT9 fusion resulting in coexistence of two alternative splicing variants, each of which previously found isolated in myeloid leukemias. (c) 2010 Elsevier Inc. All rights reserved.
\end{abstract}

\section{Introduction}

Abnormalities of $11 \mathrm{q} 23$, resulting in fusion of the $M L L$ gene with numerous translocation partners, are found in primary acute lymphoblastic leukemia (ALL) and acute myeloid leukemia (AML), as well as in secondary, topoisomerase II inhibitor-related leukemia [1]. To date, more than $50 M L L$ fusion partners have been identified [2]. Five of these partner genes (SEPT2, SEPT5, SEPT6, SEPT9, and $S E P T 11)$ fall within an evolutionarily conserved family of genes that code for septins, a family with 14 members identified to date [2-5]. Septins are GTP-binding proteins involved in several processes of cell division and cellular integrity [6].

SEPT9 has previously been cloned as a fusion partner of $M L L$ in AML with $\mathrm{t}(11 ; 17)(\mathrm{q} 23 ; \mathrm{q} 25)[7,8]$. To our knowledge, $M L L-S E P T 9$ fusion transcripts have so far been characterized at the molecular level in only nine patients with myeloid neoplasms [7-12]. The MLL-SEPT9 rearrangements previously reported involve fusions between $M L L$ exon 8 and $S E P T 9$ exon 3 (fusion transcript variant 1) (five cases), MLL exon 8 and SEPT9 exon 2 (fusion transcript

\footnotetext{
* Corresponding author. Tel.: +351-225084000; fax: +351-225084016 E-mail address: manuel.teixeira@ipoporto.min-saude.pt (M.R. Teixeira).
}

0165-4608/10/\$ - see front matter (C) 2010 Elsevier Inc. All rights reserved. doi:10.1016/j.cancergencyto.2009.10.010 variant 2) (two cases), and $M L L$ exon 7 and SEPT9 exon 2 (fusion transcript variant 3) (two cases), with each case presenting only one fusion transcript variant [7-12]. We here report qualitative and quantitative reverse transcriptasepolymerase chain reaction (RT-PCR) characterization of one AML patient with a $\mathrm{t}(11 ; 17)(\mathrm{q} 23 ; \mathrm{q} 25)$ and two coexistent, in-frame $M L L-S E P T 9$ fusion variants.

\section{Case report}

A previously healthy 31-year-old man was admitted to the Portuguese Oncology Institute (Porto, Portugal) in February 2009 because of fever, chest pain, and odynophagia. The patient presented with disseminated intravascular coagulation. Peripheral blood analysis revealed hyperleukocytosis $\left(114 \times 10^{9} / \mathrm{L}\right)$ and thrombocytopenia $(23 \times$ $109 / \mathrm{L}$ ), with $70 \%$ blasts. The bone marrow was hypercellular, with $79 \%$ blasts with the M1 French-AmericanBritish morphology. The induction protocol was the classical " $7+3$ " therapy regimen (cytarabine for 7 days and daunorubicin for 3 days), after which cytogenetic remission was achieved. Consolidation was performed according to the CALGB protocol with high-dose cytarabine. The patient has no evidence of disease at the time of 

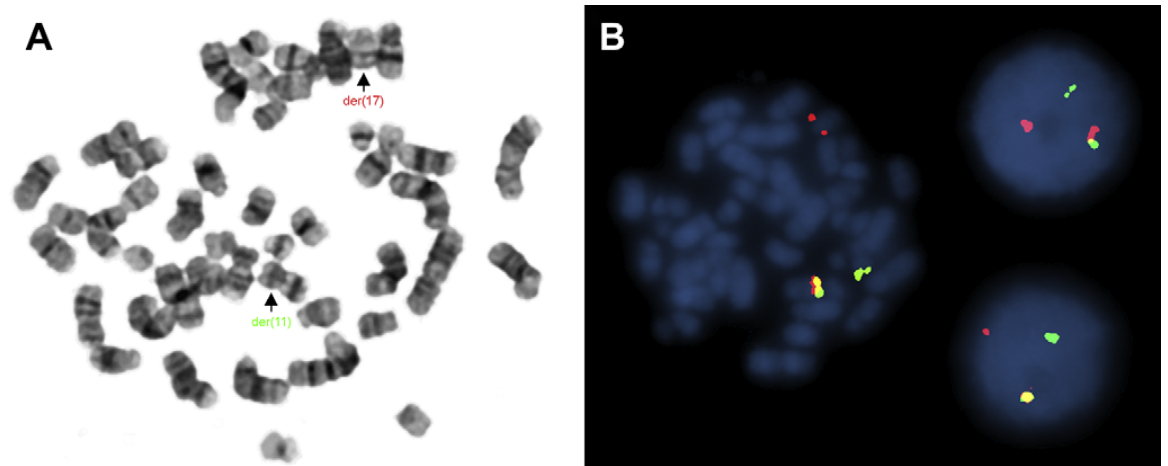

Fig. 1. Cytogenetic and fluorescence in situ hybridization (FISH) studies of the acute myeloid leukemia patient. (A) Giemsa-banded metaphase of bone marrow cells at diagnosis shows the presence of a $\mathrm{t}(11 ; 17)(\mathrm{q} 23 ; \mathrm{q} 25)$ rearrangement as the sole abnormality, suggesting the involvement of the $M L L$ gene located at 11q23. (B) FISH analysis with an MLL probe shows a split signal, confirming the break of the $M L L$ gene in the leukemic cells $\left(5^{\prime} M L L\right.$ green; $3^{\prime} M L L$ red).

writing and will be subjected to allogeneic bone marrow transplantation.

\section{Cytogenetics}

Conventional cytogenetics and molecular cytogenetic analysis was performed as previously described [3]. Chromosome banding analysis of the patient sample at diagnosis revealed the following karyotype: 46,XY,t $(11 ; 17)$ (q23;q25)[13]/46,XY[7] (Fig. 1A), suggesting a rearrangement of the MLL gene located in 11q23. Fluorescence in situ hybridization analysis of the $M L L$ locus in metaphases detected the typical split signal observed in $M L L$ rearranged neoplasms (Fig. 1B), showing the translocation of the $5^{\prime} M L L$ region to $17 \mathrm{q} 25$, where the $S E P T 9$ gene is located.

\section{Molecular studies}

To evaluate this hypothesis, total RNA was extracted from the patient's bone marrow sample using standard methods and cDNA was synthesized as previously described [3]. The RT-PCR assay for detection of $M L L-S E P T 9$ fusion transcripts was performed with a forward primer (MLL-S; 5'GAGGATCCTGCCCCAAAGAAAAG- $3^{\prime}$ ) located in $M L L$ exon 8 and a reverse primer (SEPT9-AS; 5'-CTGGAA TTTCTGGGTGGAGCT-3') located in SEPT9 exon 3. Additional primers in the $M L L$ breakpoint cluster region (exons 9 to 13) and SEPT9 open reading frame (exons 4 to 12) were used to exclude the presence of additional splice variants. To check the integrity of the mRNA sample we amplified a control gene $(B 2 M)$ with primers B2M-S (5'ATGTCTCGCTCCGTGGCCTTAGCT- $3^{\prime}$ ) and B2M-AS (5'-CCTCCATGATGCTGCTTACATGTC-3'). PCR amplification was performed according to a previously published protocol [3].

Agarose gel analysis of the RT-PCR products showed the presence of two PCR fragments: a larger fragment with
$438 \mathrm{bp}$ and a smaller fragment with $381 \mathrm{bp}$, suggesting the presence of two distinct $M L L-S E P T 9$ fusions (Fig. 2A). To confirm this hypothesis, gel band extraction and purification followed by sequencing analysis of both fragments revealed the presence of in-frame fusions of $M L L$ exon 8 with SEPT9 exon 3 (fusion variant 1) (Fig. 2B) and exon 2 (fusion variant 2) (Fig. 2C), respectively. No additional variants were found when other primer combinations were used. The presence of two MLL-SEPT9 PCR fragments with different intensities raised the possibility that they could be differentially expressed. Accordingly, RNA expression of the two MLL-SEPT9 fusion variants was determined by real-time quantitative PCR (RQ-PCR) on an ABI PRISM 7000 sequence detection system (Applied Biosystems, Foster City, CA). The primers (MLL-S1; 5'CCACTCCTAGTGAGCCCAAGA-3', SEPT9-AS1; 5'-TG GAGTTGGGTGTCTCGACC-3', and SEPT9-AS2; 5'-GG AGGTCCGCGTGCCT- $3^{\prime}$ ) and probe (MLL-PR; $5^{\prime}$-FAMAAGCAGCCTCCACCACCAGAATCA-TAMRA-3') were designed with Applied Biosystems Primer Express 2.0 and the $A B L 1$ gene was used as endogenous control. RQ-PCR was performed as previously described [13].

Relative expression levels of the target transcripts were calculated using the comparative cycle threshold $\left(C_{\mathrm{T}}\right)$ method as described by Schmittgen et al. [14]. The relative expression of the two splice variants, calculated using the $2^{-\Delta \Delta \mathrm{CT}}$ method as $\left[2^{-\Delta \Delta \mathrm{CT}} M L L-S E P T 9\right.$ (variant 2)/ $2^{-\triangle \Delta C T} M L L-S E P T 9$ (variant 1)], showed that the relative expression of the $M L L-S E P T 9$ variant 2 was 1.88 -fold higher than the $M L L-S E P T 9$ variant 1 (range, 1.78- to 1.99-fold).

\section{Discussion}

Rearrangements between 11q23 and 17q25 have previously been reported in myeloid neoplasms, but in only nine cases was molecular characterization of the fusion 


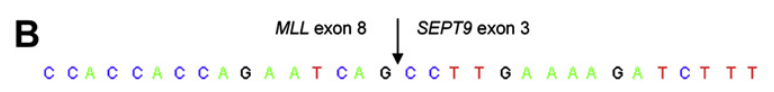

A
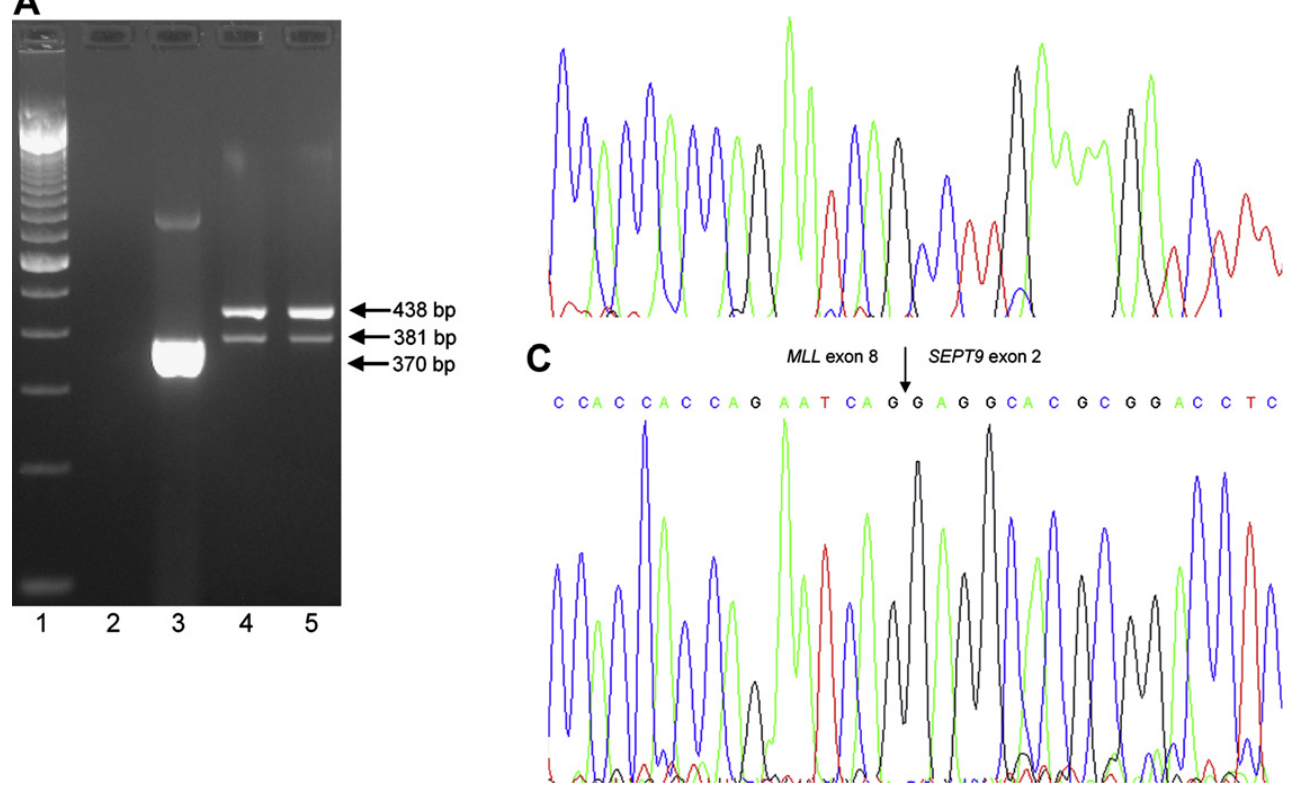

Fig. 2. Molecular characterization of the $M L L-S E P T 9$ fusion transcripts. (A) Reverse transcriptase-polymerase chain reaction (RT-PCR) analysis showing the presence of the $M L L-S E P T 9$ variant transcripts. Lanes 4 and 5: Detection of a larger (438 bp) and a smaller ( $381 \mathrm{bp})$ PCR fragment suggests the fusion of $M L L$ exon 8 with SEPT9 exons 2 and 3, respectively. Lane 3: RNA integrity check (B2 $M$ gene) shows clear amplification of the expected 370-bp RT-PCR fragment. Lane 2: negative control. Lane 1: 100-bp molecular marker. (B,C) Sequence analysis performed on the amplified RT-PCR product revealed two inframe fusions, between $M L L$ exon 8 and SEPT9 exon 3 (fusion transcript variant 1) (B) and between $M L L$ exon 8 and SEPT9 exon 2 (fusion transcript variant 2) (C).

transcript performed [7-12]. Three different $M L L-S E P T 9$ in-frame variants were described with each case presenting only one fusion transcript variant [7-12]. We describe the case of an AML patient with the simultaneous presence of two different types of $M L L-S E P T 9$ chimeric transcripts, corresponding to the fusion between $M L L$ exon 8 and SEPT9 exons 3 (fusion variant 1) or 2 (fusion variant 2). To our knowledge, this is the first reported case of $M L L-$ SEPT9 with coexistence of two transcript variants. This phenomenon has previously been described also in $M L L-S E P T 6$ AML patients [15], but not in those with $M L L-S E P T 2, M L L-S E P T 5$, or $M L L-S E P T 11$ fusions [3,16-19].

Because there is no cytogenetic evidence of two translocations (Fig. 1), the most likely explanation for the coexistent fusion transcript variants is alternative splicing of a single gene fusion with breakpoints in $M L L$ intron 7 and SEPT9 intron 1 . The detection of coexistent $M L L-$ SEPT variants is facilitated by the use of one-step RTPCR methodology with specific primers, which has been shown to be more specific and sensitive than classic RTPCR with cDNA synthesis with random primers and subsequent RT-PCR analysis [20] used in previous $M L L-S E P T 9$ studies [7-12]. Nevertheless, our quantitative transcript analysis showed that both fusion variants are produced at significant levels, with the relative expression of variant 2 being approximately twofold higher than that of variant 1 .

The alternative splicing observed in our patient affects the SEPT9 gene (exon 2 or 3 ) but not the MLL gene (exon 8 ), in contrast to our previous observation in $M L L-S E P T 6$ rearrangements, in which the alternative splicing always affected the fused $M L L$ gene and not the SEPT6 gene [15]. The mechanisms underlying this variation are unknown, but splicing of wild-type SEPT9 seems to be a very frequent event, with 18 different SEPT9 splicing isoforms described to date. The functional significance of the various $M L L-S E P T 9$ and wild-type SEPT9 isoforms remains to be elucidated [21,22].

SEPT9 belongs to an evolutionarily conserved family of genes that encode a GTP-binding domain flanked by a polybasic domain and, with the exception of SEPT9, a coiledcoil region [6]. In previously characterized $M L L-S E P T 9$ fusion patients, almost the entire open reading frame of the SEPT9 protein, containing all the septin functional domains, is fused with the N-terminal moiety of MLL [7-12]. This was also the case of our patient, where the $\mathrm{C}$ terminus of the fusion products contains all but the first 5 (variant 1) or 24 (variant 2) amino acids of SEPT9. This 


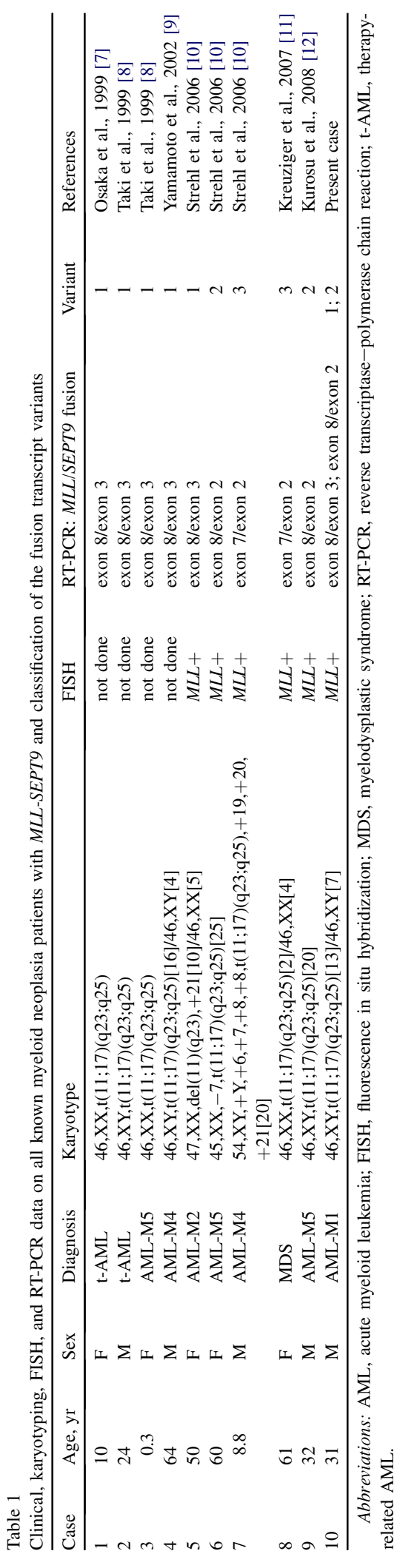

seems to be the rule in the case of $M L L-S E P T$ fusions. Indeed, in all the reported $M L L-$ septin fusions the breakpoints are found at the very $5^{\prime}$ end of known septin open reading frames $[3,7-12,15-19]$. In addition, the $5^{\prime} M L L$ region of the $M L L-S E P T 9$ fusion protein retains in all cases the LEDGF-menin binding motif and the CxxC domain, both of which are necessary for $M L L$ fusion transformation [23,24]. Little is known about the function of SEPT9 in normal cell biology and tumorigenesis [25,26], but its expression is downregulated in head and neck squamous cell carcinoma [27], and several SEPT9 splicing variants are overexpressed in breast, ovarian, and prostate cancer [28-31].

All cases reported with the $M L L-S E P T 9$ rearrangement are myeloid neoplasm patients (eight AML and one MDS), with an age range from 4 months to 61 years (Table 1). This suggests that the $M L L-S E P T 9$ fusion is preferentially associated with myeloid leukemogenesis, as also seems to be the case of $M L L$ fusions with other septins (SEPT2, SEPT5, SEPT6, and SEPT11) [3,15-19]. Let alone its biological and functional significance, the clinical value of the detection of two $M L L-S E P T 9$ variants originated by alternative splicing is not known. The outcome of $M L L-S E P T 9$ patients seems to be poor, regardless of the fusion variant detected [12]. However, further studies of larger series of AML patients with the $M L L-S E P T 9$ fusion gene will be necessary to answer this question.

\section{Acknowledgments}

This research was supported by grants from the Portuguese Association Against Leukemia (Associação Portuguesa Contra a Leucemia; 2006-30.2.AP/MJ) and the Commission for the Promotion of Research in Health Care (Comissão de Fomento da Investigação em Cuidados de Saúde; P.I. 26/2007).

\section{References}

[1] Rowley JD. Chromosome translocations: dangerous liaisons revisited. Nat Rev Cancer 2001;1:245-50.

[2] Meyer C, Kowarz E, Hofmann J, Renneville A, Zuna J, Trka J, Ben Abdelali R, Macintyre E, De Braekeleer E, De Braekeleer M, Delabesse E, de Oliveira MP, Cavé H, Clappier E, van Dongen JJ, Balgobind BV, van den Heuvel-Eibrink MM, Beverloo HB, PanzerGrümayer R, Teigler-Schlegel A, Harbott J, Kjeldsen E, Schnittger S, Koehl U, Gruhn B, Heidenreich O, Chan LC, Yip SF, Krzywinski M, Eckert C, Möricke A, Schrappe M, Alonso CN, Schäfer BW, Krauter J, Lee DA, Zur Stadt U, Te Kronnie G, Sutton R, Izraeli S, Trakhtenbrot L, Lo Nigro L, Tsaur G, Fechina L, Szczepanski T, Strehl S, Ilencikova D, Molkentin M, Burmeister T, Dingermann T, Klingebiel T, Marschalek R. New insights to the $M L L$ recombinome of acute leukemias. Leukemia 2009;23:1490-9.

[3] Cerveira N, Correia C, Bizarro S, Pinto C, Lisboa S, Mariz JM, Marques M, Teixeira MR. SEPT2 is a new fusion partner of $M L L$ in acute myeloid leukemia with $\mathrm{t}(2 ; 11)(\mathrm{q} 37 ; \mathrm{q} 23)$. Oncogene 2006; 25:6147-52. 
[4] Hall PA, Jung K, Hillan KJ, Russell SE. Expression profiling the human septin gene family. J Pathol 2005;206:269-78.

[5] Peterson EA, Kalikin LM, Steels JD, Estey MP, Trimble WS, Petty EM. Characterization of a SEPT9 interacting protein, SEPT14, a novel testis-specific septin. Mamm Genome 2007;18:796-807.

[6] Hall PA, Russell SE. The pathobiology of the septin gene family. J Pathol 2004;204:489-505.

[7] Osaka M, Rowley JD, Zeleznik-Le NJ. MSF (MLL septin-like fusion), a fusion partner gene of $M L L$, in a therapy-related acute myeloid leukemia with a t(11;17)(q23;q25). Proc Natl Acad Sci U S A 1999;96:6428-33.

[8] Taki T, Ohnishi H, Shinohara K, Sako M, Bessho F, Yanagisawa M, Hayashi Y. AF17q25, a putative septin family gene, fuses the $M L L$ gene in acute myeloid leukemia with $\mathrm{t}(11 ; 17)(\mathrm{q} 23 ; \mathrm{q} 25)$. Cancer Res 1999;59:4261-5.

[9] Yamamoto K, Shibata F, Yamaguchi M, Miura O. Fusion of $M L L$ and $M S F$ in adult de novo acute myelomonocytic leukemia (M4) with $\mathrm{t}(11 ; 17)(\mathrm{q} 23 ; \mathrm{q} 25)$. Int J Hematol 2002;75:503-7.

[10] Strehl S, König M, Meyer C, Schneider B, Harbott J, Jäger U, von Bergh AR, Loncarevic IF, Jarosova M, Schmidt HH, Moore SD, Marschalek R, Haas OA. Molecular dissection of $\mathrm{t}(11 ; 17)$ in acute myeloid leukemia reveals a variety of gene fusions with heterogeneous fusion transcripts and multiple splice variants. Genes Chromosomes Cancer 2006;45:1041-9.

[11] Kreuziger LMB, Porcher JC, Ketterling RP, Steensma DP. An $M L L-S E P T 9$ fusion and $\mathrm{t}(11 ; 17)(\mathrm{q} 23 ; \mathrm{q} 25)$ associated with de novo myelodysplastic syndrome. Leuk Res 2007;31:1145-8.

[12] Kurosu T, Tsuji K, Ohki M, Miki T, Yamamoto M, Kakihana K, Koyama T, Taniguchi S, Miura O. A variant-type $M L L / S E P T 9$ fusion transcript in adult de novo acute monocytic leukemia (M5b) with $\mathrm{t}(11 ; 17)(\mathrm{q} 23 ; \mathrm{q} 25)$. Int J Hematol 2008;88:192-6.

[13] Cerveira N, Santos J, Bizarro S, Costa V, Ribeiro FR, Lisboa S, Correia C, Torres L, Vieira J, Snijder S, Mariz JM, Norton L, Mellink CH, Buijs A, Teixeira MR. Both SEPT2 and MLL are down-regulated in $M L L-S E P T 2$ therapy-related myeloid neoplasia. BMC Cancer 2009;9:147.

[14] Schmittgen TD, Lee EJ, Jiang J, Sarkar A, Yang L, Elton TS, Chen C Real-time PCR quantification of precursor and mature microRNA. Methods 2008;44:31-8.

[15] Cerveira N, Micci F, Santos J, Pinheiro M, Correia C, Lisboa S, Bizarro S, Norton L, Heim S, Teixeira MR. Molecular characterization of the $M L L-S E P T 6$ fusion gene in acute myeloid leukemia: identification of novel fusion transcripts and cloning of genomic breakpoint junctions. Haematologica 2008;93:1076-80.

[16] Cerveira N, Santos S, Pinheiro M, Snijder S. H van der Lelie, Mellink $\mathrm{CH}$, Teixeira MR. A novel $M L L-S E P T 2$ fusion variant in therapy-related myelodysplastic syndrome. Cancer Genet Cytogenet 2008;185:62-4.

[17] Megonigal MD, Rappaport EF, Jones DH, Williams TM, Lovett BD, Kelly KM, Lerou PH, Moulton T, Budarf ML, Felix CA. t(11; 22)(q23;q11.2) in acute myeloid leukemia of infant twins fuses $M L L$ with $h C D C r e l$, a cell division cycle gene in the genomic region of deletion in DiGeorge and velocardiofacial syndromes. Proc Natl Acad Sci U S A 1998;95:6413-8.
[18] Tatsumi K, Taki T, Taniwaki M, Nakamura H, Taguchi J, Chen YZ, Bessho F, Yanagisawa M, Hayashi Y. The CDCREL1 gene fused to $M L L$ in de novo acute myeloid leukemia with $\mathrm{t}(11 ; 22)(\mathrm{q} 23 ; \mathrm{q} 11.2)$ and its frequent expression in myeloid leukemia cell lines. Genes Chromosomes Cancer 2001;30:230-5.

[19] Kojima K, Sakai I, Hasegawa A, Niiya H, Azuma T, Matsuo Y, Fujii N, Tanimoto M, Fujita S. FLJ10849, a septin family gene, fuses MLL in a novel leukemia cell line CNLBC1 derived from chronic neutrophilic leukemia in transformation with $\mathrm{t}(4 ; 11)(\mathrm{q} 21 ; \mathrm{q} 23)$. Leukemia 2004;18:998-1005.

[20] Cerveira N, Torres L, Rocha P, Bizarro S, Pereira D, Abreu J, Henrique R, Teixeira MR, Castedo S. Highly sensitive detection of the $M G B 1$ transcript (mammaglobin) in the peripheral blood of breast cancer patients. Int J Cancer 2004;108:592-5.

[21] Russell SE, Hall PA. Do septins have a role in cancer? Br J Cancer 2005;93:499-503.

[22] McIlhatton MA, Burrows JF, Donaghy PG, Chanduloy S, Johnston PG, Russell SE. Genomic organization, complex splicing pattern and expression of a human septin gene on chromosome 17q25.3. Oncogene 2001;20:5930-9.

[23] Yokoyama A, Somervaille TC, Smith KS, Rozenblatt-Rosen O, Meyerson M, Cleary ML. The menin tumor suppressor protein is an essential oncogenic cofactor for $M L L$-associated leukemogenesis. Cell 2005;123:207-18.

[24] Ayton PM, Chen EH, Cleary ML. Binding to nonmethylated CpG DNA is essential for target recognition, transactivation, and myeloid transformation by an MLL oncoprotein. Mol Cell Biol 2004;24:10470-8.

[25] Amir S, Wang R, Matzkin H, Simons JW, Mabjeesh NJ. MSF-A interacts with hypoxia-inducible factor- $1 \alpha$ and augments hypoxiainducible factor transcriptional activation to affect tumorigenicity and angiogenesis. Cancer Res 2006;66:856-66.

[26] Gonzalez ME, Makarova O, Peterson EA, Privette LM, Petty EM. Up-regulation of SEPT9_v1 stabilizes c-Jun-N-terminal kinase and contributes to its pro-proliferative activity in mammary epithelial cells. Cell Signal 2009;21:477-87.

[27] Bennett KL, Karpenko M, Lin MT, Claus R, Arab K, Dyckhoff G Plinkert P, Herpel E, Smiraglia D, Plass C. Frequently methylated tumor suppressor genes in head and neck squamous cell carcinoma. Cancer Res 2008;68:4494-9.

[28] Burrows JF, Chanduloy S, McIlhatton MA, Nagar H, Yeates K, Donaghy P, Price J, Godwin AK, Johnston PG, Russell SE. Altered expression of the septin gene, SEPT9, in ovarian neoplasia. J Pathol 2003;201:581-8.

[29] Scott M, Hyland PL, McGregor G, Hillan KJ, Russell SE, Hall PA. Multimodality expression profiling shows SEPT9 to be overexpressed in a wide range of human tumours. Oncogene 2005;24:4688-700.

[30] Scott M, McCluggage WG, Hillan KJ, Hall PA, Russell SE. Altered patterns of transcription of the septin gene, SEPT9, in ovarian tumorigenesis. Int J Cancer 2006;118:1325-9.

[31] Gonzalez ME, Peterson EA, Privette LM, Loffreda-Wren JL, Kalikin LM, Petty EM. High SEPT9_v1 expression in human breast cancer cells is associated with oncogenic phenotypes. Cancer Res 2007;67:8554-64. 
MATERIAL AND METHODS, RESULTS AND DISCUSSION 
MATERIAL AND METHODS, RESULTS AND DISCUSSION

2. Septin gene expression changes in myeloid neoplasia 
MATERIAL AND METHODS, RESULTS AND DISCUSSION 


\section{PAPER \#5}

Nuno Cerveira, Joana Santos, Susana Bizarro, Franclim R. Ribeiro, Susana Lisboa, Cecília Correia, Lurdes Torres, Joana Vieira, Simone Snijder, José $M$. Mariz, Lucília Norton, Hans van der Lelie, Clemens H Mellink, Arjan Buijs, Manuel R. Teixeira

BOTH SEPT2 AND MLL ARE DOWN-REGULATED IN MLL-SEPT2 THERAPY-RELATED MYELOID NEOPLASIA

BMC Cancer, 9: 147, 2009 
MATERIAL AND METHODS, RESULTS AND DISCUSSION 


\author{
Both SEPT2 and MLL are down-regulated in MLL-SEPT2 \\ therapy-related myeloid neoplasia \\ Nuno Cerveira ${ }^{1}$, Joana Santos ${ }^{1}$, Susana Bizarro ${ }^{1}$, Vera Costa ${ }^{1}$, \\ Franclim R Ribeiro ${ }^{1}$, Susana Lisboa ${ }^{1}$, Cecília Correia ${ }^{1}$, Lurdes Torres ${ }^{1}$, \\ Joana Vieira ${ }^{1}$, Simone Snijder ${ }^{2}$, José M Mariz ${ }^{3}$, Lucília Norton ${ }^{4}$, \\ Clemens H Mellink2 ${ }^{2}$, Arjan Buijs ${ }^{5}$ and Manuel R Teixeira*1,6
}

\begin{abstract}
Address: ${ }^{1}$ Department of Genetics, Portuguese Oncology Institute, Porto, Portugal, ${ }^{2}$ Department of Clinical Genetics, Academic Medical Center, Amsterdam, The Netherlands, ${ }^{3}$ Department of Hemato-Oncology, Portuguese Oncology Institute, Porto, Portugal, ${ }^{4}$ Department of Pediatrics, Portuguese Oncology Institute, Porto, Portugal, ${ }^{5}$ Department of Medical Genetics, University Medical Center, Utrecht, The Netherlands and ${ }^{6} \mathrm{Abel}$ Salazar Biomedical Sciences Institute (ICBAS), Porto, Portugal

Email: Nuno Cerveira - nscerveira@gmail.com; Joana Santos - joana.cris.santos@gmail.com; Susana Bizarro - susanabizarro@gmail.com; Vera Costa - veralmcosta@gmail.com; Franclim R Ribeiro - ribeirofr@gmail.com; Susana Lisboa - susanalisboa@hotmail.com; Cecília Correia - correia.cecilia@gmail.com; Lurdes Torres - lurdes_torres@hotmail.com; Joana Vieira - joana_vieira@netcabo.pt; Simone Snijder - s.snijder@amc.uva.nl; José M Mariz - mariz@ipoporto.min-saude.pt; Lucília Norton - lucilia.norton@ipoporto.min-saude.pt; Clemens H Mellink - c.h.mellink@amc.uva.nl; Arjan Buijs - a.buijs@umcutrecht.nl; Manuel R Teixeira* - manuel.teixeira@ipoporto.minsaude.pt

* Corresponding author
\end{abstract}

Published: 15 May 2009

BMC Cancer 2009, 9:147 doi:10.1 |86/I47|-2407-9-147

This article is available from: http://www.biomedcentral.com/I47/-2407/9//47

(C) 2009 Cerveira et al; licensee BioMed Central Ltd.

This is an Open Access article distributed under the terms of the Creative Commons Attribution License (http://creativecommons.org/licenses/by/2.0), which permits unrestricted use, distribution, and reproduction in any medium, provided the original work is properly cited.
Received: 3 December 2008

Accepted: 15 May 2009

\begin{abstract}
Background: A relevant role of septins in leukemogenesis has been uncovered by their involvement as fusion partners in MLL-related leukemia. Recently, we have established the MLL-SEPT2 gene fusion as the molecular abnormality subjacent to the translocation $\mathrm{t}(2 ; 1 \mathrm{I})(\mathrm{q} 37 ; \mathrm{q} 23)$ in therapy-related acute myeloid leukemia. In this work we quantified MLL and SEPT2 gene expression in 58 acute myeloid leukemia patients selected to represent the major AML genetic subgroups, as well as in all three cases of MLL-SEPT2-associated myeloid neoplasms so far described in the literature.
\end{abstract}

Methods: Cytogenetics, fluorescence in situ hybridization (FISH) and molecular studies (RT-PCR, qRT-PCR and qMSP) were used to characterize 58 acute myeloid leukemia patients (AML) at diagnosis selected to represent the major AML genetic subgroups: CBFB-MYHII $(\mathrm{n}=13)$, PML-RARA $(\mathrm{n}=12) ; R U N X I-R U N X I T I(\mathrm{n}=\mid 2)$, normal karyotype $(\mathrm{n}=\mathrm{II})$, and MLL gene fusions other than MLL-SEPT2 $(\mathrm{n}=10)$. We also studied all three MLL-SEPT2 myeloid neoplasia cases reported in the literature, namely two AML patients and a t-MDS patient.

Results: When compared with normal controls, we found a 12.8-fold reduction of wild-type SEPT2 and MLLSEPT2 combined expression in cases with the MLL-SEPT2 gene fusion $(p=0.007)$, which is accompanied by a $12.4-$ fold down-regulation of wild-type MLL and MLL-SEPT2 combined expression $(p=0.028)$. The down-regulation of SEPT2 in MLL-SEPT2 myeloid neoplasias was statistically significant when compared with all other leukemia genetic subgroups (including those with other MLL gene fusions). In addition, MLL expression was also down-regulated in the group of MLL fusions other than MLL-SEPT2, when compared with the normal control group $(p=0.023)$

Conclusion: We found a significant down-regulation of both SEPT2 and MLL in MLL-SEPT2 myeloid neoplasias. In addition, we also found that MLL is under-expressed in AML patients with MLL fusions other than MLL-SEPT2. 


\section{Background}

Septins comprise an evolutionarily conserved family of GTP-binding proteins that are found primarily in fungi and animals [1]. In humans, 14 septin genes have been characterized to date (SEPT1 to SEPT14). All septin transcripts contain multiple translation initiation sites and are alternatively spliced, giving origin to multiple septin isoforms, some of which are tissue specific [1]. Although the precise functions of septins remain unclear, current data suggest that they coordinate changes in cytoskeletal and membrane organization by acting as scaffolds that recruit factors to precise sites in a cell and/or as barriers that segregate membrane areas into discrete domains $[1,2]$. For instance, the human SEPT2 associates with SEPT6 and SEPT7 to form an hexamer complex that is the core unit for generation of septin filaments associated with the contractile ring in dividing cells, being therefore essential for proper cytokinesis and chromosome segregation $[2,3]$.

Septins have been reported to be deregulated in various human diseases, including cancer [4]. A relevant role of septins in leukemogenesis has been uncovered by their involvement as fusion partners in $M L L$-related leukemia. We have established the MLL-SEPT2 gene fusion as the molecular abnormality subjacent to the translocation $\mathrm{t}(2 ; 11)(\mathrm{q} 37 ; \mathrm{q} 23)$ in therapy-related acute myeloid leukemia (t-AML) [5]. Subsequently, van Binsbergen et al [6] identified a second MLL-SEPT2 fusion variant in a patient with t-AML and we have recently uncovered a third MLLSEPT2 alternative fusion variant in a case of therapyrelated myelodysplastic syndrome (t-MDS) $[7,8]$. Four other septin family genes (SEPT5, SEPT6, SEPT9 and SEPT11) had previously been identified as MLL fusion partners in leukemia, making the septins the protein family with more numbers involved in $M L L$-related leukemia [9-13], and suggesting that their involvement in leukemogenesis is not a chance event. This hypothesis is supported by the fact that all the reported $M L L$-septin fusions are in frame and the breakpoints are found at the very 5 ' end of known septin open reading frames [5,9-13]. In this work we show evidence that the fusion of MLL with SEPT2 is associated with down-regulation of both SEPT2 and MLL expression in $\mathrm{t}-\mathrm{AML} / \mathrm{t}-\mathrm{MDS}$.

\section{Methods}

\section{Patient samples}

We studied 58 acute myeloid leukemia patients (AML) at diagnosis selected to represent the major AML genetic subgroups, including 13 cases with a CBFB-MYH11 rearrangement, 12 cases with a PML-RARA rearrangement, 12 cases with a RUNX1-RUNX1T1 rearrangement, 11 cases with normal karyotype, and 10 cases with rearrangements of the MLL gene other than MLL-SEPT2 [see Additional file 1]. We also studied all three MLL-SEPT2 patients reported in the literature, namely two with t-AML (patients 59 and 60 ) and the third with t-MDS (patient 61), which were the primary targets of our investigation [see Additional file 1] [5-8]. All but patients 60 and 61 were treated at the Portuguese Oncology Institute, Porto, Portugal, and bone marrow samples were obtained to perform cytogenetic and molecular studies. Patients 60 and 61 were treated in the Netherlands at the St. Antonius Hospital, Nieuwegein [6] and the Amsterdam Academic Medical Center [7], respectively, from whom cDNA was obtained.

As a control group we studied bone marrow samples obtained from ten individuals studied for the purpose to rule out a hematological disease.

This study was approved by the Portuguese Oncology Institute ethic committee, and informed consent was obtained from all patients.

\section{Chromosome banding and molecular cytogenetics}

The diagnostic bone marrow samples of the Portuguese patients (cases 1 to 59) were cultured for 24 hours in RPMI 1640 medium with GlutaMAX-I (Invitrogen, London, UK) supplemented with $20 \%$ fetal bovine serum (Invitrogen, London, UK). Chromosome preparations were made by standard methods and banded by trypsinLeishman. Karyotypes were described according to the International System for Human Cytogenetic Nomenclature [14].

Whenever appropriate, fluorescence in situ hybridization (FISH) analysis for specific fusion genes or rearrangements was performed using dual-color, break-apart or dual-fusion, probes (Vysis, Downers Grove, USA).

Chromosome banding and molecular cytogenetic analyses of patients 60 and 61 were described previously $[6,7]$.

\section{RNA extraction and CDNA synthesis}

Total RNA was extracted from the diagnostic bone marrow sample of patients 1 to 59 and controls using $1 \mathrm{ml}$ of Tripure isolation reagent (Roche Diagnostics, Indianapolis, USA) and quantified in a NanoDrop ND-100 spectrophotometer (NanoDrop Technologies, Wilmington, USA). For cDNA synthesis, $1 \mu \mathrm{g}$ of total RNA was subjected to reverse transcription with random hexamers using the Superscript III First-Strand Synthesis System for RT-PCR (Invitrogen, Carlsbad, USA), according to the manufacturer's instructions. The final cDNA was diluted with $30 \mu \mathrm{l}$ of $\mathrm{H}_{2} \mathrm{O}$. cDNA quantity and quality were assessed in a NanoDrop ND-100 spectrophotometer (NanoDrop Technologies, Wilmington, USA).

\section{Qualitative Reverse-Transcription Polymerase Chain Reaction (RT-PCR)}

RT-PCR assays for detection of the fusion transcripts RUNX1-RUNX1T1, CBFB-MYH11, and PML-RARA were performed on the diagnostic samples according to the 
BIOMED-1 protocol [15]. The primers and PCR reaction conditions for the detection of rearrangements involving the $M L L$ gene were previously published $[5,10,16-19]$.

\section{Quantitative Real-Time Polymerase Chain Reaction (qRT- PCR)}

We have evaluated the mRNA expression of MLL and SEPT2 genes by qRT-PCR on an ABI PRISM 7000 Sequence Detection System (Applied Biosystems, Foster City, USA). Primers and probes for MLL and SEPT2 were derived from the published mRNA sequences of SEPT2 and MLL (GenBank accession nos. NM 001008491.1 and NM 005933.2, respectively), and designed with Primer Express 2.0 (Applied BioSystems) and purchased from Metabion (Metabion, Martinsried, Deutschland) [see Additional file 2]. Primers and probes for the ABL1 gene (GenBank accession no. NM 005157), used as endogenous control, were previously described and approved for qRT-PCR based diagnosis and minimal residual disease detection in leukaemic patients, due to be similarly expressed in normal and diagnostic samples as well as within normal samples [see Additional file 2] [20,21]. All primers and probes were designed outside of MLL and SEPT2 breakpoint cluster regions in exons $4-5$ and exons $3-4$, respectively. To determine the relative expression levels of the target gene in each sample, the relative amount of the target gene was calibrated to the relative amount of the internal reference gene and expressed in terms of ratios between the target and the reference that were then multiplied by 100 for easier tabulation (target gene/ABL1 $\times 100$ ). PCR reactions were performed in a $25 \mu \mathrm{l}$ volume containing $5 \mu \mathrm{l}$ of synthesized cDNA, $12.5 \mu \mathrm{l}$ of TaqMan universal PCR master mix, $0.3 \mu \mathrm{M}$ of each primer and 0.2 $\mu \mathrm{M}$ of each probe. PCR was performed in separate wells for each primer/probe set and each sample was run in triplicate. PCR parameters were as follows: $50^{\circ} \mathrm{C}$ for $2 \mathrm{~min}$., $95^{\circ} \mathrm{C}$ for $10 \mathrm{~min}$., followed by 50 cycles at $95^{\circ} \mathrm{C}$ for $15 \mathrm{~s}$. and $60^{\circ} \mathrm{C}$ for $1 \mathrm{~min}$. Each plate included non-template controls and serial dilutions of a strongly expressing sample (MLL or SEPT2) to construct the standard curves.

\section{Bisulfite treatment}

Sodium bisulfite conversion of unmethylated (but not methylated) cytosine residues to uracil in a sample of genomic DNA obtained from MLL-SEPT2 case 59 (DNA from MLL-SEPT2 cases 60 and 61 was not available) and three normal controls was performed as previously described [22]. Briefly, 500 ng of genomic DNA was denatured with $0.3 \mathrm{M} \mathrm{NaOH}$ in a total volume of $21 \mu \mathrm{l}$ for 20 min. at $50^{\circ} \mathrm{C}$. A volume of $450 \mu \mathrm{l}$ freshly prepared bisulfite solution (2.5 M sodium bisulfite, $125 \mathrm{mM}$ hydroquinone, and $0.2 \mathrm{M} \mathrm{NaOH}$ ) was added to each denaturation reaction, and the mixture was incubated at $70^{\circ} \mathrm{C}$ for 3 hours in the dark. The resulting bisulfite-converted DNA was then purified by using Wizard DNA purification resin
(Wizard DNA Clean-Up System; Promega, Madison, USA) according to the manufacturer's instructions and eluted in $45 \mu \mathrm{l}$ of water preheated at $70^{\circ} \mathrm{C}$. The eluted DNA was denatured in $0.3 \mathrm{M} \mathrm{NaOH}$ for $10 \mathrm{~min}$. at room temperature. Finally, the bisulfite converted and denatured genomic DNA was precipitated with $100 \%$ ethanol, dried, resuspended in $30 \mu \mathrm{l}$ of water, and stored at $-20^{\circ} \mathrm{C}$.

\section{Quantitative Methylation-Specific Polymerase Chain \\ Reaction (qMSP)}

Due to the very low quantity of DNA available from $M L L$ SEPT2 case 59 , only the SEPT2 gene could be analyzed by qMSP. The SEPT2 5'-CpG island was identified using the CpG Island Searcher http://cpgislands.com[23] and the SEPT2 genomic sequence (GenBank accession no. NT 005416.12). That CpG island was found to encompass the predicted SEPT2 promoter region using PROSCAN 1.7 [24]. Primers and probe for the SEPT2 5'-CpG island were designed with Methyl Primer Express 1.0 (Applied BioSystems, Foster City, USA), and selected to specifically amplify fully methylated bisulfite-converted DNA [see Additional file 2]. Primers and probe for the internal reference gene, АCTB (GenBank accession no. NM 001101), were described previously [25] and were designed to amplify and detect a region of the gene that is devoid of CpG nucleotides to normalize for DNA input in each sample [see Additional file 2]. qMSP of the chemically modified DNA was performed in an ABI PRISM 7000 Sequence Detection System (Applied Biosystems, Foster City, USA), as previously described [26]. In brief, fluorescence based real-time PCR assays were carried out in a reaction volume of $20 \mu \mathrm{L}$, consisting of $16.6 \mathrm{mM}$ ammonium sulfate, $67 \mathrm{mM}$ trizma preset, $6.7 \mathrm{mM} \mathrm{MgCl}{ }_{2}, 10$ $\mathrm{mM}$ mercaptoethanol, $0.1 \% \mathrm{DMSO}, 200 \mu \mathrm{M}$ each of dATP, dCTP, dGTP, and dTTP, $600 \mathrm{nM}$ of each primer, 0.4 $\mu \mathrm{L}$ of Rox dye, $200 \mathrm{nM}$ of probe, 1 unit of platinum Taq polymerase (Invitrogen, Carlsbad, USA), and $2 \mu \mathrm{l}$ of bisulfite-modified DNA as a template. PCR was performed in separate wells for each primer/probe set and each sample was run in triplicate. PCR was performed under the following conditions: $95^{\circ} \mathrm{C}$ for $2 \mathrm{~min}$., followed by 45 cycles of $95^{\circ} \mathrm{C}$ for $15 \mathrm{~s}$. and $60^{\circ} \mathrm{C}$ for $1 \mathrm{~min}$

To ensure the specificity of the analysis, each 96-well PCR plate had wells that contained completely methylated DNA at all CpGs (positive control - CpGenome Universal Methylated DNA, Chemicon Europe, Hampshire, UK), a completely unmethylated DNA (negative control - CpGenome Universal Unmethylated DNA, Chemicon Europe, Hampshire, UK), and multiple water blanks (contamination control). To determine the relative levels of methylated promoter DNA in each sample, we used serial dilutions of the positive control DNA to construct the calibration curve. The values obtained (mean quantity) for each target gene were divided by the respective values of 
the internal reference gene $(A C T B)$. The ratio thus generated, which constitutes an index of the percentage of input copies of DNA that are fully methylated at the primer- and probe-binding sites, was then multiplied by 100 for easier tabulation (methylation level $=$ target gene/reference gene $\times 100)$.

\section{Statistical analyses}

Normalized expression values for MLL and SEPT2 were compared among the different sample groups using the non-parametric Kruskal-Wallis $\mathrm{H}$ and Mann-Whitney U tests. The correlation between MLL and SEPT2 expression values within each group was assessed using Pearson's test. All analyses were performed using SPSS version 15.0 (SPSS, Chicago, USA).

\section{Results}

In all cases, RNA and/or cDNA quantity and quality was evaluated and was found to be appropriate for expression studies. The 260/280 and 260/230 absorbance ratios for RNA samples were in the range of 1.8-2.2. For the cDNA samples, the $260 / 280$ and $260 / 230$ sample absorbance ratios were in the range of $1.6-2.0$ and $1.8-2.2$, respectively.

Normalized expression levels for MLL and SEPT2 within each sample group are depicted in Figure 1. Statistically significant differences were observed for the combined wild-type SEPT2 and MLL-SEPT2 expression in the MLLSEPT2 cases when compared with the normal controls, showing a 12.8-fold lower median expression in the $M L L$ SEPT2 subset $(\mathrm{p}=0.007)$. Furthermore, the combined wild-type SEPT2 and MLL-SEPT2 expression was significantly lower (5.4 to 9.4 fold) in the MLL-SEPT2 cases than in all other leukemia genetic subgroups (Table 1). The combined expression of wild-type MLL and MLL-SEPT2 was also significantly lower $(12.4$ fold; $\mathrm{p}=0.028)$ in the MLL-SEPT2 myeloid neoplasias when compared with the normal controls, as well as with the CBFB-MYH11 and RUNX1-RUNX1T1 leukemia subgroups (13.4 and 10.5 fold, respectively). We next investigated whether DNA hypermethylation of the 5' SEPT2 region was contributing to the SEPT2 gene down-regulation, by examining the methylation status of the CpG island located upstream of the SEPT2 gene transcriptional initiation site [2225 base pair (bp) in length (-7457 to -9257)]. SEPT2 5' CpG island hypermethylation was detected in the positive control, but not in the MLL-SEPT2 case 59 or the normal controls.

No statistically significant differences were observed for the wild-type SEPT2 expression between the non-MLLSEPT2 leukemia subgroups and the normal controls, with the exception of the PML-RARA and "normal karyotype" leukemias that showed lower expression (Table 1). No statistically significant differences were observed for the
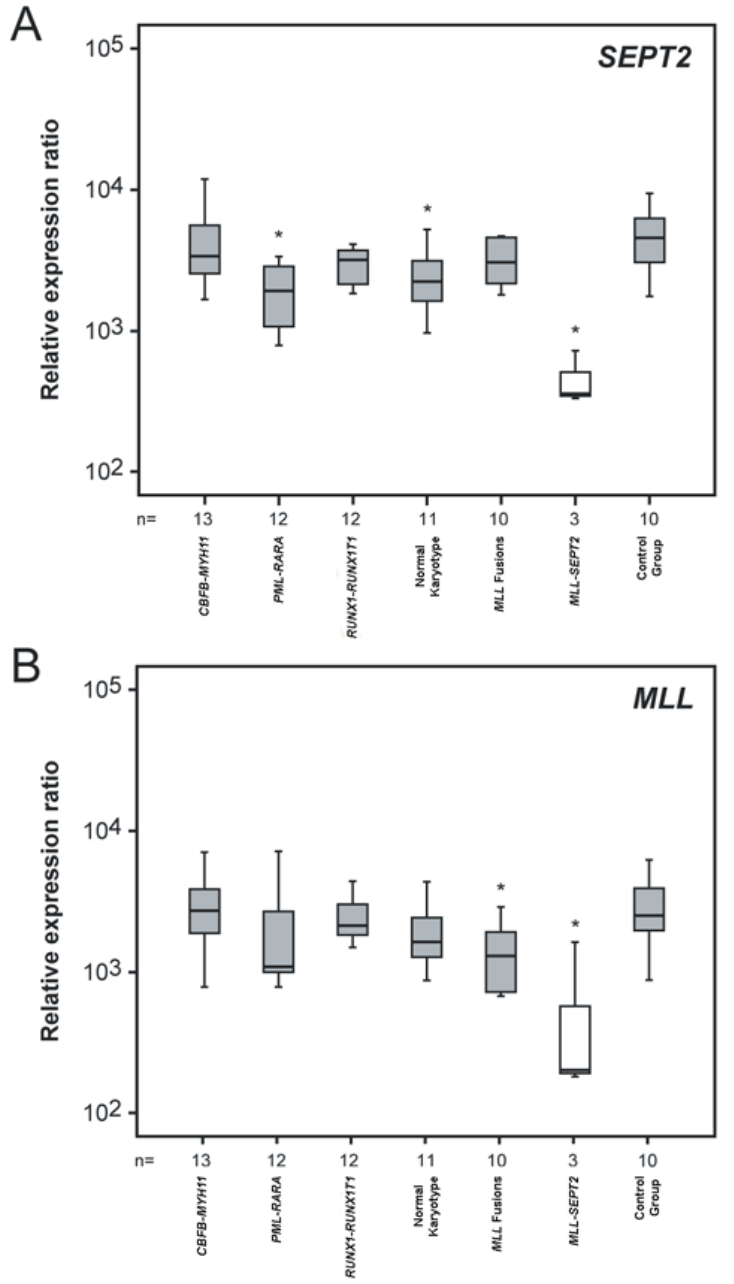

Figure I

Box-plots of normalized expression values for SEPT2 (A) and MLL (B) in subgroups of myeloid malignancies and control samples. Asterisks denote significant differences when compared with the normal control group. The combined expression of MLL-SEPT2 and MLL or SEPT2 was significantly lower in MLL-SEPT2 patients compared to all other groups (see Table I for significance values).

wild-type MLL expression between the non-MLL-SEPT2 leukemia subgroups and the normal controls, with the exception of the significantly lower expression seen in the patient group with $M L L$ fusions with other partners other than SEPT2 $(\mathrm{q}=0,023)$.

\section{Discussion}

Fusion oncogenes are generally thought to contribute to carcinogenesis by either causing over-expression of the 3 ' partner due to promoter swap or by originating a chimeric 
MATERIAL AND METHODS, RESULTS AND DISCUSSION

Table I: Normalized values for the expression of MLL-SEPT2 and MLL or SEPT2 in subgroups of hematologic malignacies and normal controls

\begin{tabular}{|c|c|c|c|c|c|c|c|c|c|}
\hline \multirow[b]{2}{*}{ Genetic groups } & \multicolumn{3}{|c|}{ SEPT2 + MLL-SEPT2 } & \multicolumn{6}{|c|}{ MLL + MLL-SEPT2 } \\
\hline & $\mathrm{n}$ & $\begin{array}{c}\text { Median } \\
(\mathrm{P} 25-\mathrm{P} 75)\end{array}$ & Fold Change (a) & $P$-value (a) & $P$-value (b) & $\begin{array}{c}\text { Median } \\
(\text { P25-P75) }\end{array}$ & Fold Change (a) & $P$-value (a) & $P$-value (b) \\
\hline CBFB-MYHII & 13 & $\begin{array}{c}3388 \\
(24 \mid I-5634)\end{array}$ & 9.4 & 0.004 & Ns & $\begin{array}{c}2692 \\
(1698-5099)\end{array}$ & 13.4 & 0.025 & ns \\
\hline PML-RARA & 12 & $\begin{array}{c}1957 \\
(1055-2904)\end{array}$ & 5.4 & 0.004 & 0.001 & $\begin{array}{c}1083 \\
(97 \mid-2698)\end{array}$ & 5.4 & ns & ns \\
\hline RUNXI-RUNXITI & 12 & $\begin{array}{c}3187 \\
(2100-3760)\end{array}$ & 8.9 & 0.004 & ns & $\begin{array}{c}2107 \\
(1765-3018)\end{array}$ & 10.5 & 0.018 & ns \\
\hline Normal Karyotype & II & $\begin{array}{c}2242 \\
(1604-3424)\end{array}$ & 6.2 & 0.005 & 0.010 & $\begin{array}{c}1621 \\
(1012-2895)\end{array}$ & 8.1 & ns & ns \\
\hline MLL Fusions & 10 & $\begin{array}{c}3069 \\
(2159-4600)\end{array}$ & 8.5 & 0.007 & ns & $\begin{array}{c}1292 \\
(708-2050)\end{array}$ & 6.4 & ns & 0.023 \\
\hline MLL-SEPT2 & 3 & $\begin{array}{c}359 \\
(333-724)\end{array}$ & 1.0 & - & 0.007 & $\begin{array}{c}200 \\
(180-1612)\end{array}$ & 1.0 & - & 0.028 \\
\hline Normal Control & 10 & $\begin{array}{c}4599 \\
(2939-6365)\end{array}$ & 12.8 & 0.007 & - & $\begin{array}{c}2494 \\
(1749-3929)\end{array}$ & 12.4 & 0.028 & - \\
\hline
\end{tabular}

(a) Comparison of each group with MLL-SEPT2 patients; (b) Comparison of each group with normal control group; (P25) percentile 25; (P75) percentile 75 .

protein with new biochemical properties. Surprisingly, when compared with the normal controls, we found a 12.8 -fold reduction of the combined MLL-SEPT2 and wild-type SEPT2 expression in myeloid neoplasias with the MLL-SEPT2 gene fusion, which is accompanied by 12.4-fold down-regulation of the combined MLL-SEPT2 and wild-type $M L L$ expression. The down-regulation of SEPT2 in MLL-SEPT2 myeloid neoplasias was also statistically significant when compared with all other leukemia genetic subgroups (including those with other MLL gene fusions). It is conceivable that deregulation of SEPT2 expression can occur as a result of its fusion with $M L L$ (for example by haplo-insufficiency), since the MLL-SEPT2 gene is under the control of the MLL promoter. However, not only the magnitude of SEPT2 under-expression far exceeds the maximum $50 \%$ reduction that would be expected if one of the SEPT2 gene copies has its expression shutdown, but wild-type MLL expression seems to be strongly down-regulated as well. This suggests a concomitant down-regulation of wild-type $M L L$, wild-type SEPT2, and the MLL-SEPT2 fusion gene. The fact that $M L L$, SEPT2, and MLL-SEPT2 map to distinct chromosomes excludes a localized transcriptional repression affecting contiguous genes via a long-range control element as a possible mechanism.

Interestingly, $M L L$ expression was also down-regulated in the group of MLL fusions other than MLL-SEPT2, when compared with the normal control group. Wild-type $M L L$ down-regulation associated with $M L L$ abnormalities was previously observed in AML with $M L L$ partial tandem duplication (PTD) [27]. In that instance, the wild-type
MLL transcript derived from the non-rearranged $M L L$ allele was absent in the majority of cases of MLL-PTD, with the authors suggesting that the silencing of wild-type $M L L$ may result from the action of the MLL-PTD protein via an auto-regulatory mechanism [27], which has so far not been described for MLL-SEPT2. In addition, downregulation of $M L L$ when fused with a partner gene was also previously observed in MLL-MLLT3 patients [27], suggesting that this can be a common event in $M L L$ related leukemia. Since MLL fusion proteins seem to transform by a gain-of-function mechanism with conversion of the MLL chimera into a potent transcriptional activator $[28,29]$, quantitative oscillations in wild-type and chimeric $M L L$ expression level presumably do not abrogate the leukemogenic properties of $M L L$ fusion proteins. One alternative explanation for the observed down-regulation of MLL, SEPT2 and MLL-SEPT2 is the involvement of a transcriptional rather than post-transcriptional mechanism, for instance regulated via an epigenetic mark. DNA methylation within the promoter region of a gene can result in chromatin compaction and inhibition or downregulation of gene transcription, and aberrant promoter methylation in cis is often responsible for gene silencing in a variety of malignancies [30]. However, the absence of DNA methylation in the CpG island located 5 ' of the SEPT2 gene (encompassing the predicted SEPT2 promoter region) suggests that hypermethylation of wild-type SEPT2 is probably not the mechanism responsible for the observed gene silencing but, since in only one MLL-SEPT2 case DNA was available to perform methylation analysis, a definitive conclusion cannot be draw. 
How can SEPT2 down-regulation be associated with leukemogenesis? Mammalian septins have been linked with two distinct steps in cell division, namely during chromosome segregation and during cytokinesis, as depletion of septins by siRNA result in defects in both of these processes $[31,32]$. SEPT2 function is dependent of the formation of core oligomeric complexes with SEPT6 and SEPT7, and this septin heterotrimer is a recognized regulator of microtubule stability, with septin depletion resulting in a marked stabilization of microtubules and mitotic defects in vivo $[1,33]$. It is known that proper organization of the cytoskeleton, including that of septin filaments, is required for cell-cycle progression and, as a consequence, septins are indirectly involved in driving or halting the cell-cycle engine [34]. In addition, the SEPT2SEPT6-SEPT7 complex can directly regulate cell-cycle progression by sequestering key signaling molecules involved in the DNA damage response and cell-cycle progression $[33,34]$. Down-regulation of the expression of septin genes has been described previously in neoplasia. Expression of the mitochondrial ARTS protein, a splice variant of the SEPT4 gene, is lost in the majority of childhood acute lymphoblastic leukemias and SEPT9 expression is downregulated by promoter methylation in head and neck squamous cell carcinomas, suggesting that both genes can function as tumor suppressor genes [35,36]. SEPT2 may also play a role in the pathogenesis of other AML subtypes in which it is not involved as fusion partner, since we have uncovered significant SEPT2 RNA down-regulation in AML associated with the PML-RARA rearrangement and in AML with a normal karyotype.

SEPT2 is not the only septin family gene associated with hematological neoplasia. It has been shown that at least four other septins, SEPT5, SEPT6, SEPT9 and SEPT11, are also MLL fusion partners [9-13]. There is increasing evidence supporting the hypothesis that $M L L$ fusion partners are not randomly chosen, but rather functionally selected. For instance, the most frequent MLL fusion partners AFF1 (AF4), MLLT3 (AF9), MLLT1 (ENL) and MLLT10 (AF10) have been shown to belong to the same nuclear protein network [37]. Furthermore, the carboxyl-terminal domain of ELL and MLLT1O have been shown to be required for the leukemic transformation associated with the MLL-ELL and MLL-MLLT10 fusion proteins, respectively $[38,39]$.

\section{Conclusion}

We provide evidence of MLL and SEPT2 down-regulation in MLL-SEPT2 myeloid neoplasia, as well as MLL underexpression in AML with MLL fusions with other partners other than SEPT2 but, due to the small number of $M L L$ SEPT2 cases available, these results should be confirmed in a larger series of patients. Characterization of the expression profile of other MLL fusion partners, including other septins, in hematological malignancies may allow a better understanding of the pathobiological mechanisms of AML.

\section{Competing interests}

The authors declare that they have no competing interests.

\section{Authors' contributions}

NC designed and performed the research, analyzed the data and drafted the manuscript. JS performed the research and analyzed the data. SB performed the RT-PCR studies. VC performed the qMSP studies. FRR analyzed the data. SL, CC, LT, and JV performed the chromosome banding and molecular cytogenetic studies. SS, CHM, and $\mathrm{AB}$ characterized patients 60 and 61 and provide samples of both patients for RT-PCR and qRT-PCR studies. JMM and LN clinically assessed the patients. MRT coordinated the study and participated in manuscript writing. All authors read and approved the final manuscript.

\section{Additional material}

\section{Additional file 1}

Additional Table S1. Summary of clinical, molecular, and cytogenetic data of the 61 patients with hematological malignacies.

Click here for file

[http://www.biomedcentral.com/content/supplementary/14712407-9-147-S1.doc]

\section{Additional file 2}

Additional Table S2. Oligonucleotide primers and probes (5'FAM, 3'TAMRA) used in this study.

Click here for file

[http://www.biomedcentral.com/content/supplementary/14712407-9-147-S2.doc]

\section{Acknowledgements}

This research was supported by grants from the "Associação Portuguesa Contra a Leucemia" (2006-30.2.AP/MJ) and the "Comissão de Fomento da Investigação em Cuidados de Saúde" (P.I. 26/2007).

\section{References}

I. Weirich CS, Erzberger JP, Barral Y: The septin family of GTPases: architecture and dynamics. Nat Rev Mol Cell Biol 2008, 9:478-489.

2. Gladfelter AS, Montagna C: Seeking truth on Monte Verita. Workshop on the molecular biology and biochemistry of septins and septin function. EMBO Rep 2007, 8: I I 20- I I 26.

3. Joo E, Surka MC, Trimble WS: Mammalian SEPT2 is required for Joo E, Surka MC, Trimble WS: Mammalian SEPT2 is required for
scaffolding nonmuscle myosin II and its kinases. Dev Cell 2007, 13:677-690.

4. Hall PA, Russell SE: The pathobiology of the septin gene family. J Pathol 2004, 204:489-505.

5. Cerveira N, Correia C, Bizarro S, Pinto C, Lisboa S, Mariz JM, Marques M, Teixeira MR: SEPT2 is a new fusion partner of $M L L$ in acute myeloid leukemia with $t(2 ; 11)(q 37 ; q 23)$. Oncogene 2006, 25:6147-6152.

6. van Binsbergen $E$, de Weerdt $O$, Buijs $A$ : A new subtype of $M L L-$ SEPT2 fusion transcript in therapy-related acute myeloid leukemia with $t(2 ; 11)(q 37 ; q 23)$ : a case report and literature review. Cancer Genet Cytogenet 2007, 1 76:72-75. 
7. Snijder $\mathrm{S}$, Mellink $\mathrm{CH}$, Lelie $\mathrm{H}$ van der: Translocation $(2 ; 11)(q 37 ; q 23)$ in therapy-related myelodysplastic syndrome after treatment for acute promyelocytic leukemia. Cancer Genet Cytogenet 2008, 180: 149 -152

8. Cerveira N, Santos J, Pinheiro M, Snijder S, Lelie H van der, Mellink C, Teixeira MR: A novel MLL-SEPT2 fusion variant in therapyrelated myelodysplastic syndrome. Cancer Genet Cytogenet 2008, 185:62-64

9. Megonigal MD, Rappaport EF, Jones DH, Williams TM, Lovett BD, Kelly KM Lerou PH, Moulton T, Budarf ML Felix CA: $t(I 1 ; 22)(q 23 ; q$ II I 2) in acute myeloid leukemia of infant twins $t(1 ; ; 22)(q 23 ; q \mid l .2)$ in acute myeloid leukemia of infant twins
fuses MLL with $h C D C$ rel, a cell division cycle gene in the genomic region of deletion in DiGeorge and velocardiofacial syndromes. Proc Natl Acad Sci USA 1998, 95:64 I3-64I 8.

10. Osaka M, Rowley JD, Zeleznik-Le NJ: MSF (MLL septin-like fusion), a fusion partner gene of MLL, in a therapy-related acute myeloid leukemia with a $t(11 ; 17)(\mathbf{q} 23 ; \mathbf{q} 25)$. Proc Nat Acad Sci USA 1999, 96:6428-6433.

II. Taki T, Ohnishi H, Shinohara K, Sako M, Bessho F, Yanagisawa M, Hayashi Y: AFI7q25, a putative septin family gene, fuses the $M L L$ gene in acute myeloid leukemia with $\mathrm{t}(1 \mathrm{I} ; 17)(\mathrm{q} 23 ; \mathrm{q} 25)$. Cancer Res 1999, 59:4261-4265.

12. Ono R, Taki T, Taketani T, Kawaguchi H, Taniwaki M, Okamura T, Kawa K, Hanada R, Kobayashi M, Hayashi Y: SEPTIN6, a human homologue to mouse Septin6, is fused to MLL in infant acute myeloid leukemia with complex chromosomal abnormalities involving I / q23 and Xq24. Cancer Res 2002, 62:333-337.

13. Kojima K, Sakai I, Hasegawa A, Niiya H Azuma T, Matsuo Y, Fujii N Tanimoto M, Fujita S: FLJ10849, a septin family gene, fuses $M L L$ in a novel leukemia cell line CNLBCI derived from chronic neutrophilic leukemia in transformation with t(4; I )(q21;q23). Leukemia 2004, 18:998-1005.

14. Shaffer LG, Tommerup N: ISCN 2005 An International System for Human Cytogenetic Nomenclature Basel: Karger; 1995.

15. van Dongen J], Macintyre EA, Gabert JA, Delabesse E, Rossi V, Saglio G, Gottardi E, Rambaldi A, Dotti G, Griesinger F, Parreira A, Gameiro P, Diaz MG, Malec M, Langerak AW, San Miguel JF, Biondi A: Standardized RT-PCR analysis of fusion gene transcripts from chromosome aberrations in acute leukemia for detection of minimal residual disease. Report of the BIOMED-I Concerted Action: investigation of minimal residual disease in acute leukemia. Leukemia 1999, 13:1901-1928.

16. Chaplin T, Bernard O, Beverloo HB, Saha V, Hagemeijer A, Berger R, Young BD: The $t(10 ; 11)$ translocation in acute myeloid leukemia (M5) consistently fuses the leucine zipper motif of AFIO onto the HRX gene. Blood 1995, 86:2073-2076.

17. Poirel $H$, Rack K, Delabesse E, Radford-Weiss I, Troussard X, Debert C, Leboeuf D, Bastard C, Picard F, Veil-Buzyn A, Flandrin G, Bernard $O$, Macintyre E: Incidence and characterization of MLL gene (I q23) rearrangements in acute myeloid leukemia MI and M5. Blood 1996, 87:2496-2505.

18. Busson-Le Coniat M, Salomon-Nguyen F, Hillion J, Bernard OA, Berger R: MLL-AFIq fusion resulting from $t(I ; I I)$ in acute leukemia. Leukemia 1999, 13:302-306.

19. Shih LY, Liang DC, Fu JF, Wu JH, Wang PN, Lin TL, Dunn P, Kuo MC, Tang TC, Lin TH, Lai CL: Characterization of fusion partner genes in 114 patients with de novo acute myeloid leukemia and MLL rearrangement. Leukemia 2006, 20:218-223.

20. Gabert J, Beillard E, Velden VH van der, Bi W, Grimwade D, Pallisgaard N, Barbany G, Cazzaniga G, Cayuela JM, Cavé H, Pane F, Aerts JL, De Micheli D, Thirion X, Pradel V, González M, Viehmann S, Malec $M$, Saglio G, van Dongen Jj: Standardization and quality contro studies of 'real-time' quantitative reverse transcriptase polymerase chain reaction of fusion gene transcripts for residual disease detection in leukemia - a Europe Against Cancer proase detection in leukemia - a Eur

21. Beillard E, Pallisgaard N, Velden VH van der, Bi W, Dee R, Schoot E van der, Delabesse E, Macintyre E, Gottardi E, Saglio G, Watzinger F, Lion T, van Dongen J], Hokland P, Gabert J: Evaluation of candidate control genes for diagnosis and residual disease detection in leukemic patients using 'real-time' quantitative reverse-transcriptase polymerase chain reaction (RQ-PCR) - a Europe against cancer program. Leukemia 2003, 17:2474-2486.
22. Clark SJ, Harrison J, Paul CL, Frommer M: High sensitivity mapping of methylated cytosines. Nucleic Acids Res 1994, 22:2990-2997.

23. Takai D, Jones PA: The CpG island searcher. In Silico Biology 2003, 3:21.

24. Prestridge DS: Predicting Pol II promoter sequences using transcription factor binding sites. J Mol Biol I995, 249:923-932

25. Eads CA, Danenberg KD, Kawakami K, Saltz LB, Blake C, Shibata D, Danenberg PV, Laird PW: MethyLight: a high-throughput assay to measure DNA methylation. Nucleic Acids Res 2000, 28: E32.

26. Eads CA, Lord RV, Wickramasinghe K, Long TI, Kurumboor Sk, Bernstein L, Peters JH, DeMeester SR, DeMeester TR, Skinner KA, Laird PW: Epigenetic patterns in the progression of esophagea adenocarcinoma. Cancer Res 200I, 61:34I0-34I8.

27. Whitmann SP, Liu S, Vukosavljevic T, Rush LI, Liu C, Klisovic MI, Maharry K, Guimond M, Strout MP, Becknell B, Dorrance A, Klisovic RB, Plass C, Bloomfield CD, Marcucci G, Caligiuri MA: The MLL partial tandem duplication: evidence for recessive gain-offunction in acute myeloid leukemia identifies a novel patient subgroup for molecular-targeted therapy. Blood 2005, 106:345-352.

28. Schreiner SA, García-Cuéllar MP, Fey GH, Slany RK: The leukemogenic fusion of $M L L$ with ENL creates a novel transcriptional transactivator. Leukemia 1999, I 3: I525-1533.

29. Zeisig BB, Schreiner S, García-Cuéllar MP, Slany RK: Transcriptional activation is a key function encoded by MLL fusion partners. Leukemia 2003, 17:359-365.

30. Esteller M: Epigenetics in cancer. N Engl | Med 2008 , 358: I 148-1159.

3I. Kinoshita M, Kumar S, Mizoguchi A, Ide C, Kinoshita A, Haraguchi T. Hiraoka $Y$, Noda M: Nedd5, a mammalian septin, is a nove cytoskeletal component interacting with actin-based structures. Genes Dev 1997, I I:I535-1547.

32. Spiliotis ET, Kinoshita M, Nelson W]: A mitotic septin scaffold required for Mammalian chromosome congression and segregation. Science 2005, 307:178I-1785.

33. Kremer BE, Haystead T, Macara IG: Mammalian septins regulate microtubule stability through interaction with the microtubule-binding protein MAP4. Mol Biol Cell 2005, 16:4648-4659.

34. Kremer BE, Haystead T, Macara IG: Septins regulate actin organization and cell-cycle arrest through nuclear accumulation of NCK mediated by SOCS7. Cell 2007, 130:777-779.

35. Elhasid R, Sahar D, Merling A, Zivony Y, Rotem A, Ben-Arush M, Izraeli S, Bercovich D, Larisch S: Mitochondrial pro-apoptotic ARTS protein is lost in the majority of acute lymphoblastic leukemia patients. Oncogene 2004, 23:5468-5475.

36. Bennett KL, Karpenko M, Lin MT, Claus R, Arab K, Dyckhoff G, Plinkert $P$, Herpel E, Smiraglia D, Plass C: Frequently methylated tumor suppressor genes in head and neck squamous cell carcinoma. Cancer Res 2008, 68:4494-4499.

37. Meyer C, Schneider B, Jakob S, Strehl S, Attarbaschi A, Schnittger S, Schoch C, Jansen MWJC, van Dongen JJM, den Boer ML, Pieters R, Ennas M-G, Angelucci E, Koehl U, Greil J, Griesinger F, zur Stadt U, Eckert C, Szczepañski T, Niggli FK, Schäfer BW, Kempski H, Brady HJM, Zuna J, Trka J, Nigro LL, Biondi A, Delabesse E, Macintyre E, Stanulla M, Schrappe M, Haas OA, Burmeister T, Dingermann T, Klingebiel T, Marschalek R: The MLL recombinome of acute leukemias. Leukemia 2006, 20:777-784.

38. DiMartino JF, Miller T, Ayton PM, Landewe T, Hess JL, Clearly ML, Shilatifard A: A carboxy-terminal domain of ELL is required and sufficient for immortalization of myeloid progenitors by MLL-ELL. Blood 2000, 96:3887-3893.

39. DiMartino JF, Ayton PM, Chen EH, Naftzger CC, Young BD, Clearly $M L:$ The AFI0 leucine zipper is required for leukemic transformation of myeloid progenitors by MLL-AFI 0. Blood 2002, 99:3780-3785.

\section{Pre-publication history}

The pre-publication history for this paper can be accessed here:

http://www.biomedcentral.com/1471-2407/9/147/pre pub 


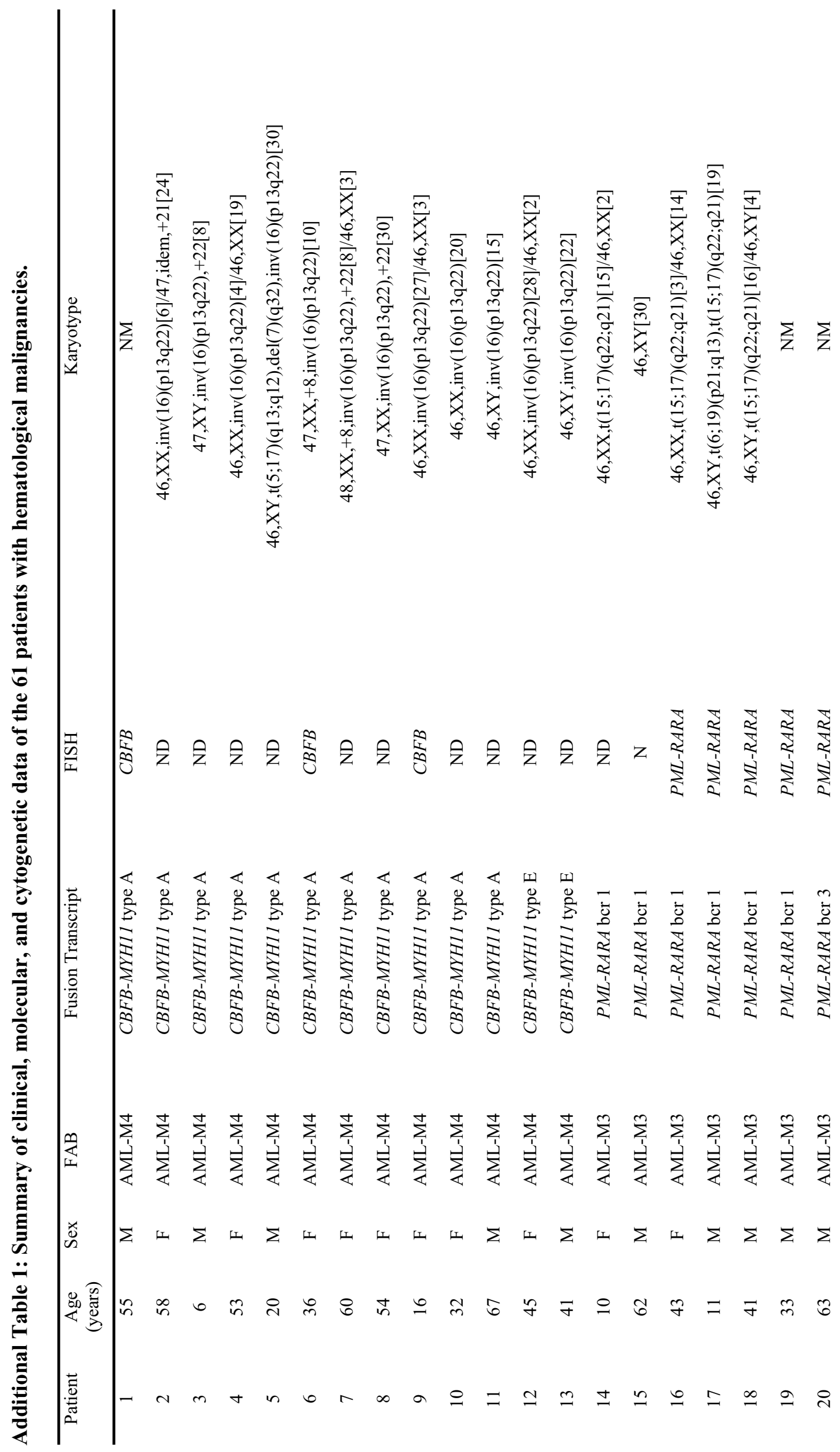




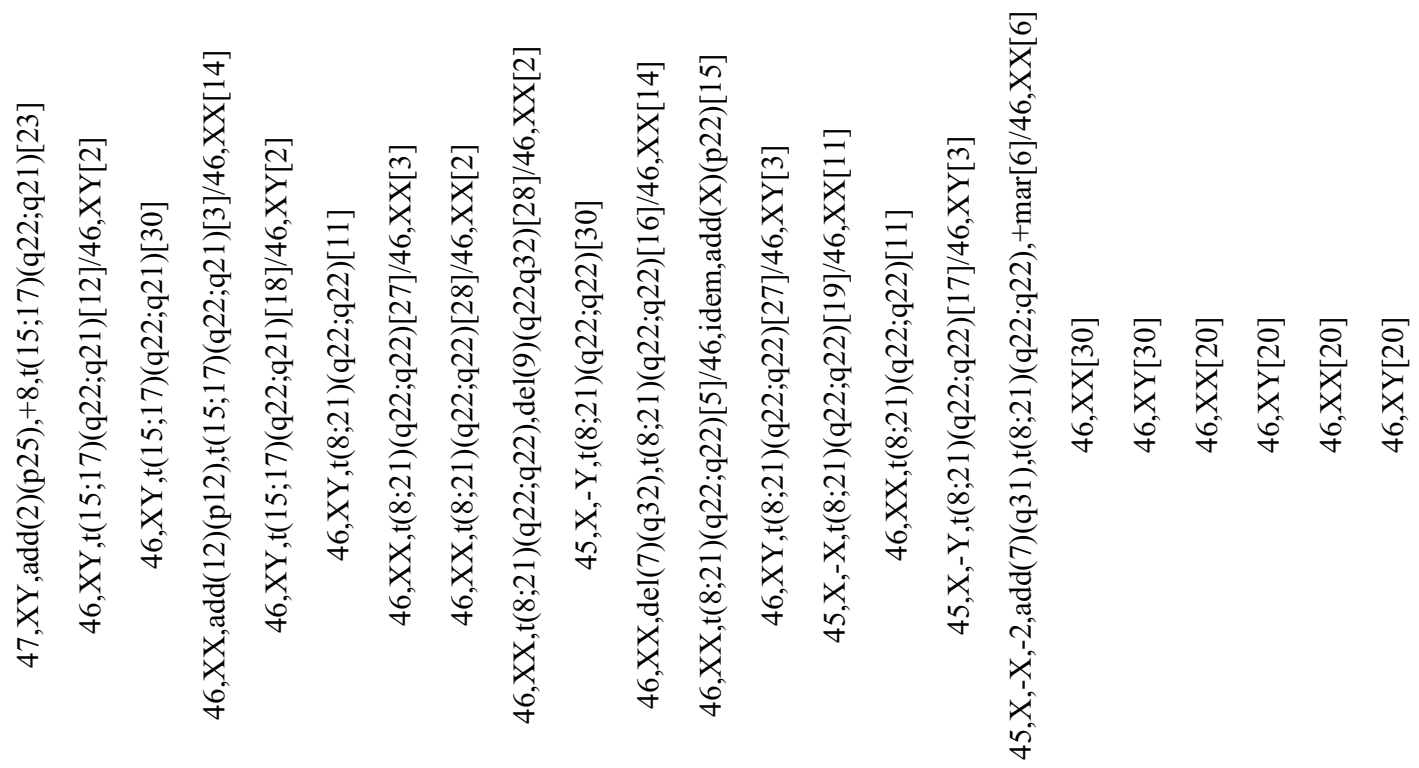

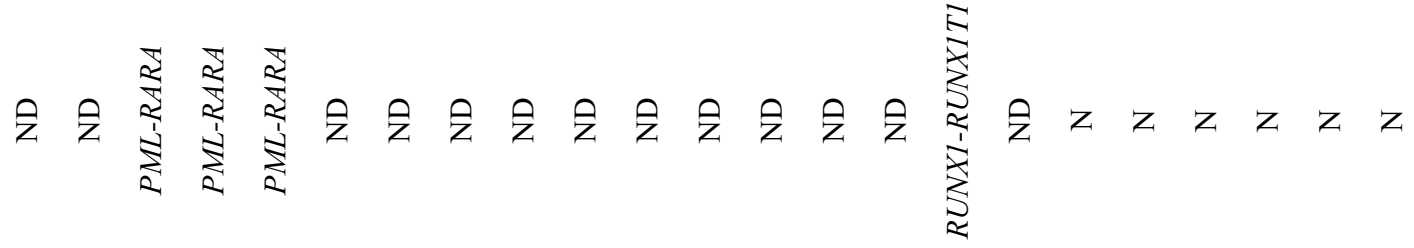

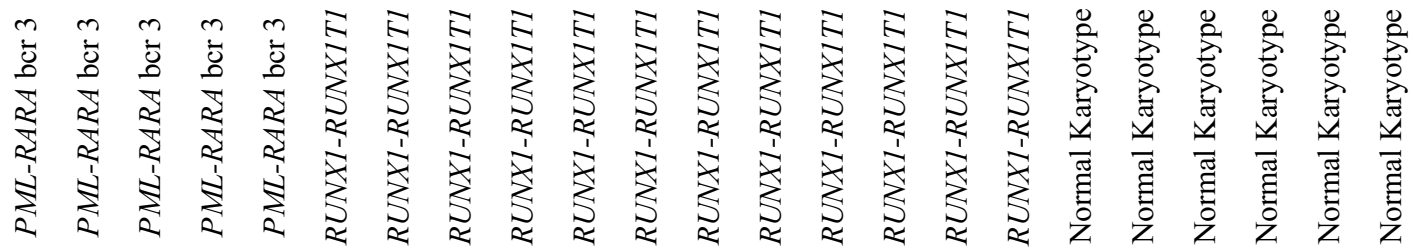

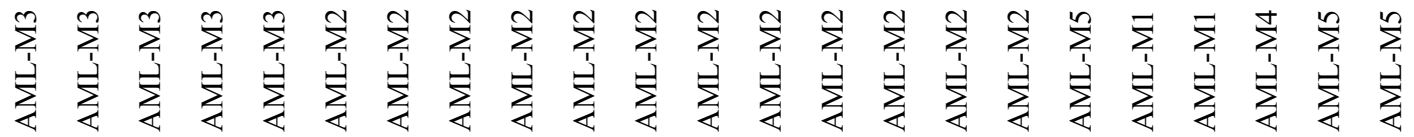

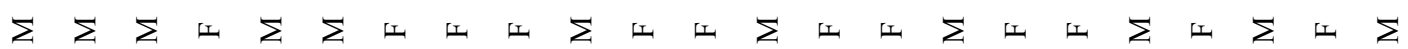

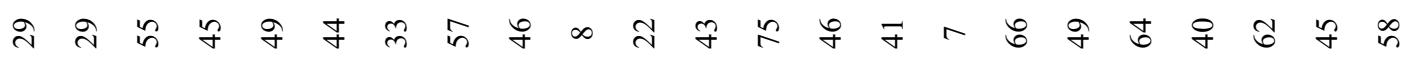

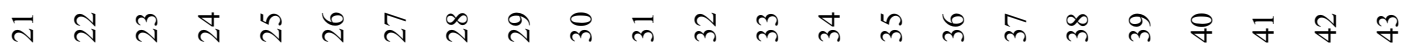




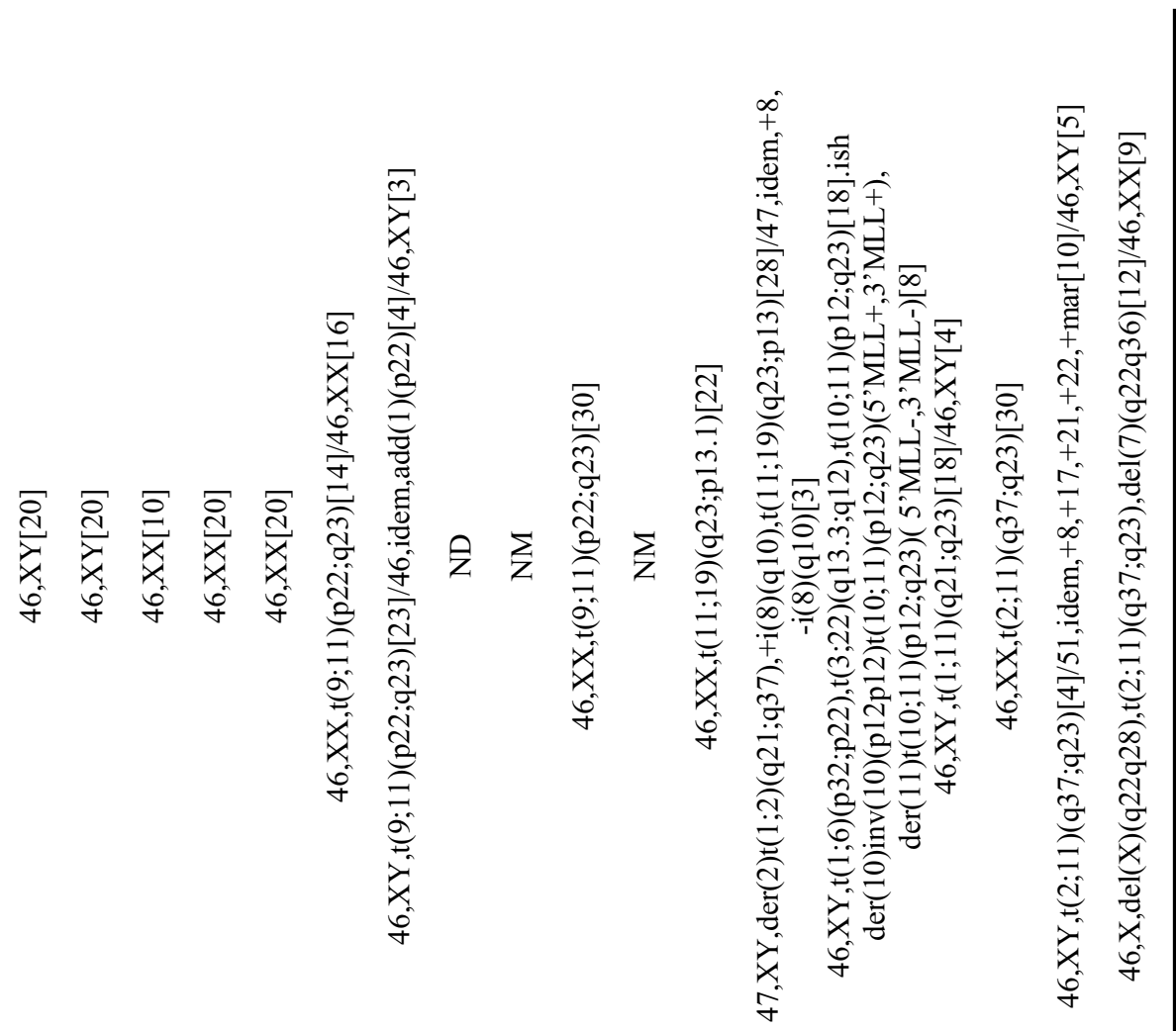

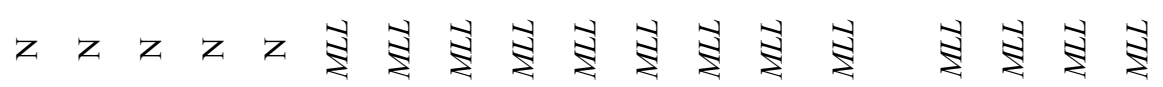

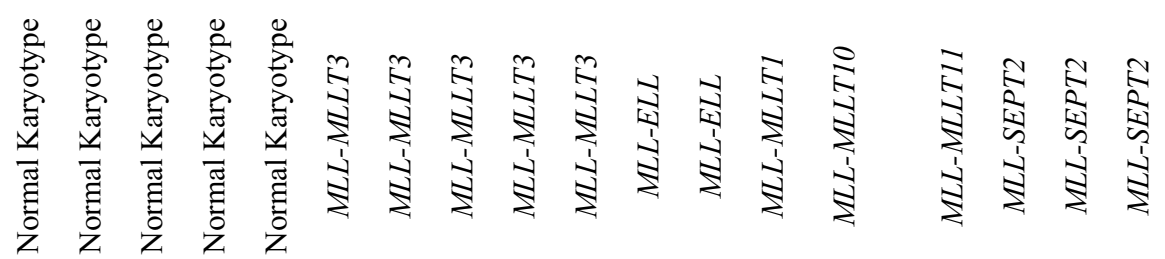

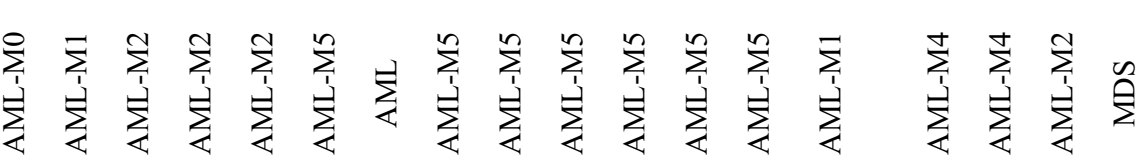
$\Sigma \Sigma$ 山山山山

ช

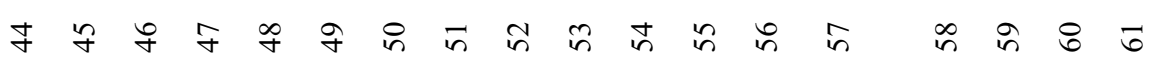




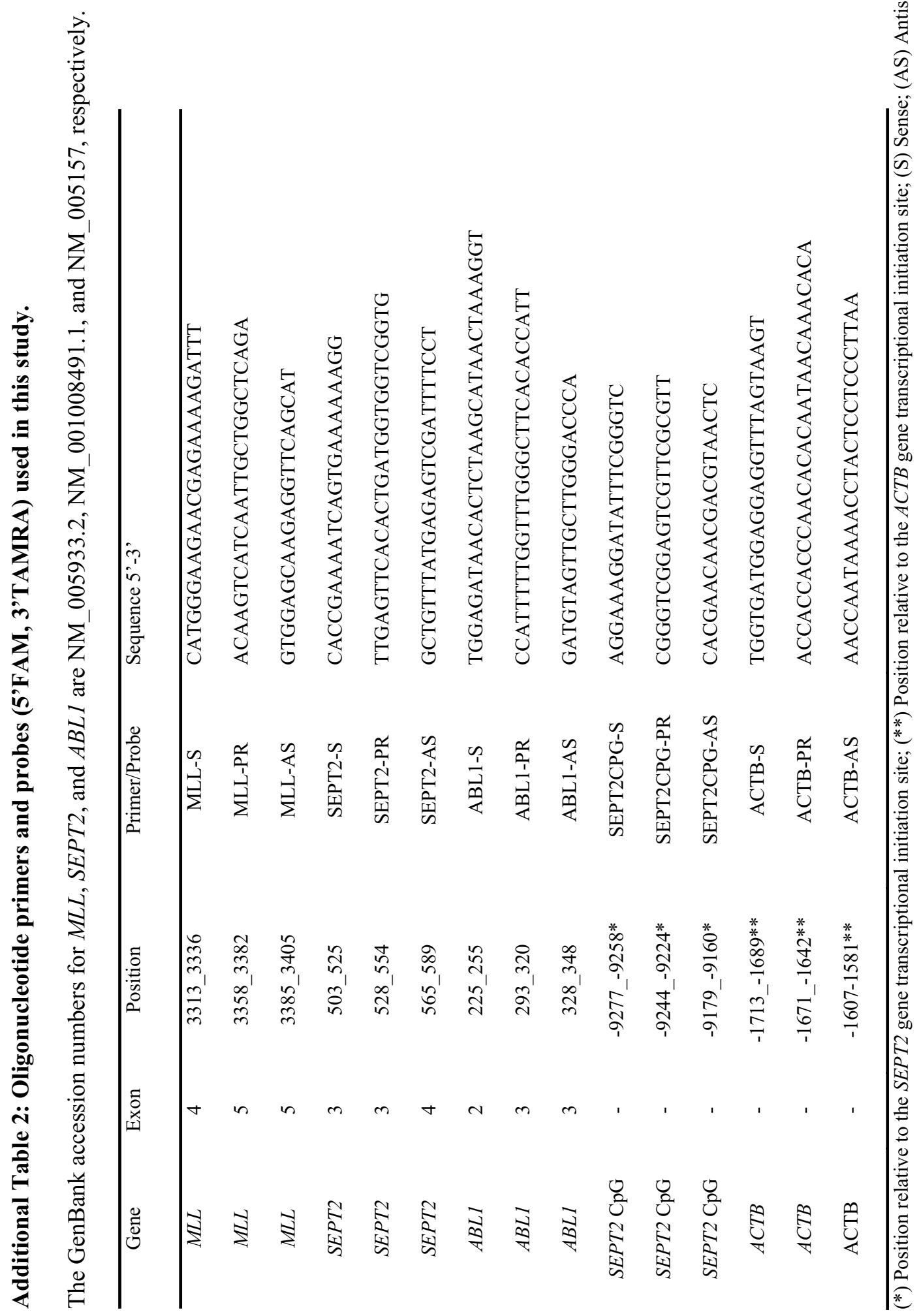


MATERIAL AND METHODS, RESULTS AND DISCUSSION 
PAPER \#6

Joana Santos, Nuno Cerveira, Susana Bizarro, Franclim R. Ribeiro, Cecília Correia, Lurdes Torres, Susana Lisboa, Joana Vieira, José M. Mariz, Lucília Norton, Simone Snijder, Clemens $H$ Mellink, Arjan Buijs, Lee-Yung Shih, Sabine Strehl, Francesca Micci, Sverre Heim, Manuel R. Teixeira

\section{EXPRESSION PATTERN OF THE SEPTIN GENE FAMILY IN ACUTE MYELOID LEUKEMIAS WITH AND WITHOUT MLL-SEPT FUSION GENES}


MATERIAL AND METHODS, RESULTS AND DISCUSSION 


\section{Expression pattern of the septin gene family in acute myeloid leukemias with and without MLL-SEPT fusion genes}

Joana Santos ${ }^{a}$, Nuno Cerveira ${ }^{a}$, Susana Bizarro ${ }^{a}$, Franclim R. Ribeiro $^{a}$, Cecília Correia $^{a}$, Lurdes Torres ${ }^{a}$, Susana Lisboa ${ }^{a}$, Joana Vieira ${ }^{a}$, José M. Mariz ${ }^{b}$, Lucília Norton ${ }^{c}$, Simone Snijder ${ }^{d}$, Clemens H. Mellink ${ }^{d}$, Arjan Buijs ${ }^{\mathrm{e}}$, Lee-Yung Shih ${ }^{\mathrm{f}}$, Sabine Strehl ${ }^{\mathrm{g}}$, Francesca Micci ${ }^{\mathrm{h}}$, Sverre Heim ${ }^{\mathrm{h}, \mathrm{i}}$, Manuel R. Teixeira ${ }^{\mathrm{a}, \mathrm{j}, \text {, }}$

a Department of Genetics, Portuguese Oncology Institute, Porto, Portugal

${ }^{\mathrm{b}}$ Department of Hemato-Oncology, Portuguese Oncology Institute, Porto, Portugal

c Department of Pediatrics, Portuguese Oncology Institute, Porto, Portugal

d Department of Clinical Genetics, Academic Medical Center, Amsterdam, The Netherlands

e Department of Medical Genetics, University Medical Center, Utrecht, The Netherlands

f Division of Hematology-Oncology, Department of Internal Medicine, Chang Gung Memorial Hospital,

Chang Gung University, Taoyuan, Taiwan

g Children's Cancer Research Institute (CCRI), St. Anna Kinderkrebsforschung, Vienna, Austria

h Department of Medical Genetics, The Norwegian Radiumhospital, Oslo University Hospital, Oslo, Norway

${ }^{\mathrm{i}}$ Medical Faculty, University of Oslo, Oslo, Norway

${ }^{\mathrm{j}}$ Abel Salazar Biomedical Sciences Institute (ICBAS), Porto, Portugal

\section{A R T I C L E I N F O}

\section{Article history:}

Received 25 June 2009

Received in revised form 11 August 2009

Accepted 14 August 2009

Available online 12 September 2009

\section{Keywords:}

Septin

Gene expression

$M L L$

Gene fusion

Myeloid neoplasia

\begin{abstract}
A B S T R A C T
Septins are proteins associated with crucial steps in cell division and cellular integrity. In humans, 14 septin genes have been identified, of which five (SEPT2, SEPT5, SEPT6, SEPT9, and SEPT11) are known to participate in reciprocal translocations with the $M L L$ gene in myeloid neoplasias. We have recently shown a significant down-regulation of both SEPT2 and MLL in myeloid neoplasias with the MLL-SEPT2 fusion gene. In this study, we examined the expression pattern of the other 13 known septin genes in altogether 67 cases of myeloid neoplasia, including three patients with the MLL-SEPT2 fusion gene, four with MLL-SEPT6 fusion, and three patients with the MLL-SEPT9 fusion gene. When compared with normal controls, a statistically significant down-regulation was observed for the expression of both MLL (6.4-fold; $p=0.008)$ and SEPT6 (1.7-fold; $p=0.002)$ in MLL-SEPT6 leukemia. Significant down-regulation of MLL was also found in MLL-MLLT3 leukemias. In addition, there was a trend for SEPT9 down-regulation in MLLSEPT9 leukemias (4.6-fold; $p=0.077$ ). Using hierarchical clustering analysis to compare acute myeloid leukemia genetic subgroups based on their similarity of septin expression changes, we found that $M L L-$ SEPT2 and MLL-SEPT6 neoplasias cluster together apart from the remaining subgroups and that PML-RARA leukemia presents under-expression of most septin family genes.
\end{abstract}

(c) 2009 Elsevier Ltd. All rights reserved.

\section{Introduction}

The septins are an evolutionarily conserved family of GTPbinding proteins involved in several processes of cell division and cellular integrity, including polarity establishment, maintenance of membrane dynamics, vesicle trafficking, exocytosis, cytoskeleton remodeling, and apoptosis [1]. There are 14 known human septin genes (SEPT1 to SEPT14) [2,3] and the complexity of this gene family

\footnotetext{
* Corresponding author at: Department of Genetics, Portuguese Oncology Institute, Rua Dr. António Bernardino de Almeida, 4200-072 Porto, Portugal. Tel.: +351 225084000; fax: +351 225084016 .

E-mail address: manuel.teixeira@ipoporto.min-saude.pt (M.R. Teixeira).
}

is further increased by extensive alternative splicing giving rise to multiple isoforms, some of which are tissue specific [1].

Recent reports link septins to various diseases in man, including cancer [1]. For instance, we and others have identified five septin genes, SEPT2, SEPT5, SEPT6, SEPT9, and SEPT11, that are fusion partners of the $M L L$ gene in patients with myeloid neoplasia, making septins the protein family with the most members involved in $M L L$-related leukemogenesis [1,4-14]. Recently, we quantified $M L L$ and SEPT2 gene expression in the major genetic subgroups of acute myeloid leukemia (AML) as well as in all three cases of MLLSEPT2 associated myeloid neoplasia so far described in the literature [15]. We showed that both MLL and SEPT2 are down-regulated in MLL-SEPT2 myeloid neoplasia as compared to normal bone marrow and other AML genetic subgroups, but statistically significant SEPT2 
down-regulation was also observed in AML with the PML-RARA rearrangement [15].

In this study, we set out to characterize the expression pattern at the RNA level of all other known septin family genes and of the $M L L$ gene in different AML genetic subgroups, including 10 patients with MLL-SEPT2, MLL-SEPT6 or MLL-SEPT9 fusion genes.

\section{Material and methods \\ 2.1. Patients}

We studied 67 bone marrow samples collected at diagnosis from the same number of patients with myeloid neoplasia (age range 1-75 years) selected to represent the major AML genetic subgroups, including 12 cases with RUNX1-RUNX1T1 rearrangement, 13 cases with CBFB-MYH11 rearrangement, 12 cases with PML-RARA rearrangement, 10 cases with normal karyotype, 10 cases with rearrangements of the $M L L$ gene with fusion partners other than septins, and 10 cases with MLL-SEPT rearrangements, including three with MLL-SEPT2, four with MLL-SEPT6, and three with MLL-SEPT9 (Table S1). This series of patients is the same as the one in which we previously quantified SEPT2 and MLL [15], with the exception of one normal karyotype patient with limited sample availability and the cases with MLL-SEPT6 and MLL-SEPT9 fusions. As a control group, we analyzed bone marrow samples obtained from 10 individuals found not to have a neoplastic hematological disease. The cytogenetic analysis and molecular characterization of all patients was described earlier. All but patients 59, 60, and 62 to 66 were treated at the Portuguese Oncology Institute, Porto, Portugal [15]. Patients 59 and 60 were treated in the Netherlands at the St. Antonius Hospital, Nieuwegein [16] and at the Amsterdam Academic Medical Center [17], respectively, patients 62 and 66 were admitted to the Chang Gung Memorial Hospital (Taoyuan, Taiwan) $[18,19]$, patients 63 and 64 were treated at the Rikshospitalet Department of Pediatrics (Oslo, Norway) [14] and the St Olaf University Hospital Department of Pediatrics (Trondheim, Norway) [14], respectively, and patient 65 was treated at the St Anna Children's Hospital (Vienna, Austria) [20]. In these cases, cDNA was obtained to perform molecular studies. The institutional review board approved this study.

2.2. RNA extraction and CDNA synthesis

Total RNA was extracted from the diagnostic bone marrow sample of patients $1-58,61$, and 67 and controls using $1 \mathrm{ml}$ of Tripure isolation reagent (Roche Diagnostics, Indianapolis, USA) and quantified in a NanoDrop ND-100 spectrophotometer (NanoDrop technologies, Wilmington, USA) according to the manufacturer's instructions. For cDNA synthesis, $1 \mu \mathrm{g}$ of total RNA was subjected to reverse transcription with random hexamers using the Superscript III First-Strand Synthesis System for RT-PCR (Invitrogen, Carlsbad, USA) according to the manufacturer's instructions. The cDNA was eluted in $30 \mu \mathrm{l}$ of RNAse free water. cDNA quantity and quality were assessed in a NanoDrop ND-100 spectrophotometer (NanoDrop Technologies, Wilmington, USA).

\subsection{Quantitative RT-PCR}

We analyzed the RNA expression of SEPT1 to SEPT14 and of the MLL gene by RealTime PCR on an ABI PRISM 7000 Sequence Detection System (Applied BioSystems, Foster City, CA). Primers and probes were designed with Primer Express 2.0 (Applied BioSystems) to detect all septin isoforms (Table S2). Primers and probes for the ABL1 gene, used as endogenous control, were previously described and approved for qRTPCR based diagnosis and minimal residual disease detection in leukemia patients, as this gene is similarly expressed in normal and leukemic samples (Table S2) [21,22]

To determine the relative expression levels of the target gene in each sample, the relative amount of the target gene was calibrated to the relative amount of the internal reference gene and expressed in terms of ratios between the target gene and the internal reference multiplied by 100 for easier tabulation (target gene/ABL $1 \times 100$ ). PCR reactions were performed in a $25 \mu \mathrm{l}$ volume containing $5 \mu \mathrm{l}$ of synthesized cDNA, $12.5 \mu$ l of TaqMan universal PCR master mix System (Applied BioSystems), $0.3 \mu \mathrm{M}$ of each primer, and $0.2 \mu \mathrm{M}$ of each probe. PCR was performed in separated wells for each primer/probe set and each sample was run in triplicate. PCR parameters were as follows: $50^{\circ} \mathrm{C}$ for $2 \mathrm{~min}, 95^{\circ} \mathrm{C}$ for $10 \mathrm{~min}$, followed by 50 cycles at $95^{\circ} \mathrm{C}$ for $15 \mathrm{~s}$ and $60^{\circ} \mathrm{C}$ for $1 \mathrm{~min}$. Each plate included negative controls and serial dilutions of a positive control to construct a standard curve for each gene analyzed.

\subsection{Statistical analysis}

Normalized expression values for the genes studied were compared among the different sample groups using the non-parametric Kruskal-Wallis $\mathrm{H}$ and Mann-Whitney $U$ tests. All statistical analyses were performed using SPSS version 15.0 (SPSS, Chicago, USA). $p$ values were considered statistically significant when smaller than 0.05 for $M L L$ and smaller than 0.01 for the septin family of genes.

When working with large datasets, such as the septin gene family, several multivariate statistics can be applied to simplify data interpretation and to find underlying relationships between available variables. Hierarchical clustering anal-

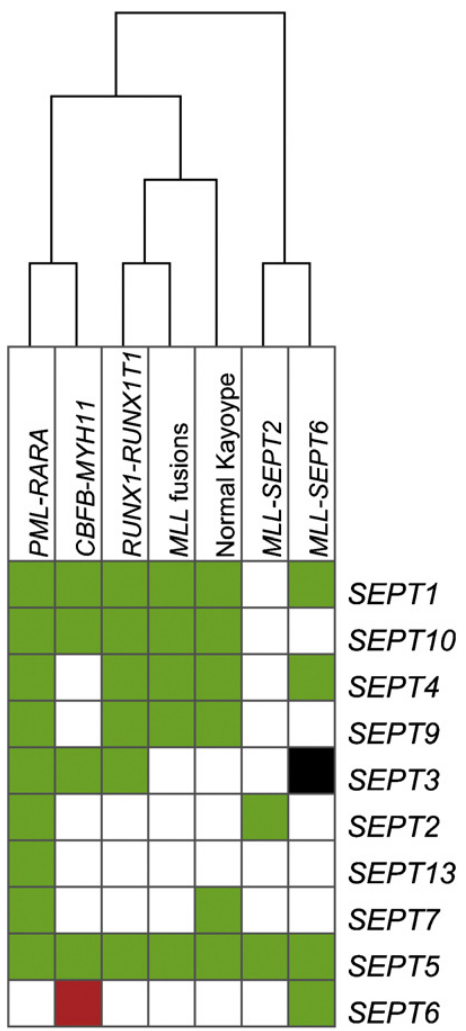

Fig. 1. Hierarchical clustering analysis based on statistically significant $(p<0.01)$ differences observed in the distinct AML genetic subgroups. AML with MLL-SEPT2 or MLL-SEPT6 were distinct from the remaining AML subgroups analyzed regarding the pattern of septin expression. Red box - over-expression; green box - underexpression; black box - not available; white box - no significant difference (For interpretation of the references to color in this figure legend, the reader is referred to the web version of the article).

ysis (HCA), through the use of standard statistical algorithms, clusters septin expression changes and AML genetic subgroups based on their similarity, with the results being visualized in the form of a dendogram. Data for HCA were coded as +1 for significant over-expression, -1 for significant under-expression, and 0 for nonsignificant differences. The HCA was performed in J-Express Pro 2.5 using Pearson's correlation.

\section{Results}

Hierarchical clustering analysis (HCA) of statistically significant septin expression changes in distinct AML genetic subgroups is shown in Fig. 1. Normalized expression levels for SEPT1 to SEPT13 and $M L L$ within each patient group are shown in Table 1 and Fig. 2. SEPT14 gene expression was not detected in any of the samples studied. SEPT8, SEPT11, and SEPT12 expression changes were not statistically significant.

\subsection{MLL-SEPT2 myeloid neoplasia}

The SEPT2 and MLL relative expression values for this leukemia subgroup were previously published [15], evidencing downregulation of both SEPT2 (12.8-fold; $p=0.007$ ) and MLL (12.4-fold; $p=0.028$ ) (Table 1). Regarding the remaining septin genes, a statistically significant down-regulation of SEPT5 expression was observed in patients 58 to 60 when compared with normal controls (30.8-fold; $p=0.007$ ). Due to limited sample availability, it was not possible to quantify the expression levels of SEPT12 in 


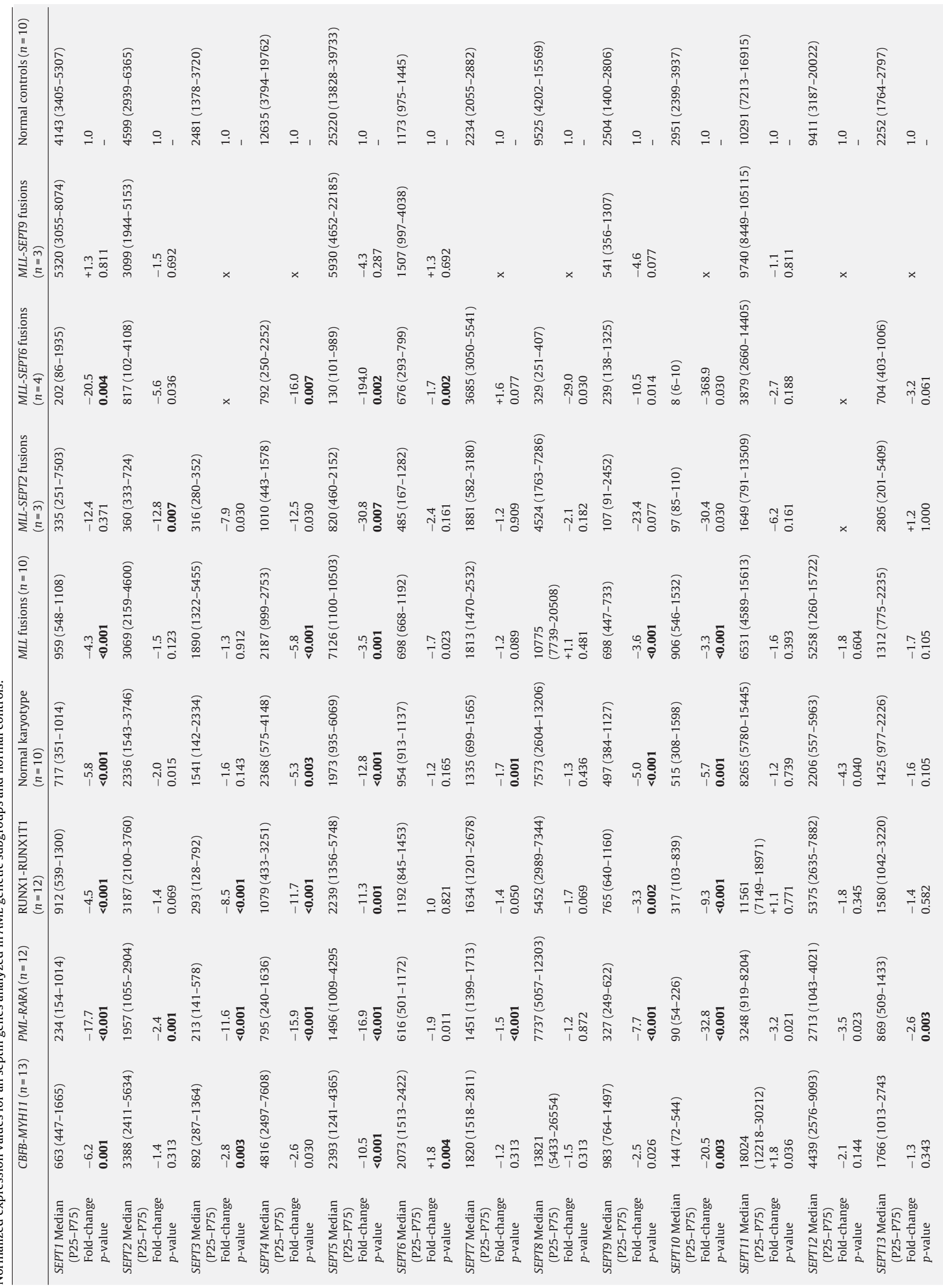




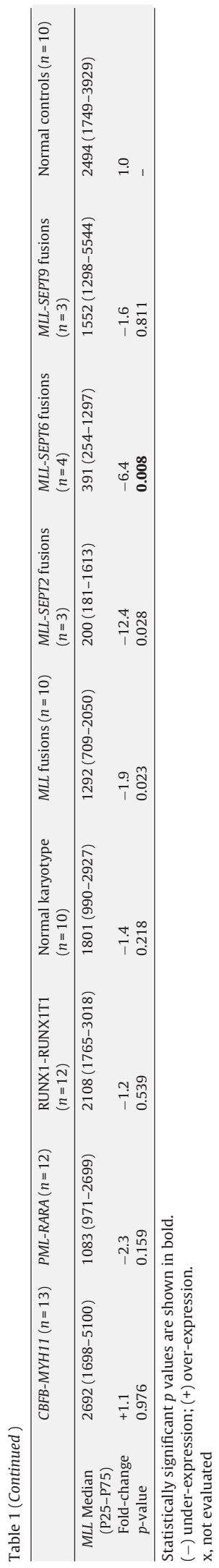

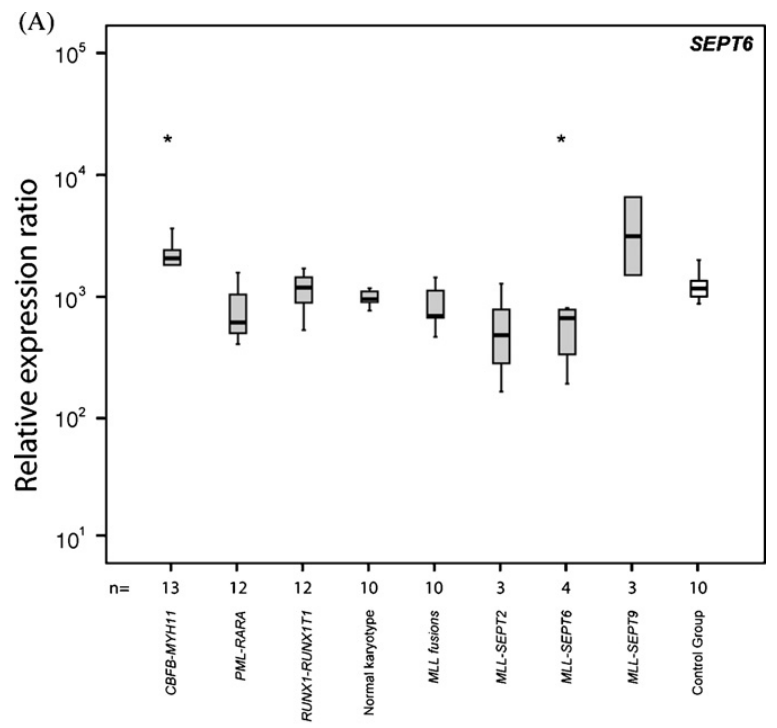

(B)

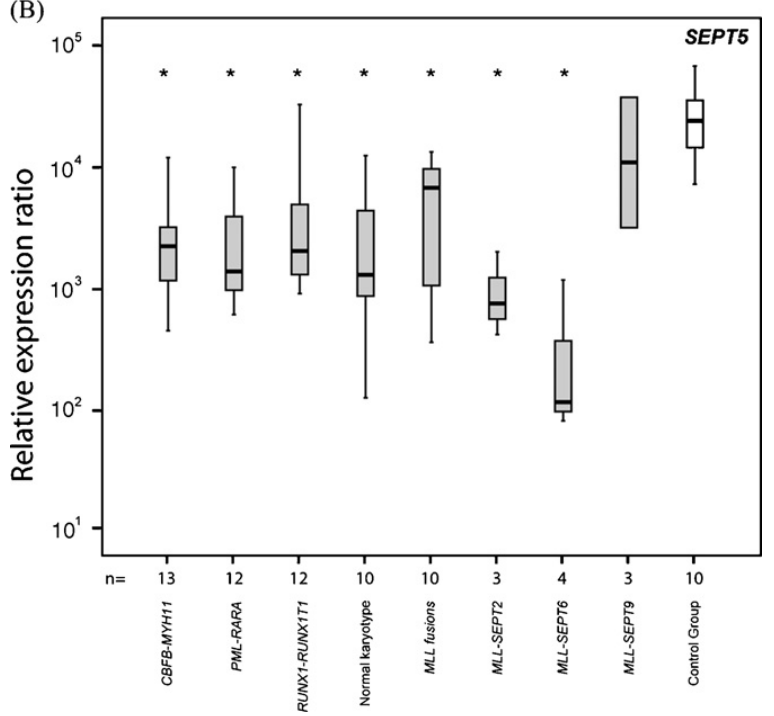

Fig. 2. Box-plots of normalized expression values for SEPT5 and SEPT6 in distinct AML genetic subgroups and control samples. Asterisks denote significant differences compared to control samples. (A) Box-plot of normalized expression values for SEPT6. (B) Box-plot of normalized expression values for SEPT5.

this group. No expression changes were detected for the remaining septins.

\subsection{MLL-SEPT6 AML}

A statistically significant down-regulation was observed of both MLL (6.4-fold; $p=0.008$ ) and SEPT6 (1.7-fold; $p=0.002)$ in MLLSEPT6 leukemia when compared with the normal controls (Fig. 2A). In addition, the down-regulation of gene expression was also statistically significant for SEPT1 (20.5-fold; $p=0.004)$, SEPT4 (16.0-fold; $p=0.007$ ), and SEPT5 (194.0-fold; $p=0.002$ ) in patients 61 to 64 when compared with normal controls. The expression levels of SEPT3 and SEPT12 were not evaluated in this group due to limited sample availability. 


\subsection{MLL-SEPT9 AML}

In this group (patients 65 to 67), as a result of very limited sample availability, it was only possible to quantify the expression levels of MLL, SEPT1, SEPT2, SEPT5, SEPT6, SEPT9, and SEPT11. No statistically significant differences in gene expression were observed for the septin genes analyzed compared with the normal controls, although a trend toward SEPT9 down-regulation was observed (4.6fold; $p=0.077$ ).

\subsection{CBFB-MYH11 AML}

In the CBFB-MYH11 AML genetic subgroup, a statistically significant under-expression was observed for SEPT1 (6.2-fold; $p=0.001$ ), SEPT3 (2.8-fold; $p=0.003$ ), SEPT5 ( 10.5 -fold; $p<0.001$ ), and SEPT10 (20.5-fold; $p=0.003$ ). On the other hand, we observed a statistically significant up-regulation of SEPT6 (1.8-fold; $p=0.004$ ).

\subsection{PML-RARA AML}

When compared with normal controls, PML-RARA cases showed a significant down-regulation of SEPT1 (17.7-fold; $p<0.001$ ), SEPT2 (2.4-fold; $p=0.001$ ), SEPT3 (11.6-fold; $p<0.001$ ), SEPT4 (15.9-fold; $p<0.001$ ), SEPT5 (16.9-fold; $p<0.001$ ), SEPT7 (1.5-fold; $p<0.001$ ), SEPT9 (7.7-fold; $p<0.001$ ), SEPT10 (32.8-fold; $p<0.001$ ), and SEPT13 (2.6-fold; $p=0.003$ ).

\subsection{RUNX1-RUNX1T1 AML}

In the RUNX1-RUNX1T1 AML genetic subgroup, statistically significant down-regulation of gene expression was observed for SEPT1 (4.5-fold; $p<0.001$ ), SEPT3 (8.5-fold; $p<0.001$ ), SEPT4 (11.7-fold; $p<0.001$ ), SEPT5 (11.3-fold; $p=0.001$ ), SEPT9 (3.3-fold; $p=0.002$ ), and SEPT10 (9.3-fold; $p<0.001$ ).

\subsection{Normal Karyotype AML}

In this group, the following septin genes showed statistically significant down-regulation: SEPT1 (5.8-fold; $p<0.001)$, SEPT4 (5.3-fold; $p=0.003$ ), SEPT5 (12.8-fold; $p<0.001$ ), SEPT7 (1.7fold; $p=0.001$ ), SEPT9 (5.0-fold; $p<0.001$ ), and SEPT10 (5.7-fold; $p=0.001$ ).

\subsection{AML with MLL-non-septin fusions}

In this genetic subgroup, a statistically significant underexpression was observed for SEPT1 (4.3-fold; $p<0.001$ ), SEPT4 (5.8-fold; $p<0.001$ ), SEPT5 (3.5-fold; $p=0.001$ ), SEPT9 (3.6-fold; $p<0.001$ ), and SEPT10 (3.3-fold; $p<0.001$ ). In addition, downregulation of the combined wild-type $M L L$ and fused-MLL gene expression was observed (1.9-fold; $p=0.023$ ). To evaluate if this down-regulation was due to the large number of MLL-MLLT3 cases (5 out of 10) in this group, the MLL-MLLT3 and the MLL-others group were analyzed and compared separately with the control group. A statistically significant down-regulation of the combined wild-type $M L L$ and fused-MLL gene expression was found in the MLL-MLLT3 group (3.5-fold; $p=0.005$ ) but not in the $M L L$-others group (Fig. 3 ).

\section{Discussion}

We have recently quantified the MLL and SEPT2 gene expression in a series of AML patients selected to represent the major AML genetic subgroups, as well as in all three cases of MLL-SEPT2associated myeloid neoplasia so far described in the literature [15]. In this study, in order to determine the global expression pattern in different AML genetic subtypes of the SEPTIN gene family,

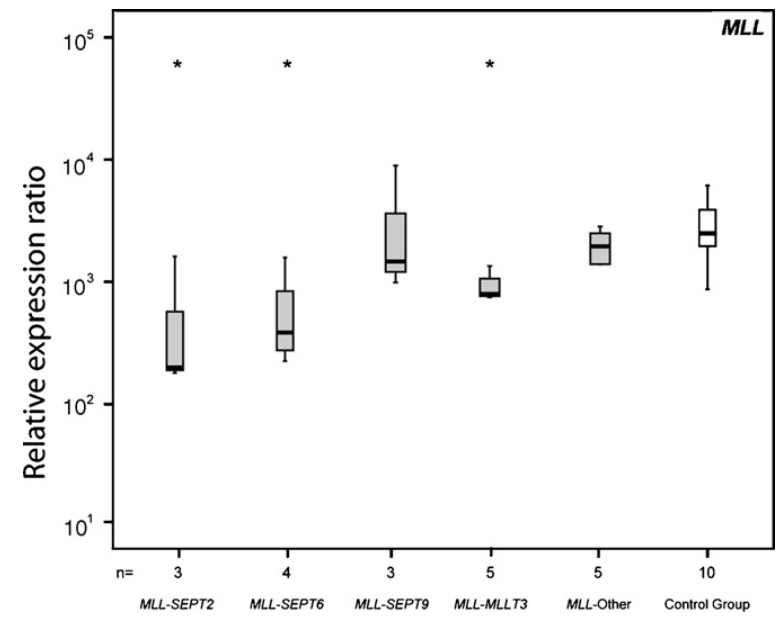

Fig. 3. Box-plot of the normalized expression value for the $M L L$ gene in myeloid neoplasia with MLL-SEPT2, MLL-SEPT6, MLL-SEPT9, MLL-MLLT3, and MLL fused with genes other than $M L L T 3$ or septins. Asterisk denotes significant differences compared to control samples.

whose members are widely expressed in normal human tissues [SEPT2, SEPT4, SEPT6, SEPT8, SEPT9, SEPT10, SEPT11, and (at low levels) SEPT12] [2,23], we characterized the expression level of the remaining 13 human septin genes in the same AML series. We additionally quantified $M L L$ and SEPT6 and SEPT9 gene expression in four cases of MLL-SEPT6 and three cases of MLL-SEPT9-associated AML.

We found a 1.7-fold reduction of wild-type SEPT6 and MLL-SEPT6 combined expression in cases with the MLL-SEPT6 gene fusion, which was accompanied by a 6.4-fold reduction of wild-type $M L L$ and MLL-SEPT6 combined expression (Fig. 2A). These findings show a similar pattern to those previously reported by our group in cases with an MLL-SEPT2 gene fusion, where a 12.8-fold reduction of wild-type SEPT2 and MLL-SEPT2 combined gene expression was also accompanied by down-regulation (12.4-fold) of the wild-type $M L L$ and MLL-SEPT2 combined expression [15]. This may indicate that down-regulation of both $M L L$ and SEPT is a common event in MLLSEPT myeloid neoplasia, but these results should be validated in larger series of patients. SEPT2 and SEPT6 are components of a core septin hexamer complex, which also includes SEPT7, whose formation is thought to be essential to proper cytokinesis. [24]. Indeed, immunological depletion of SEPT2 interferes with cytokinesis [25] and depletion of the SEPT2-SEPT6-SEPT7 complex in HeLa cells leads to loss of polarity and abnormal cell morphology [26], which in turn halts the cell-cycle engine and apoptosis [26]. In addition, correct expression of SEPT2, SEPT6, and SEPT7 seems to be also relevant for the correct functioning of the cell DNA damage checkpoint [26]. These results suggest a connection between abnormalities of septin expression and deregulation of the cell-cycle machinery, a hallmark of human neoplasia. This hypothesis could not be fully corroborated by the analysis of MLL-SEPT9 cases, where no statistically significant down-regulation of MLL and SEPT9 genes was observed, although a tendency toward under-expression of SEPT9 gene was observed. It has been previously shown that SEPT9 is expressed in neutrophils at levels that do not differ from that of myeloid leukaemia, but only a few samples were analyzed [23]. However, depletion by siRNA or by antibody micro-injection of SEPT9 also results in cytokinesis defects [25], adding more support to the hypothesis that the correct expression of SEPT genes in normal cells is a crucial physiologic cell mechanism.

Hierarchical clustering analysis organizes the different AML genetic subtypes and the diverse genes studied in groups based in their similarity level. Based on an analysis of the dendogram 
represented in Fig. 1, we conclude that AML with MLL-SEPT2 or MLL-SEPT6 is distinct from the other AML subgroups analyzed regarding the pattern of septin expression, probably reflecting the observation that SEPT6 and SEPT2 are only under-expressed in the $M L L-S E P T 6$ or MLL-SEPT2 subsets, respectively. An exception to this relationship is the under-expression of SEPT2 in PML-RARA AML. Interestingly, $P M L-R A R A$ AML seems to be clearly distinct from other AML groups regarding septin gene expression abnormalities, since it presents down-regulation of nine different septin genes. The biological meaning of this down-regulation is not known, but it could have something to do with the well known role of the PML-RARA chimeric protein as a potent transcriptional repressor. Interestingly, MLL down-regulation was also observed in the subgroup of $M L L$ fusions with partners other than septin genes. Since the MLL-MLLT3 subset was predominant in this group (five out of 10 cases), we analyzed separately the MLL-MLLT3 and MLL fusions with partners other than septin or MLLT3 and found that the observed $M L L$ down-regulation was restricted to the MLL-MLLT3 subset. This is in agreement with some earlier evidence of $M L L$ down-regulation in AML MLL-MLLT3 patients [27] and supports the hypothesis that $M L L$ down-regulation is a common event in MLL-MLLT3 related leukemia, as it is in AML with the MLL-SEPT2 or MLL-SEPT6 fusion genes. Seemingly, this is in contradiction with the oncogenic role of MLL chimeras in acute leukemia, since a lower quantity of a protein is usually associated with a loss-of-function of tumor suppressor genes [28]. However, chimeric fusion proteins are per se gain of function mutations and even very low levels of aberrant transcription factors may exert their oncogenic potential [29].

Down-regulation of some septin genes seems to be a widespread phenomenon in myeloid neoplasia. For instance, we observed down-regulation of SEPT5 in all AML genetic subgroups studied with the exception of MLL-SEPT9 (Table 1; Fig. 2B). Additionally, when we restrict our analysis to the AML without MLL-SEPT fusions, we observe that SEPT1 and SEPT10 genes are also under-expressed in all subgroups. Also SEPT4 and SEPT9 are under-expressed in all subgroups with the exception CBFB-MYH11 AML. Whereas the septin expression changes we report are novel in AML, the SEPT4 gene was recently shown to be under-expressed in $70 \%$ of infant acute lymphoblastic leukemia (ALL) [30]. The expression of ARTS (an alternative transcript variant of SEPT4 gene) seems to promote apoptosis in response to several pro-apoptotic stimuli such as Fas TGF-b, air-C, etoposide, and STS [30-32]. RNA interference blocking ARTS expression protects cells from TGF-b induced apoptosis [32]. Therefore, our observation of SEPT4 down-regulation in several AML genetic subgroups could indicate a general mechanism of resistance to apoptosis in myeloid leukemogenesis. Accordingly, functional studies of the SEPT4 protein (and also of SEPT1, SEPT5, SEPT9, and SEPT10) could be useful to understand their role in human leukemia and eventually to identify new therapeutic opportunities. On the other hand, expression changes of SEPT8, SEPT11, and SEPT12 do not seem to be frequent in myeloid neoplasia, since they were not found in any of the groups studied. However, we cannot exclude relative expression changes of particular septin isoforms, as we have assessed only their global expression pattern. SEPT14 expression was not detected in any of the AML subgroups studied, which is in agreement with the observation that it is expressed only in testicular tissue [3].

The CBFB-MYH11 subset was the only genetic subgroup showing up-regulation of a septin gene (SEPT6), but its phenotypic impact is currently unknown. Septin up-regulation was previously reported for the SEPT9 gene in other neoplasias, with over-expression of one or more SEPT9 isoforms being associated with breast, ovarian, and prostate cancer $[23,33-38]$. A recent study showed that SEPT9_v1 over-expression was associated with accelerated growth kinetics, cell motility, invasion, genomic instability and morphologic changes in human breast cells [38].
In conclusion, we demonstrated significant down-regulation of SEPT6 and MLL in MLL-SEPT6 AML, like we had previously shown for MLL and SEPT2 in MLL-SEPT2 myeloid neoplasia. Significant MLL down-regulation was also observed in MLL-MLLT3 AML and a trend toward SEPT9 under-expression was seen in MLL-SEPT9 AML. We have further shown that septin expression changes are common in myeloid neoplasia; the mechanisms and biological significance of this observation deserve further study.

\section{Conflict of interest statement}

None.

\section{Acknowledgments}

This research was supported by grants from the "Associação Portuguesa Contra a Leucemia" (2006-30.2.AP/MJ) and the "Comissão de Fomento da Investigação em Cuidados de Saúde” (P.I. 26/2007).

Contributions. JS and NC designed and performed the research, analyzed the data and wrote the manuscript. SB performed RT-PCR studies. FRR analyzed the data. SL, CC, LT, and JV performed the chromosome banding and molecular cytogenetic studies. JMM and LN clinically assessed the patients. SS, CHM, and AB characterized patients 59 and 60 and provided samples of both patients for RTPCR and qRT-PCR studies. S L-Y characterized patients 62 and 66 and provided samples of both patients for RT-PCR and qRT-PCR studies. SS characterized patient 65 and provided a sample for RTPCR and qRT-PCR studies. FM and SH characterized patients 63 and 64 and provided samples of both patients for RT-PCR and qRT-PCR studies. MRT coordinated the study and participated in manuscript writing. All authors read and approved the final manuscript.

\section{Appendix A. Supplementary data}

Supplementary data associated with this article can be found, in the online version, at doi:10.1016/j.leukres.2009.08.018.

\section{References}

[1] Hall PA, Russell SE. The pathobiology of the septin gene family. J Pathol 2004;204:489-505.

[2] Hall PA, Jung K, Hillan KJ, Russell SE. Expression profiling the human septin gene family. J Pathol 2005;206:269-78.

[3] Peterson EA, Kalikin LM, Steels JD, Estey MP, Trimble WS, Petty EM. Characterization of a SEPT9 interacting protein, SEPT14, a novel testis-specific septin. Mamm Genome 2007;18:796-807.

[4] Cerveira N, Correia C, Bizarro S, Pinto C, Lisboa S, Mariz JM, et al. SEPT2 is a new fusion partner of MLL in acute myeloid leukemia with $\mathrm{t}(2 ; 11)(\mathrm{q} 37 ; \mathrm{q} 23)$. Oncogene 2006:25:6147-52.

[5] Meyer C, Schneider B, Jakob S, Strehl S, Attarbaschi A, Schnittger S, et al. The MLL recombinome of acute leukemias. Leukemia 2006;20:777-84.

[6] Russell SE, Hall PA. Do septins have a role in cancer? $\mathrm{Br}$ J Cancer 2005;93:499-503.

[7] Megonigal MD, Rappaport EF, Jones DH, Williams TM, Lovett BD, Kelly KM, et al. $\mathrm{t}(11 ; 22)(\mathrm{q} 23 ; \mathrm{q} 11.2)$ in acute myeloid leukemia of infant twins fuses MLL with hCDCrel, a cell division cycle gene in the genomic region of deletion in DiGeorge and velocardiofacial syndromes. Proc Natl Acad Sci USA 1998;95:6413-8.

[8] Ono R, Taki T, Taketani T, Kawaguchi H, Taniwaki M, Okamura T, et al. SEPTIN6, a human homologue to mouse Septin6, is fused to MLL in infant acute myeloid leukemia with complex chromosomal abnormalities involving $11 \mathrm{q} 23$ and Xq24. Cancer Res 2002;62:333-7.

[9] Osaka M, Rowley JD, Zeleznik-Le NJ. MSF (MLL septin-like fusion), a fusion partner gene of MLL, in a therapy-related acute myeloid leukemia with a $\mathrm{t}(11 ; 17)(\mathrm{q} 23 ; \mathrm{q} 25)$. Proc Natl Acad Sci USA 1999;96:6428-33.

[10] Taki T, Ohnishi H, Shinohara K, Sako M, Bessho F, Yanagisawa M, et al. AF17q25, a putative septin family gene, fuses the MLL gene in acute myeloid leulemia with $\mathrm{t}(11 ; 17)(\mathrm{q} 23 ; \mathrm{q} 25)$. Cancer Res 1999;59:4261-5.

[11] Kojima K, Sakai I, Hasegawa A, Niiya H, Azuma T, Matsuo Y, et al. FLJ10849, a septin family gene, fuses MLL in a novel leukemia cell line CNLBC1 derived from chronic neutrophilic leukemia in transformation with $\mathrm{t}(4 ; 11)(\mathrm{q} 21 ; \mathrm{q} 23)$. Leukemia 2004;18:998-1005.

[12] Krivtsov AV, Armstrong SA. MLL translocations, histone modifications and leukaemia stem-cell development. Nat Rev Cancer 2007;7:823-33. 
[13] Cerveira N, Santos J, Pinheiro M, Snijder S, van der Lelie H, Mellink CH, et al. A novel MLL-SEPT2 fusion variant in therapy-related myelodysplastic syndrome. Cancer Genet Cytogenet 2008;185:62-4.

[14] Cerveira N, Micci F, Santos J, Pinheiro M, Correia C, Lisboa S, et al. Molecular characterization of the MLL-SEPT6 fusion gene in acute myeloid leukemia: identification of novel fusion transcripts and cloning of genomic breakpoint junctions. Haematologica 2008;93:1076-80.

[15] Cerveira N, Santos J, Bizarro S, Costa V, Ribeiro FR, Lisboa S, et al. Both SEPT2 and $M L L$ are down-regulated in $M L L-S E P T 2$ therapy-related acute myeloid leukemia. BMC Cancer 2009;9:147.

[16] van Binsbergen E, de Weerdt O, Buijs A. A new subtype of MLL-SEPT2 fusion transcript in therapy-related acute myeloid leukemia with $\mathrm{t}(2 ; 11)(\mathrm{q} 37 ; \mathrm{q} 23)$ : a case report and literature review. Cancer Genet Cytogenet 2007;176: $72-5$.

[17] Snijder S, Mellink CH, van der Lelie H. Translocation (2;11)(q37;q23) in therapyrelated myelodysplastic syndrome after treatment for acute promyelocytic leukemia. Cancer Genet Cytogenet 2008;180:149-52.

[18] Fu JF, Liang DC, Yang CP, Hsu JJ, Shih LY. Molecular analysis of $t(X ; 11)(q 24 ; q 23)$ in an infant with AML-M4. Genes Chromosomes Cancer 2003:38:253-9.

[19] Shih LY, Liang DC, Fu JF, Wu JH, Wang PN, Lin TL, et al. Characterization of fusion partner genes in 114 patients with de novo acute myeloid leukemia and MLL rearrangement. Leukemia 2006;20:218-23.

[20] Strehl S, König M, Meyer C, Schneider B, Harbott J, Jäger U, et al. Molecular dissection of $\mathrm{t}(11 ; 17)$ in acute myeloid leukemia reveals a variety of gene fusions with heterogeneous fusion transcripts and multiple splice variants. Genes Chromosomes Cancer 2006;45:1041-9.

[21] Gabert J, Beillard E, van der Velden VH, Bi W, Grimwade D, Pallisgaard N, et al. Standardization and quality control studies of 'real-time' quantitative reverse transcriptase polymerase chain reaction of fusion gene transcripts for residual disease detection in leukemia - a Europe Against Cancer program. Leukemia 2003; $17: 2318-57$

[22] Beillard E, Pallisgaard N, van der Velden VH, Bi W, Dee R, van der Schoot $\mathrm{E}$, et al. Evaluation of candidate control genes for diagnosis and residual disease detection in leukemic patients using 'real-time' quantitative reversetranscriptase polymerase chain reaction (RQ-PCR) - a Europe against cancer program. Leukemia 2003;17:2474-86.

[23] Scott M, Hyland PL, McGregor G, Hillan KJ, Russell SE, Hall PA. Multimodality expression profiling shows SEPT9 to be overexpressed in a wide range of human tumors. Oncogene 2005;24:4688-700.

[24] Weirich CS, Erzberger JP, Barral Y. The septin family of GTPases: architecture and dynamics. Nat Rev Mol Cell Biol 2008;9:478-89.
[25] Kinoshita M, Field CM, Coughlin ML, Straight AF, Mitchison TJ. Self- and actintemplated assembly of Mammalian septins. Dev Cell 2002;3:791-802.

[26] Kremer BE, Haystead T, Macara IG. Mammalian septins regulate microtubule stability through interaction with the microtubule-binding protein MAP4. Mol Biol Cell 2005; 16:4648-59.

[27] Whitmann SP, Liu S, Vukosavljevic T, Rush LJ, Liu C, Klisovic MI, et al. The MLL partial tandem duplication: evidence for recessive gain-of-function in acute partial tandem duplication: evidence for recessive gain-of-function in acute
myeloid leukemia identifies a novel patient subgroup for molecular-targeted therapy. Blood 2005;106:345-52.

[28] Wong JC, Le Beau MM, Shannon K. Tumor suppressor gene inactivation in myeloid malignancies. Best Pract Res Clin Haematol 2008;21:601-14.

[29] Raj A, van Oudenaarden A. Nature, nurture, or chance: stochastic gene expression and its consequences. Cell 2008;135:216-26.

[30] Elhasid R, Sahar D, Merling A, Zivony Y, Rotem A, Ben-Arush M, et al. Mitochondrial pro-apoptotic ARTS protein is lost in the majority of acute lymphoblastic leukemia patients. Oncogene 2004;23:5468-75.

[31] Gottfried Y, Rotem A, Lotan R, Steller H, Larisch S. The mitochondrial ARTS protein promotes apoptosis through targeting XIAP. EMBO J 2004;23: 1627-35.

[32] Larisch S, Yi Y, Lotan R, Kerner H, Eimerl S, Tony Parks W, et al. A novel mitochondrial septin-like protein, ARTS, mediates apoptosis dependent on its P-loop motif. Nat Cell Biol 2000;2:915-21.

[33] Kalikin LM, Sims HL, Petty EM. Genomic and expression analyses of alternatively spliced transcripts of the MLL septin-like fusion gene (MSF) that map to a $17 \mathrm{q} 25$ region of loss in breast and ovarian tumors. Genomics 2000;63: 165-72.

[34] Montagna C, Lyu MS, Hunter K, Lukes L, Lowther W, Reppert T, et al. The Septin 9 (MSF) gene is amplified and overexpressed in mouse mammary gland adenocarcinomas and human breast cancer cell lines. Cancer Res 2003;63:2179-87.

[35] Scott M, McCluggage WG, Hillan KJ, Hall PA, Russell SE. Altered patterns of transcription of the septin gene, SEPT9, in ovarian tumorigenesis. Int J Cancer transcription of the

[36] Gonzalez ME, Peterson EA, Privette LM, Loffreda-Wren JL, Kalikin LM, Petty EM. High SEPT9_v1 expression in human breast cancer cells is associated with oncogenic phenotypes. Cancer Res 2007;67:8554-64.

[37] Gladfelter AS, Montagna C. Seeking truth on Monte Verita. Workshop on the molecular biology and biochemistry of septins and septin function. EMBO Rep 2007;8:1120-6.

[38] Burrows JF, Chanduloy S, Mcllhatton MA, Nagar H, Yeates K, Donaghy P, et al. Altered expression of the septin gene, SEPT9, in ovarian neoplasia. J Pathol 2003;201:581-8. 


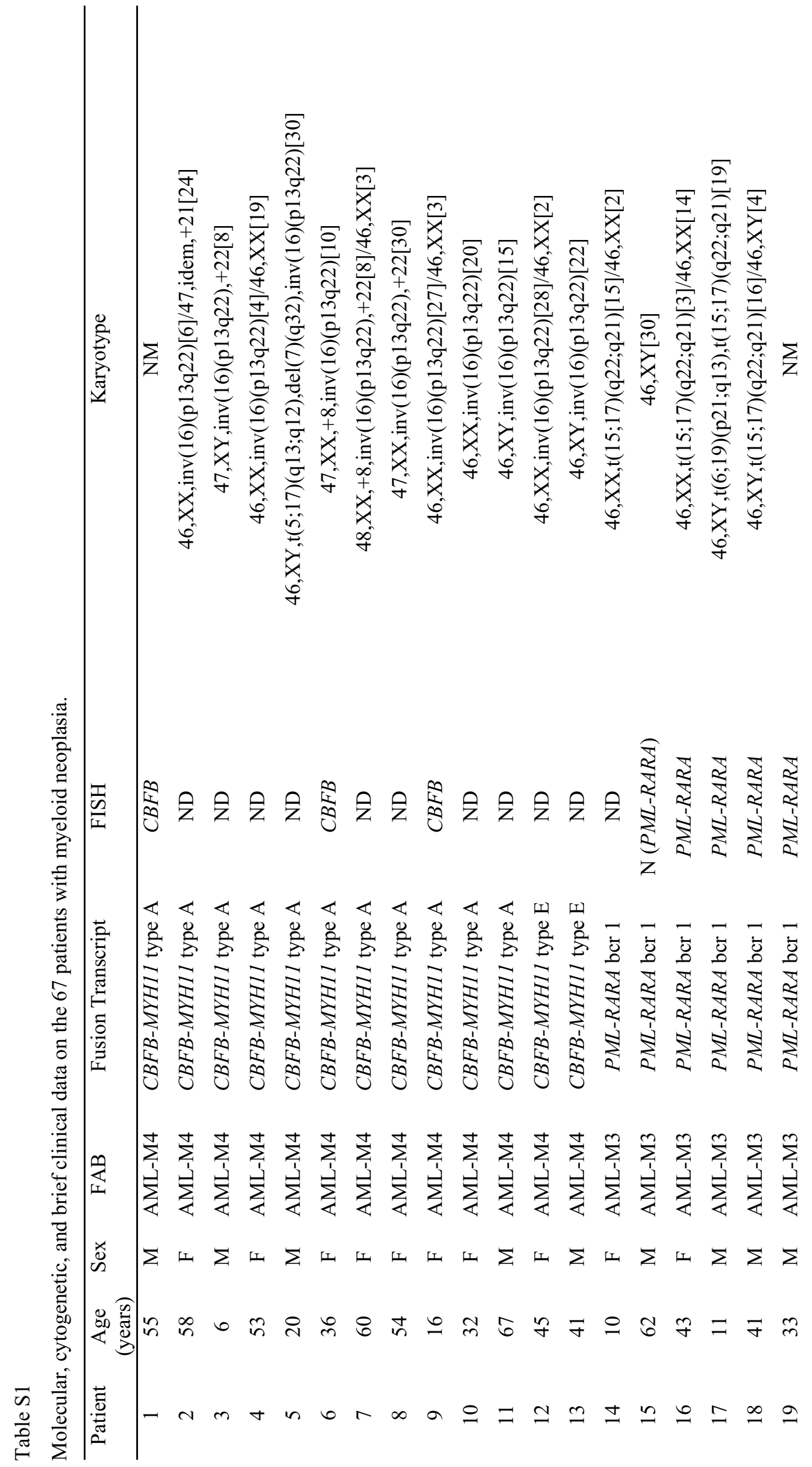




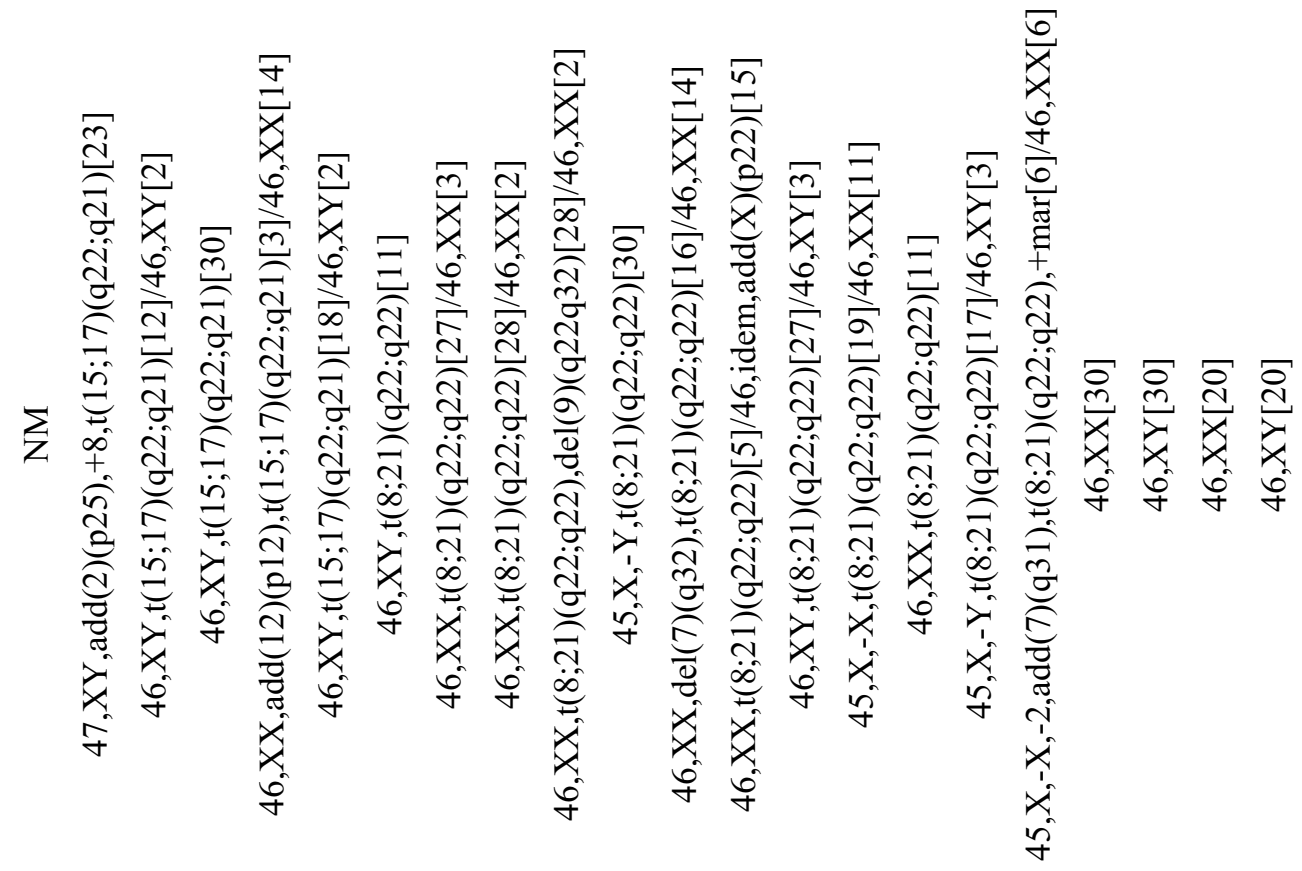

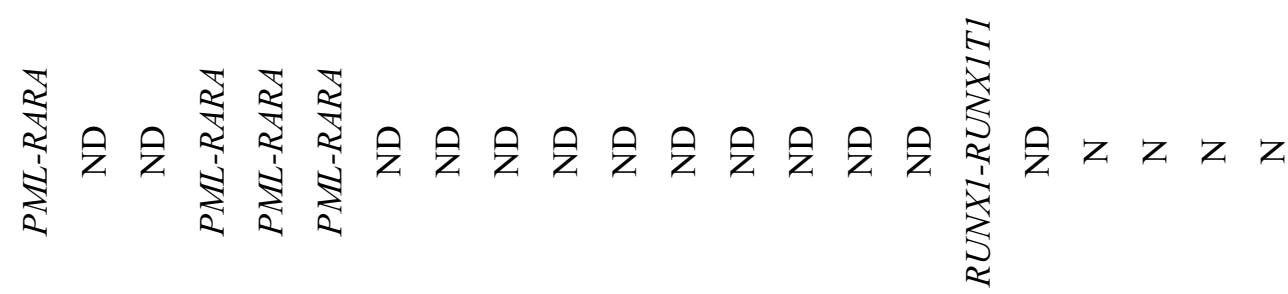

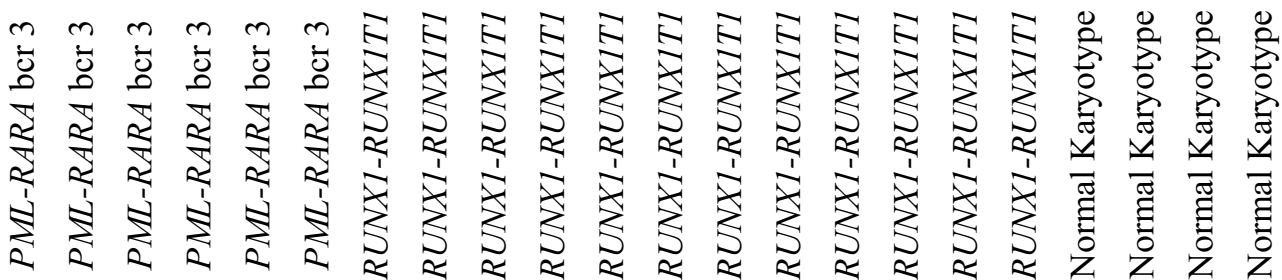

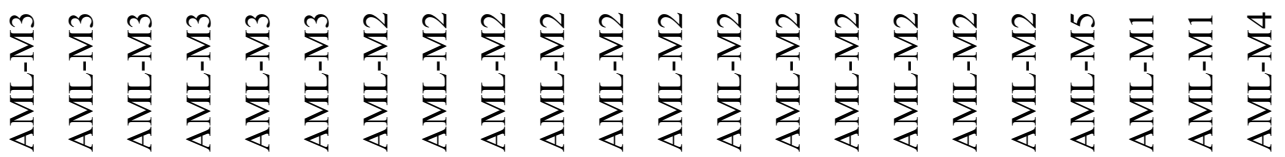

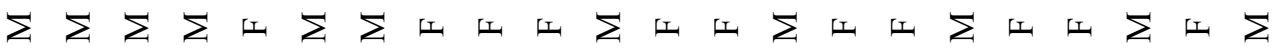

ชิ ลิ ลิ

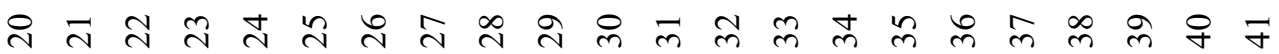




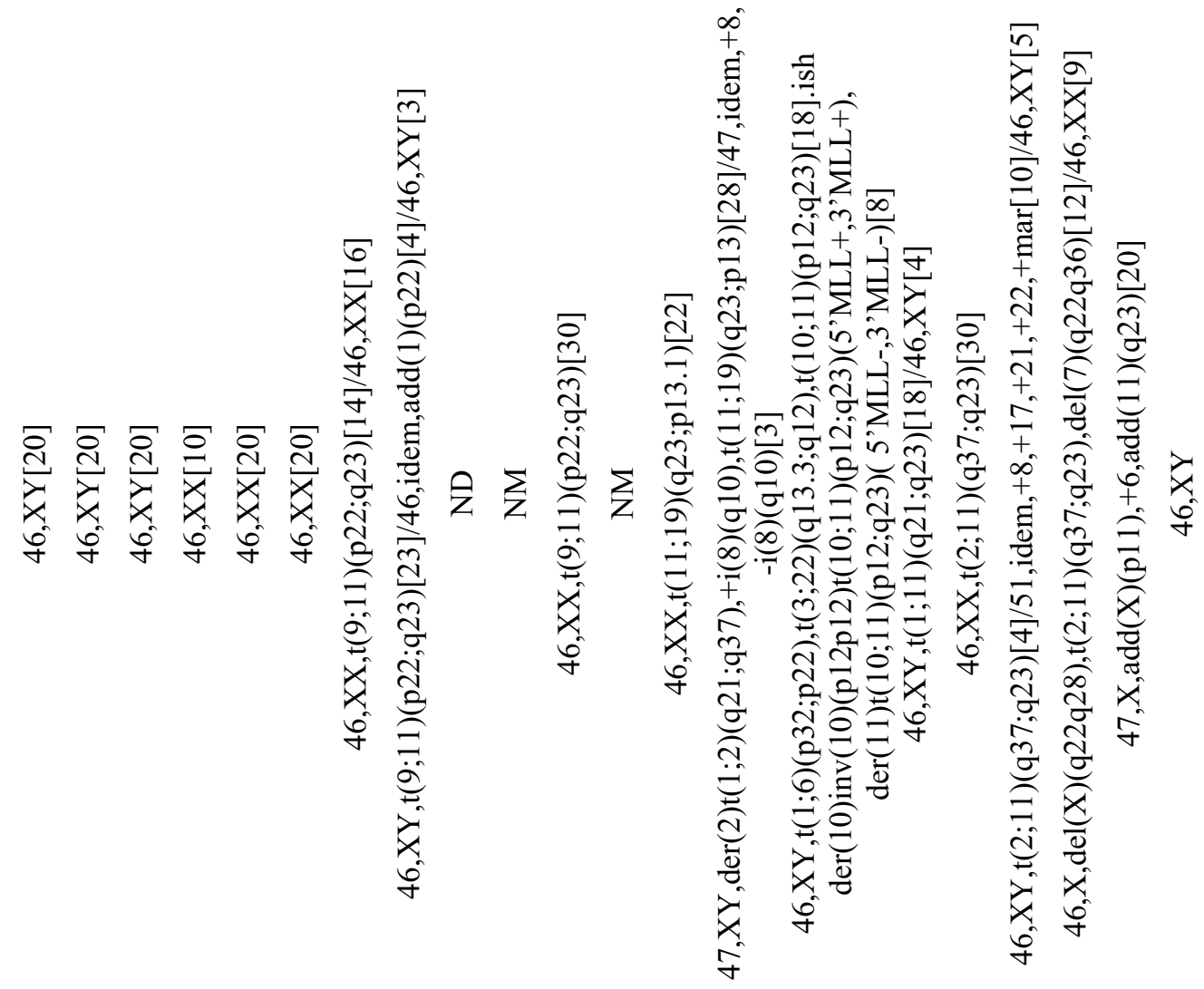

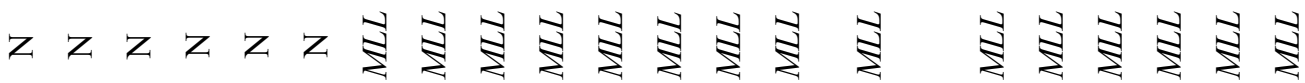

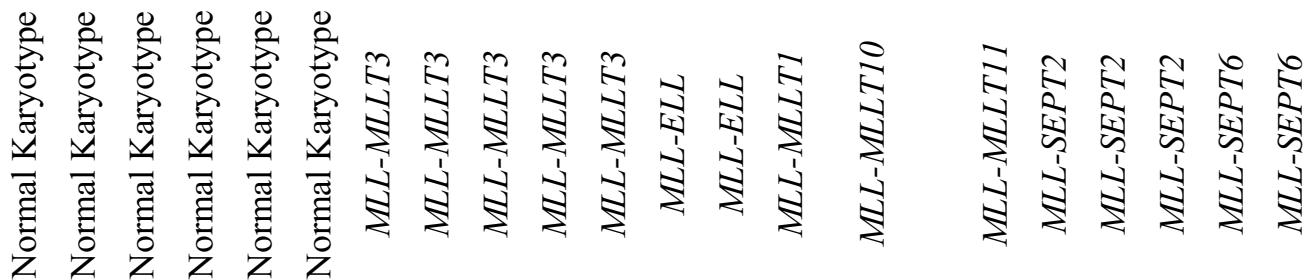

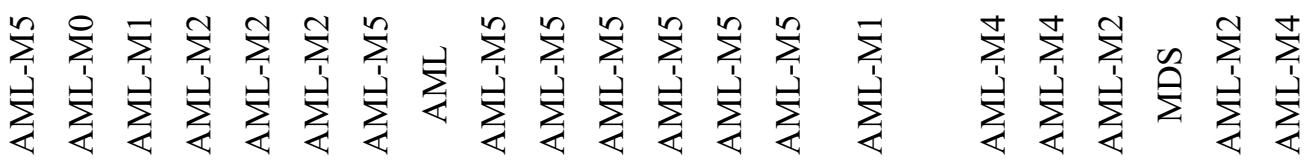

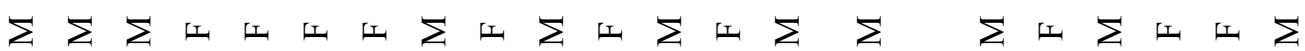

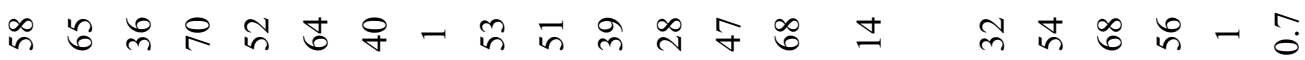

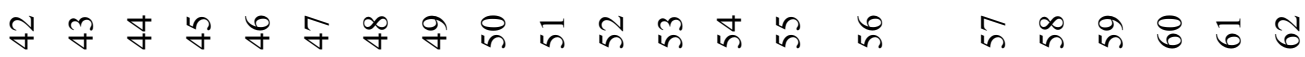




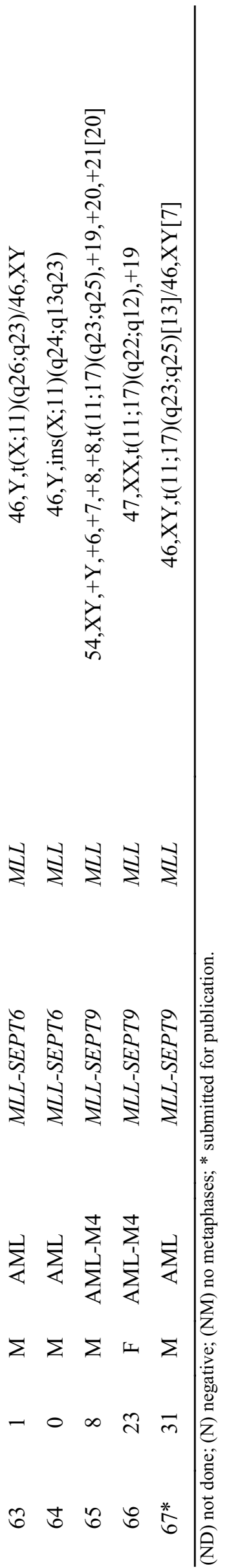


Table S2 Oligonucleotide primers and probes (5'FAM, 3'TAMRA) used in this study.

\begin{tabular}{|c|c|c|c|c|}
\hline Gene & Exon & Position & Primer/Probe & Sequence 5'-3' \\
\hline \multirow[t]{3}{*}{$A B L 1$} & 2 & 225255 & ABL1-S & $\begin{array}{l}\text { TGGAGATAACACTCTAAGCATAACTAAAGGT } \\
\end{array}$ \\
\hline & 3 & 293320 & ABL1-PR & CCATTTTTGGTTTGGGCTTCACACCATT \\
\hline & 3 & $328-348$ & ABL1-AS & GATGTAGTTGCTTGGGACCCA \\
\hline \multirow[t]{3}{*}{ MLL } & 4 & $3313-3336$ & MLL-S & CATGGGAAGAACGAGAAAAGATTT \\
\hline & 5 & 3358 -3382 & MLL-PR & ACAAGTCATCAATTGCTGGCTCAGA \\
\hline & 5 & 33853405 & MLL-AS & GTGGAGCAAGAGGTTCAGCAT \\
\hline \multirow[t]{3}{*}{ SEPT1 } & 3 & $253^{-} 275$ & SEPT1-S & GGGTTTGACTTCACGCTAATGG \\
\hline & 4 & $284 \_311$ & SEPT1-PR & AGTCAGGCCTAGGGAAATCCACCCTCA \\
\hline & 4 & $312^{-} 333$ & SEPT1-AS & TTGGTGAGGAAGAGGCTGTTG \\
\hline \multirow[t]{3}{*}{ SEPT2 } & 3 & $161_{-183}^{-1}$ & SEPT2-S & CACCGAAAATCAGTGAAAAAAGG \\
\hline & 3 & 186212 & SEPT2-PR & TTGAGTTCACACTGATGGTGGTCGGTG \\
\hline & 4 & $223-247$ & SEPT2-AS & GCTGTTTATGAGAGTCGATTTTCCT \\
\hline \multirow[t]{3}{*}{ SEPT3 } & 2 & $301-323$ & SEPT3-S & GACCGGTTTCGACTTCAACATC \\
\hline & 2 & $324-344$ & SEPT3-PR & TGGTCGTTGGCCAGAGTGGA \\
\hline & 3 & $351 \_371$ & SEPT3-AS & CGTGTTGACCAGCGTTGATT \\
\hline \multirow[t]{3}{*}{ SEPT4 } & 5 & 667689 & SEPT4-S & GGGATGCAGTCAACAACACAGA \\
\hline & 5 & $690^{-} 717$ & SEPT4-PR & TGCTGGAAGCCTGTGGCAGAATACATT \\
\hline & 6 & $726_{-}^{-} 748$ & SEPT4-AS & CGTCTCGGAAATACTGCTCAAA \\
\hline \multirow[t]{3}{*}{ SEPT5 } & 6 & $715^{-} 737$ & SEPT5-S & CTGACTGTCTTGTCCCCAGTGA \\
\hline & 6 & 738762 & SEPT5-PR & ATCCGGAAGCTGAAGGAGCGGATC \\
\hline & 7 & $768^{-} 791$ & SEPT5-AS & TGGATCCCAAACTTGTCAATCTC \\
\hline \multirow[t]{3}{*}{ SEPT6 } & 2 & $377^{-} 395$ & SEPT6-S & GCCAGGGCTTCTGCTTCA \\
\hline & 2 & $396-418$ & SEPT6-PR & CATCCTGTGCGTGGGAGAGACA \\
\hline & 3 & $419-438$ & SEPT6-AS & AGGGTGGACTTGCCCAAAC \\
\hline \multirow[t]{3}{*}{ SEPT7 } & 5 & $466^{-} 493$ & SEPT7-S & TGTTGTTTATACTTCATTGCTCCTTCA \\
\hline & 5 & $495^{-} 523$ & SEPT7-PR & ACATGGACTTAAACCATTGGATATTGAG \\
\hline & 6 & $526-548$ & SEPT7-AS & СТTTTTCATGCAAACGCTTCAT \\
\hline \multirow[t]{3}{*}{ SEPT8 } & 5 & $896-916$ & SEPT8-S & AGTTCCCCACGGATGATGAG \\
\hline & 5 & 918943 & SEPT8-PR & TGTTGCAGAGATTAACGCAGTCATG \\
\hline & 6 & $944^{-} 963$ & SEPT8-AS & GCAAAGGGCAGATGTGCAT \\
\hline \multirow[t]{3}{*}{ SEPT9 } & 4 & $1768_{-}^{-} 1790$ & SEPT9-S & CCATCGAGATCAAGTCCATCAC \\
\hline & 5 & $1793^{-} 1818$ & SEPT9-PR & TGTGTCAATCACTGTCAGCTTCA \\
\hline & 5 & 18191842 & SEPT9-AS & CGATATTGAGGAGAAAGGCGTCCGG \\
\hline \multirow[t]{3}{*}{ SEPT10 } & 4 & $373^{-} 394$ & SEPT10-S & CAGTGGGATTTGGTGACCAAA \\
\hline & 4 & $395^{-} 429$ & SEPT10-PR & AAATAAAGAAGAGAGCTACCAACCAATAGTTGAC \\
\hline & 5 & $430-453$ & SEPT10-AS & GGCCTCAAACTGAGCATCTATGT \\
\hline \multirow[t]{3}{*}{ SEPT11 } & 4 & 648668 & SEPT11-S & TCCCTGGATCTGGTCACCAT \\
\hline & 4 & 669688 & SEPT11-PR & AAAAAGCTGGACAGTAAGG \\
\hline & 5 & $689^{-} 715$ & SEPT11-AS & CTTTTGCAATTATTGGAATGATGTTC \\
\hline \multirow[t]{3}{*}{ SEPT12 } & 7 & $769^{-} 790$ & SEPT12-S & TGTGCTTTGACGAGGACATCA \\
\hline & 7 & $791-818$ & SEPT12-PR & TGACAAAATCCTCAACAGCAAGTTACG \\
\hline & 8 & 822840 & SEPT12-AS & CACGGCAAAAGGGATTCG \\
\hline \multirow[t]{3}{*}{ SEPT13 } & 3 & $318+344$ & SEPT13-S & AGGGTGCACTGTTGTTTATACTTCAT \\
\hline & 3 & 352378 & SEPT13-PR & CAGGACATGGACTTAAACCATTGGAT \\
\hline & 4 & $379-403$ & SEPT13-AS & CATGCAAATGCTTTGTAAACTCAA \\
\hline \multirow[t]{3}{*}{ SEPT14 } & 2 & $288_{-}^{-} 314$ & SEPT14-S & GGGTATGGTGATCAAATAGACAAAGA \\
\hline & 2 & 316331 & SEPT14-PR & CCAGCTACCAACCAA \\
\hline & 3 & 332358 & SEPT14-AS & CAAATTGGGCATCTATGTAGTCAACT \\
\hline
\end{tabular}

The GenBank accession numbers for the genes studied are: ABL1 (NM_007313), MLL (NM_005933), SEPT1 (NM 052838), SEPT2 (NM 006155), SEPT3 (NM 145734), SEPT4 (NM 080417), SEPT5 (NM 002688), SEPT6 (NM_145802), SEPT7 (NM_001788), SEPT8 (XM_034872), SEPT9 (NM_006640), SEPT10 (NM 144710), SEPT11 (NM 018243), SEPT12 (NM_144605), SEPT13 (AL133216), and SEPT14 (NM_207366). (S) sense; (AS) anti-sense; (PR) probe. 


\section{GLOBAL DISCUSSION, CONCLUSIONS AND} FUTURE PERSPECTIVES 
GLOBAL DISCUSSION, CONCLUSIONS AND FUTURE PERSPECTIVES 


\section{PAPER \#7}

Nuno Cerveira, Joana Santos, Manuel R. Teixeira

\section{STRUCTURAL AND EXPRESSION CHANGES OF SEPTIN IN} MYELOID NEOPLASIA

Crit Rev Oncog, 15: 91-115, 2009 
GLOBAL DISCUSSION, CONCLUSIONS AND FUTURE PERSPECTIVES 


\title{
Structural and Expression Changes of Septins in Myeloid Neoplasia
}

\author{
Nuno Cerveira ${ }^{1}$, Joana Santos ${ }^{l}$, \& Manuel R. Teixeira ${ }^{1,2}$ \\ ${ }^{1}$ Department of Genetics, Portuguese Oncology Institute, Porto, Portugal; ${ }^{2}$ Abel Salazar Biomedical \\ Sciences Institute (ICBAS), Porto, Portugal \\ Address correspondence to Manuel R. Teixeira, Department of Genetics, Portuguese Oncology In- \\ stitute, Rua Dr. António Bernardino de Almeida, 4200-072 Porto, Portugal; Phone: +351 225084000; \\ Fax: +351 225084016; manuel.teixeira@ipoporto.min-saude.pt
}

\begin{abstract}
Septins are an evolutionarily conserved family of GTP-binding proteins that associate with cellular membranes and the actin and microtubule cytoskeletons. Fourteen septin genes have been characterized to date (SEPT1 to SEPT14) in humans. Septins have been reported to be misregulated in various human diseases, including neurological disorders, infection, and neoplasia. In this review, we describe what is known thus far about septin deregulation in myeloid neoplasia. Septin abnormalities in myeloid neoplasia can be divided into two major groups. First, some septins (SEPT2, SEPT5, SEPT6, SEPT9, and SEPT11) have been repeatedly identified as in-frame fusion partners of the $M L L$ gene in de novo and therapy-related myeloid neoplasia, in both children and adults. Second, deregulation of the expression of septin family genes in hematological cancers can be observed either with or without the concomitant presence of MLL gene fusions. Although current hypotheses regarding the roles of septins in oncogenesis remain speculative for the most part, the fundamental roles of septins in cytokinesis, membrane remodeling, and compartmentalization can provide some clues on how abnormalities in the septin cytoskeleton could be involved in neoplastic disorders.
\end{abstract}

KEY WORDS: septins, myeloid neoplasia, fusion gene

\section{INTRODUCTION}

Septins are an evolutionarily conserved family of GTP-binding proteins that associate with cellular membranes and the actin and microtubule cytoskeletons. ${ }^{1}$ The founding members $C d c 3, C d c 10, C d c 11$, and $C d c 12$ were discovered 35 years ago in Saccharomyces cerevisiae budding mutants that were defective in cytokinesis and cell morphology, and were named septins on the basis of their function in cytokinesis and localization to the mother-bud neck. ${ }^{2}$ Despite the mechanistic differences between budding yeast and dividing animal cells, homologs in Caenorhabditis elegans, Drosophila melanogaster, and mammals have subsequently been identified. ${ }^{2-4}$ 
N. Cerveira, J. Santos, \& M.R. Teixeira

\section{SEPTIN STRUCTURE AND FUNCTION}

Fourteen septin genes have been characterized to date (SEPT1 to SEPT14) in humans. ${ }^{4-7}$ These genes map throughout the human genome, are strikingly similar, and all possess a P loop-based GTP-binding (G) domain flanked by a polybasic domain and, with a few exceptions, a $\mathrm{C}$-terminal coiled-coil region (SEPT1, 2, 4-8, 10, 11, 13, and 14) and/or a long N-terminal extension rich in proline residues (SEPT4, 8, and 9) (Table 1).$^{5-7}$ Many septins possess additional extensions at their $\mathrm{N}$ and $\mathrm{C}$ termini, which are predicted to be disordered. ${ }^{8}$

Septins belong to the GTPase superclass of P-loop NTPases, which includes the Ras-type superfamily of small GTPases, translation factors, the OBG/ HflX superfamily, and the structurally related myosin-kinesin superfamily of ATPases. ${ }^{5}$ Similar to yeast septins, animal septins can bind and hydrolyze GTP, and can also form polymeric actin-associated filamentous structures that act as diffusion barriers between different membrane domains and as molecular scaffolds for membrane- and cytoskeleton-binding proteins. ${ }^{1}$ The function of the GTP-binding domain has not been fully elucidated, but there is some evidence that it may have GTPase signaling properties or structural properties associated with oligomerization between septins or between septins and other proteins. ${ }^{5,9}$ The polybasic domain has been implicated in the binding of phosphoinositol phosphates and in membrane dynamics. ${ }^{1,4}$ All septin transcripts contain multiple translation initiation sites and are alternatively spliced, giving origin to multiple septin isoforms, some of which are tissue specific. ${ }^{1}$ With the exception of SEPT14, which has its expression restricted to the normal testis, septins are expressed in all tissue types but some show high expression in lymphoid (SEPT1, 6, 9, and 12) or brain tissues (SEPT2, $3,4,5,7,8$, and 11) (Table 1). ${ }^{7,10}$

Individual septins form small core complexes both in vivo and in vitro that, in humans, contain three septins, each present in two copies. ${ }^{11-13}$ The characterization of the crystal structure of the first septin complex, the human SEPT2-SEPT6-SEPT7 complex, showed that it assembles into a hexamer composed of two copies of each septin protein, with SEPT6 sandwiched between SEPT2 and SEPT7, and that complex and filament formation is dependent on the GTPase domains rather than, as had been previously proposed, on the coiled-coil domains. ${ }^{8,11,14}$

Septins have been reported to be misregulated in various human diseases, including neurological disorders, infection, and neoplasia, with recent studies raising the hypothesis that septins might have oncogenic function of their own or, at least, that they are sensitive to imbalances in cell physiology that are characteristic of cancer. Septin abnormalities in human cancer can be classified into two distinct groups: septin gene fusions with the $M L L$ gene and septin gene expression changes. ${ }^{15-29}$ 
TABLE 1. Genetic and Protein Data of the Human Septin Family

\begin{tabular}{lcccc}
\hline $\begin{array}{l}\text { Septin } \\
\text { Gene }\end{array}$ & $\begin{array}{c}\text { Chromosomal } \\
\text { Location }\end{array}$ & $\begin{array}{c}\text { Coiled-Coil } \\
\text { Region }\end{array}$ & $\begin{array}{c}\text { Proline-rich } \\
\text { Domain }\end{array}$ & $\begin{array}{c}\text { Expression } \\
\text { Pattern }\end{array}$ \\
\hline SEPT1 & $16 \mathrm{p} 11.2$ & Yes & No & All tissues* $^{*}$ \\
SEPT2 & $2 \mathrm{q} 37.3$ & Yes & No & All tissues $^{* *}$ \\
SEPT3 & $22 \mathrm{q} 13.2$ & No & No & All tissues $^{* *}$ \\
SEPT4 & $17 \mathrm{q} 22$ & Yes & Yes & All tissues $^{* *}$ \\
SEPT5 & $22 \mathrm{q} 11.21$ & Yes & No & All tissues $^{* *}$ \\
SEPT6 & Xq24 & Yes & No & All tissues* $^{*}$ \\
SEPT7 & $7 \mathrm{p} 14.2$ & Yes & No & All tissues $^{* *}$ \\
SEPT8 & $5 \mathrm{q} 31.1$ & Yes & Yes & All tissues $^{* *}$ \\
SEPT9 & $17 \mathrm{q} 25.3$ & No & Yes & All tissues* $^{*}$ \\
SEPT10 & $2 \mathrm{q} 13$ & Yes & No & All tissues \\
SEPT11 & $4 \mathrm{q} 21.1$ & Yes & No & All tissues \\
SEPT12 & $16 \mathrm{p} 13.3$ & No & No & All tissues* \\
SEPT13 & $7 \mathrm{p} 12.3$ & Yes & No & All tissues \\
SEPT14 & $7 \mathrm{p} 11.2$ & Yes & No & Testis \\
\hline
\end{tabular}

In addition to the protein domains described in the table, all known septins present a polybasic domain and a GTP-binding domain (see text for details).

*Higher expression in lymphoid tissues; ${ }^{* *}$ Higher expression in brain tissues. See references $5-10$.

\section{SEPTINS AS MLL FUSION PARTNERS}

The first clues to the role of septins in myeloid neoplasia came from the observation that balanced translocations involving septin loci and the $M L L$ gene on chromosome 11q23 occurred in leukemia, giving rise to chimeric fusion proteins in which the $\mathrm{N}$ terminus of MLL was fused, in frame, to almost the entire open reading frame of the septin partner gene (Table 2; Figs. 1 and 2). ${ }^{15-20}$ The first septin identified as a $M L L$ fusion partner was SEPT9 and, subsequently, it has been found that four other septins (SEPT2, SEPT5, SEPT6, and SEPT11) can form very similar fusion proteins with MLL (Fig. 2). ${ }^{15-20}$ The rearranged alleles show heterogeneous breaks in introns of both $M L L$ and its septin fusion partner, which result in distinct fusion variants (Table 2; Figure 2). Although patients with different subtypes of $M L L$ fusion variants are not believed to differ significantly regarding biological and clinical parameters, their identification and detailed characterization 
N. Cerveira, J. Santos, \& M.R. Teixeira

is essential for accurate molecular subtyping at diagnosis and subsequent patient follow-up. The $M L L$ gene codes for a multi-domain molecule that, through methylation and acetylation, is a major regulator of class I homeobox (HOX) gene expression (Fig. 3). ${ }^{49}$ Abnormalities of 11q23 involving the $M L L$ gene are found in acute lymphoblastic leukemia (ALL) and acute myeloid leukemia (AML), in the latter mostly in the French-American-British (FAB) subtypes M4 and M5. ${ }^{50-52}$ To date, 71 different chromosome bands have been described in rearrangements involving $11 \mathrm{q} 23$, and approximately 50 fusion genes have been cloned. ${ }^{50}$ It is generally accepted that the deregulation of the MLL protein function is the key event in MLL-mediated leukemogenesis.

\section{A. The MLL-SEPT2 Gene Fusion}

Our group has established the MLL-SEPT2 gene fusion as the molecular abnormality subjacent to the translocation $\mathrm{t}(2 ; 11)(\mathrm{q} 37 ; \mathrm{q} 23)$, in a case of therapy-related acute myeloid leukemia (t-AML) of the M4 FAB subtype (Table 2).$^{20}$ The molecular characterization of the fusion transcript showed a fusion of $M L L$ exon 10 (or exon 7, depending of the published exon nomenclature used) ${ }^{46-48}$ with SEPT2 exon 3 (type I fusion transcript) (Fig. 2). ${ }^{20}$ A second $M L L-S E P T 2$ fusion variant involving $M L L$ exon 9 (6) with SEPT2 exon 3 (type II fusion transcript) was identified in a patient with t-AML of the M2 FAB subtype. ${ }^{30}$ We recently uncovered a third MLL-SEPT2 alternative fusion variant [MLL exon 11 (8) with SEPT2 exon 3 - type III fusion transcript] in a case of therapy-related myelodysplastic syndrome (t-MDS) (Table 2; Fig. 2). ${ }^{31,32}$

\section{B. The MLL-SEPT5 Gene Fusion}

The SEPT5 gene was first described as a $M L L$ fusion partner in two infant twins with AML of the M1 and M2 subtypes and a $t(11 ; 22)(\mathrm{q} 23 ; \mathrm{q} 11)$ (Table 2). ${ }^{15}$ Sequencing analysis revealed that both patients had an in-frame fusion of MLL exon 10 (7) with SEPT5 exon 3 (type I fusion transcript) (Fig. 2). Subsequently, a third MLL-SEPT5 fusion was detected in an adult with AMLM2 (Table 2). ${ }^{33}$ In this particular case, a fusion between $M L L$ exon 9 (6) and SEPT5 exon 4 was detected (type II fusion transcript) (Fig. 2).

\section{The MLL-SEPT6 Gene Fusion}

Rearrangements recombining 11q23 and Xq24 and resulting in MLL-SEPT6 fusions are usually complex, sometimes cryptic, as a result of the opposite orientation of MLL and SEPT6 on the respective chromosome arms, with 
Septins in Myeloid Neoplasia

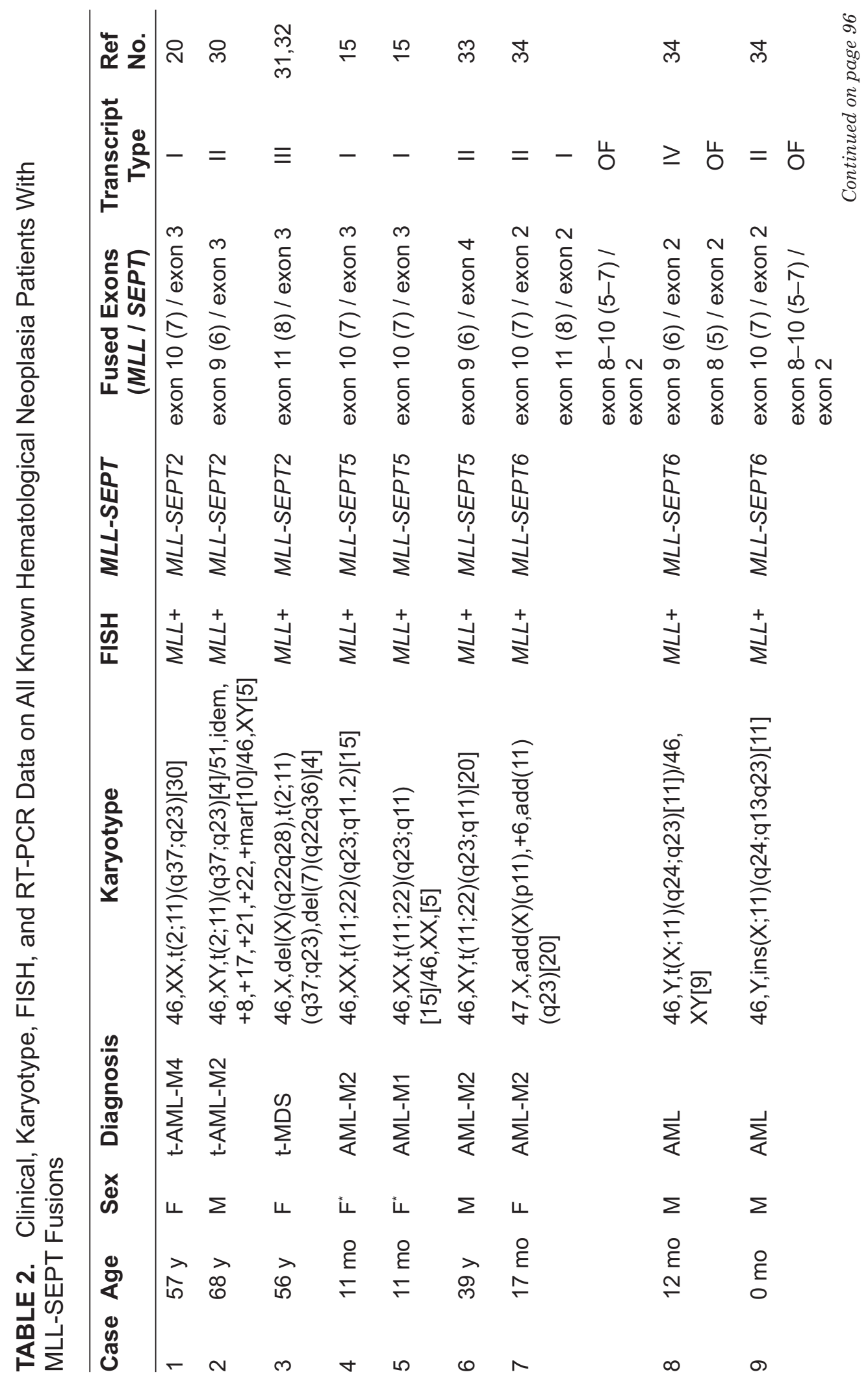


N. Cerveira, J. Santos, \& M.R. Teixeira

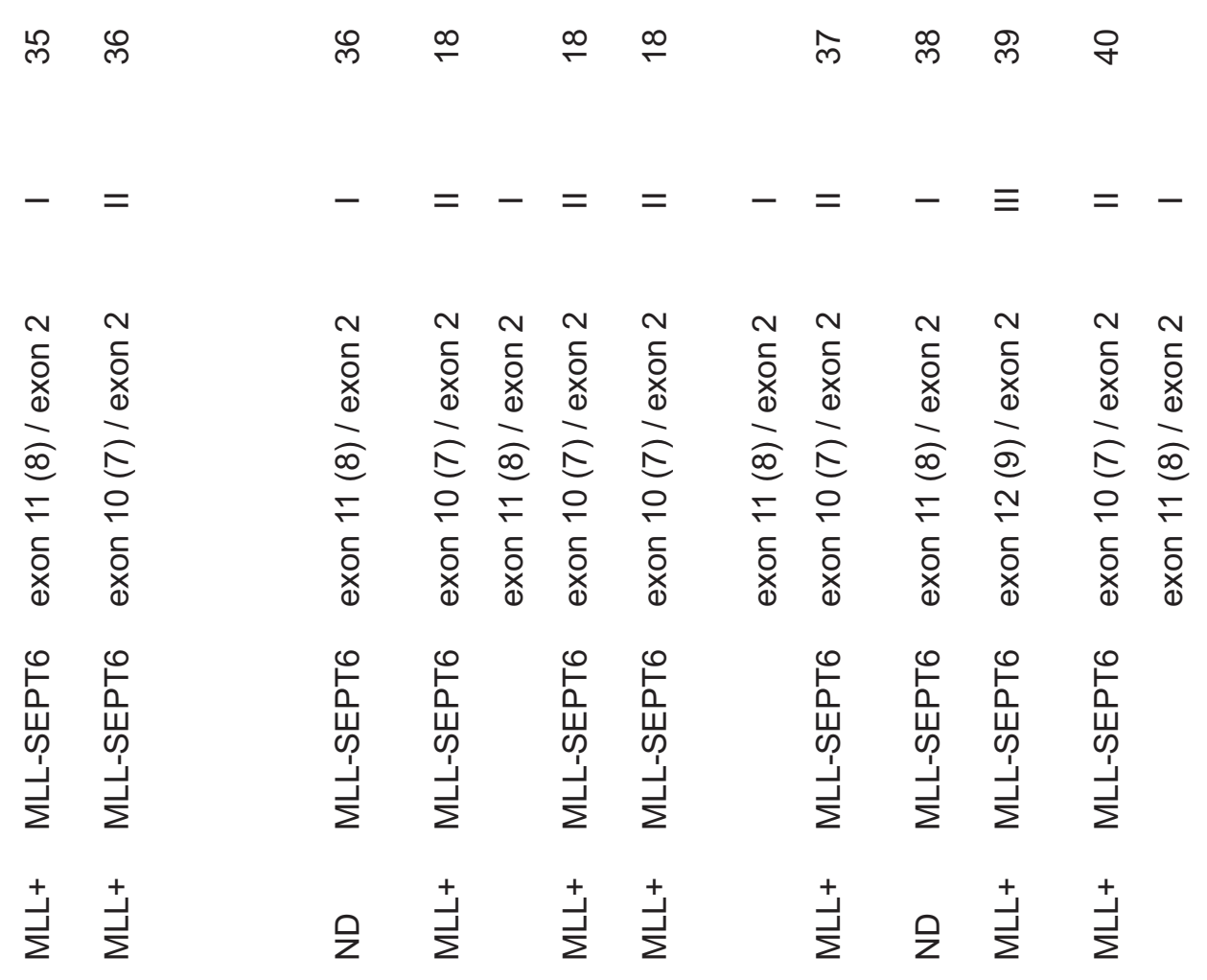

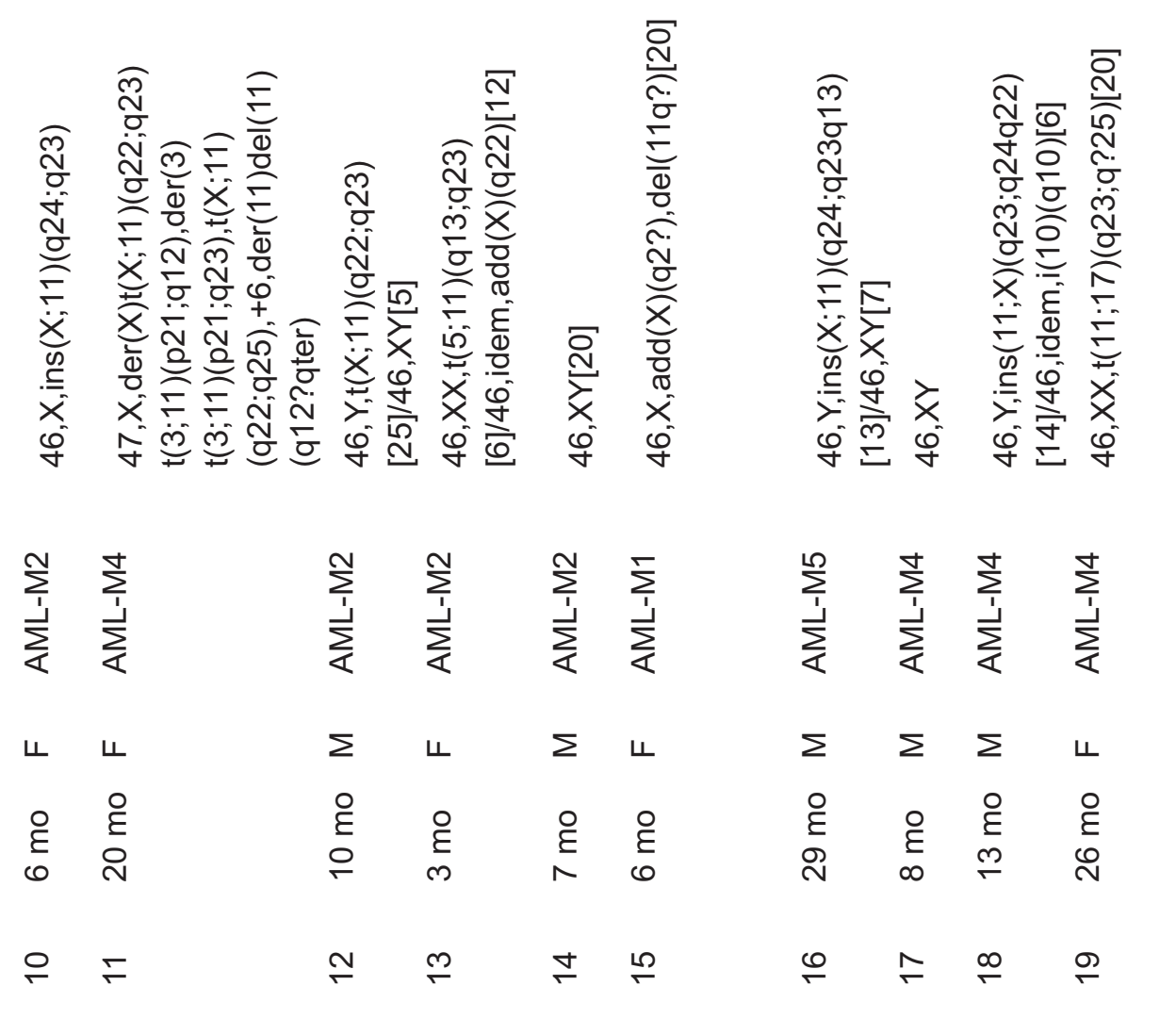


Septins in Myeloid Neoplasia

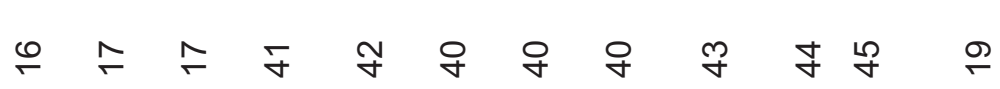

$$
\begin{aligned}
& ---\frac{Q}{2}=-\equiv==-
\end{aligned}
$$

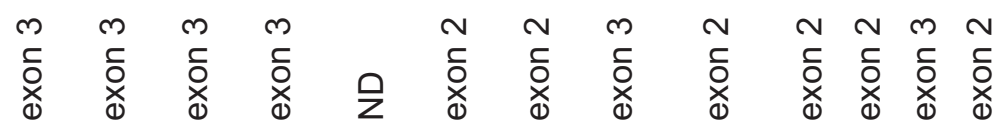

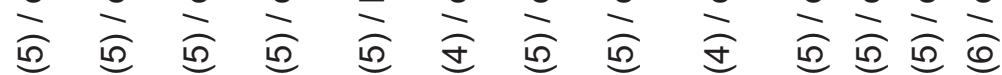

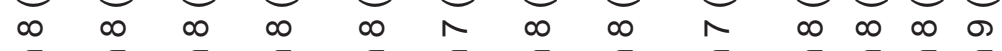

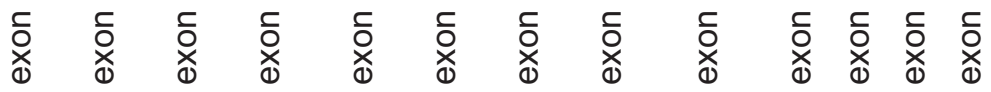

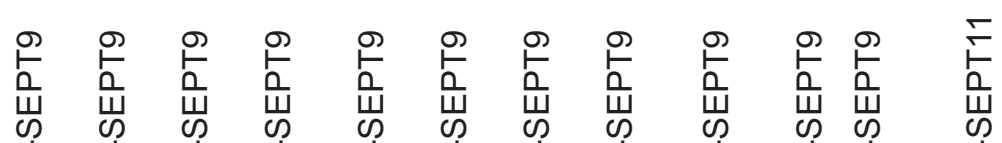

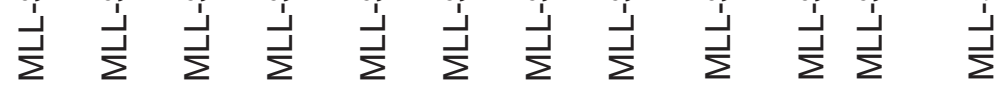

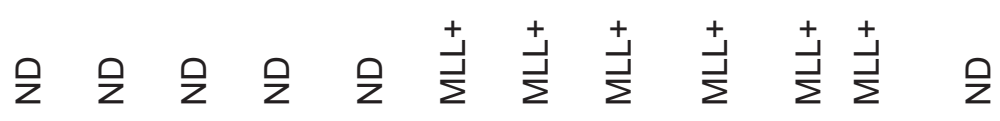

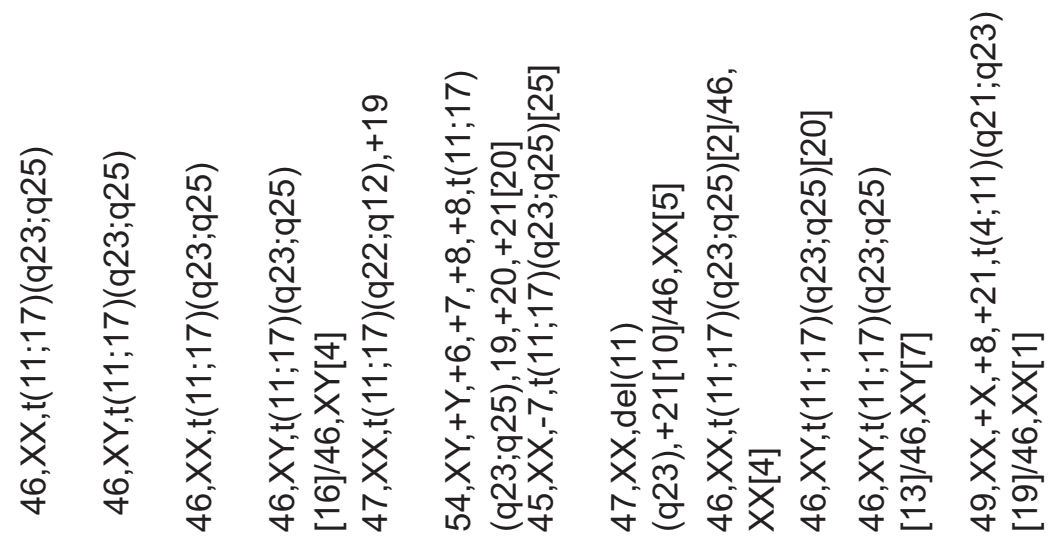

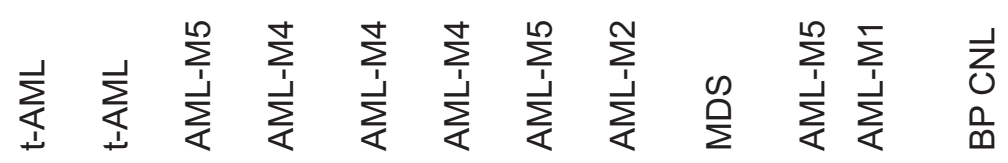

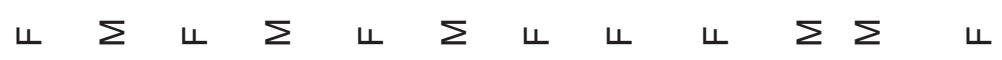

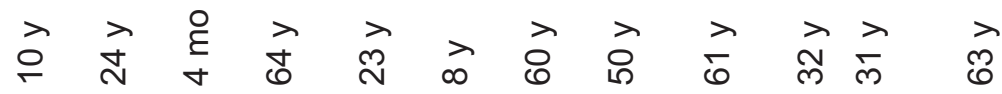

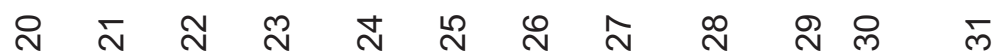

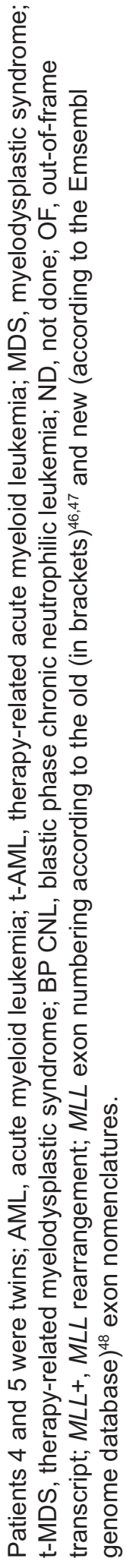




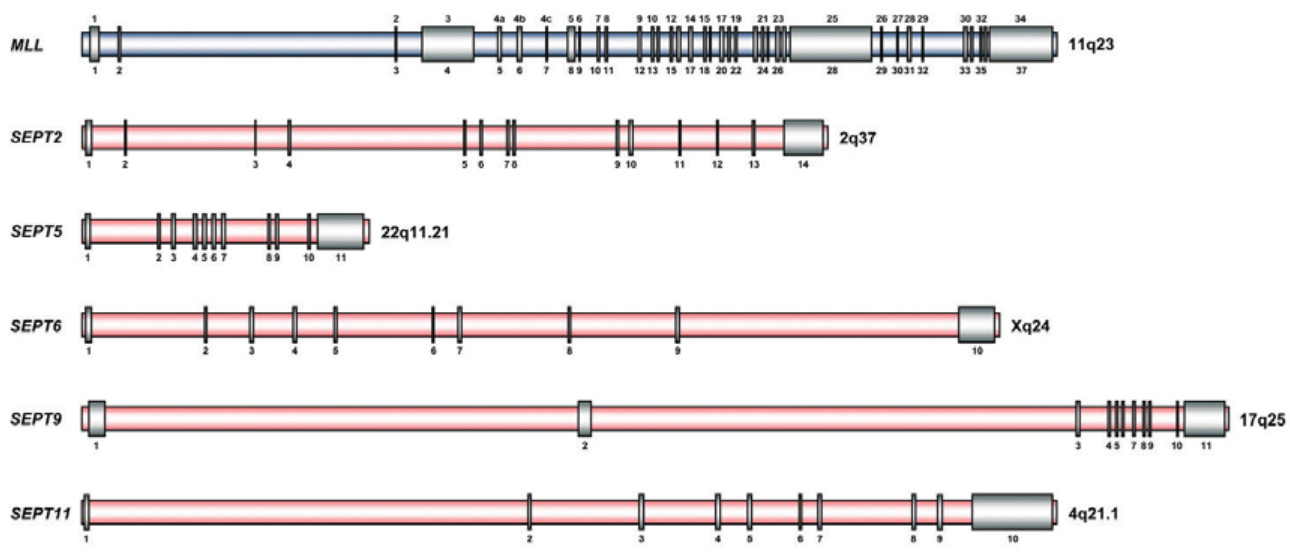

FIGURE 1. Schematic representation of $M L L$ and all septin genes involved in fusions with MLL (SEPT2, SEPT5, SEPT6, SEPT9, and SEPT11). The MLL gene structure is depicted with the old (above) and new (below, according to the Ensembl genome database) exon nomenclatures. ${ }^{46-48}$ Exons are shown in gray and introns in blue (MLL) or pink (SEPT). Gene names are provided on the left side, and the chromosome band location is on the right side.

several different types of chromosomal rearrangements described that can generate the MLL-SEPT6 in-frame fusion (Table 2). ${ }^{18,34-40}$ Thus far, four different types of in-frame $M L L-S E P T 6$ fusion variants have been identified in 13 patients with AML (Table 2). These fusion transcripts, named type I to IV, correspond to fusions between $M L L$ exons 9 (6), 10 (7), 11 (8), and 12 (9) and SEPT6 exon 2 (Table 2; Fig. 2). ${ }^{18,34-40}$ As in all other MLL-SEPT fusions reported, the MLL-SEPT6 fusion is expected to give rise to chimeric fusion proteins, in which almost the entire open reading frame of SEPT6, containing all three septin function-defining domains, is fused with the $\mathrm{N}$-terminal moiety of $M L L .^{18,34-40}$ The presence of out-of-frame alternative splicing variants can also be detected in patients with $M L L-S E P T 6$ fusion, but its biologic relevance is unclear. ${ }^{34}$

\section{The MLL-SEPT9 Gene Fusion}

The MLL-SEPT9 fusion, resulting from a translocation between 11q23 and 17q25, has been described in 11 cases to date (Table 2). ${ }^{16,17,41-45}$ As opposed to other cases with $M L L-S E P T$ fusions, patients with $M L L-S E P T 9$ gene fusions are heterogeneous regarding both age (age range, 4 months to 64 years) and clinical presentation: one MDS case, two t-AML cases, and eight cases of de novo AML (Table 2). Three distinct fusion variants have been described (types I to III) involving fusion of MLL exons 7 (4) or 8 (5) with SEPT9 exons 2 or 3 (Table 2; Fig. 2). Owing to the fact that the consensus MLL-SEPT9 


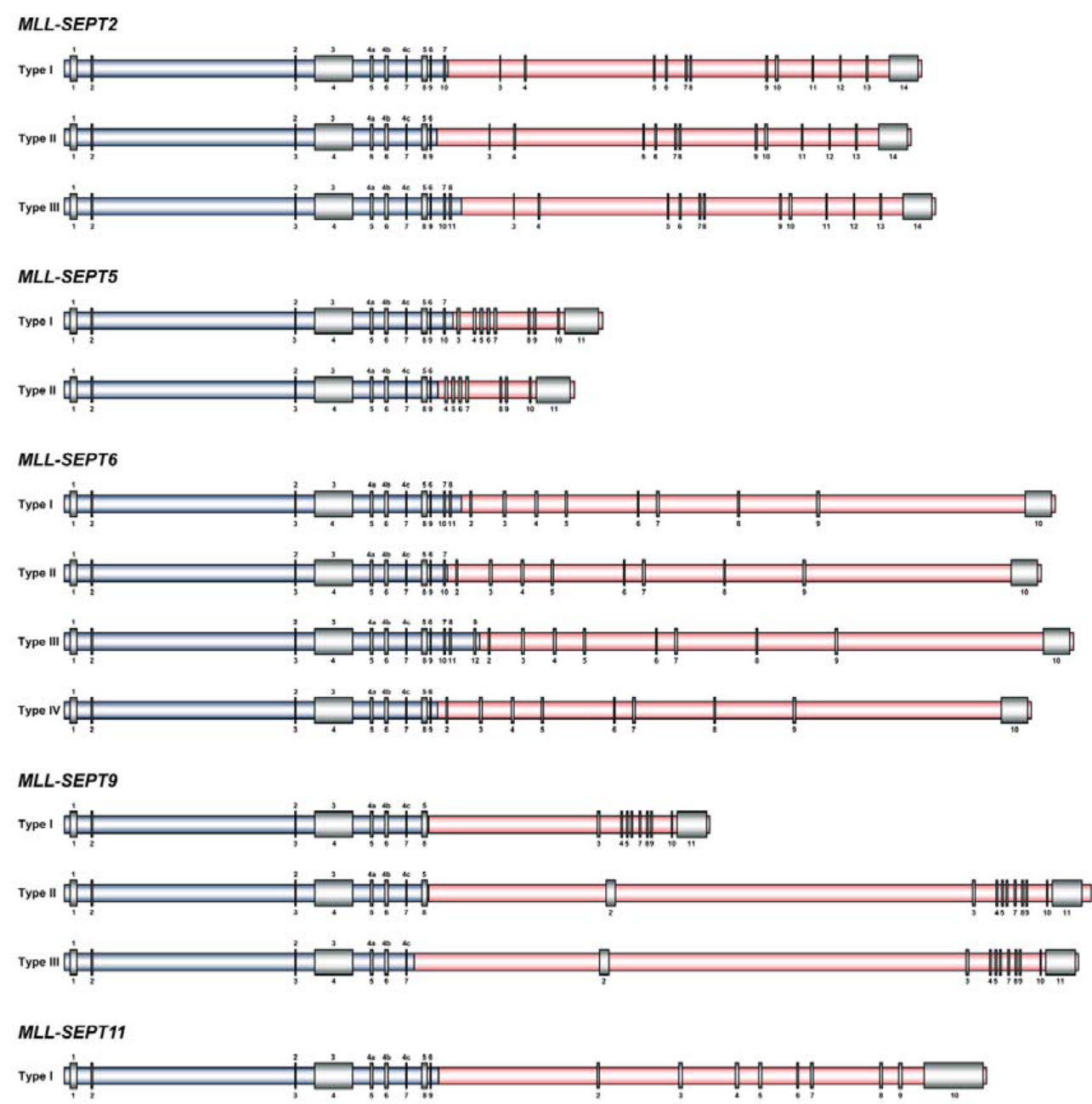

FIGURE 2. Schematic representation of the gene structure of all known MLL-SEPT fusion variants. The $M L L$ gene structure is depicted with the old (above) and new (below, according to the Ensembl genome database) exon nomenclatures. ${ }^{46-48}$ Exons are shown in gray and introns in blue (MLL) or pink (SEPT).

chimeric transcript always fuses $M L L$ sequences between exons 7 (4) to 9 (6) with SEPT9 exons 2 and 3, the chimeric protein is only partially affected by the wild-type SEPT9 $5^{\prime}$ splice variants. ${ }^{41-45}$

\section{E. The MLL-SEPT11 Gene Fusion}

The $\mathrm{t}(4 ; 11)(\mathrm{q} 21 ; \mathrm{q} 23)$ is a recurring chromosomal translocation observed in acute leukemia that usually fuses the $M L L$ gene on 11q23 with the $A F F 1$ gene on chromosome $4 \mathrm{q} 21 . .^{53-56} A F F 1$ is the most frequent translocation partner gene of $M L L$ in acute leukemia (approximately $42 \%$ of all $M L L$-rearranged 


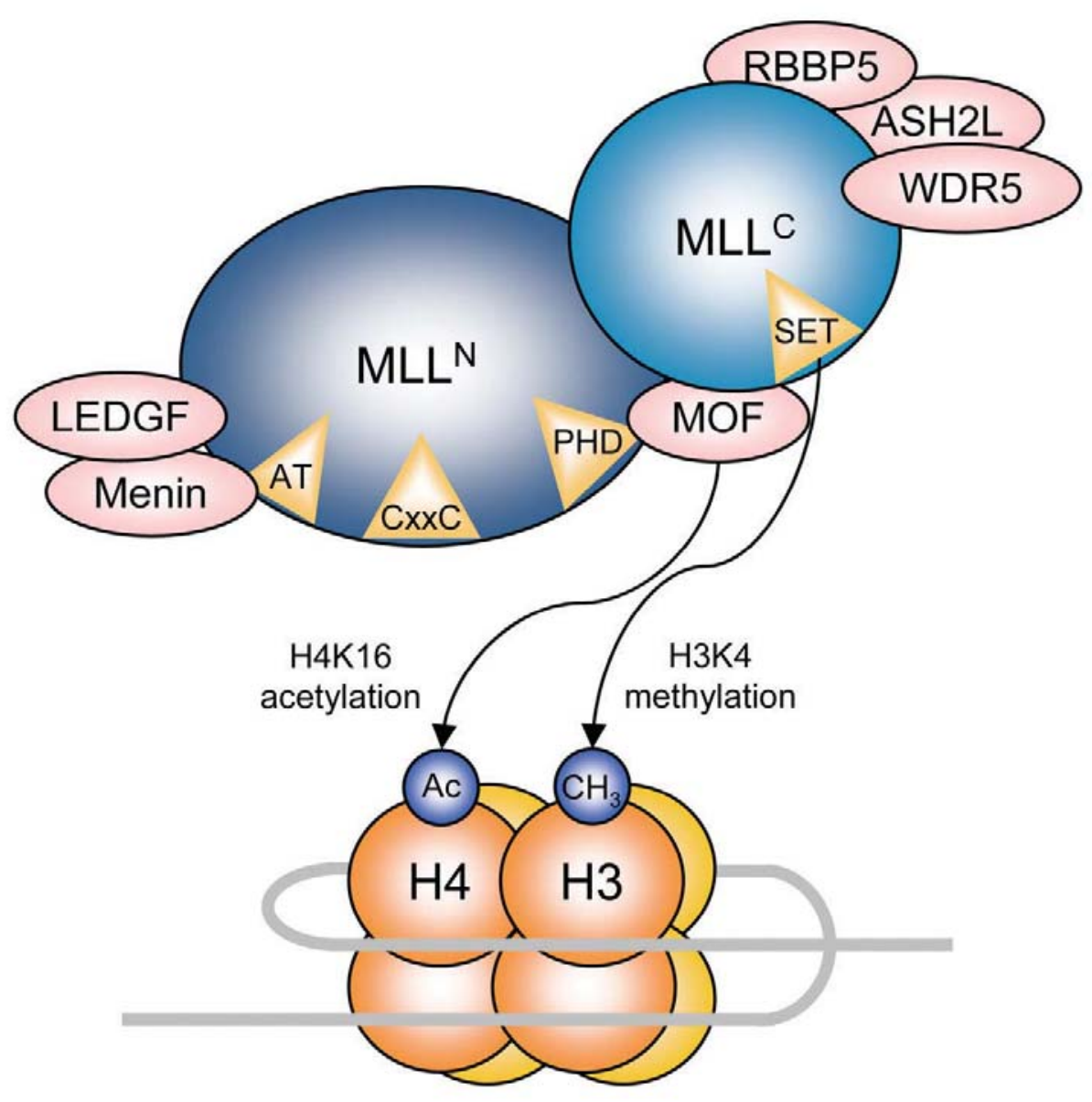

FIGURE 3. The MLL protein complex. After post-transcriptional proteolytic cleavage by taspase 1 the amino terminal $\left(\mathrm{MLL}^{\mathrm{N}}\right)$ and the carboxyl terminal $\left(\mathrm{MLL}^{\mathrm{C}}\right)$, MLL subunits are incorporated into a macromolecular complex with histone methyltransferase and acetyltransferase activity that regulate expression of several target genes. The SET domain is responsible for the specific methylation of histone $\mathrm{H} 3$ at lysine 4 . MOF is the histone $\mathrm{H} 4$ lysine 16-specific acetyltransferase. Menin and LEDGF are MLLassociated proteins that provide a platform for the protein complex to bind to chromatin. RBBP5 and ASH2L are necessary for the MLL methyltransferase activity. The WDR5 protein recognizes the histone H3 lysine 4 methyl-mark introduced by MLL. AT, AT-hooks DNA-binding domain; CxxC, zinc-finger motif; PHD, plant homeodomain; $\mathrm{H} 3$, histone $\mathrm{H} 3$; $\mathrm{H} 4$, histone $\mathrm{H} 4$.

cases) and is characteristic of ALL, in which it can be found in nearly $34 \%$ and $90 \%$ of pediatric and adult cases with $M L L$ rearrangements, respectively. ${ }^{43,45,53}$ Interestingly, SEPT11, which shares the chromosomal localization with $A F F 1$, was identified recently as a fusion partner of $M L L$ in the leukemia cell line CNLBC1 derived from a 63-year old female patient with chronic neutrophilic leukemia $(\mathrm{CNL})$ in transformation and a $\mathrm{t}(4 ; 11)(\mathrm{q} 21 ; \mathrm{q} 23)$ (Table 
2). ${ }^{19}$ This observation suggests that detailed molecular analysis is essential for the identification of fusion partners in patients with $M L L$ rearrangements. In this particular case, MLL exon 9 (6) was fused with SEPT11 exon 2 (Fig. 2), leading to the retention of all three septin defining domains in the MLLSEPT11 protein, as it seems to occur with all cases of MLL-SEPT fusions.

\section{F. Mechanism of Origin of MLL-SEPT Fusions}

Leukemias presenting translocations involving the $M L L$ gene on chromosome $11 \mathrm{q} 23$ show unique clinical and biological characteristics. $M L L$ translocations are likely the result of a failure of appropriate DNA double-strand-break repair in developing hematopoietic cells. ${ }^{57}$ Genomic breakpoints in $M L L$ cluster between exons 8 (5) and 13 (10) in the $8.3 \mathrm{~Kb}$ breakpoint cluster region (BCR), resulting in the deletion of the PHD and distal domains and fusion to one of many different translocation partners. ${ }^{55}$ Presumably, the breaks are limited to this region because more proximal or distal breaks are not compatible with transformation. ${ }^{58}$

Several DNA motifs implicated in recombination of DNA have been identified and localized within the $M L L \mathrm{BCR}$. These include topoisomerase II binding sites and Alu sequences. ${ }^{59-61}$ Also, a high-affinity scaffold attachment region (SAR) has been identified within the telomeric ( $\left.3^{\prime}\right)$ region of the $M L L$ BCR ${ }^{60,61}$ SARs are sites for binding of DNA to nuclear matrix proteins, functioning to maintain the structure of chromosomal loops and to allow regulation of transcription, DNA replication, and recombination..$^{59,60}$ Interestingly, MLL rearrangements are found in more than $70 \%$ of infant leukemias but are less frequent in leukemias from older children. ${ }^{53,55} M L L$ translocations are also found in nearly $10 \%$ of AMLs in adults and in therapy-related leukemias that develop in patients who had been previously treated with topoisomerase II inhibitors for other malignancies. ${ }^{55}$ Strikingly, all three cases with the $M L L$ SEPT2 gene fusion were adult patients (age range, 54-68 years old) with t-MDS/t-AML after chemotherapy for a previous neoplasia with topoisomerase II inhibitors. ${ }^{20,33-37}$ As already stated, topoisomerase II inhibitor-related AML can be distinguished from other therapy-related leukemia by its genetic signature: balanced translocations involving the $M L L$ gene. ${ }^{62}$ The identification of two sequences with $94.4 \%$ homology with the topoisomerase II consensus cleavage site in one of the patients with $M L L-S E P T 2$ fusion located in $M L L$ intron 7 and in SEPT2 intron 2, provides support to a link between topoisomerase II inhibitor therapy and the origin of the MLL-SEPT2 fusion gene. ${ }^{20}$ The same topoisomerase II signature was also detected in the intronic regions involved in the rearrangements of patients with $M L L-S E P T 6$ fusion. ${ }^{34}$ Indeed, in these patients, the detection of a topoisomerase II recognition sequence in SEPT6 intron 1 also supports the hypothesis that exposure to topoisomerase II 
N. Cerveira, J. Santos, \& M.R. Teixeira

inhibitors can result in double-strand DNA breaks that trigger the error-prone nonhomologous end-joining pathway, which in turn can lead to formation of the MLL-SEPT6 fusion oncogene..$^{34}$ Despite the different age distribution (the MLL-SEPT2 cases are adults and the MLL-SEPT6 cases are children), it is tempting to speculate that the cause of the MLL-SEPT gene fusions in both groups might be the exposure to topoisomerase II inhibitors. In agreement with this hypothesis are some studies that suggest a causal relationship between infant leukemia induced in utero and maternal exposure to dietary compounds that can act as topoisomerase II poisons, ${ }^{63-66}$ and the observation that all MLL-SEPT2 cases are the result of treatment with chemotherapy containing topoisomerase II inhibitors..$^{20,30-32}$ Nevertheless, one must be cautious in interpreting these findings because topoisomerase II consensus cleavages sites are either short, highly redundant, or both, and thus their chance occurrence at breakpoint junctions is likely to be frequent. Therefore, their presence at a given translocation breakpoint should not be automatically taken to imply that they are directly involved in the mechanisms of rearrangement. ${ }^{67}$ Additional studies with higher numbers of $M L L-S E P T 2$ and $M L L-S E P T 6$ cases are warranted to confirm or refute this relationship. In addition, whenever possible, analysis of genomic sequences in the vicinity of other MLL-SEPT fusions should be performed. Indeed, and to our knowledge, only one study has thoroughly characterized the genomic sequence in the vicinity of a $M L L$ SEPT5 fusion, but the presence of topoisomerase II recognition sequences in the SEPT5 genomic region involved in the rearrangement was not reported. ${ }^{15}$

\section{G. Clinico-Pathological Association of MLL-SEPT Fusions}

The observation that five of 14 septin genes are involved in rearrangements with $M L L$ makes the septins the protein family with most members involved in rearrangements with the $M L L$ gene, and suggests that the involvement of this protein family in $M L L$-related leukemia is not a chance event. This hypothesis is also supported by additional observations. First, although chromosomal translocations disrupting the $M L L$ gene in general are associated with both AML and ALL (corresponding to $27 \%$ and $73 \%$ of all $M L L$ rearranged cases, ${ }^{53}$ respectively), patients with $M L L-S E P T$ fusions show a clear bias toward AML (27 of 30 cases [90\%], with the remaining patients being one MDS, one t-MDS, and one CNL in blastic phase) (Table 2). ${ }^{15-20,30-45}$ Second, all of the reported $M L L$-septin fusions are in frame and the breakpoints are found at the very $5^{\prime}$ end of known septin open reading frames (Table 2; Fig. 2). ${ }^{15-20,30-45}$ This finding is in contrast with other $M L L$ fusion partners, in which breaks can occur in its telomeric or centromeric region and, in some genes, at both its $3^{\prime}$ and $5^{\prime}$ extremities. ${ }^{53}$ 
Patients with $M L L$-associated AML generally show features of monocytic differentiation and are usually classified as FAB M4 or M5 subtypes. ${ }^{68}$ This trend is observed in the MLL-SEPT9 subgroup (10 of 11 cases), but it is not apparent in the other $M L L-S E P T$ subgroups, in which a predominance of M1 and M2 cases (10 of 16) is observed (Table 2). When considered as a whole, the incidence of monocytic features in MLL-SEPT cases is 54\% (13 out of 24 FAB-typed cases). Another interesting finding is the association of a particular $M L L-S E P T$ fusion with specific patient characteristics. For instance, all of the 13 reported patients with a $M L L-S E P T 6$ rearrangement are children, with an age range between 0 and 29 months. ${ }^{18,35-40}$ Because the majority $(65 \%)$ of pediatric patients with $M L L$ rearrangements have ALL, ${ }^{68}$ we can hypothesize that the SEPT6 domains of the MLL-SEPT6 chimeric protein may contribute to myeloblastic leukemogenesis in children. On the other hand, the patients with MLL-SEPT2 fusion in all three of the published results are adults (age range, 56-68 years) with therapy-related myeloid neoplasia. ${ }^{20,30-32}$

For AML it appears that the prognostic effect of an $M L L$ rearrangement may depend on the particular translocation partner involved. For instance, several studies of children and adults with AML with MLL-MLLT3 fusion have shown superior event-free and overall survival compared with patients with other $M L L$ rearrangements. ${ }^{69,70}$ In contrast, AML patients with a $M L L$ MLLT10 fusion have been shown to have a poor outcome in some studies, ${ }^{71}$ but superior long-term survival in others. ${ }^{72}$ As for $M L L$ fusions with septin gene family members, their prognostic significance remains unknown because of the small number of cases reported in each subgroup and the unavailability of follow-up data in most cases. ${ }^{15-20,30-45}$

\section{H. Mouse Models of MLL-SEPT Fusions}

In vitro and in vivo models of the MLL-SEPT6 fusion have provided some insight into MLL-SEPT leukemogenesis. ${ }^{73,74}$ Fusion partner-mediated homooligomerization of MLL-SEPT6 was shown to be essential to immortalize hematopoietic progenitors in vitro. ${ }^{73}$ In addition, MLL-SEPT6 induced myeloproliferative disease with long latency in mice, but not acute leukemia, implying that, at least in this model, secondary genotoxic events are required to develop leukemia. ${ }^{73}$ Indeed, in vitro and in vivo model systems of leukemogenesis of MLL-SEPT6 fusion proteins with concomitant activated FLT3 not only transformed hematopoietic progenitors in vitro, but also induced acute biphenotypic or myeloid leukemia with short latency in vivo. ${ }^{73}$ Furthermore, loss of SEPT6 did not alter the phenotype of myeloproliferative disease induced by MLL-SEPT6, suggesting that SEPT6 does not function as a tumor-suppressor gene. ${ }^{74}$ 
N. Cerveira, J. Santos, \& M.R. Teixeira

These observations need to be confirmed in the case of other MLL-SEPT fusions; to our knowledge, no in vivo and in vitro models have been developed for the remaining $M L L$ fusions with other septin family genes.

\section{SEPTIN EXPRESSION ABNORMALITIES}

Deregulation of the expression of septin family genes has been reported in various human diseases, including hematological neoplasias. In hematological cancers, septin expression abnormalities can be divided into two major groups: septin expression abnormalities associated with $M L L$ gene fusions, which have only been described in AML thus far, and septin expression abnormalities that are not associated with $M L L$ gene fusions, which have characteristically been detected in AML but also observed in ALL patients.

\section{A. Septin Expression Abnormalities Associated With MLL Gene Fusions}

Septin expression changes have been found in hematological neoplasia associated with $M L L$ gene fusion, with concomitant $M L L$ downregulation. Indeed, in a recent study by our group, we found a statistically significant reduction of wild-type SEPT2 and MLL-SEPT2 combined expression in cases with the $M L L-S E P T 2$ gene fusion, which was accompanied by downregulation of wild-type $M L L$ and $M L L-S E P T 2$ combined expression..$^{27}$ The downregulation of both $S E P T 2$ and $M L L$ in $M L L-S E P T 2$ myeloid neoplasias was statistically significant when compared with both normal controls and with other leukemia genetic subgroups (including those with other $M L L$ gene fusions). ${ }^{27}$ It is conceivable that deregulation of SEPT2 expression can occur as a result of its fusion with $M L L$ (by haplo-insufficiency, for example), because the $M L L$ $S E P T 2$ gene is controlled by the MLL promoter. However, the magnitude of $S E P T 2$ underexpression far exceeds the maximum $50 \%$ reduction that would be expected if one of the SEPT2 alleles had its expression shut down. ${ }^{27}$ One explanation for the observed downregulation of $M L L, S E P T 2$, and $M L L$ $S E P T 2$ could be the involvement of a transcriptional mechanism regulated via an epigenetic mark. DNA methylation within the promoter region of a gene can result in chromatin compaction and inhibition or downregulation of gene transcription, and aberrant promoter methylation in cis is often responsible for gene silencing in a variety of malignancies. ${ }^{75}$ However, we found no DNA methylation in the CpG island located 5' of the SEPT2 gene (encompassing the predicted $S E P T 2$ promoter region), suggesting that hypermethylation of wild-type $S E P T 2$ is likely not the mechanism responsible for the observed gene silencing. ${ }^{27}$ 
SEPT2 is not the only septin family gene that has its expression downregulated as a result of fusion with $M L L$. Our group also found a statistically significant reduction of the wild-type SEPT6 and MLL-SEPT6 combined expression in cases with the $M L L-S E P T 6$ gene fusion, which was accompanied by downregulation of wild-type $M L L$ and $M L L-S E P T 6$ combined expression. ${ }^{28}$ A similar trend, although not statistically significant, was also observed for SEPT9, but not MLL, in MLL-SEPT9 cases. ${ }^{28}$ These findings suggest that downregulation of both $M L L$ and SEPT genes is a common event in $M L L$ $S E P T$ myeloid neoplasia. However, downregulation of $M L L$ when fused with a partner gene does not seem to be restricted to $M L L-S E P T$ fusions. Indeed, $M L L$ downregulation has also been observed by others and us in patients with $M L L-M L L T 3$ fusions, ${ }^{28,76}$ suggesting that this can be a common event at least in some groups of $M L L$-related leukemia. Our findings therefore indicate that some MLL fusion proteins present leukemogenic properties even if they are expressed in lower levels compared with normal $M L L$ expression.

\section{B. Septin Expression Abnormalities Not Associated With MLL Gene Fusions}

In a previous study by our group, we studied bone marrow samples collected at diagnosis from patients with myeloid neoplasia who were selected to represent the major AML genetic subgroups, including cases with RUNX1$R U N X 1 T 1, C B F B-M Y H 11$, and PML-RARA rearrangements and cases with normal karyotype. ${ }^{28}$ We observed that downregulation of some septin genes seemed to be a widespread phenomenon in myeloid neoplasia without $M L L$ gene fusions. For instance, we found that $P M L-R A R A$ AML was clearly distinct from other AML groups regarding septin gene expression abnormalities, because it showed downregulation of nine different septin genes (SEPT1, SEPT2, SEPT3, SEPT4, SEPT5, SEPT7, SEPT9, SEPT10, and SEPT13). ${ }^{28}$ The biological meaning of this downregulation is not known, but can be associated with the well-known role of the PML-RARA quimeric protein as a potent transcriptional repressor. In addition, we also observed downregulation of SEPT1, SEPT5, and SEPT10 in CBFB-MYH11 AML, RUNX1-RUNX1T1 AML, and normal karyotype AML. ${ }^{28}$ Moreover, both SEPT4 and SEPT9 were also shown to be under-expressed in all AML subgroups with the exception CBFB-MYH11 AML. ${ }^{28}$

On the other hand, expression changes of SEPT8, SEPT11, and SEPT12 do not seem to be frequent in myeloid neoplasia, because they were not found in any of the groups studied. SEPT14 expression was not detected in any of the AML subgroups studied, which is in agreement with the observation that it is expressed only in testicular tissue. ${ }^{7}$ 
N. Cerveira, J. Santos, \& M.R. Teixeira

As opposed to downregulation, upregulation of septin family genes in hematological neoplasia seems to be a rare event. ${ }^{28}$ Indeed, septin gene overexpression was only detected for the SEPT6 gene and it was restricted to CBFB-MYH11 AML. ${ }^{28}$ The phenotypic impact of septin expression changes in AML remains to be elucidated.

\section{Septin Expression Changes in Other Neoplasias}

The first description of septin expression abnormalities in leukemia other than AML was for the mitochondrial ARTS (SEPT4) protein. ${ }^{26}$ The ARTS transcript, a splice variant of the SEPT4 gene, is lost in the majority (70\%) of childhood ALL, which leads to the suggestion that it can act as a tumorsuppressor gene in ALL. ${ }^{26}$ This observation, associated with the abovedescribed SEPT4 expression abnormalities in several AML genetic subgroups, provides additional support for the association between SEPT4 deregulation and leukemia. Unlike other septin proteins, ARTS is a mitochondrial protein that is released to the cytosol during apoptosis. ${ }^{77}$ The expression of ARTS seems to promote apoptosis in response to several pro-apoptotic stimuli such as Fas, TGF- $\beta$, air-C, etoposide, and STS. ${ }^{26,77-79}$ RNA interference blocking ARTS expression protects cells from TGF- $\beta$-induced apoptosis. ${ }^{78}$ Therefore, our observation that SEPT4 is also downregulated in several AML genetic subgroups could indicate a general mechanism of resistance to apoptosis in leukemogenesis. Indeed, the loss of pro-apoptotic genes is one of the wellknown mechanisms by which transformed cells can obtain selective advantage through reduced susceptibility to apoptotic signals. However, it remains to be elucidated if the observed SEPT4 underexpression in AML is also the consequence of a diminished expression of the ARTS splice variant. SEPT4 expression abnormalities do not seem to be restricted to hematological cancers. Indeed, two SEPT4 alternate splice variants that were identified by screening an expression library were shown to be ectopically expressed in colorectal cancer and melanoma. ${ }^{80}$ Furthermore, ribozyme-mediated downregulation of these transcripts was proven to inhibit growth and tumorigenesis of colorectal cancer in vivo and in vitro. ${ }^{80}$

SEPT9 expression abnormalities are also common in solid tumors. Upregulation of one or more SEPT9 isoforms has been associated with breast, ovarian, and prostate cancer. ${ }^{21-25}$ SEPT9_v1 overexpression has been shown to be associated with accelerated growth kinetics, cell motility, invasion, genomic instability, and morphologic changes in human breast cells ${ }^{25}$ with upregulation of this transcript leading to the stabilization of c-Jun-N-Terminal kinase and contributing to its pro-proliferative activity in mammary epithelial cells. ${ }^{81}$ In addition, recent studies have shown that SEPT9 exon 2 codes for a connection domain to the HIF- $\alpha$ factor, responsible for promoting cell prolif- 
eration and angiogenesis. ${ }^{24,82}$ However, the role of SEPT9 in human neoplasia is far from being elucidated. Indeed, it was shown that SEPT9 expression is downregulated by promoter methylation in head and neck squamous cell carcinoma, ${ }^{29}$ which suggests that SEPT9 may have dual function as both an oncogene and a tumor suppressor gene.

\section{CONCLUSIONS AND FUTURE PERSPECTIVES}

In this review, we have attempted to describe what is known thus far about septin deregulation in myeloid neoplasia. Some septins have been repeatedly identified as in-frame fusion partners of the $M L L$ gene in de novo and therapy-related myeloid neoplasia (mostly AML), both in children and adults. Furthermore, septin expression changes have been described not only in hematological neoplasia, but also in several types of solid tumors. Although current hypotheses regarding the roles of septins in oncogenesis remain speculative for the most part, the fundamental roles of septins in cytokinesis, membrane remodeling, and compartmentalization provide some clues as to how abnormalities in the septin cytoskeleton could be involved in neoplastic disorders. Recent progress in the understanding of septin function has shed some light on how cytoskeletal organization could be linked to cell-cycle progression. ${ }^{83}$ It seems that septins are linked with the control of cell-cycle progression through a DNA damage checkpoint in yeast. ${ }^{83}$ Because one of the more relevant functions of the DNA damage checkpoint in vivo is the prevention of tumor formation in adult tissues, through elimination via apoptosis of abnormal cells, it is plausible that septin abnormalities can result in malfunction of this cell-cycle checkpoint, leading to the accumulation of genetic abnormalities and, eventually, resulting in the formation of an altered clone with oncogenic potential.

A more detailed characterization of the role of septins in normal cellular physiology and in pathological states is clearly needed. The construction of a detailed database of the expression pattern of the several septin isoforms, both in normal and diseased tissues, is essential to understand the modifications of the isoforms and their interactions with other septins and with other proteins. Only by integrating biochemistry data with cell biology and pathology can a detailed knowledge of this family of proteins be obtained. Moreover, and because the existence of known $M L L$ partner genes in chromosomal bands in which septin genes are mapped does not exclude the possibility of $M L L-S E P T$ fusions, detailed molecular analysis in $M L L$ rearranged cases in which the more frequent fusion partners were excluded should be performed to ascertain the full contribution of septins to $M L L$-related leukemogenesis. Finally, because almost the entire open reading frame of the septin partner gene is fused to the $5^{\prime} M L L$ region, it would be interesting to determine the contribution of septin domains, if any, to the leukemogenesis induced by 


\section{N. Cerveira, J. Santos, \& M.R. Teixeira}

MLL-SEPT fusions. Indeed, dimerization of MLL via the septin GTP-binding domain can presumably replace the normal histone methyltransferase function of MLL by that of the SEPT partner protein, resulting in the activation of unrecognized partner genes by yet unknown mechanisms (Fig. 4). Addressing these questions by the development of in vitro and in vivo models of $M L L$ SEPT leukemogenesis should provide clues as to how deregulation of the septin cytoskeleton is involved in neoplastic disorders.

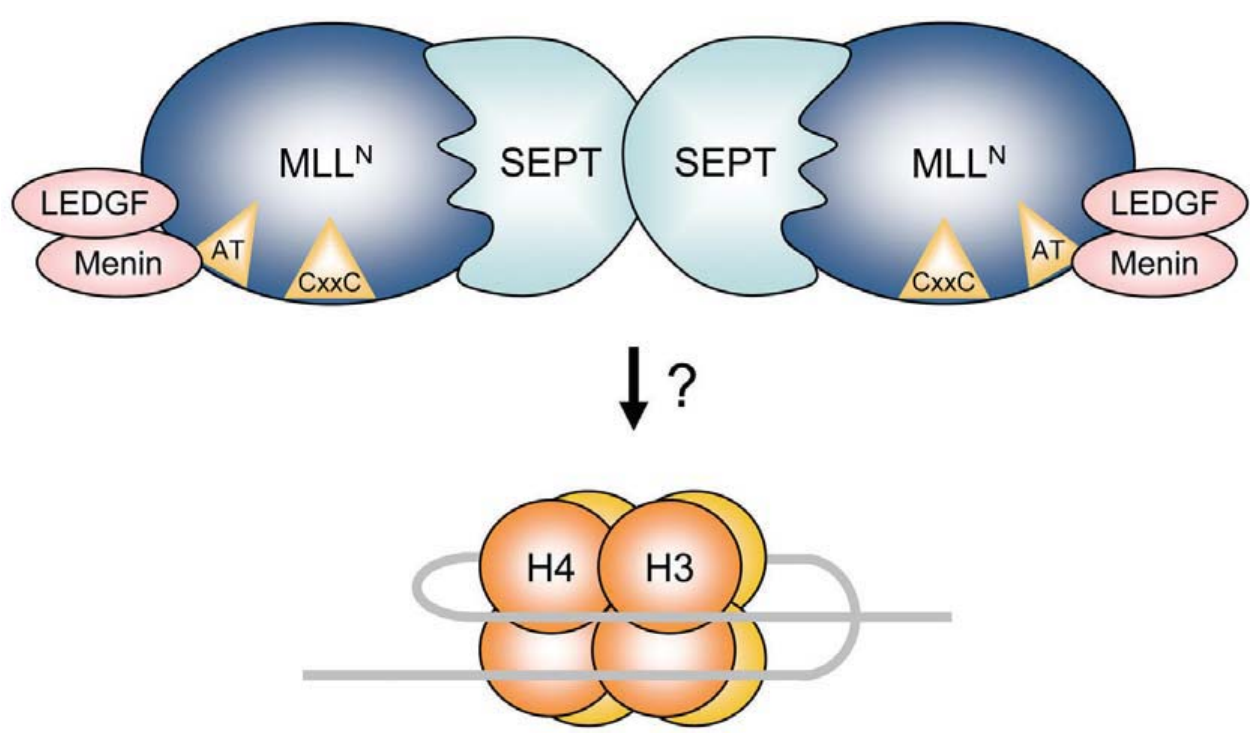

FIGURE 4. Role of MLL-SEPT fusion proteins. MLL-SEPT fusion proteins can likely behave as aberrant transcription factors that replace the normal histone methyltransferase activity of MLL and activate abnormal gene expression programs by unknown mechanisms, as a result of dimerization of MLL via the septin GTP-binding domain. MLLN ${ }^{N}, N$-terminal MLL fragment; AT, AT-hooks DNA-binding domain; CxxC, zinc-finger motif; $\mathrm{H} 3$, histone $\mathrm{H} 3$; $\mathrm{H} 4$, histone $\mathrm{H} 4$.

\section{ACKNOWLEDGMENT}

This research was supported by grants from the Associação Portuguesa Contra a Leucemia (2006-30.2.AP/MJ) and the Comissão de Fomento da Investigação em Cuidados de Saúde (P.I. 26/2007).

\section{REFERENCES}

1. Hall PA, Russell SE. The pathobiology of the septin gene family. J Pathol. 2004;204:489-505.

2. Hartwell LH. Genetic control of the cell division cycle in yeast. IV. Genes controlling bud emergence and cytokinesis. Exp Cell Res. 1971;69:265-76. 


\author{
Septins in Myeloid Neoplasia
}

3. Longtine MS, DeMarini DJ, Valencik ML, Al-Awar OS, Fares H, De Virgilio C, Pringle JR. The septins: roles in cytokinesis and other processes. Curr Opin Cell Biol. 1996;8:106-19.

4. Russell SE, Hall PA. Do septins have a role in cancer? Br J Cancer. 2005;93: 499-503.

5. Leipe DD, Wolf YI, Koonin EV, Aravind L. Classification and evolution of P-loop GTPases and related ATPases. J Mol Biol. 2002;317:41-72.

6. Versele M, Thorner J. Some assembly required: yeast septins provide the instruction manual. Trends Cell Biol. 2005;15:414-24.

7. Peterson EA, Kalikin LM, Steels JD, Estey MP, Trimble WS, Petty EM. Characterization of a SEPT9 interacting protein, SEPT14, a novel testis-specific septin. Mamm Genome. 2007;18:796-807.

8. Weirich CS, Erzberger JP, Barral Y. The septin family of GTPases: architecture and dynamics. Nat Rev Mol Cell Biol. 2008;9:478-89.

9. Spiliotis ET, Nelson WJ. Here come the septins: novel polymers that coordinate intracellular functions and organization. J Cell Sci. 2006;19:4-10.

10. Hall PA, Jung K, Hillan KJ, Russell SE. Expression profiling the human septin gene family. J Pathol. 2005;206:269-78.

11. Sirajuddin M, Farkasovsky M, Hauer F, Kühlmann D, Macara IG, Weyand M, Stark H, Wittinghofer A. Structural insight into filament formation by mammalian septins. Nature. 2007;449:311-5.

12. Sheffield PJ, Oliver CJ, Kremer BE, Sheng S, Shao Z, Macara IG. Borg/septin interactions and the assembly of mammalian septin heterodimers, trimers, and filaments. J Biol Chem. 2003;278:3483-8.

13. Lukoyanova N, Baldwin SA, Trinick J. 3D reconstruction of mammalian septin filaments. J Mol Biol. 2008;376:1-7.

14. Gladfelter AS, Montagna C. Seeking truth on Monte Verita. Workshop on the molecular biology and biochemistry of septins and septin function. EMBO Rep. 2007;8:1120-6.

15. Megonigal MD, Rappaport EF, Jones DH, Williams TM, Lovett BD, Kelly KM, Lerou PH, Moulton T, Budarf ML, Felix CA. t(11;22)(q23;q11.2) in acute myeloid leukemia of infant twins fuses MLL with hCDCrel, a cell division cycle gene in the genomic region of deletion in DiGeorge and velocardiofacial syndromes. Proc Natl Acad Sci USA. 1998;95:6413-8.

16. Osaka M, Rowley JD, Zeleznik-Le NJ. MSF (MLL septin-like fusion), a fusion partner gene of MLL, in a therapy-related acute myeloid leukemia with a $\mathrm{t}(11 ; 17)$ (q23;q25). Proc Natl Acad Sci USA. 1999;96:6428-33.

17. Taki T, Ohnishi H, Shinohara K, Sako M, Bessho F, Yanagisawa M, Hayashi Y. AF17q25, a putative septin family gene, fuses the MLL gene in acute myeloid leukemia with $\mathrm{t}(11 ; 17)(\mathrm{q} 23 ; \mathrm{q} 25)$. Cancer Res. 1999;59:4261-5. 


\author{
N. Cerveira, J. Santos, \& M.R. Teixeira
}

18. Ono R, Taki T, Taketani T, Kawaguchi H, Taniwaki M, Okamura T, Kawa K, Hanada R, Kobayashi M, Hayashi Y. SEPTIN6, a human homologue to mouse Septin6, is fused to MLL in infant acute myeloid leukemia with complex chromosomal abnormalities involving 11q23 and Xq24. Cancer Res. 2002;62:333-7.

19. Kojima K, Sakai I, Hasegawa A, Niiya H, Azuma T, Matsuo Y, Fujii N, Tanimoto M, Fujita S. FLJ10849, a septin family gene, fuses MLL in a novel leukemia cell line CNLBC1 derived from chronic neutrophilic leukemia in transformation with $\mathrm{t}(4 ; 11)(\mathrm{q} 21 ; \mathrm{q} 23)$. Leukemia. 2004;18:998-1005.

20. Cerveira N, Correia C, Bizarro S, Pinto C, Lisboa S, Mariz JM, Marques M, Teixeira MR. SEPT2 is a new fusion partner of MLL in acute myeloid leukemia with $\mathrm{t}(2 ; 11)(\mathrm{q} 37 ; \mathrm{q} 23)$. Oncogene. 2006;25:6147-52.

21. Burrows JF, Chanduloy S, McIlhatton MA, Nagar H, Yeates K, Donaghy P, Price J, Godwin AK, Johnston PG, Russell SE. Altered expression of the septin gene, SEPT9, in ovarian neoplasia. J Pathol. 2003;201:581-8.

22. Scott M, Hyland PL, McGregor G, Hillan KJ, Russell SE, Hall PA. Multimodality expression profiling shows SEPT9 to be overexpressed in a wide range of human tumours. Oncogene. 2005;24:4688-700.

23. Scott M, McCluggage WG, Hillan KJ, Hall PA, Russell SE. Altered patterns of transcription of the septin gene, SEPT9, in ovarian tumorigenesis. Int J Cancer. 2006;118:1325-9.

24. Amir S, Wang R, Matzkin H, Simons JW, Mabjeesh NJ. MSF-A interacts with hypoxia-inducible factor-1alpha and augments hypoxia-inducible factor transcriptional activation to affect tumorigenicity and angiogenesis. Cancer Res. 2006;66:856-8.

25. Gonzalez ME, Peterson EA, Privette LM, Loffreda-Wren JL, Kalikin LM, Petty EM. High SEPT9_v1 expression in human breast cancer cells is associated with oncogenic phenotypes. Cancer Res. 2007;67:8554-64.

26. Elhasid R, Sahar D, Merling A, Zivony Y, Rotem A, Ben-Arush M, Izraeli S, Bercovich D, Larisch S. Mitochondrial pro-apoptotic ARTS protein is lost in the majority of acute lymphoblastic leukemia patients. Oncogene. 2004;23: 5468-75.

27. Cerveira N, Santos J, Bizarro S, Costa V, Ribeiro FR, Lisboa S, Correia C, Torres L, Vieira J, Snijder S, Mariz JM, Norton L, Mellink CHM, Buijs A, Teixeira MR. Both SEPT2 and MLL are down-regulated in MLL-SEPT2 therapy-related myeloid neoplasia. BMC Cancer. 2009;9:147.

28. Santos J, Cerveira N, Bizarro S, Ribeiro FR, Correia C, Torres L, Lisboa S, Vieira J, Mariz JM, Norton L, Snijder S, Mellink CH, Buijs A, Shih L-Y, Strehl S, Micci F, Heim S, Teixeira MR. Expression pattern of the septin gene family in acute myeloid leukemias with and without MLL-SEPT fusion genes. Leuk Res. 2009 Sep 11 [Epub ahead of print].

29. Bennett KL, Karpenko M, Lin MT, Claus R, Arab K, Dyckhoff G, Plinkert P, Herpel E, Smiraglia D, Plass C. Frequently methylated tumor suppressor genes in head and neck squamous cell carcinoma. Cancer Res. 2008;68:4494-9. 


\author{
Septins in Myeloid Neoplasia
}

30. van Binsbergen E, de Weerdt O, Buijs A. A new subtype of MLL-SEPT2 fusion transcript in therapy-related acute myeloid leukemia with $\mathrm{t}(2 ; 11)(\mathrm{q} 37 ; \mathrm{q} 23)$ : a case report and literature review. Cancer Genet Cytogenet. 2007;176: $72-5$.

31. Snijder S, Mellink CHM, van der Lelie H. Translocation (2;11)(q37;q23) in therapy-related myelodysplastic syndrome after treatment for acute promyelocytic leukemia. Cancer Genet Cytogenet. 2008;180:149-52.

32. Cerveira N, Santos J, Pinheiro M, Snijder S, van der Lelie H, Mellink C, Teixeira MR. A novel MLL-SEPT2 fusion variant in therapy-related myelodysplastic syndrome. Cancer Genet Cytogenet. 2008;185:62-4.

33. Tatsumi K, Taki T, Taniwaki M, Nakamura H, Taguchi J, Chen YZ, Bessho F, Yanagisawa M, Hayashi Y. The CDCREL1 gene fused to MLL in de novo acute myeloid leukemia with $\mathrm{t}(11 ; 22)(\mathrm{q} 23 ; \mathrm{q} 11.2)$ and its frequent expression in myeloid leukemia cell lines. Genes Chromosomes Cancer. 2001;30:230-5.

34. Cerveira N, Micci F, Santos J, Pinheiro M, Correia C, Lisboa S, Bizarro S, Norton L, Glomstein A, Åsberg AE, Heim S, Teixeira MR. Molecular characterisation of the MLL-SEPT6 fusion gene in acute myeloid leukaemia: identification of novel fusion transcripts and cloning of genomic breakpoint junctions. Haematologica. 2008;93:1076-80.

35. Borkhardt A, Teigler-Schlegel A, Fuchs U, Keller C, König M, Harbott J, Haas OA. An ins(X;11)(q24;q23) fuses the MLL and the Septin 6/KIAA0128 gene in an infant with AML-M2. Genes Chromosomes Cancer. 2001;32:82-8.

36. Slater DJ, Hilgenfeld E, Rappaport EF, Shah N, Meek RG, Williams WR, Lovett BD, Osheroff N, Autar RS, Ried T, Felix CA. MLL-SEPTIN6 fusion recurs in novel translocation of chromosomes $3, \mathrm{X}$, and 11 in infant acute myelomonocytic leukaemia and in $\mathrm{t}(\mathrm{X} ; 11)$ in infant acute myeloid leukaemia, and MLL genomic breakpoint in complex MLL-SEPTIN6 rearrangement is a DNA topoisomerase II cleavage site. Oncogene. 2002;21:4706-14.

37. Kim HJ, Ki CS, Park Q, Koo HH, Yoo KH, Kim EJ, Kim S-H. MLL/SEPTIN6 chimeric transcript from inv ins(X;11)(q24;q23q13) in acute monocytic leukemia: report of a case and review of the literature. Genes Chromosomes Cancer. 2003;38:8-12.

38. Fu JF, Liang DC, Yang CP, Hsu JJ, Shih LY. Molecular analysis of t(X;11)(q24;q23) in an infant with AML-M4. Genes Chromosomes Cancer. 2003;38:253-9.

39. Kadkol SS, Bruno A, Oh S, Schmidt ML, Lindgren V. MLL-SEPT6 fusion transcript with a novel sequence in an infant with acute myeloid leukemia. Cancer Genet Cytogenet. 2006;168:162-7.

40. Strehl S, König M, Meyer C, Schneider B, Harbott J, Jäger U, von Bergh ARM, Loncarevic IF, Jarosova M, Schmidt HH, Moore SDP, Marschalek R, Haas OA. Molecular dissection of $\mathrm{t}(11 ; 17)$ in acute myeloid leukemia reveals a variety of gene fusions with heterogeneous fusion transcripts and multiple splice variants. Genes Chromosomes Cancer. 2006;45:1041-9. 


\author{
N. Cerveira, J. Santos, \& M.R. Teixeira
}

41. Yamamoto K, Shibata F, Yamaguchi M, Miura O. Fusion of MLL and MSF in adult de novo myelomonocytic leukaemia (M4) with t(11;17)(q23;q25). Int J Hematol. 2002;75:503-7.

42. Shih L-Y, Liang D-C, Fu J-F, Wu J-H , Wang P-N, Lin T-L, Dunn P, Kuo M-C, Tang T-C, Lin T-H, Lai C-L. Characterization of fusion partner genes in 114 patients with de novo acute myeloid leukemia and MLL rearrangement. Leukemia. 2006;20:218-23.

43. Kreuziger LMB, Porcher JC, Ketterling RP, Steensma DP. An MLL-SEPT9 fusion and $\mathrm{t}(11 ; 17)(\mathrm{q} 23 ; \mathrm{q} 25)$ associated with de novo myelodysplastic syndrome. Leuk Res. 2007;31:1145-8.

44. Kurosu T, Tsuji K, Ohki M, Miki T, Yamamoto M, Kakihana K, Koyama T, Taniguchi S, Miura O. A variant-type MLL/SEPT9 fusion transcript in adult de novo acute monocytic leukemia (M5b) with t(11;17)(q23;q25). Int J Hematol. 2008;88:192-6.

45. Santos J, Cerveira N, Correia C, Lisboa S, Torres L, Pinheiro M, Bizarro S, Viterbo L, Mariz JM, Teixeira MR. Coexistence of alternative MLL-SEPT9 fusion transcripts in an acute myeloid leukemia with t(11;17)(q23;q25). Cancer Genet Cytogenet. 2010;197:60-4.

46. Tkachuk DC, Kohler S, Cleary ML. Involvement of a homolog of Drosophila trithorax by 11q23 chromosomal translocations in acute leukemias. Cell. 1992;71:691-700.

47. Parry P, Djabali M, Bower M, Khristich J, Waterman M, Gibbons B, Young BD, Evans G. Structure and expression of the human trithorax-like gene 1 involved in acute leukemias. Proc Natl Acad Sci USA. 1993; 90:4738-2.

48. Nilson I, Löchner K, Siegler G, Greil J, Beck JD, Fey GH, Marschalek R. Exon/ intron structure of the human ALL-1 (MLL) gene involved in translocations to chromosomal region 11q23 and acute leukaemias. Br J Haematol. 1996; 93:966-72.

49. Daser A, Rabbitts TH. The versatile mixed lineage leukaemia gene MLL and its many associations in leukaemogenesis. Semin Cancer Biol. 2005;15:175-88.

50. Li ZY, Liu DP, Liang CC. New insight into the molecular mechanisms of MLLassociated leukemia. Leukemia. 2005;19:183-90.

51. Bennett JM, Catovsky D, Daniel MT, Flandrin G, Galton DA, Gralnick HR, Sultan C. Proposals for the classification of the acute leukaemias. French-AmericanBritish (FAB) co-operative group. Br J Haematol. 1976;33:451-8.

52. Bennett JM, Catovsky D, Daniel MT, Flandrin G, Galton DA, Gralnick HR, Sultan C. Proposed revised criteria for the classification of acute myeloid leukemia. A report of the French-American-British Cooperative Group. Ann Intern Med. 1985;103:620-5.

53. Meyer C, Kowarz E, Hofmann J, Renneville A, Zuna J, Trka J, Ben Abdelali R, Macintyre E, De Braekeleer E, De Braekeleer M, Delabesse E, de Oliveira MP, Cavé H, Clappier E, van Dongen JJ, Balgobind BV, van den Heuvel-Eibrink MM, Beverloo HB, Panzer-Grümayer R, Teigler-Schlegel A, Harbott J, Kjeldsen E, Schnittger S, Koehl U, Gruhn B, Heidenreich O, Chan LC, Yip SF, Krzywinski M, 


\author{
Septins in Myeloid Neoplasia
}

Eckert C, Möricke A, Schrappe M, Alonso CN, Schäfer BW, Krauter J, Lee DA, Zur Stadt U, Te Kronnie G, Sutton R, Izraeli S, Trakhtenbrot L, Lo Nigro L, Tsaur G, Fechina L, Szczepanski T, Strehl S, Ilencikova D, Molkentin M, Burmeister T, Dingermann T, Klingebiel T, Marschalek R. New insights to the MLL recombinome of acute leukemias. Leukemia. 2009;23:1490-9.

54. Domer PH, Fakharzadeh SS, Chen CS, Jockel J, Johansen L, Silverman GA, Kersey JH, Korsmeyer SJ. Acute mixed-lineage leukemia $\mathrm{t}(4 ; 11)(\mathrm{q} 21 ; \mathrm{q} 23)$ generates an MLL-AF4 fusion product. Proc Natl Acad Sci USA. 1993;90: 7884-8.

55. Krivtsov AV, Armstrong SA. MLL translocations, histone modifications and leukaemia stem-cell development. Nat Rev Cancer. 2007;7:823-33.

56. Slany RK. The molecular biology of mixed lineage leukemia. Haematologica. 2009;94:984-93.

57. Richardson C, Jasin M. Frequent chromosomal translocations induced by DNA double-strand breaks. Nature. 2000;405:697-700.

58. Hess JL. MLL: a histone methyltransferase disrupted in leukemia. Trends Mol Med. 2004;10:500-7.

59. Strissel PL, Strick R, Rowley JD, Zeleznik-Le NJ. An in vivo topoisomerase II cleavage site and a DNase I hypersensitive site colocalize near exon 9 in the MLL breakpoint cluster region. Blood. 1998;92:3793-803.

60. Broeker PL, Super HG, Thirman MJ, Pomykala H, Yonebayashi Y, Tanabe S, Zeleznik-Le N, Rowley JD. Distribution of 11q23 breakpoints within the MLL breakpoint cluster region in de novo acute leukemia and in treatment-related acute myeloid leukemia: correlation with scaffold attachment regions and topoisomerase II consensus binding sites. Blood. 1996;87:1912-22.

61. Gu Y, Alder H, Nakamura T, Schichman SA, Prasad R, Canaani O, Saito H, Croce $\mathrm{CM}$, Canaani E. Sequence analysis of the breakpoint cluster region in the ALL-1 gene involved in acute leukemia. Cancer Res. 1994;54:2326-30.

62. Pui CH, Relling MV. Topoisomerase II inhibitor-related acute myeloid leukaemia. Br J Haematol. 2000;109:13-23.

63. Cimino G, Rapanotti MC, Biondi A, Elia L, Lo Coco F, Price C, Rossi V, Rivolta A, Canaani E, Croce CM, Mandelli F, Greaves M. Infant acute leukemias show the same biased distribution of ALL1 gene breaks as topoisomerase II related secondary acute leukemias. Cancer Res. 1997;57:2879-83.

64. Strick R, Strissel PL, Borgers S, Smith SL, Rowley JD. Dietary bioflavonoids induce cleavage in the MLL gene and may contribute to infant leukemia. Proc Natl Acad Sci USA. 2000;97:4790-5.

65. Alexander FE, Patheal SL, Biondi A, Brandalise S, Cabrera ME, Chan LC, Chen Z, Cimino G, Cordoba JC, Gu LJ, Hussein H, Ishii E, Kamel AM, Labra S, Magalhães IQ, Mizutani S, Petridou E, de Oliveira MP, Yuen P, Wiemels JL, Greaves MF. Transplacental chemical exposure and risk of infant leukemia with MLL gene fusion. Cancer Res. 2001;61:2542-6. 


\author{
N. Cerveira, J. Santos, \& M.R. Teixeira
}

66. McDonald TA, Holland NT, Skibola C, Duramad P, Smith MT. Hypothesis: phenol and hydroquinone derived mainly from diet and gastrointestinal flora activity are causal factors in leukemia. Leukemia. 2001;15:10-20.

67. Abeysinghe SS, Chuzhanova N, Krawczak M, Ball EV, Cooper DN. Translocation and gross deletion breakpoints in human inherited disease and cancer I: Nucleotide composition and recombination-associated motifs. Hum Mutat. 2003;22:229-44.

68. Dimartino JF, Cleary ML. MLL rearrangements in haematological malignancies: lessons from clinical and biological studies. Br J Haematol. 1999;106:614-26.

69. Mrózek K, Heinonen K, Lawrence D, Carroll AJ, Koduru PR, Rao KW, Strout MP, Hutchison RE, Moore JO, Mayer RJ, Schiffer CA, Bloomfield CD. Adult patients with de novo acute myeloid leukemia and $\mathrm{t}(9 ; 11)(\mathrm{p} 22 ; \mathrm{q} 23)$ have a superior outcome to patients with other translocations involving band 11q23: a cancer and leukemia group B study. Blood. 1997;90:4532-8.

70. Swansbury GJ, Slater R, Bain BJ, Moorman AV, Secker-Walker LM. Hematological malignancies with $\mathrm{t}(9 ; 11)(\mathrm{p} 21-22 ; \mathrm{q} 23)$--a laboratory and clinical study of 125 cases. European 11q23 Workshop participants. Leukemia. 1998;12:792-800.

71. Dreyling MH, Schrader K, Fonatsch C, Schlegelberger B, Haase D, Schoch C, Ludwig W, Löffler H, Büchner T, Wörmann B, Hiddemann W, Bohlander SK. MLL and CALM are fused to AF10 in morphologically distinct subsets of acute leukemia with translocation $\mathrm{t}(10 ; 11)$ : both rearrangements are associated with a poor prognosis. Blood. 1998;91:4662-7.

72. Lillington DM, Young BD, Berger R, Martineau M, Moorman AV, Secker-Walker LM. The $\mathrm{t}(10 ; 11)(\mathrm{p} 12 ; \mathrm{q} 23)$ translocation in acute leukaemia: a cytogenetic and clinical study of 20 patients. European 11q23 Workshop participants. Leukemia. 1998;12:801-4.

73. Ono R, Nakajima H, Ozaki K, Kumagai H, Kawashima T, Taki T, Kitamura T, Hayashi Y, Nosaka T. Dimerization of MLL fusion proteins and FLT3 activation synergize to induce multiple-lineage leukemogenesis. J Clin Invest. 2005;115:919-29.

74. Ono R, Ihara M, Nakajima H, Ozaki K, Kataoka-Fujiwara Y, Taki T, Nagata K, Inagaki M, Yoshida N, Kitamura T, Hayashi Y, Kinoshita M, Nosaka T. Disruption of Sept6, a fusion partner gene of MLL, does not affect ontogeny, leukemogenesis induced by MLL-SEPT6, or phenotype induced by the loss of Sept 4 . Mol Cell Biol. 2005;25:10965-78.

75. Esteller M. Epigenetics in cancer. N Engl J Med. 2008;358:1148-59.

76. Whitmann SP, Liu S, Vukosavljevic T, Rush LJ, Liu C, Klisovic MI, Maharry K, Guimond M, Strout MP, Becknell B, Dorrance A, Klisovic RB, Plass C, Bloomfield CD, Marcucci G, Caligiuri MA: The MLL partial tandem duplication: evidence for recessive gain-of-function in acute myeloid leukemia identifies a novel patient subgroup for molecular-targeted therapy. Blood. 2005;106:345-52.

77. Larisch S. The ARTS connection: role of ARTS in apoptosis and cancer. Cell Cycle. 2004;3:1021-3. 
78. Gottfried Y, Rotem A, Lotan R, Steller H, Larisch S. The mitochondrial ARTS protein promotes apoptosis through targeting XIAP. EMBO J. 2004;23:1627-35.

79. Larisch S, Yi Y, Lotan R, Kerner H, Eimerl S, Tony Parks W, Gottfried Y, Birkey Reffey S, de Caestecker MP, Danielpour D, Book-Melamed N, Timberg R, Duckett CS, Lechleider RJ, Steller H, Orly J, Kim SJ, Roberts AB. A novel mitochondrial septin-like protein, ARTS, mediates apoptosis dependent on its P-loop motif. Nat Cell Biol. 2000;2:915-21.

80. Tanaka M, Kijima H, Itoh J, Matsuda T, Tanaka T. Impaired expression of a human septin family gene Bradeion inhibits the growth and tumorigenesis of colorectal cancer in vitro and in vivo. Cancer Gene Ther. 2002;9:483-8.

81. Gonzalez ME, Makarova O, Peterson EA, Privette LM, Petty EM. Up-regulation of SEPT9_v1 stabilizes c-Jun-N-terminal kinase and contributes to its pro-proliferative activity in mammary epithelial cells. Cell Signal. 2009;21:477-87.

82. Amir S, Wang R, Simons JW, Mabjeesh NJ. SEPT9_v1 up-regulates hypoxiainducible factor 1 by preventing its RACK1-mediated degradation. J Biol Chem. 2009;284:11142-51.

83. Kremer BE, Adang LA, Macara IG. Septins regulate actin organization and cellcycle arrest through nuclear accumulation of NCK mediated by SOCS7. Cell. 2007;130:777-9. 
GLOBAL DISCUSSION, CONCLUSIONS AND FUTURE PERSPECTIVES 


\section{SUMMARY - RESUMO - RÉSUMÉ}


SUMMARY - RESUMO - RÉSUMÉ 


\section{SUMMARY}

Myeloid neoplasms are a heterogeneous group of clonal disorders of haematopoietic progenitor cells, which lose the ability to differentiate normally and to respond to normal regulators of proliferation. This loss leads to fatal infection, bleeding, or organ infiltration, in the absence of treatment. Among cancer-related chromosomal aberrations that are shedding new light on the origins of myeloid neoplasia, the family of rearrangements involving the $M L L$ gene on chromosome 11 , band q23 is proving to be a fertile area of investigation. The MLL locus is involved in more than 60 different chromosomal translocations with a remarkably diverse group of fusion partners and is associated mostly with acute myeloid leukaemia FAB subtypes M4 or M5. MLL rearrangements include chromosomal translocations, gene internal duplications, chromosome $11 q$ deletions or inversions, and $M L L$ gene insertions into other chromosomes or vice versa.

We established the MLL-SEPT2 gene fusion as the molecular abnormality subjacent to the translocation $\mathrm{t}(2 ; 11)(\mathrm{q} 37 ; \mathrm{q} 23)$ in therapy-related acute myeloid leukaemia, and have also uncovered a novel MLL-SEPT2 alternative fusion variant in therapy-related myelodysplastic syndrome. This study was then extended to encompass MLL-SEPT6 and MLL-SEPT9 myeloid neoplasia patients, with several novel fusion variants uncovered. Interestingly, we found that all cases with the MLL-SEPT2 gene fusion are adults with therapy-related myeloid neoplasia after chemotherapy for a previous neoplasia with topoisomerase II inhibitors. The identification of topoisomerase II consensus cleavage sites in MLL-SEPT2 patients provides support to a link between topoisomerase II inhibitor therapy and the origin of the MLL-SEPT2 fusion gene. The same topoisomerase II signature was also detected in MLL-SEPT6 patients, supporting the hypothesis that exposure to topoisomerase II inhibitors can result in double-strand DNA breaks that trigger the error-prone non-homologous end-joining pathway, which in turn can lead to formation of the MLL-SEPT2 or MLL-SEPT6 fusion oncogenes. Despite the different age distribution (MLL-SEPT2 case are adults and MLL-SEPT6 cases are children), we speculate that the cause of the MLL-SEPT gene fusions in both groups might be exposure to topoisomerase II inhibitors. In agreement with this hypothesis are several studies that suggest a causal relationship between infant leukaemia induced in utero and maternal exposure to dietary compounds that can act as topoisomerase II poisons and the observation that all MLL-SEPT2 cases are the result of treatment with chemotherapy containing topoisomerase II inhibitors. 
In addition, we found that septin expression abnormalities in haematological cancers can be divided in two major groups: septin expression abnormalities associated with $M L L$ gene fusions and septin expression abnormalities not associated with MLL gene fusions. Indeed, we found a statistically significant reduction of wild-type SEPT2 and MLLSEPT2 combined expression in cases with the MLL-SEPT2 gene fusion, which was accompanied by downregulation of wild-type MLL and MLL-SEPT2 combined expression. Concomitant downregulation of both $M L L$ and the SEPT partner gene expression was also observed in MLL-SEPT6 patients. These findings suggest that downregulation of both MLL and SEPT genes is a common event in MLL-SEPT myeloid neoplasia. Downregulation of some septin genes seems also to be a widespread phenomenon in myeloid neoplasia without $M L L$ gene fusions. For instance, we found that PML-RARA leukaemia was clearly distinct from other acute myeloid leukaemia groups regarding septin gene expression abnormalities, since it showed downregulation of nine different septin genes (SEPT1, SEPT2, SEPT3, SEPT4, SEPT5, SEPT7, SEPT9, SEPT10, and SEPT13). In addition, we also observed downregulation of SEPT1, SEPT5, and SEPT10 in CBFB-MYH11 leukaemia, RUNX1-RUNX1T1 leukaemia, and normal karyotype acute myeloid leukaemia. Moreover, both SEPT4 and SEPT9 were also shown to be underexpressed in all acute myeloid leukaemia subgroups with the exception CBFBMYH11 leukaemia. On the other hand, expression changes of SEPT8, SEPT11, and SEPT12 do not seem to be frequent in myeloid neoplasia, since they were not found in any of the groups studied. As opposed to downregulation, upregulation of septin family genes in haematological neoplasia seems to be a rare event. Indeed, septin gene overexpression was only detected for the SEPT6 gene and it was restricted to CBFBMYH11 leukaemia.

Although at this point hypotheses regarding the roles of septins in oncogenesis remain for the most part speculative, their fundamental roles in cytokinesis, membrane remodelling and compartmentalization can provide some clues on how abnormalities in the septin cytoskeleton could be involved in neoplastic disorders. The development of in vitro and in vivo models of MLL-SEPT leukaemogenesis would make possible to address these issues. 


\section{RESUMO}

As neoplasias mielóides constituem um grupo heterogéneo de anomalias clonais das células progenitoras hematopoiéticas, que perderam quer a sua capacidade normal de diferenciação quer a sua capacidade de resposta aos processos de regulação da proliferação celular. Estas anomalias manifestam-se clinicamente pela ocorrência de infecções, hemorragias e infiltração de órgãos pelas células neoplásicas conduzindo, na ausência de tratamento, à morte do indivíduo. A identificação e análise funcional de genes cuja estrutura e/ou expressão é alterada como consequência de rearranjos cromossómicos tem permitido a elucidação dos mecanismos de transformação neoplásica em neoplasias mielóides. Em particular, o estudo das alterações cromossómicas/moleculares envolvendo o gene $M L L$, localizado no cromossoma 11 , banda q23, tem contribuído significativamente para uma melhor compreensão dos mecanismos na origem destas patologias. A família de rearranjos do gene $M L L$ é extensa e inclui delecções, duplicações, inversões e translocações recíprocas envolvendo a banda 11q23 e, apesar da utilização de terapias agressivas, o prognóstico destes doentes é muito reservado. As alterações citogenéticas mais frequentes são as translocações cromossómicas, que resultam na formação de genes de fusão em que a região 5' do gene MLL é fundida com a região 3' de um outro gene denominado parceiro de fusão. Estes genes de fusão são oncogenes que codificam proteínas quiméricas, contendo a extremidade amino do gene $M L L$ fundida com a extremidade carboxilo do parceiro de fusão. A formação duma proteína de fusão é responsável pela desregulação da actividade normal do gene $M L L$ na regulação da transcrição, estando directamente implicada no processo de leucemogénese.

Nesta tese demonstramos que o gene de fusão MLL-SEPT2 é a anomalia molecular subjacente à translocação $\mathrm{t}(2 ; 11)(q 37, q 23)$, na leucemia mielóide aguda resultante de terapia. Uma variante distinta desta anomalia foi igualmente a identificada pela primeira vez na síndrome mielodisplásica resultante de terapia. Este estudo foi posteriormente alargado, de forma a incluir doentes com neoplasia mielóide e fusão do gene MLL com outros genes da família das septinas nomeadamente, SEPT6 e SEPT9, tendo também nestes casos sido identificadas novas variantes de fusão. Curiosamente, verificamos que todos os casos com o gene de fusão MLL-SEPT2 são adultos com neoplasia mielóide resultante do tratamento de uma neoplasia prévia com quimioterapia envolvendo inibidores da enzima topoisomerase II. A identificação de locais de ligação e corte da enzima topoisomerase II em doentes com o gene de fusão MLL-SEPT2, suporta a existência de uma ligação entre o tratamento com inibidores da enzima topoisomerase 
II e a origem do gene de fusão MLL-SEPT2. Esta assinatura da enzima topoisomerase II foi igualmente detectada em doentes MLL-SEPT6, o que parece apoiar a hipótese de que a exposição a inibidores da enzima topoisomerase II pode resultar em quebras da dupla cadeia de $A D N$, activando a via de reparação por junção das extremidades não homólogas ("NHEJ - non-homologous end-joining"). Como esta via é propensa à ocorrência de erros no decurso do processo de reparação da lesão a nível do ADN, o resultado pode ser a formação dos oncogenes de fusão MLL-SEPT2 ou MLL-SEPT6. Apesar da distinta distribuição etária (os casos MLL-SEPT2 são adultos enquanto que os casos MLL-SEPT6 são crianças), podemos especular que a origem dos genes de fusão MLL-SEPT em ambos os grupos pode ser a mesma, ou seja, a exposição a agentes inibidores da enzima topoisomerase II. Duas observações distintas parecem suportar esta hipótese: a existência de vários estudos que sugerem uma relação causal entre a leucemia infantil induzida em útero e uma alimentação materna contendo compostos ricos em inibidores da enzima topoisomerase II, e a observação de que todos os doentes MLL-SEPT2 são o resultado do tratamento prévio com quimioterapia contendo inibidores da enzima topoisomerase II.

Com este trabalho, demonstramos ainda que as anomalias de expressão dos genes da família das septinas em neoplasias hematológicas, podem ser divididas em dois grupos distintos: anomalias de expressão associadas à fusão do gene $M L L$ e anomalias de expressão não associadas à fusão do gene $M L L$. De facto, encontramos uma redução estatisticamente significativa da expressão combinada do gene SEPT2 do tipo selvagem e do gene SEPT2 em fusão, em casos com a fusão MLL-SEPT2, acompanhada pela subexpressão simultânea do gene $M L L$ do tipo selvagem e do gene de fusão $M L L$ em fusão. A subexpressão concomitante do gene $M L L$ e do gene parceiro de fusão SEPT foi igualmente observada em doentes MLL-SEPT6. Estes resultados sugerem que a subexpressão de ambos os genes MLL e SEPT é um evento comum em neoplasias mielóides MLL-SEPT. De igual forma, a subexpressão de alguns genes da família das septinas parece ser um fenómeno generalizado na neoplasia mielóide sem fusão do gene $M L L$. De facto, demonstramos que a leucemia com o gene de fusão PML-RARA é claramente distinta de outros grupos de leucemia mielóide aguda relativamente às anomalias de expressão de genes da família das septinas, uma vez que apresenta subexpressão de nove dos catorze genes desta família identificados até à data (SEPT1, SEPT2, SEPT3, SEPT4, SEPT5, SEPT7, SEPT9, SEPT10 e SEPT13). Além disso, observamos igualmente subexpressão das septinas SEPT1, SEPT5 e SEPT10 nos subgrupos de leucemia com gene de fusão CBFB-MYH11 e RUNX1-RUNX1T1, bem como em doentes com leucemia mielóide aguda e cariótipo normal. Adicionalmente, verificamos que os genes SEPT4 e SEPT9 se encontram subexpressos em todos os 
subgrupos de leucemia mielóide aguda, com a excepção do subgrupo CBFB-MYH11. Por outro lado, alterações da expressão dos genes SEPT8, SEPT11 e SEPT12 não parecem ser frequentes na neoplasia mielóide, não tendo sido identificadas em nenhum dos grupos estudados. Em oposição à subexpressão, a sobreexpressão dos genes da família das septinas em neoplasias hematológicas parece ser um evento raro, tendo apenas tido sido detectada para o caso do gene SEPT6, e restrita à leucemia CBFB-MYH11.

Embora neste momento as hipóteses sobre o papel desempenhado pelas alterações dos genes da família das septinas na oncogénese sejam em grande parte especulativas, o seu papel fundamental a nível da citocinese e da remodelação e compartimentalização das membranas celulares, pode fornecer algumas pistas acerca de como anomalias a nível do citoesqueleto de septinas poderão estar associadas a doenças neoplásicas. O esclarecimento destas questões será possível através do desenvolvimento de modelos in vitro e in vivo que nos permitam um estudo mais aprofundado da leucemogénese MLL-SEPT. 
SUMMARY - RESUMO - RÉSUMÉ 


\section{RÉSUMÉ}

Les néoplasmes myéloïdes sont un groupe hétérogène de maladies clonales de cellules souches hématopoïétiques, qui perdent la capacité de se différencier normalement et répondre aux mécanismes de réglementation normale de la prolifération. Cette perte entraîne des infections mortelles, des saignements, ou l'infiltration d'organes en l'absence de traitement. Parmi les cancers liés à des aberrations chromosomiques qui jettent un éclairage nouveau sur les origines de la néoplasie myéloïde, la famille de réarrangements du gène $M L L$ localisée dans le chromosome 11 , bande q23, se révèle être une zone fertile de recherche. Le locus MLL est impliqué dans plus de 60 différentes translocations chromosomiques avec un groupe remarquablement diversifié de partenaires de fusion, et est associée, principalement, avec des sous-types de leucémie aiguë myéloïde FAB M4 ou M5. Réarrangements du gène MLL comprennent des translocations chromosomiques, des duplications internes du gène, des délétions ou des inversions du chromosome 11q, et des insertions du gène $M L L$ en d'autres chromosomes ou vice versa.

En effet, non seulement nous avons identifier le gène de fusion MLL-SEPT2 comme l'anomalie moléculaire sous-jacente à la translocation $t(2 ; 11)(q 37 ; q 23)$ en leucémie myéloïde aiguë liée a la thérapie, et nous avons également découvert un nouvelle variante de fusion MLL-SEPT2 dans le syndrome myélodysplasique résultant de la thérapie. La présente étude a été étendue pour englober patients avec néoplasie myéloïde et fusions MLL-SEPT6 ou MLL-SEPT9, et dan ces cas, plusieurs nouvelles variantes de fusion ont été découvertes. Fait intéressant, nous avons constaté que tous les cas avec la fusion du gène MLL-SEPT2 sont des adultes avec néoplasie myéloïde, résultant du traitement chimiothérapique pour une néoplasie précédent, avec les inhibiteurs de la enzyme topoisomérase II. L'identification des sites consensus de clivage de la enzyme topoisomérase II, dans patients avec la fusion MLL-SEPT2, fournit un soutien vers un lien entre le traitement inhibiteur de la enzyme topoisomérase II et l'origine du gène de fusion MLL-SEPT2. La même signature topoisomérase II a aussi été détecté dans des patients avec le gène de fusion MLL-SEPT6, ce qui soutient l'hypothèse de que l'exposition aux inhibiteurs de la topoisomérase II peuvent entraîner des cassures des deux brins d'ADN, qui déclenchent la voie, non homologue, de correction des erreurs de $A D N$, ce qui à son tour, peut conduire à formation des oncogènes de fusion MLLSEPT2 ou MLL-SEPT6. Malgré la distribution d'âges différents (les cas MLL-SEPT2 sont des adultes et les cas MLL-SEPT6 sont des enfants), nous supposons que la cause de la origine des gènes de fusion $M L L-S E P T$ dans les deux groupes, pourrait être l'exposition à 
des inhibiteurs de l'enzyme topoisomérase II. En accord avec cette hypothèse, il y a plusieurs études qui suggèrent un lien de causalité entre la leucémie infantile induite in utero et l'exposition maternelle à des composés alimentaires qui peuvent agir comme des poisons de la enzyme topoisomérase II et l'observation de que tous les cas MLL-SEPT2 sont le résultat d'un traitement par chimiothérapie contenant inhibiteurs de l'enzyme topoisomérase II.

En autre, nous avons également constaté que dans les cancers hématologiques, des anomalies d'expression des septines peuvent être divisés en deux grands groupes: des anomalies d'expression associées à des fusions du gène $M L L$ et des anomalies d'expression pas associés avec les gènes de fusion MLL. En effet, nous avons constaté une réduction statistiquement significative de l'expression combiné du gène SEPT2 de type sauvage et du gène de fusion MLL-SEPT2 dans les cas avec la fusion du gène MLL$S E P T 2$, qui était accompagné de bas règlement de l'expression combiné du gène $M L L$ de type sauvage et du gène de fusion $M L L-S E P T 2$. Bas régulation concomitante du gène MLL e de son partenaire de fusion SEPT, a aussi été observée dans MLL-SEPT6 patients. Ces résultats suggèrent que la régulation du gène $M L L$ et de son partenaire de fusion SEPT est un événement commun dans le néoplasie myéloïde MLL-SEPT. Bas régulation de certains gènes de la famille des septines semble également être un phénomène répandu dans les néoplasies myéloïdes en l'absence des gènes de fusion $M L L$. Par exemple, nous avons constaté que la leucémie PML-RARA était clairement distincts des autres groupes de la leucémie myéloïde aiguë en ce qui concerne à des anomalies de expression des gènes des septines, car elle montre la régulation négative de neuf de ces septines (SEPT1, SEPT2, SEPT3, SEPT4, SEPT5, SEPT7, SEPT9, $S E P T 10$, et SEPT13). En autre, nous avons également observé la régulation négative de SEPT1, SEPT5, et SEPT10 dans la leucémie CBFB-MYH11, dans la leucémie RUNX1$R U N X 1 T 1$, et dans leucémies aiguës myéloïdes avec un caryotype normal. En autre, tant SEPT4 que SEPT9 ont également été montré à être sous exprimés dans toutes les sousgroupes de la leucémie aiguë myéloïde avec le exception de la leucémie CBFB-MYH11. D'autre part, des changements d'expression de SEPT8, SEPT11, et SEPT12 ne semblent pas être fréquentes dans les néoplasies myéloïdes, car ils n'ont pas été trouvés en aucun des groupes étudiés. Par opposition à la régulation négative, la régulation positive de gènes de la famille des septines dans les néoplasies hématologiques semble être un événement rare. En effet, la surexpression a été détectée seulement pour le gène SEPT6 et il a été limité à la leucémie CBFB-MYH11.

Bien qu'à ce stade des hypothèses concernant le rôle des septines dans l'oncogenèse restent pour la plupart spéculative, de leur rôle fondamental dans la cytocinèse, dans la remodelage de la membrane et dans la compartimentation cellulaire 
peuvent fournir quelques indices sur la façon dont les anomalies dans le cytosquelette des septines pourraient être impliquées dans les maladies néoplasiques. Le développement de techniques in vitro et des modèles in vivo de la leucémogenèse $M L L-$ SEPT rendrait possible une réponse à ces questions. 
SUMMARY - RESUMO - RÉSUMÉ 
